UNIVERSIDADE DE SÃO PAULO

ESCOLA DE ENGENHARIA DE SÃO CARLOS

INSTITUTO DE FÍSICA DE SÃO CARLOS

INSTITUTO DE QUÍMICA DE SÃO CARLOS

\title{
APLICAÇÃO DE PARTÍCULAS LONGAS E ORIENTADAS DE BAGAÇO DE CANA-DE-AÇÚCAR NA PRODUÇÃO DE PAINEL PARTICULADO SIMILAR AO OSB.
}

\section{ANTONIO JORGE PARGA DA SILVA}

Tese apresentada à Área de Interunidades em Ciência e Engenharia de Materiais, da Universidade de São Paulo, como parte dos requisitos para a obtenção do Título de Doutor em Ciência e Engenharia de Materiais.

Orientador: Francisco Antonio Rocco Lahr

São Carlos Dezembro/2006 
AUTORIZO A REPRODUÇÃO E DIVULGAÇÂO TOTAL OU PARCIAL DESTE

TRABALHO, POR QUALQUER MEIO CONVENCIONAL OU ELETRÔNICO, PARA FINS DE ESTUDO E PESQUISA, DESDE QUE CITADA A FONTE.

Ficha catalográfica elaborada pelo Serviço de Biblioteca e Documentação

Silva, Antonio Jorge Parga da

S586a Aplicação de partículas longas e orientadas de bagaço de cana-de-açucar na produção de painel particulado similar ao OSB / Antonio Jorge Parga da Silva. São Carlos, 2006. $167 p$.

Tese (Doutorado) Escola de Engenharia de São Carlos/ Instituto de Física de São Carlos/ Instituto de Química de São Carlos -Universidade de São Paulo, 2006.

Área: Ciência e Engenharia de Materiais.

Orientador: Prof. Dr. Francisco Antonio Rocco Lahr.

1.OSB. 2.Bagaço de cana. 3.Partículas longas. I. Título 
DEDICO ESTE TRABALHO

AOS MEUS PAIS, ANTONIO JORGE \& MARIA

HELENA...POR TODO CARINHO, INCENTIVO E AMOR QUE ME PROPORCIONAM;

A MINHA ESPOSA, CLAÚDIA FABIANY, E FILHOS, AGISLAYNE E JOÃO VICTOR, PELOS TEMPOS AUSENTES. . .

\section{Agradecimentos:}

A minha Instituição, o CEFET-MA. 
A USP/EESC/IFSC/IQSC, pelo programa de Interunidades em Ciência e Engenharia de Materiais.

Ao Professor Dr. Francisco Antonio Rocco Lahr, pela orientação, confiança, amizade e por ser justo.

Aos Professores Drs. Antonio Carlos Hernandes, Antonio Alves Dias, Carlito Calil Junior e Waldek Wladimir Bose filho, pelos ensinamentos nas disciplinas e confiança firmada durante todo o doutorado.

À FAPEMA, pelo amparo na minha pesquisa.

Ao Professor Dr. Antonio Ludovico Beraldo e a Gilmara Machado, pelas contribuições na qualificação.

À Roberta Pacheco Francisco Felipetto e ao professor Dr. Antonio Aprígio da Silva Curvelo, pelas análises de extração de sacarose no IQSC.

Ao IQSC, pelas análises de infravermelho e microscopia eletrônica de varredura (MEV).

A UNESP/IQ/Araraquara, pela análise térmica.

UNESP/Bauru, pelos ensaios mecânicos.

Ao Eduardo e Ricardo, da empresa Kehl, pela doação da resina poliuretana à base de óleo de mamona.

Ao José Francisco(ZÉ), pelos trabalhos prestados e pela amizade.

Aos colegas, Alexandre Carvalho, Fátima Nascimento, André Christóforo, Gustavo Tonoli, Elen Morales, André, Fernanda, Edna Moura, Pedro, Molina, Alexandre Miná, Pigozzo, Pletz, Mioto, Max, Jorge, Márcio, Andrés e demais alunos do LaMEM.

Aos funcionários do LaMEM que contribuíram neste trabalho.

À biblioteca da IFSC pela revisão das referências e ficha catalográfica.

À professora Ângela Cristina Pregnolato Giampedro, pela amizade e revisão do abstract e artigos.

A todos os meus irmãos e familiares em geral.

A Deus, grande “Arquiteto do Universo”. 


\section{RESUMO}

O desenvolvimento científico e tecnológico dos paises sempre é acompanhado da geração de resíduos, cujo aproveitamento reduz os problemas ambientais e proporciona novos horizontes para a sociedade. Neste trabalho foi avaliada a viabilidade técnica do emprego de partículas longas e orientadas de bagaço de canade-açúcar na confecção de painéis OSB (Oriented Strand Board), produto derivado da madeira, muito utilizado em diversos seguimentos industriais. Como adesivo, foram empregadas as resinas poliuretana à base de mamona e a resina Cascomel $\mathrm{M}$ 08 ME. Inicialmente, o bagaço de cana foi submetido a análise química para determinação das temperaturas acima das quais se processa sua degradação. $\mathrm{Na}$ continuação, foram produzidos painéis, em escala de laboratório, mantendo-se fixa a pressão de prensagem (5 MPa), variando-se a porcentagem das resinas (10 e 20\%) e a temperatura de prensagem $\left(90\right.$ e $\left.130^{\circ} \mathrm{C}\right)$, seguindo as sugestões de outros pesquisadores. Dos painéis obtidos foram retirados corpos-de-prova para determinação de propriedades físicas e mecânicas de acordo com as recomendações do documento normativo EN-300/2002, originalmente voltado para o OSB, dada a inexistência de normas especificas para painéis de partículas longas e orientadas de bagaço de cana-de-açúcar. Os resultados demonstraram a viabilidade da produção dos mencionados painéis, cujas propriedades atenderam aos requisitos das diferentes faixas de uso propostas pela norma padrão.

Palavra chave: OSB. Bagaço de cana. 


\begin{abstract}
Scientific and technological development brings togheter residues generation, which, employment reduces social and environmental problems. The aim of, this study is to demonstrate the true possibily of using long and oriented particles of sugar cane bagasse in the manufacture of panels similar to OSB (Oriented Strand Board), a wood based product widely applied in several industry segments. As adhesives were employed: polyurethane resin based on castor-oil and cascomel M $08 \mathrm{ME}$. The first step was to submit sagar cane bagasse to chemical analysis in order to determine degradation temperatures. So, in laboratory scale, panels were producted, in following conditions: fixed production pressure (5 MPa); variable resin content (10 and $20 \%$ ) and variable production temperature (90 e $130^{\circ} \mathrm{C}$ ), according to suggestions proposed by other researchers. After, specimens were obtained from the manufactured panels and tested obeying normative recommendations of EN300/2002 ( code related to OSB panels, because no specific documents concerned to sugar cane bagasse panels are available). Results demonstrated the good performance of the mentioned panels, whose properties are compatible with the proposed levels to OSB established in standard norm.
\end{abstract}

Keywords: OSB. Cane bagasse. 


\section{LISTA DE FÍGURAS}

Figura 1.1. Produção e colheita da cana-de-açúcar no Brasil.

Figura 1.2. Fibras longas para fabricação de OSB de bagaço da cana-deaçúcar.

Figura 1.3. Fluxograma morfológico da cana.

Figura 1.4. Camadas de constituição da cana. 20

Figura 1.5. Painéis OSB produzido na MASISA. 21

Figura 2.1. Queima da cana-de-açúcar para colheita. 32

Figura 2.2. Camadas orientadas, partículas longas, painéis OSB do mercado. 35

Figura 2.3. Curva de decomposição do polímero em atmosfera de $\mathrm{N}_{2}$. 44

Figura 2.4. Curva do ensaio de tração para amostra do polímero à base de poliuretano puro.

Figura 3.1. Equipamento NETZSCH, modelo STA 409 Cell de análise termogravimétrica.

Figura 3.2. Material tratado em água por 30 horas e exposto ao sol para secagem natural.

Figura 3.3. Bagaço após tratamento submetido à secagem em estufa. 52

Figura 3.4. Mini triturador para pequenas análises. 52

Figura 3.5. Balança eletrônica de ensaio do teor de umidade e do teor de sólidos.

Figura 3.6. Extração de sacarose a $100^{\circ} \mathrm{C}$.

Figura 3.7. Corte do bagaço de cana-de-açúcar para definir tamanho de partículas.

Figura 3.8. Misturador cilíndrico em aço inox e tubulação de transporte da resina.

Figura 3.9. Pistola de pintura em ar comprimido.

Figura 3.10. Vista frontal da bancada e misturador de lascas e partículas. 57

Figura 3.11. Vista lateral da bancada e misturador de lascas e partículas. 58

Figura 3.12. Desempenho do sistema cilíndrico, polias e motor no misturador. $\quad 58$

Figura 3.13. Misturador de partícula/resina desenvolvido no LaMEM. 59 
Figura 3.14. Mostra o modelo do projeto de orientador desenvolvido durante esta tese.

Figura 3.15. Orientador de partículas longas.

Figura 3.16. Camadas de partículas orientadas de bagaço de cana.

Figura 3.17. Partículas longas em Prensa hidráulica Marconi MA-98/50 e o produto final.

Figura 3.18. Equipamento de microscopia eletrônica de varredura (MEV).

Figura 3.19. Equipamento de espectroscopia de absorção em infravermelho.

Figura 3.20. Projeto do regulador de pressão desenvolvido no LaMEM. 66

Figura 3.21. Equipamento controlador de pressão hidrostática. $\quad 67$

Figura 4.1. Curva de decomposição do bagaço de cana-de-açúcar. 73

Figura 4.2. $\quad$ Espectro de infravermelho do pré-polímero, poliol, painel de partículas longas e orientadas de bagaço com 10\% resina mamona a $90^{\circ} \mathrm{C}$ e $130^{\circ} \mathrm{C}$, e partículas longas e orientadas com $20 \%$ resina mamona a $90^{\circ} \mathrm{C}$.

Figura 4.3. Micrografias da região externa do bagaço da cana-de-açúcar. 78

Figura 4.4. Micrografias da região interna do bagaço da cana-de-açúcar. $\quad 79$

Figura 4.5. Micrografias da região longitudinal do painel de partículas longas de bagaço de cana-de-açúcar, com 10\% de resina à base de mamona e prensado a quente em temperatura de $90^{\circ} \mathrm{C}$.

Figura 4.6. Micrografias da região de transição longitudinal/transversal do painel de partículas longas de bagaço de cana-de-açúcar, com $10 \%$ de resina à base de mamona e prensado a quente em temperatura de $90^{\circ} \mathrm{C}$.

Figura 4.7. Micrografias da região transversal do painel de partículas longas de bagaço de cana-de-açúcar, com 10\% de resina à base de mamona e prensado a quente em temperatura de $90^{\circ} \mathrm{C}$.

Figura 4.8. Micrografias da região longitudinal do painel de partículas longas de bagaço de cana-de-açúcar, com 10\% de resina à base de mamona e prensado a quente em temperatura de $130^{\circ} \mathrm{C}$.

Figura 4.9. Micrografias da região de transição longitudinal/transversal 
do painel de partículas longas de bagaço de cana-de-açúcar, com $10 \%$ de resina à base de mamona e prensado a quente em temperatura de $130^{\circ} \mathrm{C}$.

Figura 4.10. Micrografias da região transversal do painel de partículas longas de bagaço de cana-de-açúcar, com 10\% de resina à base de mamona e prensado a quente em temperatura de $130^{\circ} \mathrm{C}$.

Figura 4.11. Micrografias da região longitudinal do painel de partículas longas de bagaço de cana-de-açúcar, com 10\% de resina à base de Cascomel MO 08 e prensado a quente em temperatura de $130^{\circ} \mathrm{C}$.

Figura 4.12. Micrografias da região de transição longitudinal/transversal do painel de partículas longas de bagaço de cana-de-açúcar, com $10 \%$ de resina à base de Cascomel MO 08 ME e prensado a quente em temperatura de $130^{\circ} \mathrm{C}$.

Figura 4.13. Micrografias da região transversal do painel de partículas longas de bagaço de cana-de-açúcar, com $10 \%$ de resina à base de Cascomel MO 08 ME e prensado a quente em temperatura de $130^{\circ} \mathrm{C}$.

Figura 4.14. Micrografias da região longitudinal do painel de partículas longas de bagaço de cana-de-açúcar, com 20\% de resina à base de mamona e prensado a quente em temperatura de $90^{\circ} \mathrm{C}$.

Figura 4.15. Micrografias da região de transição longitudinal/transversal do painel de partículas longas de bagaço de cana-de-açúcar, com $20 \%$ de resina à base de mamona e prensado a quente em temperatura de $90^{\circ} \mathrm{C}$.

Figura 4.16. Micrografias da região transversal do painel de partículas longas de bagaço de cana-de-açúcar, com 20\% de resina à base de mamona e prensado a quente em temperatura de $90^{\circ} \mathrm{C}$.

Figura 9.01. Teste de Normalidade para densidade aparente do compósito orientado de bagaço de cana-de-açúcar, com 10\% de resina poliuretana.

Figura 9.02. Teste de Normalidade para densidade aparente do compósito 
orientado de bagaço de cana-de-açúcar, com $10 \%$ de resina poliuretana, em misturador, a $90^{\circ} \mathrm{C}$.

Figura 9.03. Teste de Normalidade para densidade aparente do compósito orientado de bagaço de cana-de-açúcar, com $10 \%$ de resina poliuretana, em misturador, a $130^{\circ} \mathrm{C}$.

Figura 9.04. Teste de Normalidade para densidade aparente do compósito orientado de bagaço de cana-de-açúcar, com 10\% de resina Cascomel M $08 \mathrm{ME}$, em misturador, a $130^{\circ} \mathrm{C}$.

Figura 9.05. Teste de Normalidade para o teor de umidade do compósito orientado de bagaço de cana, com $10 \%$ de resina poliuretana a $90^{\circ} \mathrm{C}$.

Figura 9.06. Teste de Normalidade para o teor de umidade do compósito orientado de bagaço de cana-de-açúcar, com 10\% de resina poliuretana, em misturador a $90^{\circ} \mathrm{C}$.

Figura 9.07. Teste de Normalidade para o teor de umidade do compósito orientado de bagaço de cana-de-açúcar, com 10\% de resina poliuretana, em misturador a $130^{\circ} \mathrm{C}$.

Figura 9.08. Teste de Normalidade para o teor de umidade do compósito orientado de bagaço de cana-de-açúcar, com 10\% de resina Cascomel M $08 \mathrm{ME}$, em misturador a $130^{\circ} \mathrm{C}$.

Figura 9.09. Teste de Normalidade para Inchamento em espessura 24 horas do compósito orientado de bagaço de cana-de-açúcar, com $10 \%$ de resina a $90^{\circ} \mathrm{C}$.

Figura 9.10. Teste de Normalidade para Inchamento em espessura 24 horas do compósito orientado de bagaço de cana-de-açúcar, com $10 \%$ de resina à base de mamona a $90^{\circ} \mathrm{C}$, em misturador.

Figura 9.11. $\quad$ Teste de Normalidade para Inchamento em espessura 24 horas do compósito orientado de bagaço de cana-de-açúcar, com $10 \%$ de resina à base de mamona a $130^{\circ} \mathrm{C}$, em misturador.

Figura 9.12. Teste de Normalidade para Inchamento em espessura 24 horas do compósito orientado de bagaço de cana-de-açúcar, com $10 \%$ de resina à base de Cascomel M $08 \mathrm{ME}$ a $130^{\circ} \mathrm{C}$, em misturador. 
Figura 9.13. Teste de Normalidade para Adesão interna do compósito orientado de bagaço de cana-de-açúcar, com 10\% de resina.

Figura 9.14. Teste de Normalidade para Adesão interna do compósito orientado de bagaço de cana, com $10 \%$ de resina a $90^{\circ} \mathrm{C}$, em misturador.

Figura 9.15. Teste de Normalidade para Adesão interna do compósito orientado de bagaço de cana-de-açúcar, com 10\% de resina à base de mamona a $130^{\circ} \mathrm{C}$, em misturador.

Figura 9.16. Teste de Normalidade para Adesão interna do compósito orientado de bagaço de cana-de-açúcar, com 10\% de resina à base de Cascomel M $08 \mathrm{ME}$ a $130^{\circ} \mathrm{C}$, em misturador.

Figura 9.17. Teste de Normalidade para a resistência na flexão longitudinal do compósito orientado de bagaço de cana-de-açúcar, com $10 \%$ de resina poliuretana.

Figura 9.18. Teste de Normalidade para a resistência na flexão longitudinal do compósito orientado de bagaço de cana-de-açúcar, com $10 \%$ de resina poliuretana à base de mamona, em misturador a $90^{\circ} \mathrm{C}$.

Figura 9.19. Teste de Normalidade para a resistência na flexão longitudinal do compósito orientado de bagaço de cana-de-açúcar, com $10 \%$ de resina poliuretana à base de mamona, em misturador a $130^{\circ} \mathrm{C}$.

Figura 9.20. Teste de Normalidade para a resistência na flexão longitudinal do compósito orientado de bagaço de cana-de-açúcar, com $10 \%$ de resina Cascomel M $08 \mathrm{ME}$, em misturador a $130^{\circ} \mathrm{C}$.

Figura 9.21. Teste de Normalidade para resistência na flexão transversal do compósito orientado de bagaço de cana-de-açúcar, com 10\% de resina poliuretana.

Figura 9.22. Teste de Normalidade para resistência na flexão transversal do compósito orientado de bagaço de cana-de-açúcar, com 10\% de resina poliuretana à base de mamona, em misturador a $90^{\circ} \mathrm{C}$.

Figura 9.23. Teste de Normalidade para resistência na flexão transversal do 
compósito orientado de bagaço de cana-de-açúcar, com 10\% de resina poliuretana à base de mamona, em misturador a $130^{\circ} \mathrm{C}$.

Figura 9.24. Teste de Normalidade para resistência na flexão transversal do compósito orientado de bagaço de cana-de-açúcar, com 10\% de resina Cascomel M $08 \mathrm{ME}$, em misturador a $130^{\circ} \mathrm{C}$.

Figura 9.25. Teste de Normalidade no módulo de elasticidade na flexão longitudinal do compósito orientado de bagaço de cana-deaçúcar, com $10 \%$ de resina poliuretana.

Figura 9.26. Teste de Normalidade no módulo de elasticidade na flexão longitudinal do compósito orientado de bagaço de cana-deaçúcar, com 10\% de resina poliuretana à base de mamona, em misturador a $90^{\circ} \mathrm{C}$.

Figura 9.27. Teste de Normalidade no módulo de elasticidade na flexão longitudinal do compósito orientado de bagaço de cana-deaçúcar, com 10\% de resina poliuretana à base de mamona, em misturador a $130^{\circ} \mathrm{C}$.

Figura 9.28. Teste de Normalidade no módulo de elasticidade na flexão longitudinal do compósito orientado de bagaço de cana-deaçúcar, com 10\% de resina Cascomel M 08 ME, em misturador a $130^{\circ} \mathrm{C}$.

Figura 9.29. Teste de Normalidade no módulo de elasticidade na flexão transversal do compósito orientado de bagaço de cana-deaçúcar, com $10 \%$ de resina poliuretana à base de mamona a $90^{\circ} \mathrm{C}$.

Figura 9.30. Teste de Normalidade no módulo de elasticidade na flexão transversal do compósito orientado de bagaço de cana-deaçúcar, com 10\% de resina poliuretana à base de mamona, em misturador a $90^{\circ} \mathrm{C}$.

Figura 9.31. Teste de Normalidade no módulo de elasticidade na flexão transversal do compósito orientado de bagaço de cana-deaçúcar, com $10 \%$ de resina poliuretana à base de mamona, em misturador a $130^{\circ} \mathrm{C}$. 
Figura 9.32. Teste de Normalidade no módulo de elasticidade na flexão transversal do compósito orientado de bagaço de cana-deaçúcar, com $10 \%$ de resina Cascomel M 08 ME, em misturador a $130^{\circ} \mathrm{C}$.

Figura 9.33. Teste de Normalidade na adesão interna em água fervente (ensaio cíclico) do compósito orientado de bagaço de cana-deaçúcar, com $10 \%$ de resina poliuretana à base de mamona a $90^{\circ} \mathrm{C}$.

Figura 9.34. Teste de Normalidade na adesão interna em água fervente (ensaio cíclico) do compósito orientado de bagaço de cana-deaçúcar, com $10 \%$ de resina poliuretana à base de mamona, em misturador a $90^{\circ} \mathrm{C}$.

Figura 9.35. Teste de Normalidade na adesão interna em água fervente (ensaio cíclico) do compósito orientado de bagaço de cana-deaçúcar, com $10 \%$ de resina poliuretana à base de mamona, em misturador a $130^{\circ} \mathrm{C}$.

Figura 9.36. Teste de Normalidade na adesão interna em água fervente (ensaio cíclico) do compósito orientado de bagaço de cana-deaçúcar, com 10\% de resina Cascomel M 08 ME, em misturador a $130^{\circ} \mathrm{C}$.

Figura 9.37. $\quad$ Teste de Normalidade para densidade aparente do compósito orientado de bagaço de cana-de-açúcar, com 20\% de resina poliuretana à base de mamona.

Figura 9.38. Teste de Normalidade para o teor de umidade do compósito orientado de bagaço de cana-de-açúcar, com 20\% de resina poliuretana à base de mamona.

Figura 9.39. Teste de Normalidade para Inchamento em espessura 24 horas do compósito orientado de bagaço de cana-de-açúcar, com $20 \%$ de resina poliuretana à base de mamona.

Figura 9.40. Teste de Normalidade para Adesão interna do compósito orientado de bagaço de cana-de-açúcar, com 20\% de resina poliuretana à base de mamona.

Figura 9.41. Teste de Normalidade para a resistência na flexão longitudinal 
do compósito orientado de bagaço de cana-de-açúcar, com $20 \%$ de resina poliuretana à base de mamona.

Figura 9.42. Teste de Normalidade para resistência na flexão transversal do compósito orientado de bagaço de cana-de-açúcar, com 20\% de resina poliuretana à base de mamona.

Figura 9.43. Teste de Normalidade para o Módulo de elasticidade na flexão longitudinal do compósito orientado de bagaço de cana-deaçúcar, com 20\% de resina poliuretana à base de mamona.

Figura 9.44. Teste de Normalidade para o Módulo de elasticidade na flexão transversal do compósito orientado de bagaço de cana-deaçúcar com 20\% de resina poliuretana à base de mamona.

Figura 9.45. Teste de Normalidade na adesão interna em água fervente (ensaio cíclico) do compósito orientado de bagaço de cana-deaçúcar, com 20\% de resina poliuretana à base de mamona.

Figura 10.1. Bagaço de cana exposto próximo a moenda e em tanque para tratamento com água

Figura 10.2. Bagaço de cana disposto em secagem natural e em estufa a $60^{\circ} \mathrm{C}$

Figura 10.3. Partículas longas de bagaço de cana e preparo da resina a base de mamona para fabricação dos painéis

Figura 10.4 Preparo e confecção do colchão em camadas de partículas longas orientadas

Figura 10.5 Painel confeccionado a $200^{\circ} \mathrm{C}$ com fragmentos de inicio de queima e a direita o painel a $90^{\circ} \mathrm{C}$, com características adequadas para confecção tipo OSB

Figura 10.6 Painel após prensagem a quente com chapas teflonadas e serrado na borda, dando acabamento

Figura 10.7 Painéis prontos para estocagem para cura

Figura 10.8 Vista em relevo do painel e vista de topo

Figura 10.9 Painéis fabricados com vista arquitetônica

Figura 10.10 Painéis prensados em uma temperatura de $90^{\circ} \mathrm{C}$ e a direita a $130^{\circ} \mathrm{C}$

Figura 10.11 Vista de topo e lateral do painel de partículas longas de 
bagaço de cana

Figura 10.12 Painel a $130^{\circ}$ e confeccionados com resina a base de mamona e a direita, com resina a base de Cascomel M $08 \mathrm{ME}$ 163

Figura 10.13 Painéis a $130^{\circ} \mathrm{C}$ 163

Figura 10.14 Painéis prensados a $130^{\circ} \mathrm{C}$ e a $90^{\circ} \mathrm{C}$

Figura 10.15 Inicio do ensaio de resistência à flexão na direção transversal as partículas longas

Figura 10.16 Término do ensaio de resistência à flexão na direção transversal as partículas longas

Figura 10.17 Corpos-de-prova submetidos ao ensaio de inchamento em espessura e secagem em estufa

Figura 10.18 Corpos-de-prova lixados e sendo preparados para ensaios de acordo com norma EN 300/2002

Figura 10.19 Corpos-de-prova prontos para ensaio de adesão interna e painel OSB de fabrica

Figura 10.20 Ensaio de adesão interna com inicio de rompimento e a direita rompido

Figura 10.21 Visualizando face interna de corpos-de-prova de compósito de bagaço de cana de painéis rompidos por adesão interna, comparando com OSB de mercado

Figura 10.22 Preparando corpo-de-prova para ensaio e a direita painel de partículas longas de bagaço de cana-de-açúcar definitivo 


\section{LISTA DE TABELAS}

Tabela 1.1. Fonte da Organização das Nações Unidas para Agricultura e Alimentação e Instituto Brasileiro de Geografia e Estatística IBGE em 2004(www.investimentos.sp.gov.br/sis). 18

Tabela 4.01. Teor de umidade e densidade do compósito de bagaço de cana com $10 \%$ de resina.

Tabela 4.02. Teor de umidade e densidade do compósito de bagaço de cana com $20 \%$ de resina à base de mamona.

Tabela 4.03. Teor de umidade e densidade do painel de partículas longas e orientadas de bagaço de cana a $90^{\circ} \mathrm{C}$ com $10 \%$ de resina à base de mamona, em misturador.

Tabela 4.04. Teor de umidade e densidade do painel de partículas longas e orientadas de bagaço de cana a $130^{\circ} \mathrm{C}$ com $10 \%$ de resina à base de mamona, em misturador.

Tabela 4.05. Teor de umidade e densidade do painel de partículas longas e orientadas de bagaço de cana a $130^{\circ} \mathrm{C}$ com $10 \%$ de resina Cascomel M 08 ME, em misturador.

Tabela 4.06. Valores de inchamento em espessura por 24 horas com 10\% de resina à base de mamona.

Tabela 4.07. Valores de inchamento em espessura por 24 horas para o painel com $20 \%$ de resina à base de mamona a $90^{\circ} \mathrm{C}$.

Tabela 4.08. Valores de inchamento em espessura por 24 horas para o painel com $10 \%$ de resina à base de mamona a $90^{\circ} \mathrm{C}$, em misturador.

Tabela 4.09. Valores de inchamento em espessura por 24 horas para o painel com $10 \%$ de resina à base de mamona a $130^{\circ} \mathrm{C}$, em misturador.

Tabela 4.10. Valores de inchamento em espessura por 24 horas para o painel com $10 \%$ de resina à base de Cascomel M $08 \mathrm{ME}$, à temperatura de $130^{\circ} \mathrm{C}$, em misturador.

Tabela 4.11. Valores da adesão interna do painel de bagaço de cana com $10 \%$ de resina à base de mamona a $90^{\circ} \mathrm{C}$.

Tabela 4.12. Valores da adesão interna do painel de bagaço de cana com $10 \%$ de resina à base de mamona, em misturador a temperatura 
de $90^{\circ} \mathrm{C}$.

Tabela 4.13. Valores da adesão interna do painel de bagaço de cana com $10 \%$ de resina à base de mamona, em misturador a temperatura de $130^{\circ} \mathrm{C}$.

Tabela 4.14. Valores da adesão interna do painel de bagaço de cana com $10 \%$ de resina à base de Cascomel M $08 \mathrm{ME}$, em misturador e prensado à temperatura de $130^{\circ} \mathrm{C}$.

Tabela 4.15. Valores da adesão interna do painel de bagaço de cana com $20 \%$ de resina à base de mamona a $90^{\circ} \mathrm{C}$.

Tabela 4.16. Valores da adesão interna do painel após ensaio em água fervente para $10 \%$ de resina à base de mamona com temperatura de $90^{\circ} \mathrm{C}$.

Tabela 4.17. Valores da adesão interna do painel após ensaio em água fervente para $10 \%$ de resina à base de mamona, em misturador a $90^{\circ} \mathrm{C}$.

Tabela 4.18. Valores da adesão interna do painel após ensaio em água fervente para $10 \%$ de resina à base de mamona, com temperatura a $130^{\circ} \mathrm{C}$, em misturador.

Tabela 4.19. Valores da adesão interna do painel após ensaio em água fervente para $10 \%$ de resina à base de Cascomel M $08 \mathrm{ME}$, com temperatura a $130^{\circ} \mathrm{C}$, em misturador.

Tabela 4.20. Valores da adesão interna do painel após ensaio em água fervente para $20 \%$ de resina à base de mamona.

Tabela 4.21. Módulo de Elasticidade e Resistência na flexão na direção longitudinal com $10 \%$ de resina a $90^{\circ} \mathrm{C}$.

Tabela 4.22. Módulo de Elasticidade e Módulo de Resistência na flexão na direção longitudinal com $10 \%$ de resina à base de mamona à temperatura de $90^{\circ} \mathrm{C}$ em misturador.

Tabela 4.23. Módulo de Elasticidade e Módulo de Resistência na flexão na direção longitudinal com $10 \%$ de resina à base de mamona à temperatura de $130^{\circ} \mathrm{C}$.

Tabela 4.24. Módulo de Elasticidade e Resistência na flexão na direção longitudinal com $10 \%$ de resina à base de Cascomel M $08 \mathrm{ME}$ 
a temperatura de $130^{\circ} \mathrm{C}$.

Tabela 4.25. Módulo de Elasticidade e Módulo de Resistência na Flexão na direção longitudinal com $20 \%$ de resina à base de mamona a $90^{\circ} \mathrm{C}$.

Tabela 4.26. MOR e MOE na direção transversal do painel com $10 \%$ de resina à base de mamona a $90^{\circ} \mathrm{C}$.

Tabela 4.27. Módulo de Elasticidade e Resistência á flexão na direção transversal com $20 \%$ de resina à base de mamona a $90^{\circ} \mathrm{C}$.

Tabela 4.28. MOR e MOE na direção transversal com 10\% de resina à base de mamona à temperatura de $90^{\circ} \mathrm{C}$, em misturador.

Tabela 4.29. Módulo de Elasticidade e Resistência na flexão na direção transversal com $10 \%$ de resina à base de mamona à temperatura de $130^{\circ} \mathrm{C}$ em misturador.

Tabela 4.30. MOR e MOE na direção transversal com 10\% de resina Cascomel M $08 \mathrm{ME}$ à temperatura de $130^{\circ} \mathrm{C}$, em misturador.

Tabela 4.31. Propriedades dos painéis de partículas longas e orientadas de bagaço de cana-de-açúcar em relação ao documento normalizado EN-300/2002.

Tabela 8.1. Painéis para usos gerais, incluindo mobiliário, interiores, utilizados em ambiente seco.

Tabela 8.2. Painéis para fins estruturais utilizados em ambiente seco, requisitos para as propriedades mecânicas e de inchamento.

Tabela 8.3. Painéis para fins estruturais utilizados em ambiente úmido Requisitos para as propriedades mecânicas e de inchamento.

Tabela 8.4. Painéis para fins estruturais especiais utilizados em ambiente úmido - Requisito para as propriedades mecânicas e de inchamento. 


\section{SUMÁRIO}

1. INTRODUÇÃO 15

1.1. Generalidades a respeito do bagaço de cana de açúcar 15

1.2. Generalidades a respeito do OSB 21

1.3. Resina 23

1.4. Protocolo de Kyoto 24

1.5. Objetivos 25

1.5.1. Objetivo geral 25

1.5.2. Objetivos específicos 25

2. REVISÃO BIBLIOGRÁFICA 27

$\begin{array}{ll}\text { 2.1. Bagaço de cana } & 27\end{array}$

2.2. OSB “Oriented Strand Board” 33

2.3. A resina 40

2.4 Protocolo de Kyoto 46

3. MATERIAIS E MÉTODOS 48

3.1. Materiais 48

3.2. Métodos 50

3.2.1. Termogravimetria (TG) e Análise Térmica Diferencial (DTA) 50

3.2.2. Tratamento 51

3.2.3. Secagem 51

3.2.4. Extração com água

3.2.5. Mistura 55

3.2.6. Orientador de partículas $\quad 59$

$\begin{array}{ll}\text { 3.2.7. Prensagem } & 60\end{array}$

3.2.8. Microscopia eletrônica de varredura (MEV) 62

3.2.9. Espectroscopia de absorção na região de infravermelho 63

3.3. Propriedades mecânicas e físicas 64

3.3.1. Ensaio para determinação da umidade EN-322/2000 64

3.3.2. Ensaio para a determinação da densidade EN-323/2000 65

3.3.3. Ensaio de inchamento em espessura por 24 horas 66

3.3.4. Adesão interna pela EN-319/1993 67 
3.3.5. Ensaio de adesão interna em água fervente 68

3.3.6. Ensaio na flexão para MOR e MOE 69

4. RESULTADOS E DISCUSSÃO 72

4.1. Características térmicas 72

4.2. Espectroscopia de absorção na região do infravermelho 75

4.3. Microscopia eletrônica de varredura 77

4.4. Teor de umidade e densidade $\quad 92$

4.5. Inchamento em espessura 24 horas 97

4.6. Adesão interna 102

4.7. Adesão interna em água fervente (Ensaio cíclico) 107

4.8. Módulo de Elasticidade e Módulo de Resistência na Flexão 112

4.9. Teste de Normalidade 123

5. CONCLUSÕES 124

6. RECOMENDAÇÕES PARA TRABALHOS FUTUROS 126

7. REFERENCIAS 127

8. ANEXO A 132

9. ANEXO B 135

10. ANEXO C 159

11. APÊNDICE 167 


\section{INTRODUÇÃO}

Serão abordadas algumas generalidades do bagaço da cana-de-açúcar, da produção de chapas de partículas OSB a nível mundial, focalizando sua chegada ao Brasil e o desenvolvimento da resina poliuretana à base de mamona.

\subsection{Generalidades a respeito do bagaço de cana de açúcar}

As expectativas de avanços tecnológicos e científicos para surgimento de novos materiais, destacando-se o emprego de resíduos oriundos ou relacionados a agroindústrias e indústrias, que podem ser utilizados como matéria-prima no processo de produção de um novo material. O aproveitamento e reciclagem dos resíduos diminuem os problemas ambientais e sociais, minimizando o uso de material de alto valor nobre.

A reciclagem também torna mais úteis e aproveitáveis as matérias primas como o bagaço da cana-de-açúcar (Saccharum officinarum) e outros materiais alternativos, de grande interesse tecnológico e científico na solução dos problemas de impactos da atualidade. 
O reaproveitamento dos resíduos de fibras naturais para obtenção de um produto de utilidade vem sendo uma prática de grande interesse e que gera uma série de vantagens nas áreas sociais.

Esses interesses ampliam patamares de aplicações econômicas de novos materiais com intenção de obter um produto de baixo custo, ecologicamente prudente e com menor poder poluente, contribuindo para o desenvolvimento sustentável de um país. Impactos ambientais são gerados por impactos ecológicos, sociais e econômicos, simultaneamente, e podem ser evitados de acordo com o grau de aceitação de uma política de pesquisa voltada para esses objetivos.

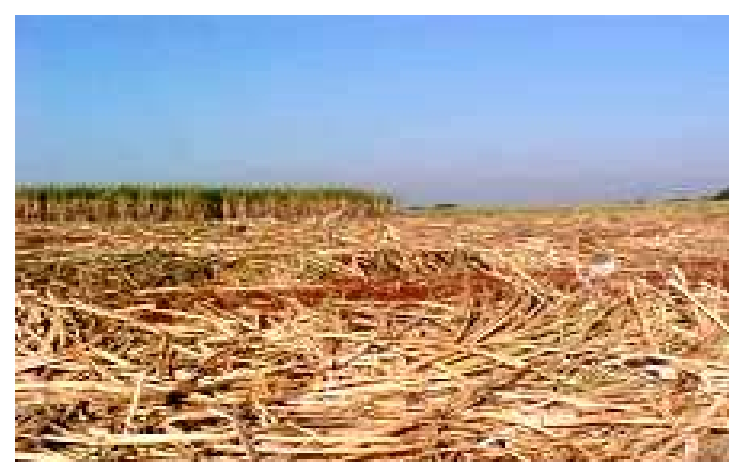

Figura 1.1. Produção e colheita da cana-de-açúcar no Brasil

Os compósitos de fibras naturais são produtos conhecidos em diversas partes do mundo. Entretanto, no Brasil, sua utilização ainda é relativamente restrita, em conseqüência da falta de políticas de expansão científica e exploração de informações a respeito de suas estruturas e propriedades, para sustentar estudos de reaproveitamento e continuidade dos projetos de pesquisas, enfatizando determinado material e produto. As fibras lignocelulósicas possuem a vantagem de apresentar elevada relação entre comprimento e espessura que contribui no processo de fabricação para painéis de OSB.

A cana-de-açúcar (Figura 1.1) possui uma quantidade considerada de fibras lignocelulósicas e longas, com tamanhos variando de 3cm até, aproximadamente, uns 
20cm de comprimento, o que se caracteriza como sendo de vital importância para projetos de pesquisa com resíduos derivados de matéria orgânica desta natureza, onde este resíduo possa ser utilizado sem perdas de qualidades das fibras compostas por esta matéria prima. Nos processos de colheita e processamento da cana-de-açúcar para obtenção de seus derivados, é produzida uma grande quantidade de resíduos em forma de bagaço, oriundos das moendas.

No processo já existente, há uma desqualificação da estrutura da fibra, obtendo-se fibras pequenas, curtas e com baixas propriedades físicas e mecânicas.

Essas fibras, depois de trituradas em moendas, têm um baixo valor de reutilização, sem que haja transformação em um produto satisfatório, pois, atualmente, o resíduo vem sendo usado na usina para queima e geração de energia.

Adquirir fibras longas (Figura 1.2) é o desafio que constitui objetivamente o presente estudo. Pensando em dar um maior valor agregado e econômico, com fácil aplicabilidade, para este resíduo, é que desenvolvemos este produto de alta utilização ampliando os recursos disponíveis para particulados de fibras longas e orientadas, dando abertura a mudanças no aspecto tecnológico, até com uma possível mudança nos equipamentos industriais disponíveis nas usinas, viabilizando um modelo de produção de bagaço em partículas com fibras longas, como mais uma opção de aplicação desta matéria prima. 


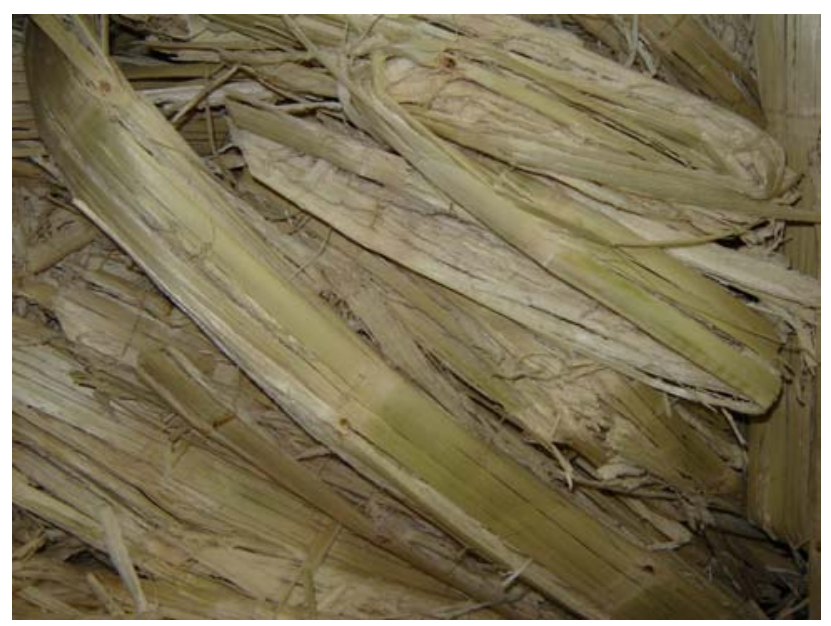

Figura 1.2. Fibras longas para fabricação de OSB de bagaço da cana-de-açúcar

O avanço em novas tecnologias traz mudanças na obtenção de um produto final diferente e alternativo, obtendo com isso novos modelos de materiais que precisam ser colocados em prática na obrigação de modificar a política de produções industriais e alcançar uma política científica, econômica e ecologicamente satisfatória. Os maiores produtores mundiais de cana-de-açúcar, de acordo com informações até o ano de 2004, estão mostrados na tabela 1.1.

Tabela 1.1- Fonte da Organização das Nações Unidas para Agricultura e Alimentação e Instituto Brasileiro de Geografia e Estatística - IBGE (www.investimentos.sp.gov.br/sis).

\begin{tabular}{|c|c|}
\hline Países & $\begin{array}{c}\text { Produção(em mil } \\
\text { toneladas) }\end{array}$ \\
\hline Filipinas & 28.000 \\
Austrália & 36.892 \\
Colômbia & 37.100 \\
México & 45.127 \\
Paquistão & 52.040 \\
Tailândia & 63.707 \\
China & 93.200 \\
Índia & 244.800 \\
Brasil & 416.256 \\
\hline
\end{tabular}


No Brasil, a produção de açúcar e álcool gera bagaço da cana como subproduto ou resíduo. Após a separação da garapa ou caldo de cana, da qual são produzidos o açúcar, o álcool e outros produtos, sobra o resíduo denominado bagaço de cana-deaçúcar. Atualmente este bagaço é queimado para geração de energia, em parte para a própria usina e, em parte, para ser usada ou vendida para cidades próximas. Como o Brasil é o maior produtor mundial de cana-de-açúcar, os resíduos derivados deste produto estão na mesma proporção percentual de produção e a utilização dos componentes dessa biomassa vegetal é de grande importância econômica e ambiental. Abaixo é mostrado um fluxograma morfológico da cana-de-açúcar (Figura 1.3).

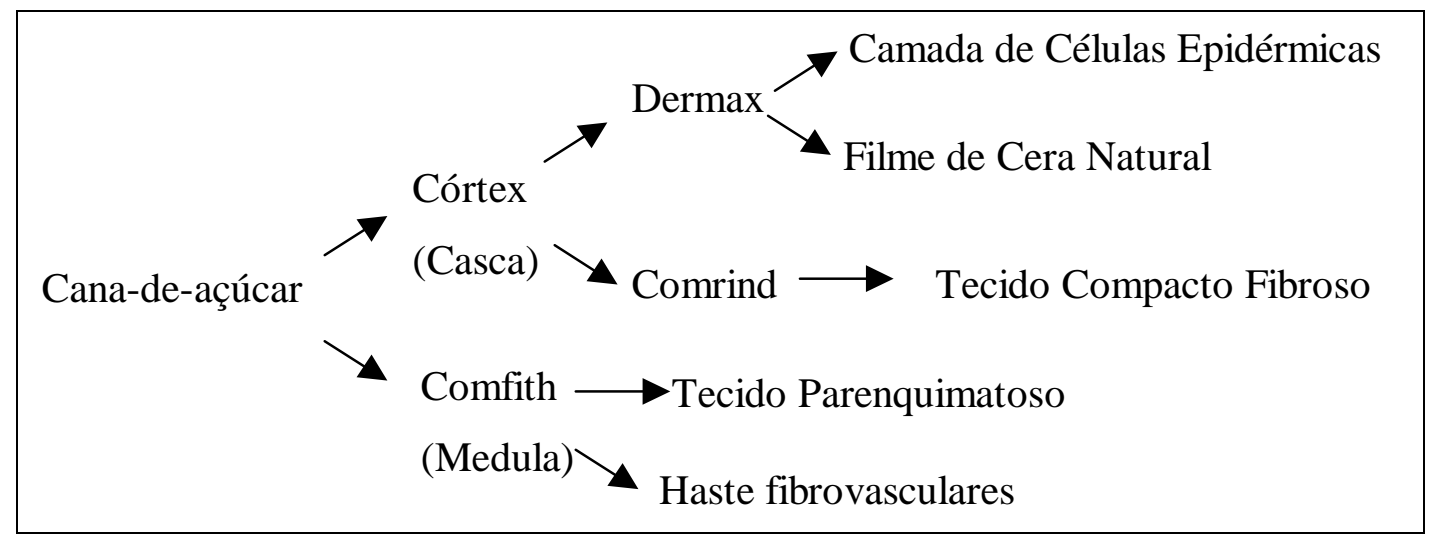

Figura 1.3. Fluxograma morfológico da cana

A figura 1.4 mostra a localização das camadas de constituição da cana-de-açúcar. 


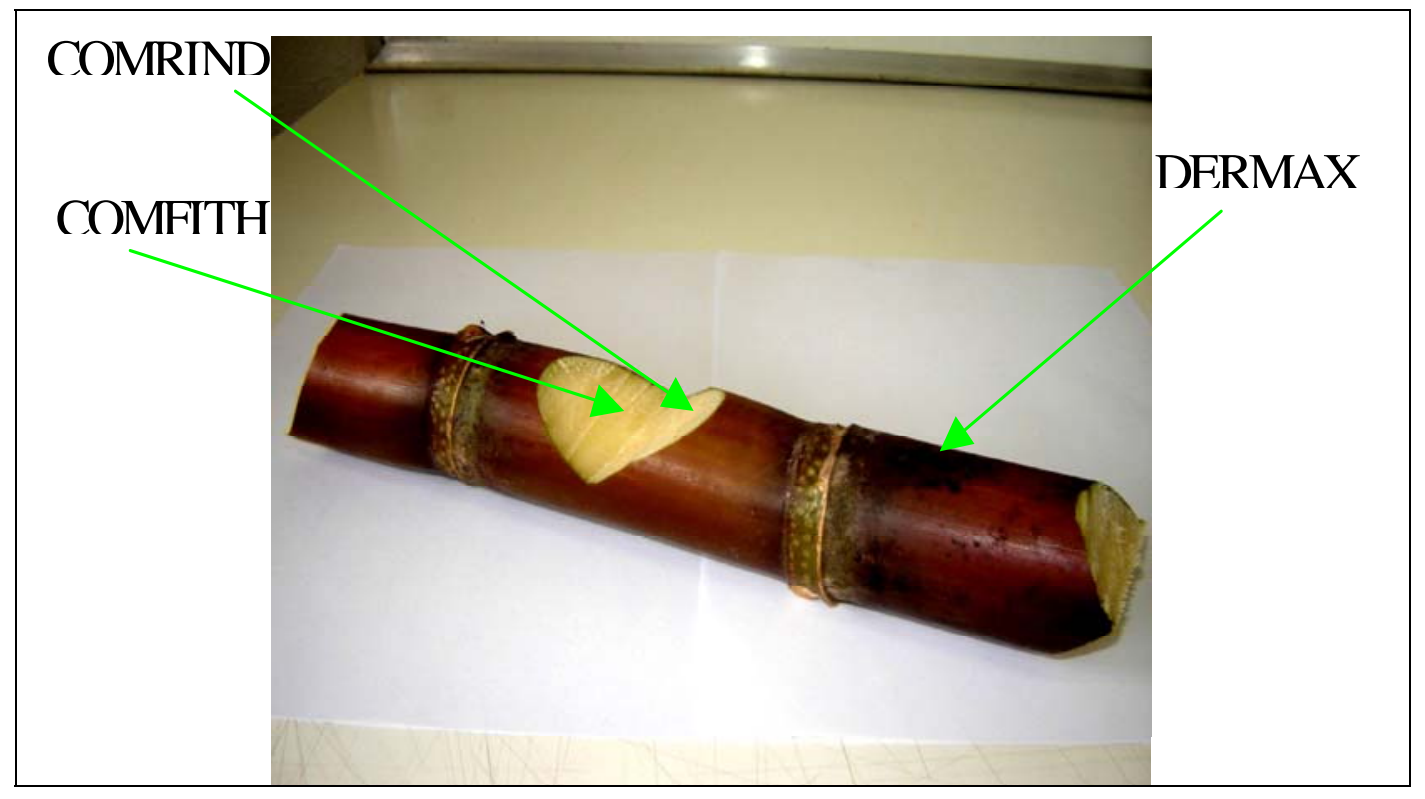

Figura 1.4. Camadas de constituição da cana

A cana-de-açúcar morfologicamente é constituída de “córtex” ou casca e “comfith” ou medula. O “córtex” está localizado na parte mais externa, sendo composto pelo “dermax” e pelo “comrind”: no “dermax”, região mais externa, estão presentes o filme de cera natural semelhante à cera de carnaúba e a camada de células epidérmicas que é a região de formação da cor da cana; a região mais interna do “córtex” é o “comrind” ou casca dura, que é representado pelo tecido compacto fibroso, onde as fibras estão mais unidas e bem compactadas, dando um aspecto estrutural com grande resistência para sustentação do caule da cana-de-açúcar.

Dentro do “córtex” está o “comfith” ou medula, região representada pelo tecido parenquimatoso, composto de fibras espalhadas e haste fibrovascular. O “comfith”, em forma de resíduo, apresenta uma densidade muito baixa, devido à distribuição de fibras e tecido parenquimatoso.

O estudo de desenvolvimento de materiais derivados da cana-de-açúcar ou, mais precisamente, do resíduo é de grande valia para o mundo, considerando-se que é um produto com matéria-prima em excesso e que influencia o meio ambiente. 


\subsection{Generalidades a respeito do OSB}

A produção em escala industrial de chapas estruturais de partículas teve início na década de 1970, nos Estados Unidos, com a denominação comercial de “waferboard”. As chapas eram produzidas com partículas de dimensões maiores, em relação às partículas utilizadas nos aglomerados “convencionais”, porém com a mesma distribuição aleatória no processo de formação do colchão.

A partir de meados da década de 1970 , surgiu o produto considerado de $2^{\text {a }}$ geração de chapas estruturais, denominado comercialmente de "Oriented Strand Board OSB”. Desde então, houve uma grande expansão na produção e utilização de chapas “OSB”, alcançando fronteiras além dos Estados Unidos e Canadá. No Brasil, a primeira unidade industrial entrou em operação no ano de 2002 e o produto começou a ser difundido como painel estrutural de usos múltiplos.

O OSB em geral é um painel estrutural de tiras de madeira (Figura 1.5), distribuídas em forma de camadas cruzadas, para aumentar sua estabilidade e resistência, unidas entre si por resina fenólica aplicada sob alta pressão e temperatura.

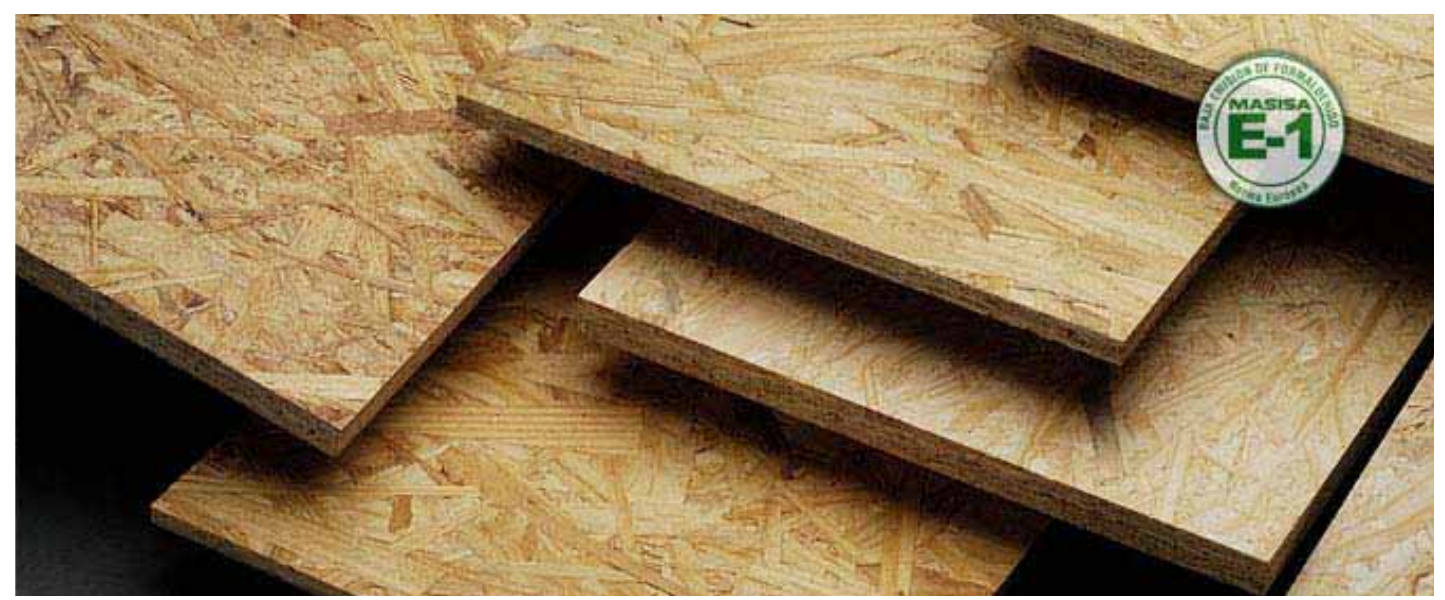

Figura 1.5. Painéis OSB produzido na MASISA

O OSB tem tido muita aceitação para vários usos por ser considerado um excelente produto de construção e acabamento. Dentre seus atributos, pode-se destacar sua 
resistência mecânica, rigidez, propriedades isolantes, capacidade para absorver diferentes solicitações e um design diferenciado.

O painel OSB oferece resistência para múltiplos usos e tem uma ampla aplicação no ramo da construção de moradias, em todos os tipos existentes, e outras aplicações, dentre as quais se destacam: pisos, paredes, vigas I, escadas, forros, coberturas, tapumes, barracões, bandejas de proteção. Outras aplicações: móveis, alto-falantes, divisórias, embalagens (Bins e Paillets), acabamento em geral e design, conforme citações da Revista da madeira, ano 16, nº 97, Junho/2006.

A utilização de chapas “OSB” tem aumentado e vem ocupando espaço antes exclusivo de compensados, em virtude de fatores como:

- redução da disponibilidade de toras de boa qualidade para laminação;

- produção partindo de toras de qualidade inferior e de espécies de baixo valor comercial;

A largura e o comprimento das chapas “OSB” são determinados pela tecnologia de produção e não em função do comprimento das toras, como no caso de compensados. O contexto atual do setor florestal brasileiro demonstra os reflexos da exploração predatória das florestas naturais, causada, principalmente, pela expansão da fronteira agropecuária, pelas atividades de mineração, pela produção de carvão vegetal e outras. A falta de uma política de monitoramento da exploração, via manejo sustentado, também contribuiu para agravar a situação. Dentro deste contexto parece, cada vez mais, que a tendência lógica consiste na utilização de madeira reconstituída da indústria moveleira e de materiais alternativos de fibras lignocelulósicas.

Por ser um produto recentemente produzido no Brasil, pode-se considerar que são poucas as informações disponíveis no mercado sobre as variáveis de seu 
processamento, principalmente com relação a materiais alternativos ainda não explorados no processo de produção.

\subsection{Resina}

As reações de condensação, propostas por Wurtz em 1849, são o produto da reação química entre um grupo isocianato e um grupo hidroxila, como mostra a equação 1.1.

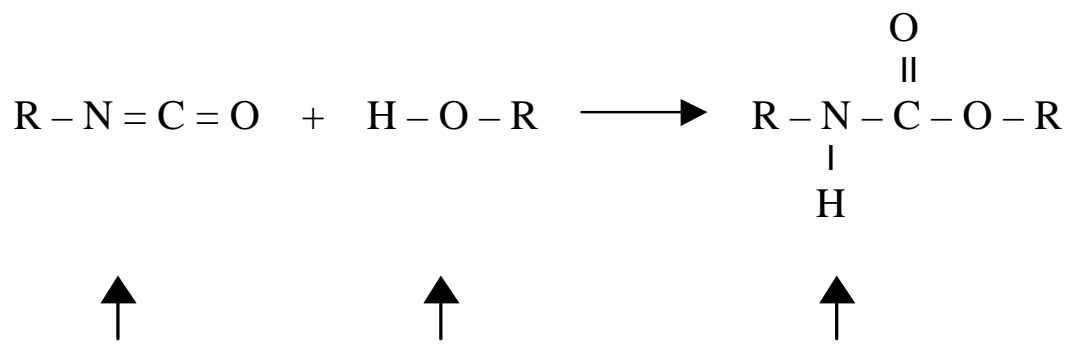

Isocianato Hidroxila Uretana

Esta reação só teve aplicação comercial nas décadas de 1930 e 1940, com o desenvolvimento, por BAYER, dos primeiros polímeros poliuretanos.

A tendência mundial em busca de materiais naturais biodegradáveis, derivados de biomassa, levou a optar pela resina poliuretana, derivada de óleo de mamona, nesta pesquisa.

Desde 1984, o Grupo de Química Analítica e Tecnologia de Polímeros - USP - São Carlos - SP desenvolve pesquisas com polímeros poliuretanos derivados de óleo de mamona e, neste período de 22 anos, adquiriu tecnologia para os mais variados ramos da indústria.

Uma resina em parte natural, com dois componentes (poliol à base de mamona e prépolímero da Bayer à base de derivado do petróleo), na proporção de 1(prépolímero)/2(poliol), que foi desenvolvida no IQSC/USP/BR, à base de óleo de mamona, de classificação impermeável, não-agressiva ao meio ambiente e ao ser 
humano por não emitir gases, será a alternativa proposta neste trabalho, até porque existe uma continuidade de estudo no grupo de derivados de madeiras e materiais alternativos da EESC/LaMEM ligado a Interunidades em Ciência e Engenharia de Materiais.

No processo de obtenção do OSB de partículas longas de bagaço de cana-de-açúcar, utilizam-se resinas para impregnar. O painel é obtido obedecendo a padrões da norma EN-300/2002 e utilizando resina à base de óleo de mamona, processada à temperatura de $90^{\circ} \mathrm{C}$ e $130^{\circ} \mathrm{C}$, observando suas vantagens relacionadas ao processo normalizado, onde as resinas são processadas a temperaturas elevadas e superiores a $130^{\circ} \mathrm{C}$, supondo ocasionar um maior custo de energia na linha de produção.

Resinas à base de uréia apresentam perda de resistência na ação de umidade em um curto tempo e, no processo de prensagem, elas provocam emissão de formaldeído que é nocivo à saúde. Há países onde o controle ambiental é na atualidade, quase unânime.

Análises finais verificaram uma tendência de uso dessa resina em temperaturas desde $90^{\circ} \mathrm{C}$ até $130^{\circ} \mathrm{C}$, com ganhos de resistência para aplicação no processo de OSB de bagaço da cana-de-açúcar. Após análises físicas e mecânicas, descobriu-se um novo material alternativo com características de OSB, de valor econômico, social, ambiental, científico e tecnológico.

Este novo material alternativo torna-se viável com características de potencial para aplicação como OSB, o qual será em tese dissertado no decorrer deste trabalho.

\subsection{Generalidade do Protocolo de Kyoto}

O Protocolo de Kyoto é um acordo para a negociação de cotas certificadas de carbono que também se torna vantajosa para o país, graças à anexação ao Protocolo 
de Kyoto dos “Mecanismos de Desenvolvimento Limpo”, permitindo que os países que não constam deste Protocolo, negociem taxas de carbono com os países que não conseguirem atingir as metas estabelecidas.

O setor produtivo depende, direto ou indiretamente, do ambiente como fonte de matérias-primas primárias para o seu desenvolvimento, bem como da utilização de alguns locais para “área de despejo” de seus subprodutos e resíduos gerados durante o seu ciclo produtivo. Essa eliminação de rejeitos, quando quantificada, controlada e tratada, torna-se facilmente passível de depuração pelo ambiente em determinado tempo. Caso contrário, a sua depuração pode levar milhares de anos ou, até mesmo, deixar de ocorrer, pela ausência de mecanismos específicos de depuração pela natureza.

\subsection{Objetivos}

Neste item são apresentados os objetivos mais relevantes do presente trabalho.

\subsubsection{Objetivo geral}

Considera-se objetivo geral evidenciar a viabilidade técnica da fabricação, em escala de laboratório, de painéis particulados similares ao OSB (Oriented Strand Board), derivado da madeira utilizando como insumo o bagaço de cana, resíduo originário do processamento da Saccharum officinarum, nas usinas de produção de açúcar e álcool.

\subsubsection{Objetivos específicos}

Como objetivos específicos têm-se:

- Demonstrar que o bagaço de cana não sofre degradação térmica nos níveis de temperatura usualmente empregados na produção de painéis particulados; 
- demonstrar que a resina poliuretana à base de mamona e a resina Cascomel $\mathrm{M}$ 08 ME são compatíveis com o bagaço de cana para a produção de painéis de partículas longas e orientadas;

- demonstrar que os painéis particulados de bagaço de cana, produzidos com as resinas mencionadas, em níveis usuais de temperatura e pressão empregados na indústria de derivados da madeira, podem atingir propriedades físicas e mecânicas de mesma ordem de grandeza dos painéis OSB;

- Demonstrar que as variáveis: temperatura de prensagem, orientação de partículas e teor de resina em relação ao bagaço de cana influem nas propriedades físicas e mecânicas dos painéis particulados produzidos. 


\section{REVISÃO BIBLIOGRÁFICA}

Nesta etapa será abordada algumas pesquisas realizadas com o bagaço de cana-deaçúcar, com o OSB, a resina e a importância do protocolo de Kyoto.

\subsection{Bagaço de Cana}

O bagaço de cana-de-açúcar ainda é um resíduo de baixa exploração no Brasil, composto de fibras, medula e de partículas finas e materiais solúveis. De acordo com (SANTANA, TEIXEIRA, 1993), quimicamente, o bagaço “in natura” é composto por $44,5 \%$ de fibras lignocelulósicas, $50 \%$ de umidade, $2,5 \%$ de sólidos solúveis em água e 3,0\% de teor de cinza, o que implica em alterações, na fase inicial da industrialização do bagaço, que, na sua concepção, devem ser promovidas com o objetivo de separar a medula da fração fibrosa, para a confecção de chapas de fibras e de aglomerados. Um material sem separação da medula da fração fibrosa e de grandes propriedades físicas e mecânicas é esperado para reduzir o tempo de processo de fabricação e custo.

(SANTANA, TEIXEIRA, 1993) também verificaram que, morfologicamente, o bagaço possui $50 \%$ de fibras, $30 \%$ de tecidos parenquimatosos e $20 \%$ de elementos de vasos e epiderme. Foi realizada uma análise microscópica durante a obtenção de polpa celulósica visando observar não só a degradação física na moagem da cana na 
indústria, mas também os processos de deslignificação que degradariam mais as fibras celulósicas. Observou-se que, no bagaço “in natura”, as fibras são compactadas e, após pré-tratamento, há a descompactação, tornando-as menos resistentes à difusão de reagentes na deslignificação. Na análise morfológica evidencia-se que, no processo de pré-tratamento, o ácido utilizado não degrada as fibras celulósicas e facilita a remoção da lignina. Conclui-se que o bagaço de cana apresenta propriedades desejáveis para modificação química na obtenção de compostos de interesses econômicos. Com base nestas informações, verificou-se a importância de explorar também as características de resistências do bagaço, sem perdas e sem separação de matéria, dando uma melhor aplicabilidade ao produto e reduzindo custo de fabricação, pois não fica claro o resultado do potencial desta matéria-prima que é pouco valorizada em suas características naturais.

No presente trabalho, o bagaço será constituído de medula, material fibroso e lignina, não levando em consideração as separações morfológicas, excluindo apenas a matéria relacionada à parte líquida, tais como umidade e resíduos de sacarose.

O bagaço é o resíduo restante quando a cana-de-açúcar é submetida à pressão para extrair o açúcar. Uma grande parte do bagaço é queimada para fornecer o calor e transformar em alta energia necessária à operação nas usinas de açúcar; outra parte é retornada aos campos. De acordo com Moacir José C. P. de Almeida, consultor da Lazzarine Ambiental, a experiência cubana no desenvolvimento dos derivados empregou o bagaço de cana triturado na fabricação de papel e na confecção de placas aglomeradas (JORNALCANA, 1999).

O bagaço é composto macroscopicamente de fibra e medula. A fibra, ao ser triturada, tem sua resistência afetada e seu comprimento é alterado ficando em torno de 1 a 
4mm, devido ao processo de extração da parte líquida. Para o uso nos compostos, as fibras são obtidas geralmente da casca externa (HAMID et al., 1983).

Muitos compósitos, mais precisamente os “fiberboards”, são produzidos por fibra e podem ser feitos também de vários materiais lignocelulósicos dando forma aos materiais naturais num processo de refinamento.

Verificou-se que vem sendo pouco explorada a fibra interna, para este fim, como partículas longas e orientadas e distribuídas aleatoriamente, por aparentar não apresentar características de resistência devido à sua baixa quantidade.

Também há uma quantidade de material fibrovascular dispersado em todo o interior da cana-de-açúcar que poderia ser aproveitado para obtenção de um material com características próximas do seu estado primário, criando, no bagaço/resina, um trinômio processo/tempo/custo.

(ATCHINSON, LENGEL, 1985) realizaram um estudo sobre a história e o crescimento da aplicação de "fiberboard” e do "particleboard” do bagaço de cana-deaçúcar, onde eles descrevem as várias aplicações bem sucedidas e o que não deu certo na utilização do bagaço na produção de compósitos de painel. Provavelmente, os aspectos que não resultaram em êxito deveram-se ao processo de produção aditado pelos autores.

Os painéis densos de fibras de bagaço de cana apresentam propriedades físicomecânicas de (GOMEZ et al., 1996):

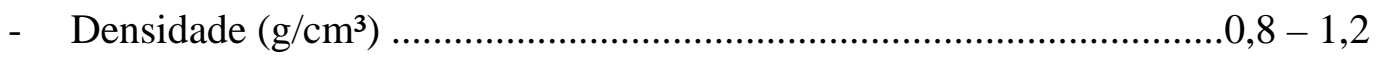

- Resistência na flexão estática (MPa)...................................................30 - 55

- Tração longitudinal às fibras (MPa)...................................................21 - 40

- $\quad$ Absorção em água por 24 horas (\%).......................................................10 - 30

- Inchamento por 24 horas (\%)............................................................ 15 - 20 
- Módulo de elasticidade (MPa).

$.2800-5600$

- Condutividade térmica $\left(\mathrm{kcal} / \mathrm{mh}^{\circ} \mathrm{C}\right)$

$.0,13$

A área canavieira apresenta um fato iminente: o binômio açúcar/álcool pode se transfigurar no trinômio açúcar/álcool/bagaço. Este último, que, segundo STUPIELLO (1989) in RIPOLI et al. (1990), tem sido enquadrado nas quase duas dezenas de subprodutos da cana-de-açúcar, já não poderá ser assim considerado no futuro próximo, pois estamos diante do crescimento marcante e rápido do seu valor econômico.

Segundo (ROMEIRO, 1991), do ponto de vista tecnológico, já há uma série de alternativas, mas estas dependem da superação de interesses privados e dos custos ecológicos que só serão aplicados por uma sociedade consciente e organizada.

KIRCHHOFF (1991) afirma que “A queima do canavial implicará em danos irreparáveis à em razão dos aspectos ligados à poluição atmosférica, por interferir na camada de ozônio”.

Em diversos países canavieiros, a técnica da colheita mecânica da cana crua já é realidade e, certamente, a um curto prazo, será adotada no Brasil, em decorrência dos aspectos ecológicos, conservacionistas, industriais e, especialmente, energéticos envolvidos no processo de queima prévia dos canaviais, que leva a um desperdício inútil de energia. Só assim, essa técnica poderá, num futuro bem próximo, ampliar os lucros do setor sucroalcooleiro e do país, de acordo com trabalho de (RIPOLI, VILLA NOVA, 1992).

O adequado gerenciamento ambiental é necessário para frear a degradação da natureza e a conseqüente decadência da qualidade de vida, tanto nas cidades como no campo. Também é importante notar que a necessidade de produzir deve ser 
compatível com a necessidade de preservar o meio ambiente (CARNEIRO et al., 1993).

Segundo (MAGALHÃES, BRAUNBECK, 1998), entre os estados brasileiros que cultivam e processam a cana-de-açúcar, “São Paulo é responsável por 62\% da canade-açúcar, 64\% do álcool e 56\% do açúcar produzidos no Brasil”. Essa produção encontra-se distribuída nos 2.300.000 ha de cana-de-açúcar cultivada. Da produção total brasileira, atualmente apenas 30\% da colheita da cana-de-açúcar é mecanizada, sendo o restante colhido manualmente.

O bagaço da cana-de-açúcar vem se tornando cada vez mais caro como combustível para as caldeiras de usinas e destilarias de álcool. Este fato ocorre em face da expansão de seu uso como matéria-prima de pesquisa para fabricação de papel, papelão, corrugado e outros (MATTOS, MATTOS, 2004).

(MATTOS, MATTOS, 2004) comentam também que há alguns anos são conhecidas as conveniências e as vantagens de levar à usina a “cana limpa” em lugar da “cana queimada”. Se no princípio a abordagem era apenas de ordem técnica, atualmente ela é muito mais que isso: é também de ordem sanitária e ecológica, na medida em que evitar a queima dos canaviais garante um ar mais respirável e maior proteção ambiental em todas as regiões produtoras.

(MALLIK et al., 1984) observaram o entupimento dos poros da camada superficial do solo pelas cinzas oriundas das queimadas, promovendo a formação de crosta superficial que reduz a infiltração da água e piora a sua aeração.

O valor econômico extraordinário que está em jogo é o que se perde, em cada safra, com as queimadas da palha que poderia e deveria ser aproveitada como fonte energética útil e barata nas caldeiras de todas as unidades produtoras (RIPOLI et al., 1990) in (MATTOS, MATTOS, 2004). Pode-se, ainda, utilizar o bagaço para outros 
fins mais nobres, aproveitando e explorando mais suas propriedades físicas e mecânicas, tornando-o economicamente muito viável e ecologicamente correto.

Esta matéria-prima depende do processo de colheita da cana, sendo preferível a colheita da cana-de-açúcar inteira, sem queima, para que não haja perdas de propriedades químicas, físicas e mecânicas. A Figura 2.1 apresenta um aspecto geral de um canavial queimado e aguardando a colheita manual.

Vale ressaltar também que, com a queima, o tecido fibroso apresentará uma redução na sua resistência mecânica, ocasionando uma menor aplicabilidade do resíduo.

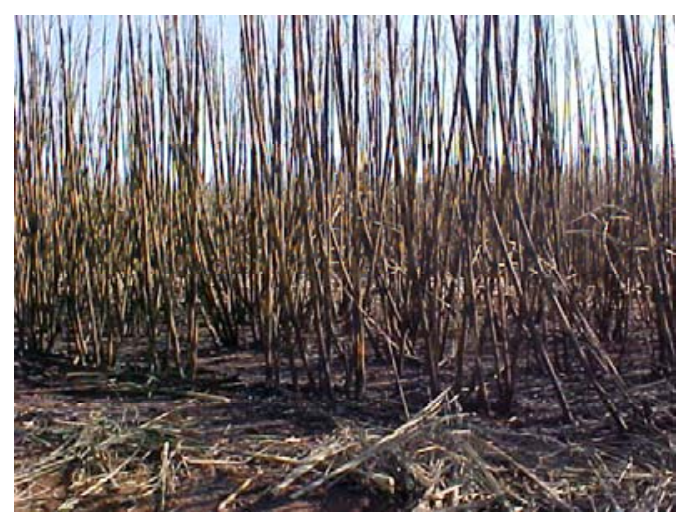

Figura 2.1. Queima da cana-de-açúcar para colheita

Baseando-se nestas informações, verifica-se interesse e vasto campo de aplicação para o resíduo de cana-de-açúcar na forma de bagaço, sem queima, sem separação de matéria (fibra e medula), com aproveitamento até do nó da cana, com tamanho de fibra superior a $5 \mathrm{~cm}$ de comprimento, no intuito de dar um maior valor agregado, explorando suas características de resistência e impacto econômico em busca de um novo material, de fácil acesso de produtividade, baixo custo de processo e propriedades superiores aos normalizados. Valoriza-se, assim, esta matéria-prima para ampliar as possibilidades de um material nobre. 
Vale ressaltar que o bagaço de cana-de-açúcar, depois de preparado como partículas longas e orientadas, adquire propriedades satisfatórias e se encontra dentro da norma utilizada pelas indústrias no mercado mundial de produção de OSB.

\subsection{OSB “Oriented Strand Board”}

Supõe-se que lâminas de compensado foram produzidas há mais de 3360 anos. Uma descoberta arqueológica de 1361 a.C., o trono encontrado na tumba de Tutancâmon, feito em cedro e revestido com finas lâminas de marfim, apresentava características de painel compensado. Seu material abrasivo era a pedra-pome e seus adesivos à base de albumina.

Assírios, babilônios e romanos também promoveram avanço, com influência dos egípcios.

Em 1858, Lyman (EUA) desenvolveu a primeira patente em chapas de fibras.

Em 1866, Fleury (EUA) desenvolveu a patente para fabricação de chapas de fibras isolantes pelo processo úmido.

Em 1880, teve início o desenvolvimento da tecnologia de produção de chapas duras e isolantes pelo processo úmido;

em 1913, início da produção de compensado no mundo;

em 1914, instalação da primeira fábrica de chapas isolantes baseada na tecnologia de produção de papelão;

em 1930, instalação da $1^{\text {a }}$ fábrica de chapas duras com a utilização de toretes de madeiras;

em 1931, desenvolvimento do equipamento desfibrador “Asplund” na Suécia, utilizando o método contínuo de desfibramento à alta temperatura e pressão; em 1932, instalação da $1^{\text {a }}$ fábrica de chapas de fibra na Alemanha; 
em 1940, início da produção de compensado no Brasil;

em 1943, desenvolvimento do sistema de formação do colchão por método pneumático (ar), idéia básica para o desenvolvimento do processo seco e semi-seco;

em 1951, início da produção de chapa dura pelo processo semi-seco;

em 1955, produção de chapas de fibras no Brasil;

em 1966, produção de chapas de madeira aglomerada no Brasil;

em 1970, produção de MDF;

em 1975, início da produção de “Waferboard” e OSB no mundo;

em 1997, início da produção de MDF no Brasil;

em 2002, início de produção de OSB no Brasil.

(Fonte: Revista da madeira, $\mathrm{n}^{0} 71$, ano 13, maio/2003)

O OSB é um painel estrutural com várias classificações, considerado como uma segunda geração melhorada dos painéis WAFERBOARD, produzido a partir de partículas “strands” de madeira, sendo que a camada interna pode estar disposta aleatoriamente ou perpendicular às camadas externas. A diferenciação em relação aos aglomerados tradicionais se refere à impossibilidade de utilização de resíduos de serraria na sua fabricação e de outros derivados de fibras naturais. Além disso, possui um baixo custo, as suas propriedades mecânicas têm caracteres estruturais e não concorre diretamente com o MDF que, ao contrário, não possui essa função. O seu concorrente direto é o painel compensado que apresenta indicações para os mesmos tipos de usos, podendo substituir plenamente os compensados estruturais, em algumas circunstâncias, com resultados superiores ao tradicional.

O “Oriented Strand Board” é um tipo de painel de concepção técnica avançada, constituído por lâminas de madeira ou similar (partículas longas, largas e finas) aglutinadas por uma mistura colante, com uma resina sintética, prensadas em 
camadas. Em geral, nas camadas exteriores as partículas estão dispostas longitudinalmente em relação ao comprimento da placa, enquanto nas camadas intermédias estão dispostas perpendicularmente a essa dimensão ou aleatoriamente distribuídas, como mostra a Figura 2.2:
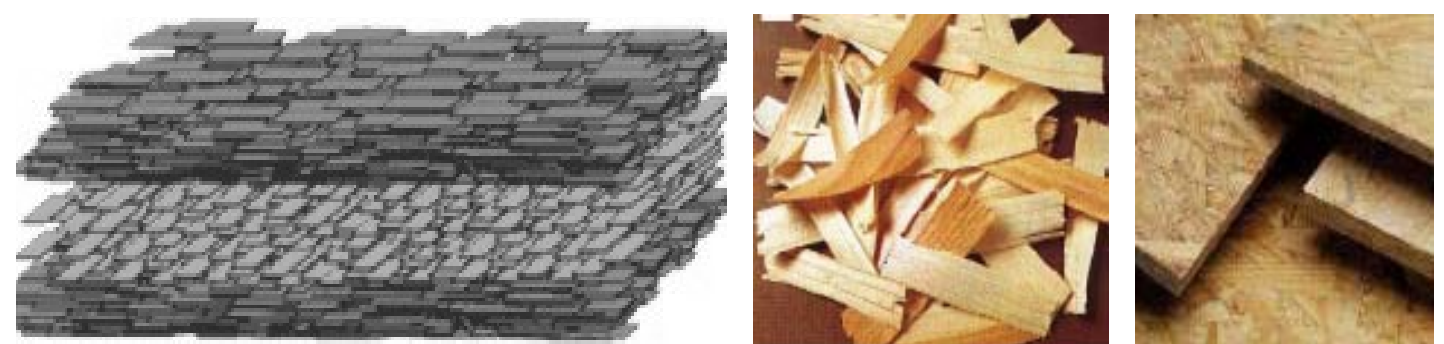

Figura 2.2 Camadas orientadas, partículas longas, painéis OSB do mercado

Em 2000, a primeira fábrica nacional, a Masisa do Brasil, começou a ser instalada em Ponta Grossa (PR). Finalizada em dezembro de 2001, a produção nacional iniciou-se em janeiro de 2002.

Este avanço se deve principalmente a quatro fatores, conforme apresentado na Revista da Madeira, ano 16, $\mathrm{n}^{\circ} 97,2006$ :

- Melhor aproveitamento das toras de madeira (OSB utiliza 96\% contra 56\% do compensado), otimizando o custo e proporcionando um produto ecologicamente mais eficiente.

- Possibilidade da utilização de toras mais finas (6 anos para o OSB contra 14 anos para o compensado) e de menor valor comercial.

- Produtividade maior devido ao processo de fabricação totalmente automatizado e em grande escala: a fábrica existente no Brasil utiliza 24 pessoas em 3 turnos para operar uma linha de produção de 350.000 m³/ano, enquanto uma fábrica de compensado necessita de mais de 200 pessoas para produzir em torno $80.000 \mathrm{~m}^{3} / \mathrm{ano}$. 
- Características do produto, tecnicamente similar ao compensado, mas com custo menor, que permitem uma ampla variedade de usos e aplicações.

As vantagens de se utilizar o OSB, em relação à madeira sólida, se devem aos aspectos de rendimento em relação ao volume das toras, diminuição da anisotropia, utilização de madeiras de reflorestamento de rápido crescimento e madeiras de densidade média que, na confecção do painel, conferem rigidez suficiente para aplicação estrutural (WATAI, 1996).

Segundo CLOUTIER (1998), a geometria das partículas “strand” são as variáveis mais importantes na fabricação de painéis OSB, pois a orientação predomina geometricamente. O comprimento e a largura das partículas são parâmetros que controlam o grau de orientação na formação dos painéis OSB.

Segundo CLOUTIER (1998), as chapas “OSB” também são utilizadas para aplicações estruturais, tais como: paredes, suportes para pisos e forros, componentes de vigas estruturais, embalagens etc, tendo em vista as suas boas características de resistência mecânica e estabilidade dimensional.

GEIMER (1982) afirma que partículas do tipo “strand” proporcionam melhor orientação que partículas do tipo “sliver” ou "flake”, por apresentarem uma melhor orientação e baixo desvio padrão.

Segundo MALONEY (1984), a relação entre o comprimento e a largura das partículas deve ser de, no mínimo, três, para proporcionar boa orientação das partículas no painel, sendo esta relação utilizada por MARRA (1992) para classificar as partículas “strand”.

KELLY (1977) relata que é muito freqüente encontrar, na literatura, indicações de que, na relação entre o comprimento e a espessura (índice de esbeltez), a espessura tem o efeito mais notável, principalmente próximo de 0,5mm. Outro aspecto 
importante encontrado por esse pesquisador foi que, em algumas pesquisas, a relação comprimento/espessura das partículas “flake” foi utilizada na correlação com o MOR. No entanto, não foram encontradas boas correlações quando considerados comprimento e espessura separadamente.

Nesta linha de raciocínio, (CANADIDO et al., 1990) concluíram que o MOR paralelo e perpendicular dos painéis OSB, produzidos com partículas, são afetados pelo índice de esbeltez.

Dentro deste aspecto, GEIMER (1982) notou um acréscimo no valor do MOR e MOE, com a ampliação da largura das partículas. Também foi constatado que, para largura de partículas abaixo de 12,7mm, esta se torna um fator de menor importância no desenvolvimento das propriedades de flexão.

SOBRAL FILHO (1981) ressalva que a largura das partículas anteriormente, também tenha sido um parâmetro de estudo. Entretanto, na atualidade sua influência não é tão significativa como o comprimento e a espessura.

SOBRAL FILHO (1981) também produziu painéis OSB, misturando dois tipos de partículas "strand” (ring flaker e drum flaker), na proporção de 0, 25, 45, 60 e 75\% da primeira em relação à segunda e chegou à conclusão de que, de maneira geral, esta combinação afeta significativamente as propriedades dos painéis produzidos. Os painéis contendo acima de $75 \%$ das partículas menores (pulp chip strands) não alcançaram os valores mínimos de MOR e MOE estabelecidos por norma.

ZHOW (1990) afirma que partículas orientadas causam um aumento de 40 a 50\% no MOR e MOE, respectivamente, no sentido paralelo à orientação em relação aos painéis de partículas distribuídas aleatoriamente.

Atualmente, existem pesquisas com a finalidade de desenvolver tipos de chapas OSB com características mecânicas ainda superiores. (ZHANG et al., 1998) conseguiram 
um aumento no MOR e MOE de painéis OSB, de $47 \%$ a $124 \%$ e de $30 \%$ a $65 \%$, respectivamente, utilizando partículas ultrafinas nas camadas externas $(0,1 \mathrm{~mm}$ de espessura) e, nas camadas internas, numa média de $0,5 \mathrm{~mm}$.

(TOMASELLI, LOPES, TUOTO, 1998) já comentavam, em seu trabalho, que o próximo painel à base de madeira a ser produzido no Brasil seria o OSB “Oriented Strand Board” e ressaltam que o Brasil seria, em curto prazo, um dos maiores mercados para tal produto.

Segundo (SUZUKI, TAKEDA, 2000), o ângulo formado na distribuição das partículas no colchão é altamente dependente da altura de queda das partículas, sendo que alturas menores proporcionam melhor orientação, em conseqüência de o ângulo formado ser menor. Os mesmos autores relatam também que o ângulo formado na distribuição das partículas no colchão é altamente dependente do comprimento das partículas, ou seja, partículas mais longas proporcionam melhor orientação, aumentando assim as propriedades de flexão.

Os aspectos que fizeram com que o OSB se tornasse um painel reconhecido em todo mundo são, segundo ALBUQUERQUE (2000):

- ser um painel estrutural de madeira aprovado por normas da América do Norte;

- ter reconhecimento como um painel estrutural por normas do Japão e Europa;

- estar sendo aceito como painel estrutural na maioria dos países industrializados;

- requerer moderada quantidade de matéria-prima;

- $\quad$ apresentar custo de produção competitivo;

- seus limites mínimos de resistência serem superiores aos de outros painéis estruturais; 
- $\quad$ ter grande potencial na expansão de mercado.

Estes aspectos indicam que os painéis, ou chapas de partículas orientadas, têm um mercado futuro muito promissor, efetivando ainda as múltiplas possibilidades no desenvolvimento deste trabalho.

MENDES (2001) produziu painéis de partículas orientadas (OSB), com Pinus spp, concluindo que a largura das partículas com 15, 20, 25mm não afetam as propriedades mecânicas e estes painéis adquiriram melhores resultados quando feitos a densidade de $0,80 \mathrm{~g} / \mathrm{cm}^{3}$.

(BORTOLETTO JR., GARCIA, 2004), avaliando e comparando a substituição direta de compensado por OSB, concluem não recomendar sua prática porque, embora esses painéis apresentem propriedades físicas similares, como massa específica aparente, suas propriedades mecânicas são diferenciadas, indicando que a substituição deve ser precedida de estudos aprofundados que levem em consideração a magnitude das propriedades requeridas pelos produtos em uso.

(HAN, WU, 2004) confeccionaram um OSB com 50\% casca externa da cana-deaçúcar e 50\% de lascas de pinus, para fins de compósitos estruturais, verificando uma similaridade desta parte externa da cana com a madeira, porém com menos homogeneidade, menor estabilidade térmica e resistência à tração levemente superior à das lascas de madeira para fins estruturais. No entanto em seu trabalho não trazem informações suficientes para avaliação do bagaço de cana-de-açúcar como OSB.

A EN 300 define quatro tipos de OSB de acordo com sua resistência mecânica e suas propriedades físicas:

- OSB/1 - Placas para usos gerais e placas para componentes interiores (incluindo mobiliário), utilizadas em ambiente seco; 
- $\mathrm{OSB} / 2$ - Placas para fins estruturais, utilizadas em ambiente seco;

- OSB/3 - Placas para fins estruturais, utilizadas em ambiente úmido;

- $\mathrm{OSB} / 4$ - Placas para fins estruturais especiais, utilizadas em ambiente úmido. A norma européia (EN 300) também determina os requisitos de valores limites para as propriedades mecânicas de módulo de resistência à flexão e módulo de elasticidade na transversal e longitudinal, adesão interna, adesão interna em água fervente e inchamento em espessura após 24 horas. Logo, há interesse em desenvolver um material que supra as qualidades de OSB requeridas por norma e garantindo propriedades superiores com relação econômica adequável e com valor agregado.

\subsection{A resina}

No OSB, as partículas longas são unidas com os tipos de resina usados habitualmente: as de fenol-formaldeído ("Phenol formaldehyde" - PF), as de melamina-uréia-formaldeído ("melamine fortified Urea Formaldehyde" - MUF) ou a poliuretana à base de di-isocianato (PMDI). Todos estes ligantes são resistentes à umidade e os painéis prensados sob alta ou média temperatura, aumentando suas resistências mecânicas e rigidez (EN 717 - 1 e 2).

Com a segunda guerra mundial, outras resinas foram desenvolvidas, como a resorcinol formaldeído e as primeiras resinas poliuretanas, fazendo-se um retrocesso desde 1937, quando o Dr. Otto Bayer, cientista que por mais de 30 anos chefiou o departamento de pesquisas da empresa BAYER, descobriu o processo de poliadição dos poliisocianatos, princípio básico da fabricação desses produtos (BAYER, 1947). 
Posteriormente, com a evolução da química de macromoléculas, uma grande variedade de resinas poliméricas, com melhores características quanto ao seu aspecto de adesão, foram desenvolvidas, possibilitando grande expansão das indústrias de resinas à base vinílica, de poliéster, poliuretana etc (MANTILLA CARASCO, 1984). IWAKIRI (1998) concluiu que os mecanismos envolvidos no processo de adesão de partículas são os de adesão mecânica, a teoria da difusão de polímeros e de adesão química. Na adesão mecânica, a resina líquida penetra em substratos porosos, como a madeira e derivados, devido à sua fluidez, ocorrendo posterior solidificação, com formação de "ganchos" fortemente impregnados nas partículas. A teoria da difusão de polímeros explica que a adesão ocorre pela difusão das cadeias poliméricas, enquanto, na teoria da adesão química, ocorre por ligações primárias (iônicas e covalentes) ou por forças secundárias intermoleculares.

VICK (1999), também comenta que estas forças intermoleculares secundárias só podem ser desenvolvidas quando as moléculas estão muito próximas entre si. Por isto, aplica-se em colagem a frio, enquanto, em colagem a quente, deve ser aplicada uma certa pressão sobre as superfícies das juntas a serem coladas. Na adesão ocorre uma força de atração entre as superfícies sólidas e uma segunda fase é formada. Esta segunda fase pode consistir de partículas individuais, como pequenos pingos, pó etc. de película líquida (HOUWINK, SALOMON, 1965).

Segundo JESUS (2000), no início da década de 1980 importante contribuição nacional foi dada no estudo de resina à base poliuretana, pelo Departamento de Química e Física Molecular, do atual Instituto de Química da USP de São Carlos. Os pesquisadores do Grupo de Química Analítica e Tecnologia de Polímeros desenvolveram uma resina poliuretana que possui várias vantagens, como: manipulação em temperatura ambiente, grande resistência à ação da água e de raios 
ultravioleta, grande resistência mecânica e ser oriunda de uns recursos naturais renovável, cuja matéria-prima (mamona) de fácil adaptação climática é encontrada em todo território nacional.

A viscosidade é uma grandeza que caracteriza a existência de atrito entre as moléculas de um fluido, no escoamento da resina. A indústria Franklin Adhesives (2005) relata que o aumento da viscosidade diminui a capacidade de penetração, obtendo menor poder de penetração do adesivo e resultando em linhas de cola localizadas com inferior qualidade de colagem. Quanto mais baixa a viscosidade, maior a aplicabilidade de penetração e absorção do adesivo no resíduo compósito, resultando uma melhor relação do composto cola/resíduo.

Na fabricação do compósito é importante considerar a influência do pH, tanto da resina quanto do resíduo fibroso derivado ou não de madeira. O pH da resina a ser utilizada não deve ultrapassar os limites de 1,5 a 11 , pois podem resultar na degradação das fibras vegetais e prejudicar na qualidade do compósito. O pH baixo pode levar à formação excessiva de espuma na mistura, prejudicando sua aplicabilidade.

Existe uma tendência mundial para o uso de materiais biodegradáveis, não-poluentes e naturais. De acordo com ARAÚJO (1992), esta tendência avançou as pesquisas na área de resina poliuretana, com a descoberta da poliuretana derivada de óleo de mamona, ampliando, assim, novas perspectivas para a sua aplicação.

Conhecida internacionalmente como "Castor Oil” e, no Brasil, por Caturra, a mamona (Ricinus communis) é uma planta da família das euforbiáceas, de onde é extraído o óleo ricinoléico, como subproduto da mamona, também denominado popularmente óleo de mamona. A planta que origina este óleo é encontrada com 
abundância em todo território nacional e, principalmente, nas regiões tropicais e subtropicais do Brasil.

A partir do óleo de mamona é possível sintetizar polióis e pré-polímeros com diferentes características que, quando misturados, dão origem a uma poliuretana. Esta mistura poliol pré-polímero à base de mamona, a frio, ocasiona uma reação de polimerização da mistura. Esta reação dá origem à formação da resina poliuretana, podendo-se variar a relação de quantidade de poliol, obtendo-se, com isso, uma maior ou menor flexibilidade e empregando o catalisador adequado com objetivo de aumentar a velocidade de reação do bi-componente.

ARAÚJO (1992) também realizou uma série de ensaios para determinar as características das várias composições de resinas poliuretanas à base de óleo de mamona. Com relação à estabilidade térmica das poliuretanas, concluiu-se, em termogramas de ensaios, que, próximo de $220^{\circ} \mathrm{C}$, ocorre apenas uma pequena perda de massa, o que evidencia a estabilidade térmica das resinas desde a temperatura ambiente até esta temperatura.

CLARO NETO (1997) determinou as propriedades físico-químicas do polímero de resina poliuretana, bi-componente, derivado de óleo de mamona, desenvolvido para ser utilizado como material de implante ósseo. Em sua pesquisa verificou o comportamento térmico do polímero entre os dois componentes totalmente curados, como mostra, na figura 2.3, a curva de decomposição térmica do polímero. 


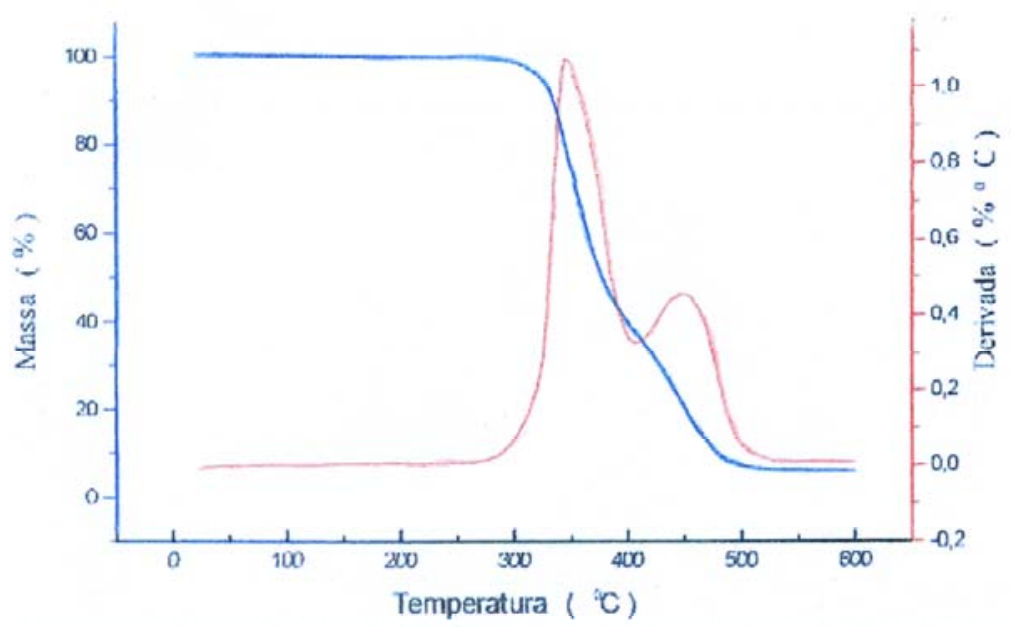

Figura 2.3. Curva de decomposição do polímero em atmosfera de $\mathrm{N}_{2}$ (Fonte: CLARO NETO, 1993)

A curva de decomposição do polímero possui duas etapas, a primeira de 300 a $400^{\circ} \mathrm{C}$, com $65 \%$ de perda de massa, e a segunda de 400 a $500^{\circ} \mathrm{C}$, com $30 \%$ de perda de massa. A primeira decomposição está relacionada ao rompimento das ligações uretanas, visto que está presente em maior quantidade no polímero. A segunda decomposição, que termina em $500^{\circ} \mathrm{C}$, está relacionado à decomposição da ligação éster presente no poliol.

CLARO NETO (1997) definiu também a curva de tração/deformação obtida nos ensaios do polímero poliuretano, apresentando um comportamento de acordo com a Figura 2.4: 


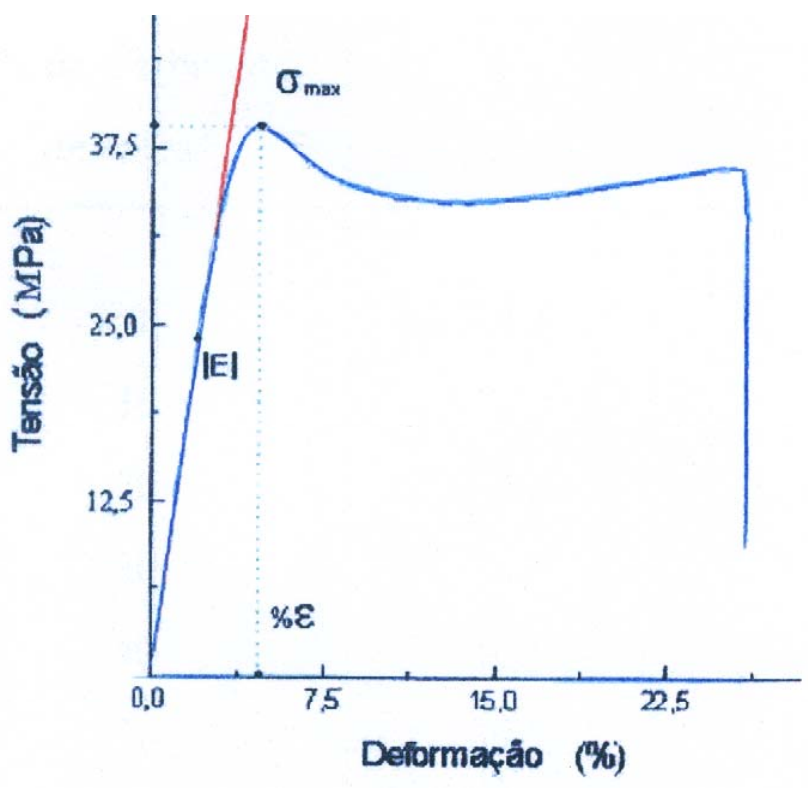

Figura 2.4. Curva do ensaio de tração para amostra do polímero à base de poliuretano puro (Fonte:CLARO NETO, 1997)

Observa-se a resina poliuretana pura à base de mamona sob tração com uma curva típica de polímeros que sofrem escoamento após a região linear de elasticidade, com deformação plástica até a ruptura.

Analisando o gráfico de resistência à tração, verificou-se um comportamento elástico da resina polimérica até 32,5 MPa, logo em seguida tendo início o escoamento para regime plástico com deformação lenta e valor de resistência, nessa deformação, levemente superior ao início de escoamento da plasticidade e atingindo valores de deformação próximos dos 26\%. Esta resina tem grande importância na produção de compósitos poliméricos devido ao seu vasto limite de deformação e resistência.

A resina poliuretana à base de mamona estudada por JESUS (2000) é do tipo bicomponente, composta pelo poliol B1640 e pelo pré-polímero A249, de cura a frio. Após mistura dos componentes, sua viscosidade aumenta e seu tempo de aplicabilidade é próximo de 20 minutos, tempo de utilização reduzido, o que dificultou sua aplicação em estruturas de MLC. 


\subsection{Protocolo de Kyoto}

Segundo OTTMAN, 1994, o ambientalismo “deve ser a questão comercial da década, pois $40 \%$ de todos os novos produtos domésticos apresentam uma alegação ambiental em seu rótulo”. Para consumidores preocupados com sua qualidade de vida, menos agora vale mais, e as decisões de compra são cada vez mais influenciadas pelo impacto que os produtos têm no meio ambiente. A partir deste momento, as empresas que não corresponderem aos anseios (questões ambientais) dos consumidores, por meio de produtos mais seguros e ecologicamente corretos e saudáveis, estarão arriscadas a perder a sintonia com os mesmos, podendo pagar um alto preço pelo não-cumprimento do mesmo. Ao contrário dos anteriores, aqueles comerciantes que prestarem atenção ao chamado do consumidor verão suas oportunidades se multiplicarem.

As empresas também sofrem uma forte pressão por parte da sociedade, já que dependem da aceitação e aprovação desta última para a comercialização de seus produtos (CINTRA, ANDRADE, 2003). Com o intuito de manter sua imagem polida, as organizações passaram a priorizar investimentos em áreas antes não consideradas importantes. Dessa forma, elas conseguiram maximizar seus ganhos e agradar a seus consumidores, mantendo seu setor produtivo sustentável e seus investimentos com retorno garantido mesmo que a médio ou longo prazo, assegurando a permanência e sustentação da empresa ao longo do tempo.

(MATTOS, MATTOS, 2004), em seus estudos, para reduzir a quantidade de queimadas, mostraram a viabilidade econômica do uso da palha da cana-de-açúcar destinada para a geração de energia e sugeriu que o uso do bagaço de cana-de-açúcar seja em produtos de mais alto valor agregado, como tantos exemplos de derivados de bagaço. 
Muitas são as soluções já existentes e outras ainda surgirão para diminuir as emissões de gases de efeito estufa para a atmosfera, evitando um aumento ainda maior das temperaturas por todo o globo. Nessa busca por soluções, muitas são as oportunidades criadas para evitar esse “caos” mundial. Várias empresas estão investindo em novas tecnologias e outras na manutenção de seus equipamentos, de forma a diminuir os gastos e, conseqüentemente, cumprir seu papel de empresa sustentável e ecologicamente correta, promovendo a manutenção do planeta para a vida presente e a de nossos descendentes. 


\section{MATERIAIS E MÉTODOS}

Neste capitulo será abordado os materiais e métodos utilizados.

\subsection{Materiais}

O material utilizado nesta tese é o resíduo da cana-de-açúcar, Saccharum officinarum, gramínea oriunda da Ásia e muito cultivada em regiões tropical e subtropical. Hoje a maior parte das canas cultivadas é um híbrido da planta original com outras espécies da mesma família. O resíduo denominado de "bagaço” é oriundo de moendas localizadas nas proximidades da cidade de São Carlos-SP.

Este material é colhido, após ser passado em moenda, na forma de tiras, composto de vários colmos e levado ao laboratório para tratamento em água. No início do tratamento, a água tem que apresentar $\mathrm{pH}$ 7, para a imersão do bagaço, com o propósito de submetê-lo à retirada de sobras da sacarose que ficou no momento da retirada do líquido.

O bagaço é submerso com intervalos intercalados de tempo de tratamento em torno de 4 horas. Após cada intervalo, muda-se a água para que não ocorra a fermentação, evitando o aumento de acidez. Com isto, chega-se a um melhor controle do $\mathrm{pH}$, pois a tendência do ciclo é provocar a fermentação do resíduo no final do processo de cada intervalo. Completa-se o tratamento após 36 horas. 
Leva-se em contrapartida que o $\mathrm{pH}$ da água, antes do tratamento, apresenta valor sete e, após o tratamento, valor próximo de sete, para que ocorra uma contribuição no controle do produto final sem substâncias livres que podem influenciar negativamente, aumentando a toxidade do material.

A resina utilizada é a poliuretana à base de óleo de mamona, tipo bi-componente: onde o componente A é o poliol preparado da mamona e o componente B sendo o pré-polímero petrolífero da Bayer. Quando misturados estes componentes originam um polímero de resistência elevada e propriedades iguais as resinas tradicionais. O tempo de reação para a formação do polímero é de 25 minutos, tempo suficiente para o processo de fabricação.

A resina foi preparada com o pré-polímero I201 na confecção das chapas e será utilizado o traço na proporção 1:2, sendo uma parte de pré-polímero cujo pH vale 5 e à base de di-isocianato e duas partes de poliol, com o pH próximo de 6. Estes componentes da resina polimérica foram fornecido pela Kehl Indústria Química de São Carlos-SP.

A resina poliuretana à base de óleo de mamona tem cura a frio, que pode ser acelerada com aumento de temperatura até $160^{\circ} \mathrm{C}$, sem perder suas propriedades e redução do tempo de cura para 4 minutos. Optou-se, no início, por $90^{\circ} \mathrm{C}$, no processo de fabricação, com redução de custos operacionais, aumentando a produção com menor trabalhabilidade e ocasionando menor gasto de energia no processo de fabricação dos painéis. Mas este painel compósito foi também acelerado em sua fabricação com o aumento da temperatura para $130^{\circ} \mathrm{C}$, sendo viáveis os dois patamares de temperatura, pois a $130^{\circ} \mathrm{C}$ tem-se uma redução de tempo de processo do painel em torno de 6 minutos e, a $90^{\circ} \mathrm{C}$, um melhor manuseio do processo, porém com aumento do tempo de fabricação para 10 minutos. 
A viscosidade da resina foi definida em equipamento Copo Ford oito. O tempo médio de escoamento da resina variou entre 40 segundos e 50 segundos em uma temperatura ambiente entre 20 e $36^{\circ} \mathrm{C}$, e este tempo de reação da resina é recomendado pela Kehl.

As razões que levaram à utilização da resina à base de mamona, neste trabalho, com relação à temperatura e ao tempo de prensagem são devidas aos estudos (Dias, 2005), que confirmam $90^{\circ} \mathrm{C}$ e tempo de 10 minutos como parâmetros de aplicação na fabricação de painéis.

\subsection{Métodos}

\subsubsection{Termogravimetria (TG) e Análise Térmica Diferencial (DTA)}

Este método tem como finalidade verificar comportamento do resíduo sobre efeito de temperatura até a eventual transformação em cinza, justificando sua temperatura ideal para utilização em compósitos.

Realizada com amostra de bagaço de cana-de-açúcar em forma de resíduo, a curva termogravimétrica foi obtida submetendo o bagaço à análise de termogravimetria (TG) que permite verificar a variação de massa em função do tempo ou da temperatura, acoplada com a análise térmica diferencial (DTA) que mede a diferença de temperatura da amostra analisada com a amostra de referência, determinando as transformações que ocorrem no material analisado. Para esta análise foi utilizada uma termobalança TG-DTA simultânea, marca NETZSCH, modelo STA 409 Cell (Figura 3.1), com uma razão de aquecimento de $10^{\circ} \mathrm{C} / \mathrm{min}$. até a temperatura de $375^{\circ} \mathrm{C}$, pois esta razão de aquecimento promove um padrão de curva com melhor resolução, em atmosfera de nitrogênio. 


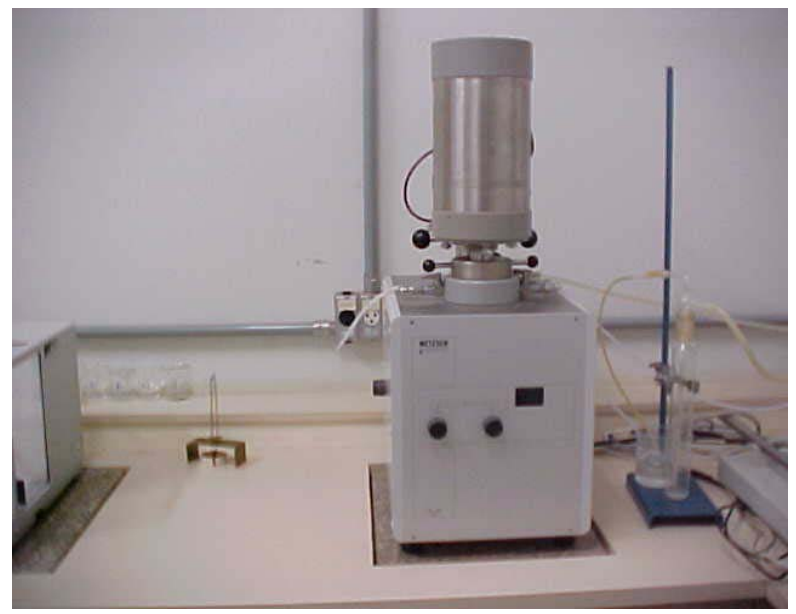

Figura 3.1. Equipamento NETZSCH, modelo STA 409 Cell de análise termogravimétrica (UNESP/IQ/Araraquara)

\subsubsection{Tratamento}

O bagaço foi submerso em água à temperatura ambiente para retirada de sacarose e impurezas. Durante este processo foi verificado o $\mathrm{pH}$ da água de 4 em 4 horas, havendo uma tendência de pH 5 até 30 horas de tratamento. Após 30 horas em tratamento, o resíduo é retirado e apresenta característica robusta devendo ser submetido inicialmente a uma secagem natural, como mostra a figura 3.2.
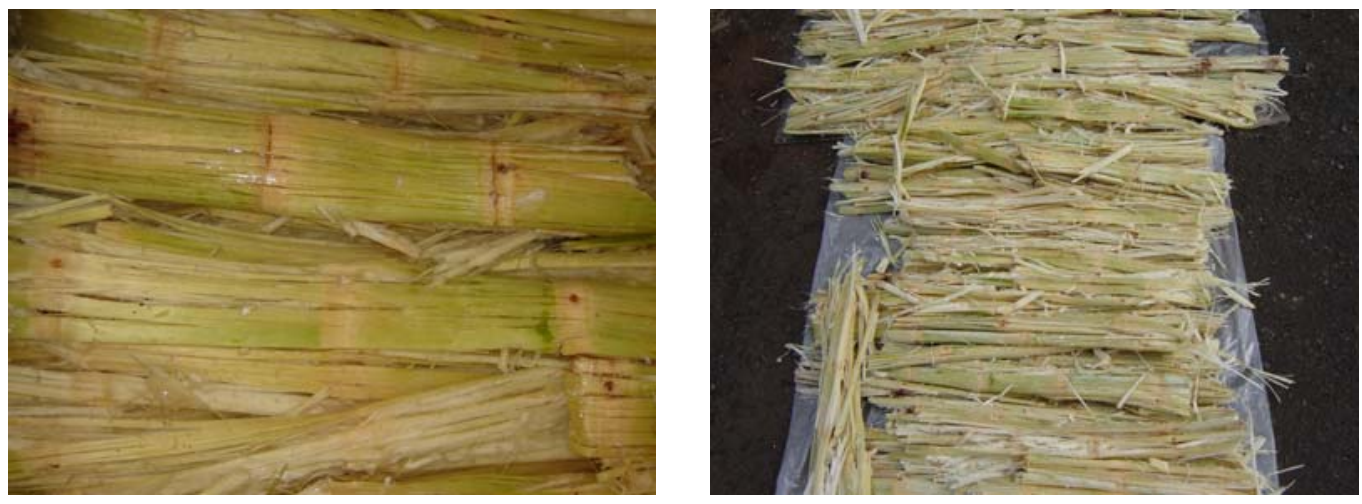

Figura 3.2. Material tratado em água por 30 horas e exposto ao para secagem natural

\subsubsection{Secagem}

O processo de secagem artificial foi feito logo após secagem ao sol, em estufa, por

16 horas, a uma temperatura de $60^{\circ} \mathrm{C}$ como mostra a Figura 3.3. 


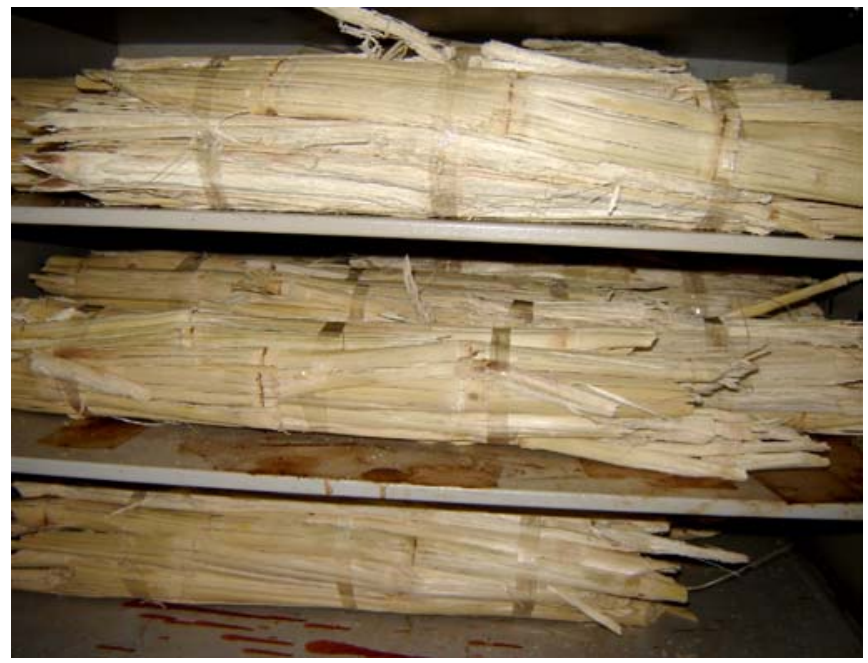

Figura 3.3. Bagaço após tratamento submetido à secagem em estufa

De acordo com (MACHADO, 2000), esta temperatura foi aplicada por não ocasionar modificações na estrutura lignocelulósica do material em análise, pois, acima de $60^{\circ} \mathrm{C}$ há uma perda de água que poderia eventualmente propiciar alguma degradação no material lignocelulósico.

“In natura” o bagaço é bastante úmido, mas, após tratamento e secagem, apresenta uma perda de massa em torno de $45 \%$ a $55 \%$ do seu peso.

Logo após tratamento e secagem, tritura-se $20 \mathrm{~g}$ de bagaço seco em minitriturador para eventual análise de teor de sólidos e teor de umidade, conforme mostra a figura 3.4.

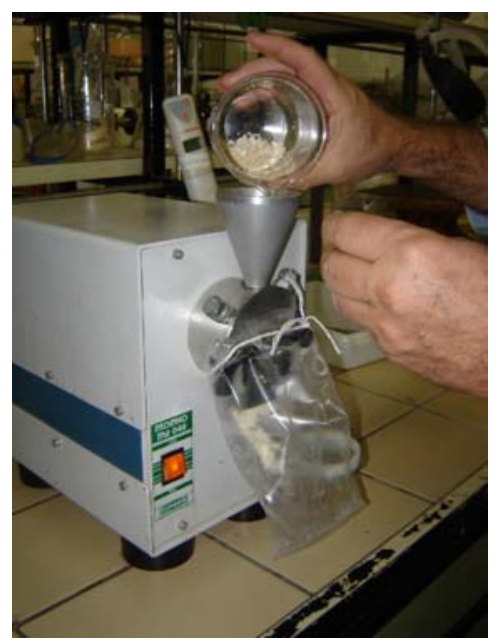

Figura 3.4. Minitriturador para pequenas análises 
Para cada amostra de cinco gramas, num total de quatro ensaios, o material é levado ao equipamento para medir o teor de sólidos e de umidade, sendo submetido a uma temperatura de $105^{\circ} \mathrm{C}$ por 180 minutos. Este procedimento aditado torna-se importante na determinação da extração do teor de sacarose no bagaço.

Logo após, obtêm-se valores entre 3 a 4\% de teor de umidade e 97 a 96\% de teor de sólidos.

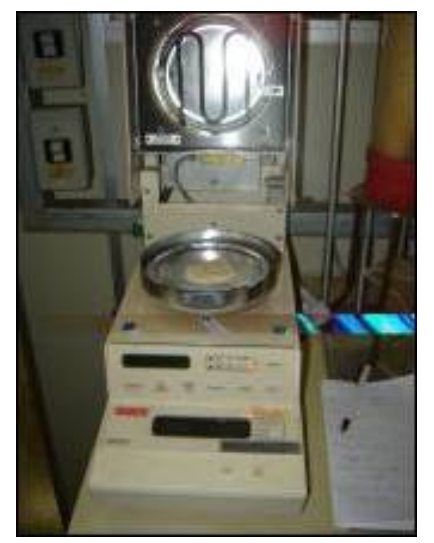

Figura 3.5. Balança eletrônica utilizada nos ensaios de teor de umidade e teor de sólidos

\subsubsection{Extração com água}

A razão de utilização deste procedimento experimental está na analise química do processo, que define a redução da quantidade de sacarose no bagaço de cana, que será considerado quase totalmente extinto a partir do ponto de massa constante, que ocasionará o final de teor de sacarose no resíduo.

Após a primeira e a segunda extração de sacarose, as mesmas amostras foram submetidas a outras extrações tendo, como solvente, a água destilada, com aproximadamente 6 horas de tempo para cada extração, a uma temperatura de ebulição. Repetiu-se o processo por um tempo de 36 horas, num total de 6 extrações, para completar o ciclo de massa constante, como mostra figura 3.6. 


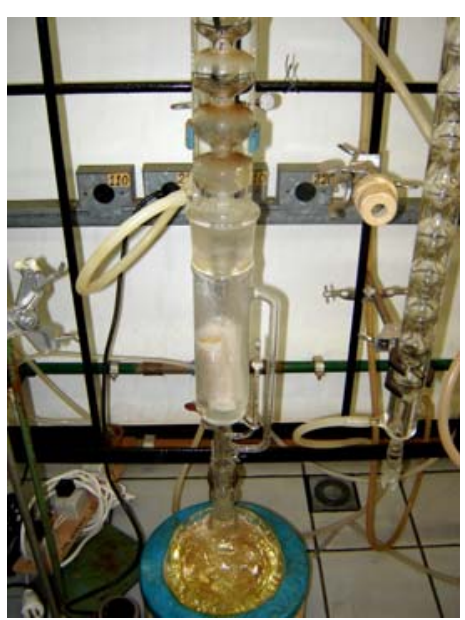

Figura 3.6. Extração de sacarose a temperatura de ebulição

Após as seis extrações, as fibras foram secas inicialmente ao ar, por 6 horas e, posteriormente, em estufa por 16 horas, com temperatura máxima de $60^{\circ} \mathrm{C}$. O teor de extrativos foi determinado pela seguinte expressão:

$$
\mathrm{S}=\frac{\mathrm{m}_{\mathrm{i}}-\mathrm{m}_{\mathrm{f}}}{\mathrm{m}_{\mathrm{i}}} .100
$$

Onde:

$\mathrm{S}=$ teor de extrativos $(\%)$

$\mathrm{m}_{\mathrm{i}}=$ massa de amostra seca antes da extração $(\mathrm{g})$

$\mathrm{m}_{\mathrm{f}}=$ massa de amostra seca após a extração $(\mathrm{g})$

Já seco e com análise de teores de extrativo, o bagaço foi preparado para obtenção do particulado (Figura 3.7), sendo cortado em serra circular em pedaços de comprimentos similares com aproximadamente $15 \mathrm{~cm}$ e adequados aleatoriamente sem separação ou classificação de camadas, e sem preferência de posição. Morfologicamente o material é constituído de casca, nó e medula fibrosa: 

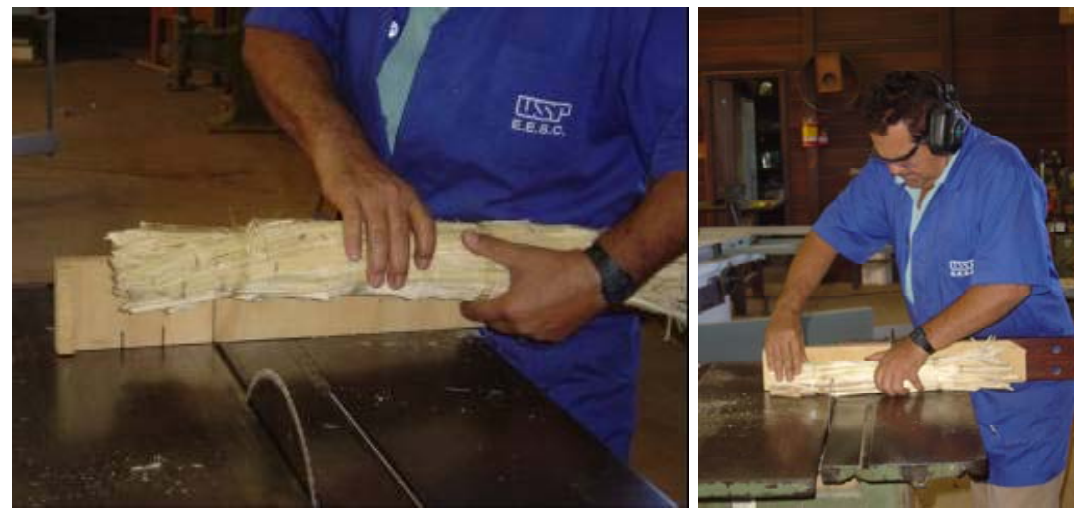

Figura 3.7. Corte do bagaço de cana-de-açúcar definindo tamanho de partículas longas

\subsubsection{Mistura}

O processo de mistura influencia no grau de compactação deste resíduo, para está nos padrões utilizados para fabricação de Oriented Strand Board (OSB) em escala industrial. O bagaço de cana oferece uma variada opção de uso, pois tem fibras de baixa densidade, matéria disponível e de baixo custo. Na mistura da confecção deste trabalho, utilizou-se a resina poliuretana à base de óleo de mamona, na proporção 1:2, proporção esta determinada pelo fabricante, baseando-se em informações químicas de análises em infravermelho entre os dois componentes desta resina polimérica e o polímero definitivo nesta proporção, sendo que uma parte é de prépolímero com teor de pH 5 e duas partes de poliol com teor de $\mathrm{pH}$ 6. A proporção de resina em relação ao resíduo lignocelulósico de bagaço de cana utilizada foi de 10 e 20\% da massa do resíduo de bagaço de cana, para a proporção de compactação e densidade desejadas optou-se por 1100g de massa de resíduo.

A priori apresentam-se alguns detalhes do misturador, onde fica definido o local para o processo da mistura em reservatório cilíndrico e a tubulação para o transporte da resina do sistema de ar-comprimido até o respectivo cilindro misturador, com dimensões especificadas, como mostra a Figura 3.8. 


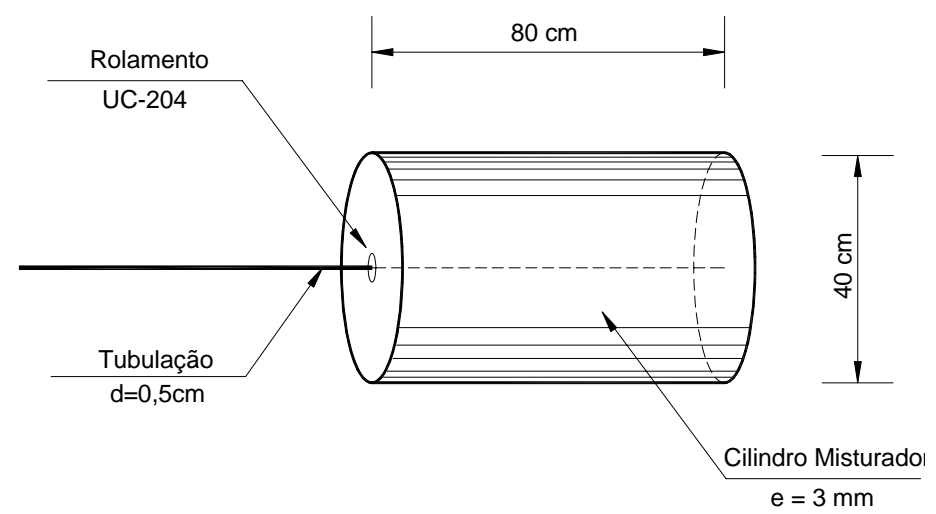

Figura 3.8. Misturador cilíndrico em aço inox e tubulação de transporte da resina, com um tempo de 16 rotações por minuto

O misturador cilíndrico apresenta comprimento especificado inicialmente com 80 cm, base de acesso da tubulação de transporte de resina com $40 \mathrm{~cm}$ de diâmetro e abertura de $2 \mathrm{~cm}$ de diâmetro para acesso de pistola vaporizadora. A outra base em acrílico é similar à primeira, com abertura central e espessura do acrílico entre 5mm a $10 \mathrm{~mm}$ e com diâmetro de $40 \mathrm{~cm}$.

A base em acrílico justifica-se para a visualização do processo no decorrer de sua execução.O sistema de transporte da resina por ar comprimido foi lançado através de um orifício central na base de aço inoxidável do misturador. A centralização da tubulação é devida ao fato de esta posição ter rotação mínima, ocasionando pouco atrito no sistema base e tubulação.

A haste de engate age como vedação do sistema cilindro e base, pressionando o anel, dando-lhe resistência com funcionalidade no manuseio e limpeza do equipamento, conforme ilustrado na figura 3.9, tornando eficaz o processo. 


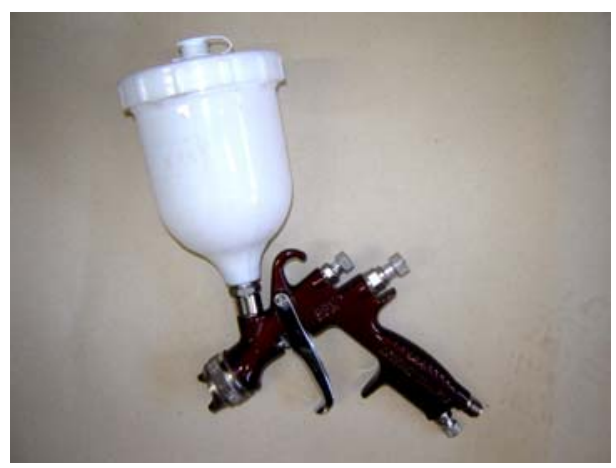

Figura 3.9. Pistola de pintura em ar comprimido

A figura 3.10 mostra vista frontal da bancada, o misturador, a localização dos mancais em um trilho móvel sobre a mesa, que determina, de acordo com o posicionamento e dimensão do cilindro, definindo um ponto para fixação dos mancais. Todas as medidas cotadas estão em centímetro.

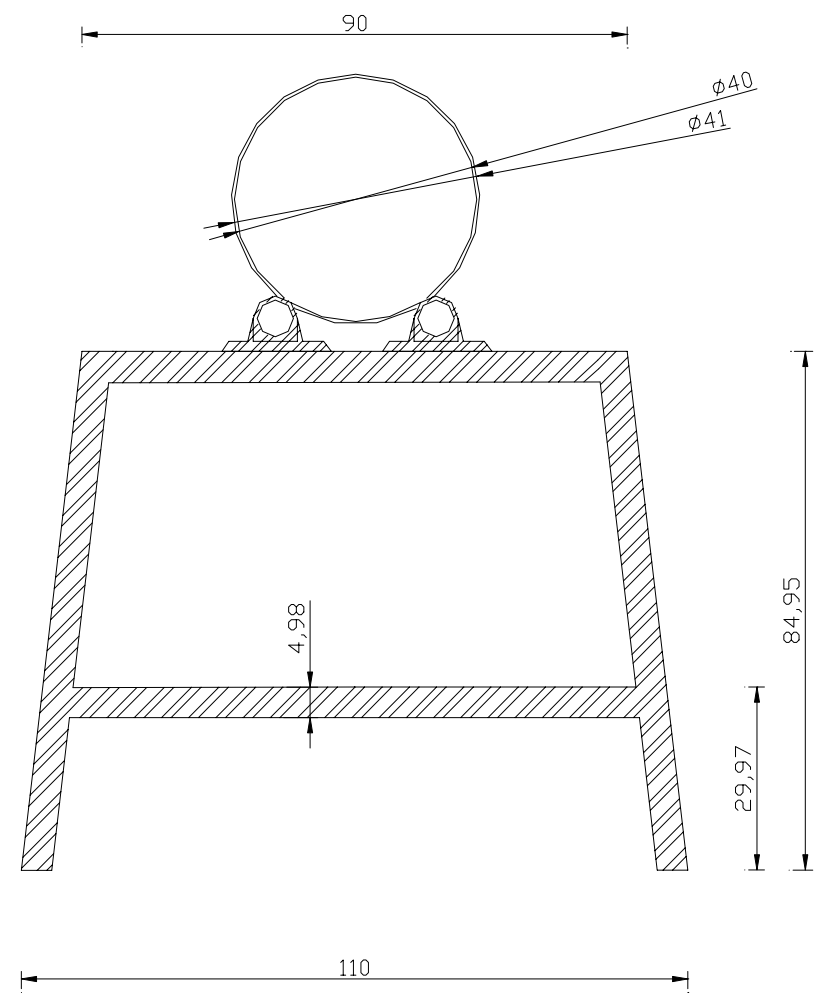

Figura 3.10. Vista frontal da bancada e misturador de lascas e partículas O cilindro misturador, figura 3.11, é apoiado sobre duas barras de rolagem, facilitando a rotação, dando movimentos constantes de ciclos, evitando gastos desnecessários de energia e possibilitando uma eficácia ao sistema. 


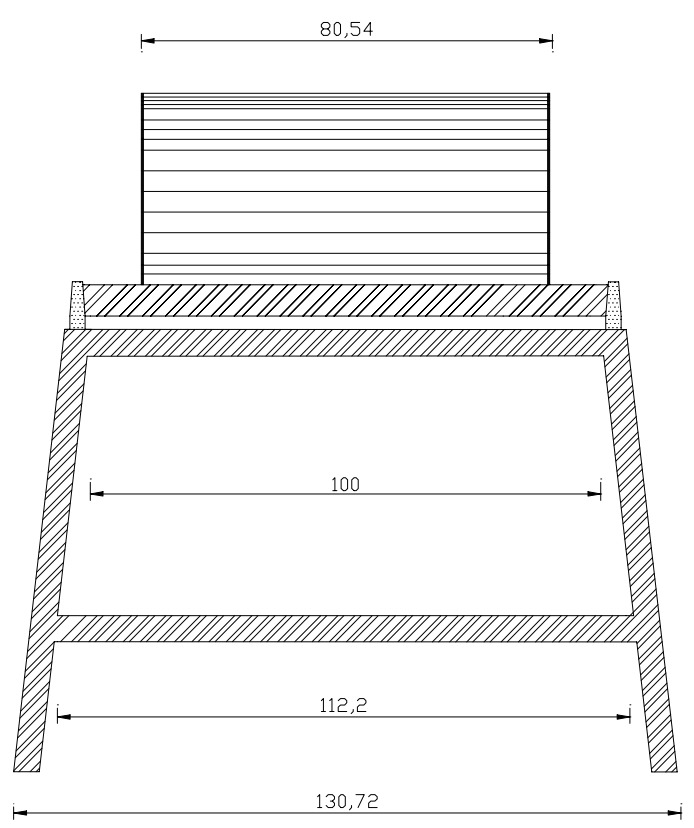

Figura 3.11. Vista lateral da bancada e misturador de lascas e partículas

A figura 3.12 mostra o perfil do sistema desde o cilindro da mistura, tocando pelas barras de sustentação e rolagem, engrenada em uma polia de 250mm A1 com a 90mm A1 que, por sua vez, está sob eixo de um motor monofásico de potência 1cv, diferença de potencial (ddp) 220volts e capacidade de rotação de 1600rpm. Este equipamento possui um frequencimetro, onde a mistura foi submetida a uma rotação de 16 rpm e tempo de mistura de 15 minutos.

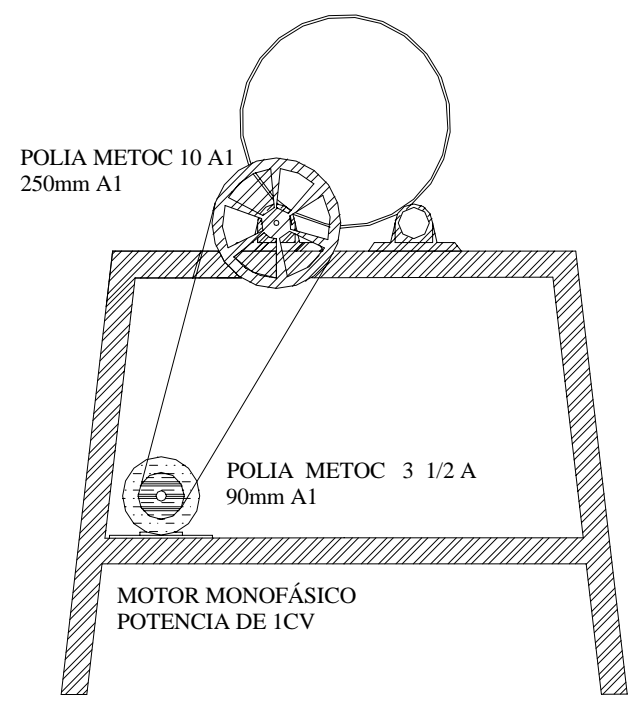

Figura 3.12. Desempenho do sistema cilíndrico, polias e motor no misturador 


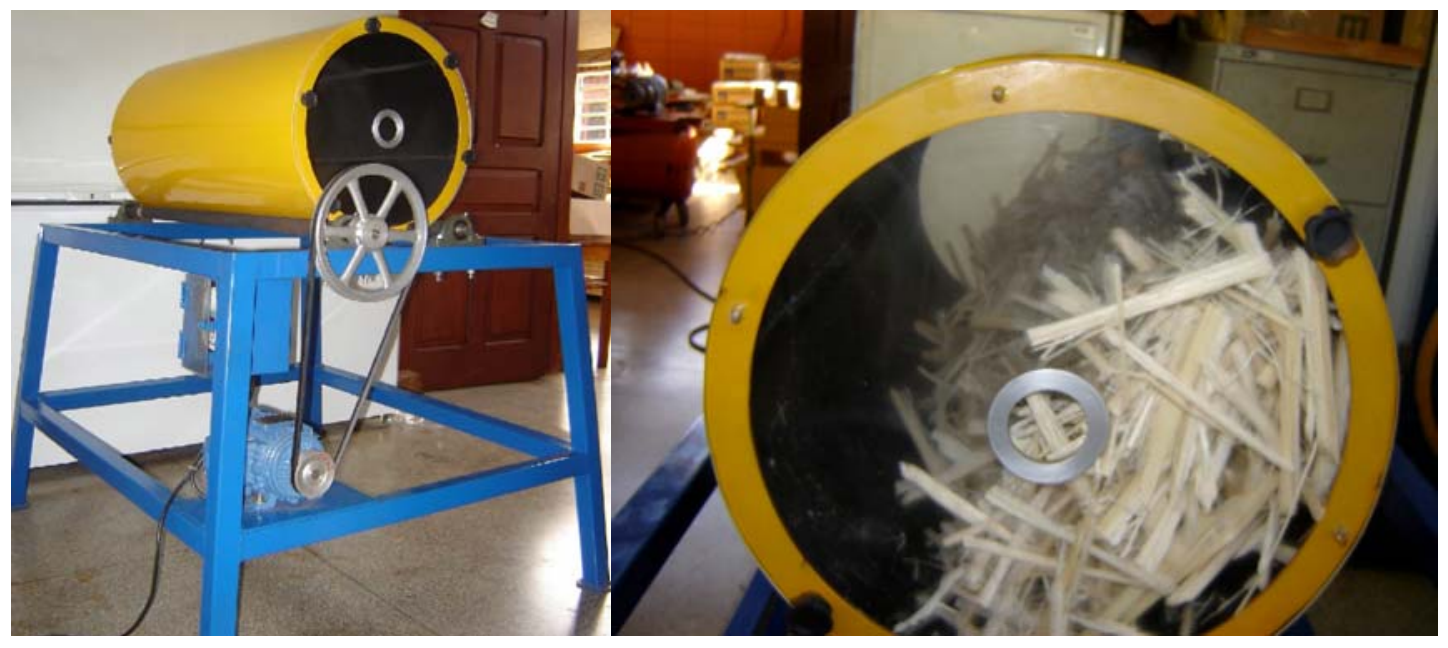

Figura 3.13. Misturador de partículas/resina desenvolvido por Parga no LaMEM Após mistura (Figura 3.13) o material foi levado ao orientador de partículas para otimizar o processo de fabricação (Figura 3.14). Tal orientador foi desenvolvido durante o projeto de tese, conforme descrito logo a seguir.

\subsubsection{Orientador de partículas}

O projeto de orientador metálico para partículas longas, desenvolvido na USP pelo doutorando, Figura 3.14, vem dar melhor aplicabilidade e orientação das partículas longas, ocasionando uma redução de variância nos resultados.

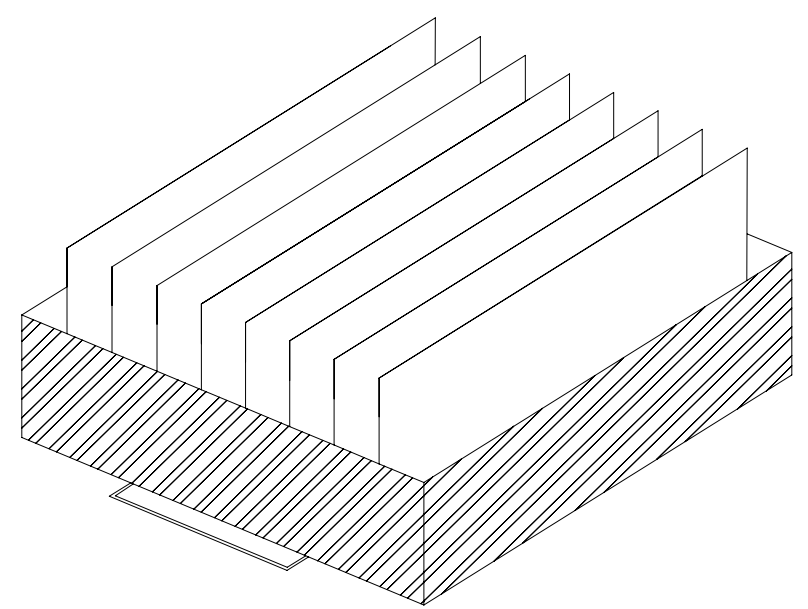

Figura 3.14. Mostra o modelo do projeto de orientador desenvolvido durante esta tese 
Este orientador de partículas tem dimensões de 460mmx460mm de base, 250mm de altura e na base apresenta divisões em secções de nove partes iguais de 40mm, utilizando lâminas metálicas, orientadas e fixas, revestidas com pintura teflon para facilitar o escoamento de resina/resíduo, evitando aderência da resina ao equipamento.

Este projeto de orientador de partícula foi desenvolvido pela necessidade de redução de espaço e tempo de processo na fabricação de placas OSB, em laboratório.

Estrutura de proteção e sustentação do orientador em aço; lâminas para direcionar as partículas, separadas entre si; suporte para manuseio do equipamento, como mostra a figura 3.15 .

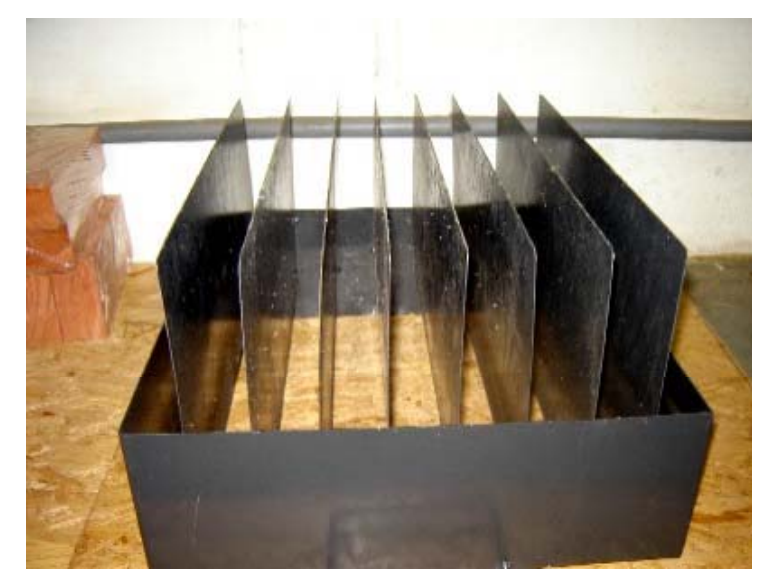

Figura 3.15. Orientador de partículas longas

Depois de orientado, o material foi submetido à prensagem, em prensa a quente, obedecendo a características térmicas deste material e da resina.

\subsubsection{Prensagem}

Após aplicação da resina, as partículas longas foram colocadas em forma de madeira com orientador de partículas, para divisão das camadas em externas e internas. As 
camadas externas têm obrigatoriamente a mesma orientação, já as camadas internas podem estar ou não orientadas (PARGA, LAHR, 2006), como mostra figura 3.16.

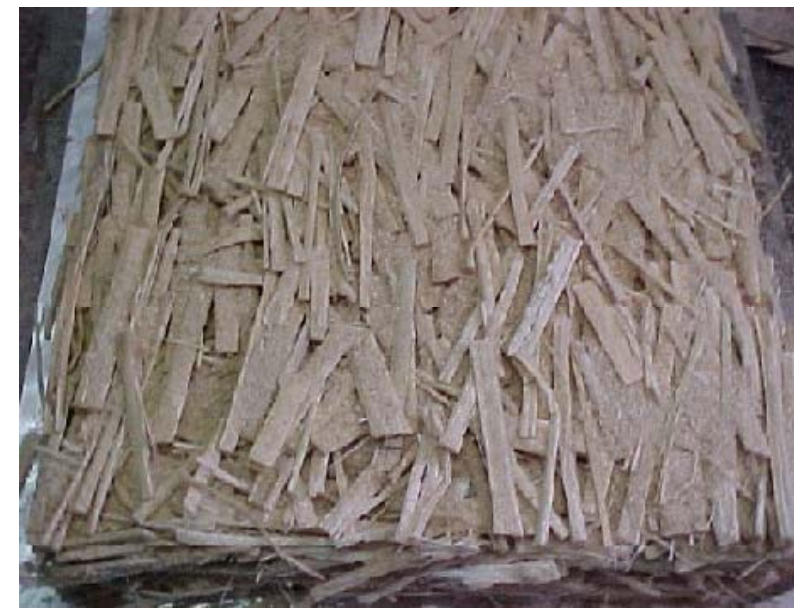

Figura 3.16. Camadas de partículas orientadas de bagaço de cana

Da preparação em misturador até a orientação de partículas, decore um tempo de 12 a 15 minutos, "gel time” da resina à base de óleo de mamona. Logo depois de orientadas, as partículas longas são pré-prensadas, com o objetivo de distribuir uniformemente a compactação do colchão, facilitando seu manuseio. Em seguida são levados à prensa aquecida em temperaturas de $90^{\circ} \mathrm{C}$ e outro em $130^{\circ} \mathrm{C}$ ambas temperaturas sugeridas para este trabalho, prensagem em torno de 1 a $5 \mathrm{MPa}$ de pressão, num intervalo de tempo da prensagem em torno de 10 minutos, na prensa hidráulica Marconi MA-98/50. A temperatura atribuída influencia na aceleração de cura da resina, ou seja, quanto maior for à temperatura mais rápido o processo e estando de acordo com os padrões térmicos de comportamento do bagaço de canade-açúcar na resina. 


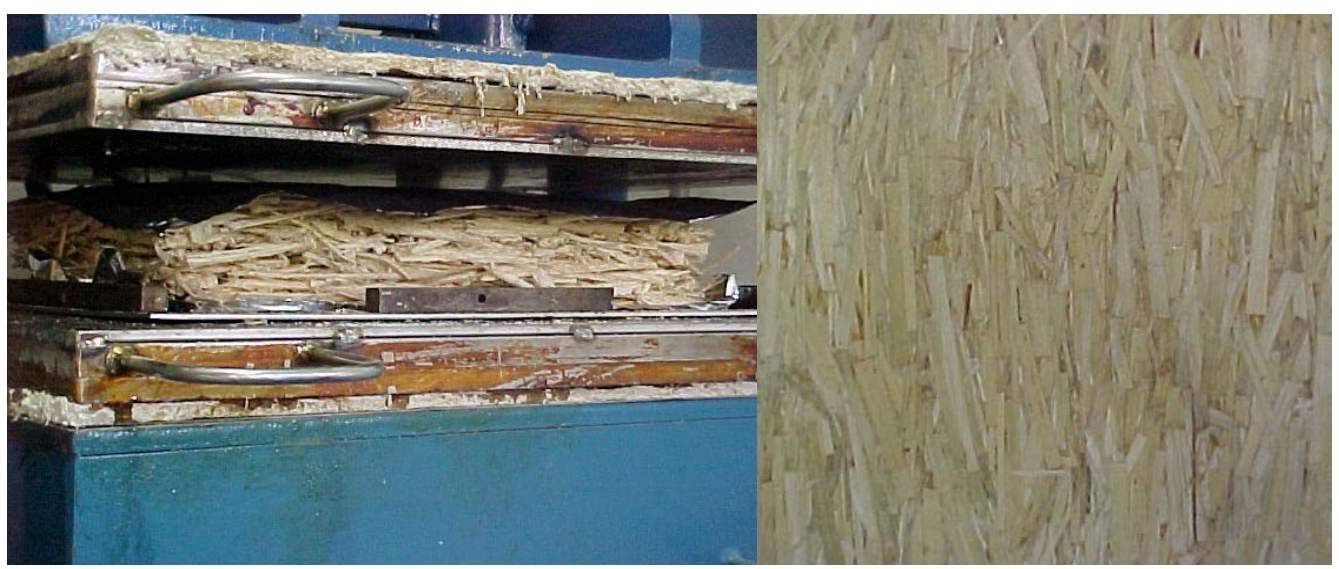

Figura 3.17. Partículas longas em Prensa hidráulica Marconi MA-98/50 e o produto final

Após a prensagem, o produto final é um painel (Figura 3.17). Cada painel será colocado na posição vertical e mantido assim por sete dias. Este tempo é necessário para que os painéis estabilizem a temperatura de prensagem à do ambiente, complementando a cura da resina e correlacionando a umidade das faces e o centro da placa.

\subsubsection{Microscopia Eletrônica de Varredura (MEV)}

A microscopia eletrônica de varredura (MEV) é conforme, uma técnica que utiliza um feixe fino de elétrons que incide na superfície da amostra, interagindo com o material. Os elétrons secundários são coletados por um detector que converte o sinal em imagem. Estas imagens documentam a relação processo e propriedades adquiridas pelo produto final através de fotos microscópicas que certificam o comportamento entre resina e fibras do resíduo.

A análise microscópica foi feita utilizando o equipamento de microscopia eletrônica de varredura TOPCOM modelo SM-300 (Figura 3.18). As amostras foram lixadas (lixa $\mathrm{n}^{\circ} 320,400,600$ ) e submetidas a um banho com ouro na camada externa, para facilitar a conversão de sinal em imagem. Essa análise de MEV teve por objetivos 
observar a topografia superficial das amostras e seus contornos de resíduo/resina; obter a microestrutura das amostras e verificar o potencial de impregnação da resina no resíduo de bagaço de cana-de-açúcar.

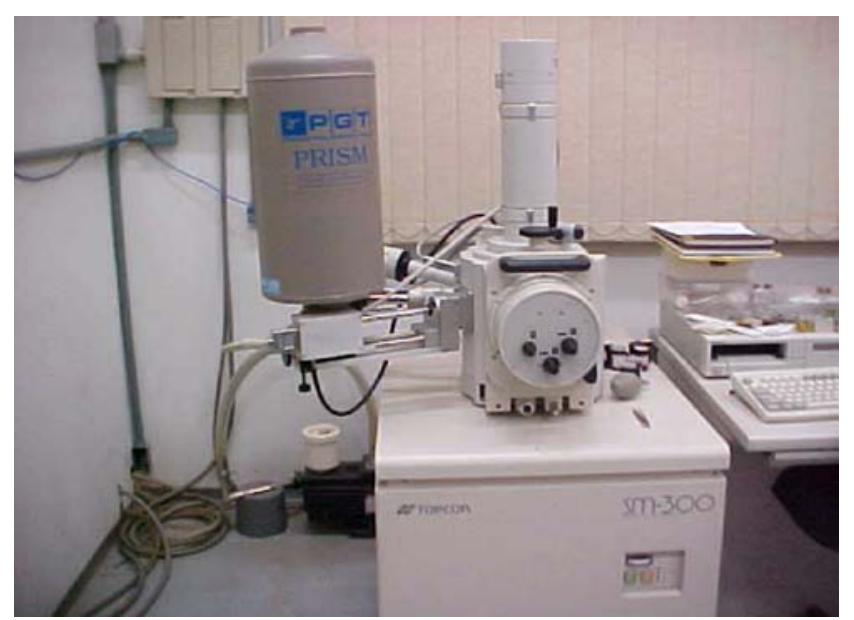

Figura 3.18. Equipamento de microscopia eletrônica de varredura (MEV)

\subsubsection{Espectroscopia de Absorção na Região do Infravermelho}

Para as caracterizações dos espectros de absorção na região do infravermelho foram realizadas as análises em separado do poliol e do pré-polímero, nos compósitos à base de bagaço de cana-de-açúcar, confeccionados a temperaturas de 90 e $130^{\circ} \mathrm{C}$, com 10 e $20 \%$ de resina polimérica bicomponente. Todas as amostras foram feitas em pastilhas de $\mathrm{KBr}$, onde se depositou um filme líquido fino. Essas análises foram feitas utilizando-se o espectrofotômetro de infravermelho da BOMEM Hartmann \& Braun MB-series, com resolução de $4 \mathrm{~cm}^{-1}$, como mostra Figura 3.19. 


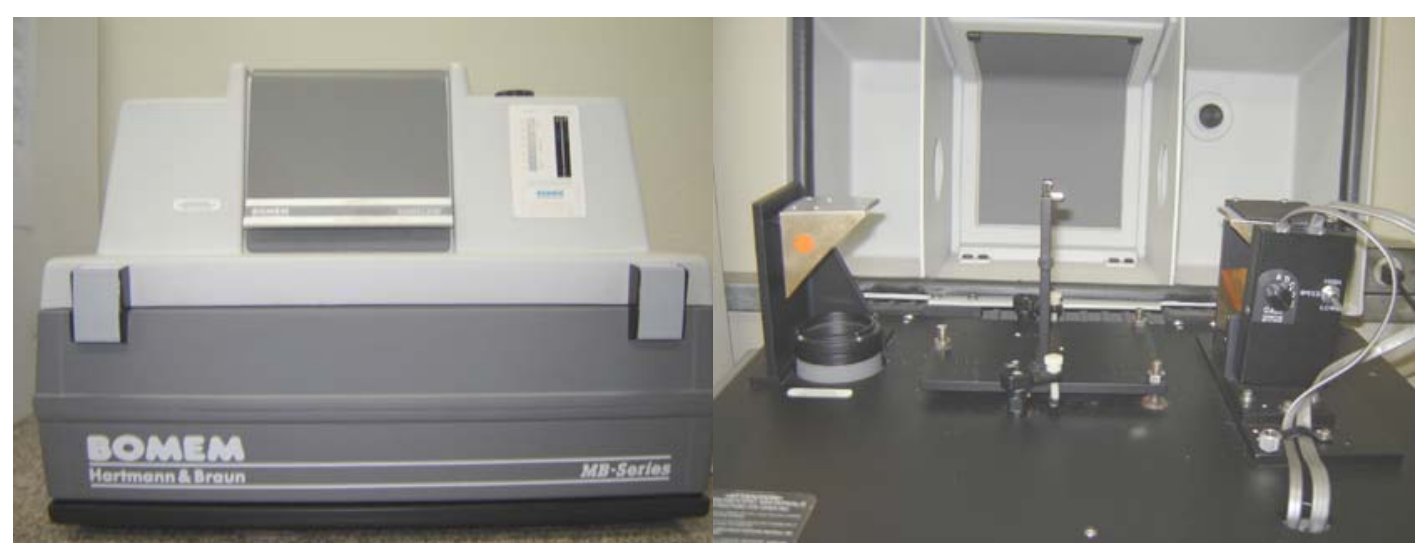

Figura 3.19. Equipamento de espectroscopia de absorção em infravermelho (IQSC/USP)

As placas foram esquadrejadas nas dimensões 350mm x 350mm x 13mm, depois cortadas, como corpos-de-prova, para ensaios das propriedades físicas e mecânicas, de acordo com a norma EN300 (Norma Européia).

\subsection{Propriedades mecânicas e físicas}

A seguir são comentados os procedimentos executados nos ensaios de umidade, densidade, inchamento, flexão estática, adesão interna e ensaio cíclico (água fervente), de acordo com a norma EN 300/2002.

\subsubsection{Ensaio para determinação da umidade EN-322/2000}

Para a determinação do teor de umidade das chapas devem ser retirados corpos-deprova com um peso mínimo de $20 \mathrm{~g}$, sendo que sua forma e dimensões não têm grande importância. No entanto estes não devem conter partículas livres.

Inicialmente os corpos-de-prova devem ser pesados e, depois, colocados em estufa, a uma temperatura de $(103 \pm 2)^{\circ} \mathrm{C}$, até atingirem uma massa constante, ou seja, quando duas pesagens sucessivas, efetuadas com pelo menos 6 horas de intervalo, não diferem mais de 0,1\% em relação à massa do corpo-de-prova. Depois que os corpos- 
de-prova forem arrefecidos aproximadamente à temperatura ambiente em desumidificador, onde devem ser pesados novamente e o teor de umidade calculado através da equação (3.2):

$$
\begin{aligned}
& H=\frac{m_{v}-m_{s}}{m_{s}} .100 \\
& \mathrm{H}=\text { umidade }(\%) ; \\
& \mathrm{M}_{\mathrm{s}}=\text { massa seca }(\mathrm{g}) ; \\
& \mathrm{M}_{\mathrm{v}}=\text { massa verde ou úmida }(\mathrm{g}) .
\end{aligned}
$$

\subsubsection{Ensaios para a determinação da densidade EN-323/2000}

Para a determinação da densidade das chapas foram retirados das mesmas, corposde-prova de formato quadrado, com os lados medindo $50 \mathrm{~mm}$ nominais. Se necessário, os corpos-de-prova devem ser condicionados até obter-se uma massa constante a uma umidade relativa de $(65 \pm 5) \%$ e a uma temperatura de $(20 \pm 2){ }^{\circ} \mathrm{C}$. Considera-se massa constante quando os resultados de duas pesagens sucessivas, efetuadas com pelo menos 24 horas de intervalo, não diferem mais de $0,1 \%$ em relação à massa do corpo-de-prova.

Os corpos-de-prova devem ser inicialmente pesados e ter sua espessura t medida no ponto de encontro de suas diagonais. Deve-se medir $b_{1}$ e $b_{2}$, em 2 pontos, paralelamente às bordas do corpo-de-prova, ao longo das linhas que passam pelo centro das bordas opostas. A densidade é calculada através da equação (3.3):

$$
\begin{aligned}
& \rho=\frac{m}{b_{1} \cdot b_{2} \cdot t} \cdot 10^{6} \\
& \mathrm{~m}=\text { massa }(\mathrm{g}) ; \\
& \mathrm{t}=\text { espessura }(\mathrm{mm}) . \\
& \mathrm{b}_{1} \text { e } \mathrm{b}_{2}=\text { dimensões das bordas }(\mathrm{mm}) .
\end{aligned}
$$




\subsubsection{Determinação do ensaio de inchamento em espessura 24h, EN-317/1993}

Para a determinação de inchamento em espessura, após a imersão das chapas em água destilada por $24 \mathrm{~h}$, devem ser retirados das mesmas corpos-de-prova de formato quadrado com (50 \pm 1$)$ mm de aresta.

Devem ser medidas as espessuras dos corpos-de-prova na intersecção das diagonais antes e após a sua imersão em água limpa, com pH $7 \pm 1$ e temperatura de $20 \pm 1{ }^{\circ} \mathrm{C}$ e estes devem permanecer cobertos por $25 \pm 5 \mathrm{~mm}$ de água durante $24 \mathrm{~h}$. $\mathrm{O}$ inchamento em espessura dado em percentagem é calculado através da equação (3.4):

$$
G_{t}=\frac{t_{2}-t_{1}}{t_{1}} .100
$$

$\mathrm{G}_{\mathrm{t}}=$ inchamento em espessura 24h (\%);

$\mathrm{t}_{1}=$ espessura inicial $(\mathrm{mm})$;

$\mathrm{t}_{2}=$ espessura final após 24h (mm).

Para obter-se um resultado mais preciso de ensaios, foi projetado e construído, durante esta tese, um controlador de pressão hidrostática, para ensaio de inchamento em espessura.
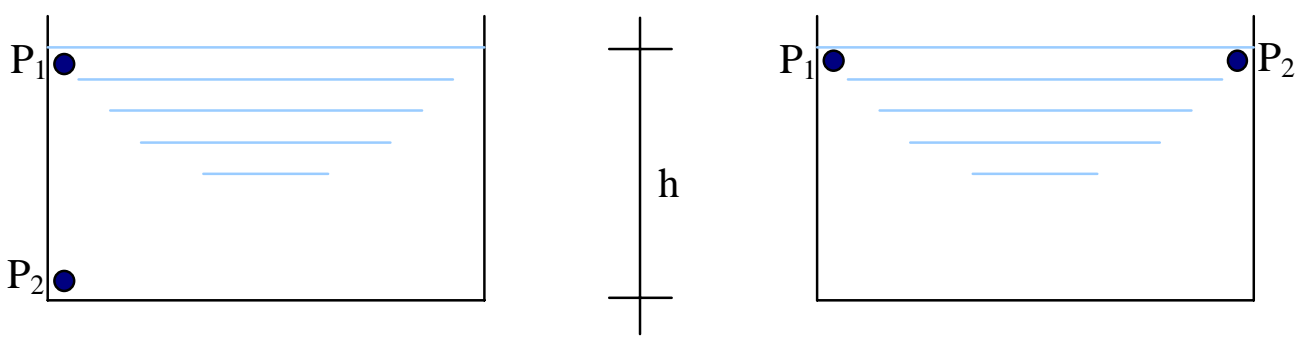

Figura 3.20. Projeto do regulador de pressão desenvolvido durante esta tese no LaMEM

Este controlador hidrostático tem a função de evitar variações nos resultados estatísticos de todos os materiais submetidos a ensaio de absorção em água e inchamento em espessura, não deixando que corpos-de-prova tenham 
comportamentos de aleatoriedade (corpo-de-prova de densidade diferente terá pressão hidrostática diferente, com aleatoriedade) e fixando todos a uma mesma coluna de pressão hidrostática, cujo objetivo é diminuir as variáveis de degradação na imersão dos corpos-de-prova, buscando um menor desvio padrão entre os corposde-prova submetidos ao ensaio e evitando coluna de liquido diferente que pode ocasionar um resultado fora da normalidade.

A figura 3.21 mostra o controlador de pressão hidrostática para ensaio de inchamento em espessura em laboratório.

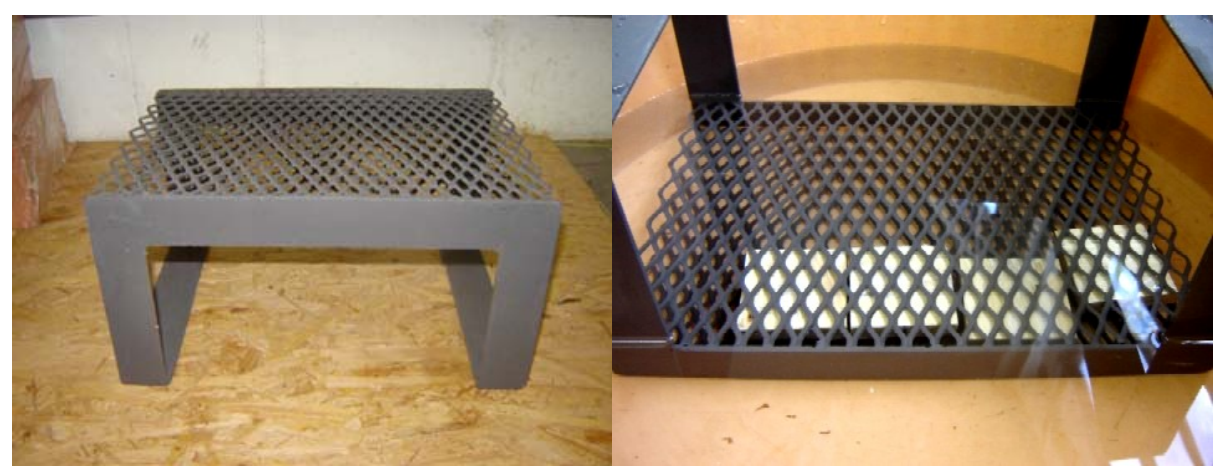

Figura 3.21. Equipamento controlador de pressão hidrostática

Este equipamento traz uma melhor resolução e precisão nos resultados dos ensaios e inchamento em espessura em se tratando de coeficiente de variação entre corpos-deprova.

\subsubsection{Adesão interna pela EN-319/1993}

Para a determinação da resistência à adesão interna (AI) dos painéis, devem ser retirados, dos mesmos, corpos-de-prova de formato quadrado, com (50 \pm 1$) \mathrm{mm}$ de aresta.

São colados suportes de metal ou madeira nas duas faces dos corpos-de-prova que, posteriormente, são tracionados em direções opostas, de forma que os mesmos se rompam. A adesão interna (AI) é calculada através da Equação (3.5). 


$$
\mathrm{AI}=\frac{\mathrm{F}_{\text {max }}}{\mathrm{S}}
$$

Onde,

$\mathrm{AI}=$ Adesão Interna $(\mathrm{MPa})$

$\mathrm{F}_{\max }=$ força máxima $(\mathrm{N})$;

$\mathrm{a}=$ comprimento do corpo-de-prova (mm);

$\mathrm{b}=$ largura do corpo-de-prova (mm).

Sendo a área de adesão $\mathrm{S}$ = a x b.

\subsubsection{Ensaio de adesão interna em água fervente pela EN-1087-1/1995}

A EN 1087-1/1995 aplica-se a placas com sistema de colagem baseado em colas fenólicas de endurecedor alcalino e em colas de isocianato PMDI. O ensaio em água fervente é utilizado para a verificação de conformidade, a fim de controlar a qualidade da colagem obtida por estes sistemas de colagem aprovados. Esta norma é aplicada tomando o seguinte procedimento:

- Colocar em água fervente os corpos-de-prova e retirá-los após o tempo de

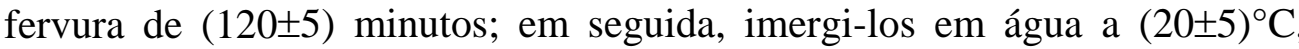
durante $(60 \pm 5)$ minutos. Colocar os corpos-de-prova com suas faces na vertical e afastá-los, uns dos outros, de pelo menos $15 \mathrm{~mm}$, bem como dos lados e do fundo do recipiente.

- Retirar os corpos-de-prova da água e secá-los com papel absorvente.

- Colocá-los na estufa com circulação de ar capaz de manter uma temperatura interior de $(60 \pm 2)^{\circ} \mathrm{C}$, durante $(960 \pm 15)$ minutos, com suas faces na horizontal.

- Em seguida, retirar os corpos-de-prova da estufa; deixá-los esfriar até, aproximadamente, a temperatura ambiente; colar as placas de ensaio nas 
faces dos corpos-de-prova. Se a superfície for rugosa ou desnivelada, pode ser retificada, antes da colagem das placas de ensaio, através de lixa $n^{\circ} 180$, 240 e 320, colocada numa superfície plana.

\subsubsection{Ensaio de flexão para determinação do Módulo de elasticidade (MOE) e Módulo de resistência à Flexão Estática (MOR) na norma EN-310/2000}

Para a determinação do módulo de elasticidade (MOE) e resistência (MOR) à flexão estática das chapas, devem ser retirados das mesmas corpos-de-prova de formato retangular, com a largura (b) igual a $(50 \pm 1) \mathrm{mm}$. O comprimento $\left(l_{2}\right)$ deve ser igual a 20 vezes a espessura nominal mais $50 \mathrm{~mm}$, com um comprimento máximo de 1050mm e um mínimo de 150mm. A espessura deve ser medida no ponto de interseção das diagonais e a largura, na metade do comprimento.

A amostragem e o corte dos corpos-de-prova devem ser efetuados de acordo com as prescrições do documento normativo EN 326-1/1994, sendo necessárias séries de corpos-de-prova nas duas direções, longitudinal e transversal.

Os mesmos devem ser condicionados até o peso constante, sob umidade relativa de $(65 \pm 5) \%$ e uma temperatura de $(20 \pm 2)^{\circ} \mathrm{C}$, sendo que se considera peso constante quando os resultados de duas pesagens sucessivas, efetuadas com pelo menos 24 horas de intervalo, não diferem mais de $0,1 \%$ em relação ao peso inicial do corpode-prova.

Os corpos-de-prova devem ser biapoiados, a força deve ser aplicada pontualmente e o instrumento utilizado para medir a flecha deve ter sensibilidade de 0,1 mm.

Regula-se a distância entre os centros de apoio, de 20 vezes a espessura nominal da placa, sem que ela seja inferior a $100 \mathrm{~mm}$ e superior a $1000 \mathrm{~mm}$ e mede-se a distância entre os centros de apoio, com a aproximação de 0,5 mm. 
Colocam-se os corpos-de-prova na horizontal, sobre os apoios, com o seu eixo longitudinal perpendicular aos eixos dos apoios com o ponto central sobre a força. Aplica-se a força à velocidade constante e regula-se a velocidade do ensaio de modo que a força de ruptura seja atingida em $(60 \pm 30) \mathrm{s}$.

Mede-se a flecha no ponto médio do vão do corpo-de-prova, em função das forças correspondentes medidas com uma precisão de $1 \%$ do valor medido. Se a flecha for determinada por leituras sucessivas, utilizar pelo menos seis pares de leitura. Registra-se a força de ruptura com precisão de $1 \%$ do valor medido.

Os ensaios são efetuados sobre dois grupos de corpos-de-prova retirados segundo as duas direções da placa, isto é, segundo o sentido longitudinal e o transversal. Em cada grupo, ensaia-se metade dos corpos-de-prova com a face superior para cima e a outra, com a face inferior para cima.

O Módulo de Elasticidade na flexão estática (MOE) é calculado através da equação (3.6). Para cada grupo de corpos-de-prova tirados de um mesmo painel, ele consiste na média aritmética dos módulos de elasticidade na flexão dos corpos-de-prova considerados e deve ser expresso com três algarismos significativos.

$$
M O E=\frac{l_{1}^{3}\left(F_{2}-F_{1}\right)}{4 b t^{3}\left(a_{2}-a_{1}\right)}
$$

$l_{1}=$ distância entre os centros dos apoios (mm);

$b=$ largura do corpo-de-prova (mm);

$\mathrm{t}$ = espessura do corpo-de-prova (mm);

$F_{2}-F_{1}=$ incremento de força, em Newton, na seção retilínea da curva força-flecha, onde $F_{1}$ deve ser cerca de $10 \%$ e $F_{2}$ cerca de $40 \%$ da força de ruptura;

$a_{2}-a_{1}=$ incremento da flecha correspondente a $F_{2}-F_{1}$. 
A resistência à flexão (MOR) de cada corpo-de-prova, dada em N/mm² ou MPa, é calculada pela Equação (3.7). Para cada grupo de corpos-de-prova retirados da mesma placa, ela consiste na média aritmética das resistências à flexão dos corposde-prova considerados e é expressa com três algarismos significativos.

$$
M O R=\frac{3 F_{\max } l_{1}}{2 b t^{2}}
$$

$F_{\max }=$ força de ruptura $(\mathrm{N})$;

$l_{1}=$ distância entre os centros dos apoios (mm);

$b=$ largura do corpo-de-prova (mm);

$t=$ espessura do corpo-de-prova (mm).

A chapa OSB, como todo produto, está sujeito à classificação, que contribui para dar aplicação de uso com seus requisitos.

A norma EN 300-2000 é exclusiva para produtos OSB derivados de madeira. A utilização desta norma neste trabalho é devido à ausência de norma na forma deste produto para o bagaço de cana e sendo este documento de norma o mais adequado para desenvolver o produto em tese (Anexo 1: Tabelas da Norma EN 300/2002). 


\section{RESULTADOS E DISCUSSÃO}

Apresentam-se neste capítulo os resultados e as discussões obtidas no trabalho: análise térmica do bagaço de cana, para verificar possível temperatura de prensagem; teor de extração; espectroscopia de absorção na região de infravermelho; microscopia eletrônica de varredura; propriedades físicas e mecânicas do material baseado na norma EN 300/2002; teste de normalidade.

\subsection{Características térmicas}

Depois de coletado, estudado e preparado, o material foi submetido à análise térmica para verificar a temperatura máxima de trabalho.

$\mathrm{Na}$ análise de características térmicas, levam-se em consideração as características do bagaço de cana-de-açúcar e da resina poliuretana à base de mamona aplicada.

Para o bagaço de cana, foi levantada uma curva termogravimétrica, por meio da qual se verificou a variação da massa analisada em função do tempo ou da temperatura, com velocidade na razão de aquecimento em torno de $10^{\circ} \mathrm{C} / \mathrm{min}$, variando desde a temperatura ambiente até a temperatura de $375^{\circ} \mathrm{C}$. Esta razão de aquecimento é suficiente para estabelecer um padrão de curva com melhor resolução, em atmosfera de nitrogênio ou de oxigênio, como mostra a figura 4.1 . 


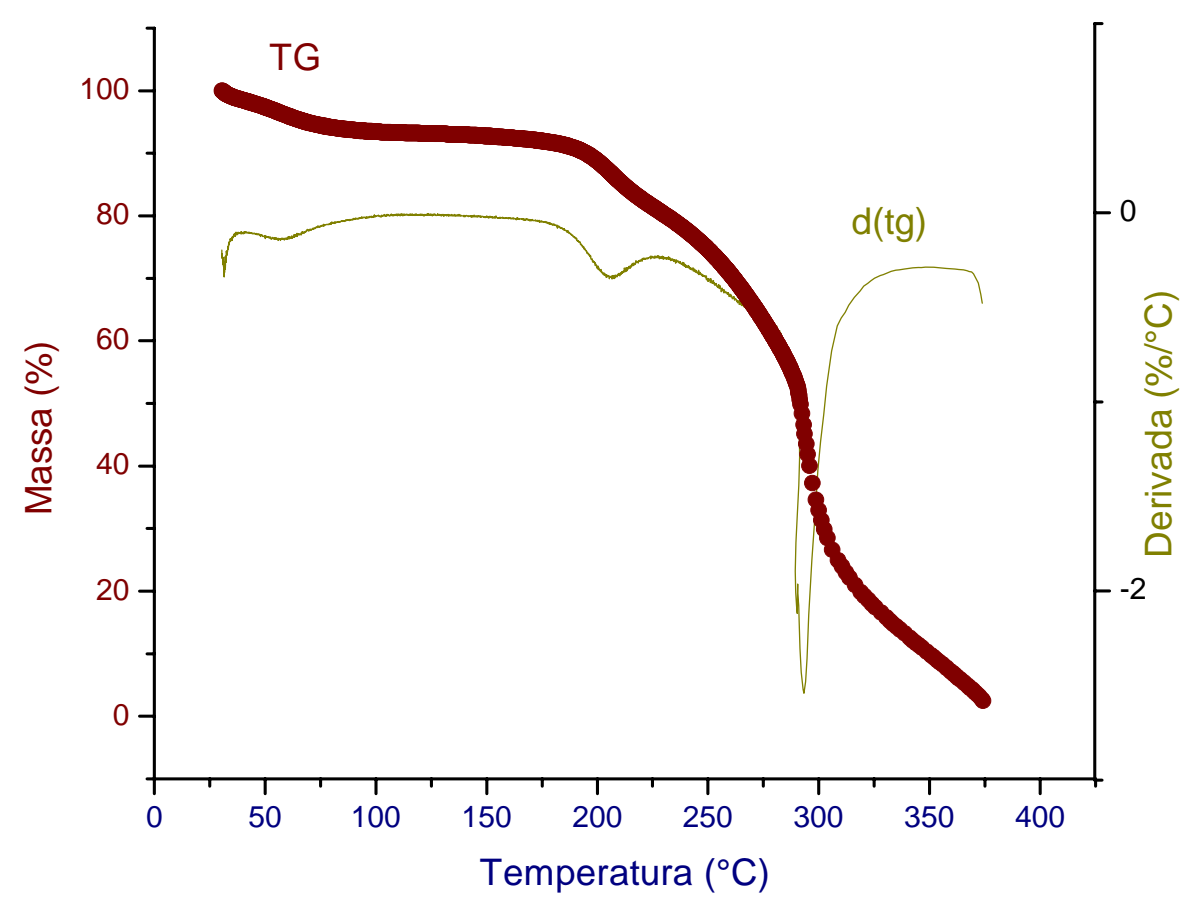

Figura 4.1. Curva de decomposição do bagaço de cana-de-açúcar

Verificou-se o comportamento adequado desde a temperatura ambiente até $60^{\circ} \mathrm{C}$, considerada como patamar de secagem sem perda de propriedades. Acima desta temperatura, ocorre a perda de água livre até $75^{\circ} \mathrm{C}$; depois deste ponto, verifica-se o início de uma reação, em torno dos $100^{\circ} \mathrm{C}$; logo após, tem o início da perda de água de decomposição, próxima de $125^{\circ} \mathrm{C}$; desta temperatura até $170^{\circ} \mathrm{C}$, considera-se como sendo o intervalo de trabalho a quente; observa-se o início da decomposição da estrutura do bagaço, a $175^{\circ} \mathrm{C}$, sendo que, a $200^{\circ} \mathrm{C}$, inicia-se o processo de queima total do resíduo.

Para comparação com a resina à base de mamona, optou-se pelo emprego da resina Cascomel M 08 ME, de circulação comercial, na fabricação de painéis de partículas de bagaço de cana, longas e orientadas.

Com base nestas informações, neste trabalho adotou-se a temperatura de prensagem entre 90 e $130^{\circ} \mathrm{C}$. A primeira é considerada a temperatura ideal para a resina 
poliuretana à base do óleo de mamona e a segunda é a temperatura de prensagem da resina Cascomel M 08 ME. Essas temperaturas se encontram dentro dos padrões térmicos aceitáveis para relação bagaço/resinas.

A Cascomel M-08-ME é uma resina à base de Melamina-Uréia-Formol, em solução aquosa, desenvolvida para a fabricação de painéis derivados de madeira, como MDF e OSB.

A tecnologia utilizada no desenvolvimento da Cascomel M-08-ME ofereceu um produto com as características técnicas apresentadas a seguir.

\begin{tabular}{|c|c|}
\hline CARACTERÍSTICAS CASCOMEL N & $08 \mathrm{ME}$ \\
\hline 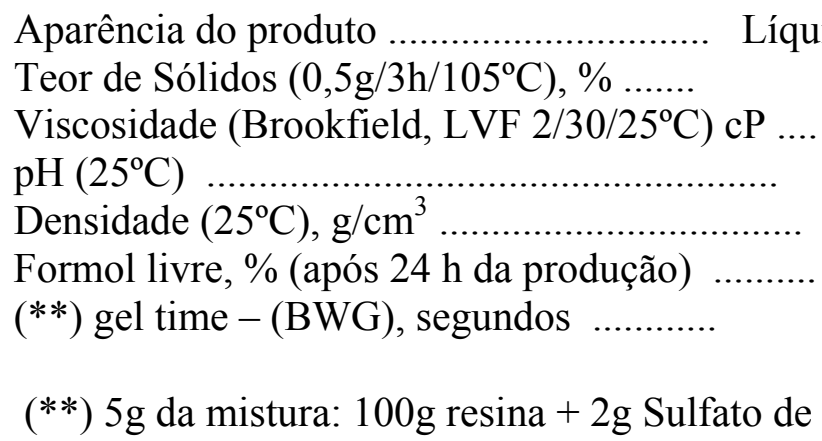 & $\begin{array}{l}\text { do, branco leitoso } \\
\qquad \begin{array}{c}65-67 \\
150-210 \\
7,5-8,0 \\
1,2825-1,2945 \\
\text { Máximo } 0,3 \\
50-80\end{array} \\
\text { Amônio P.A. }\end{array}$ \\
\hline
\end{tabular}

Fonte: Hexion (cascomel M-08-ME)

A Cascomel M-08-ME não está classificada como produto perigoso, conforme Dec. 96.044 de 18/05/88 e Portaria 204 de 26/05/97.

Algumas características da resina poliuretana à base de mamona descrita a seguir.

\begin{tabular}{|lr|}
\hline CARACTERÍSTICAS MAMONA & Poliol/Pré-polímero \\
\hline & \\
Aparência do produto & Líquido oleoso, Amarelo \\
Teor de Sólidos $\left(0,5 \mathrm{~g} / 3 \mathrm{~h} / 105^{\circ} \mathrm{C}\right), \% \ldots \ldots . .$. & $0 / 0$ \\
Viscosidade $\left(\right.$ Cent poise $\left./ 25^{\circ} \mathrm{C}\right)$ & $(700-1000) /(50-100)$ \\
$\mathrm{pH}\left(25^{\circ} \mathrm{C}\right)$ & $5 / 4$ \\
Densidade $\left(25^{\circ} \mathrm{C}\right), \mathrm{g} / \mathrm{cm}^{3}$ & $0,9 / 1,2$ \\
Formol livre, $\%($ após $24 \mathrm{~h}$ da produção) & Máximo 0,1 \\
$(* *)$ gel time $-(\mathrm{BWG})$, minutos & $5-20$ \\
& \\
\hline
\end{tabular}

Fonte: IQSC 


\subsection{Espectroscopia de absorção na região do infravermelho}

Justifica-se a utilização desta análise, devido a substâncias livres que poderiam ocasionar problemas de saúde num eventual uso comercial desta resina.

As análises de infravermelho foram feitas no pré-polímero, no poliol, nos painéis de partículas longas e orientadas de bagaço da cana-de-açúcar: partículas longas com $10 \%$ de resina de mamona a $90^{\circ} \mathrm{C}$, partículas longas e orientadas com $10 \%$ de resina de mamona a $130^{\circ} \mathrm{C}$, partículas longas e orientadas com $20 \%$ de resina de mamona a $90^{\circ} \mathrm{C}$. Esses resultados foram obtidos após 48 horas da mistura do poliol no prépolímero nos painéis, conforme mostra a Figura 4.2.

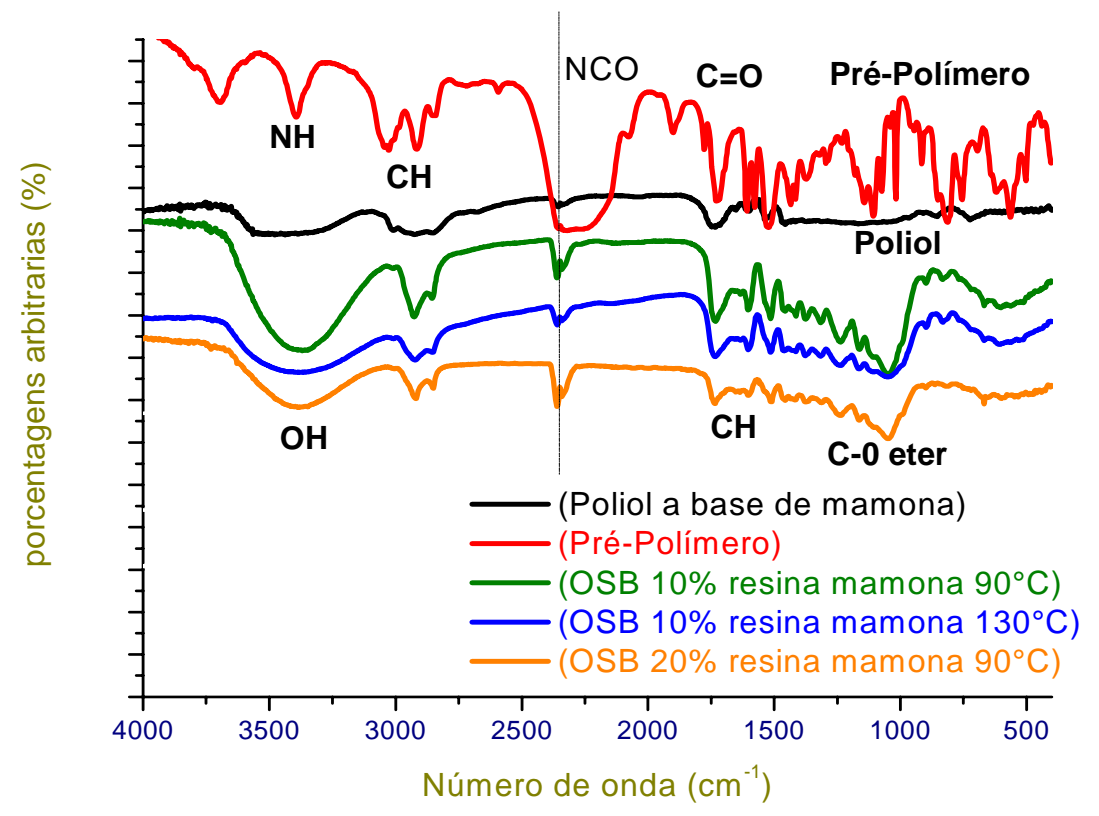

Figura 4.2. Espectro de infravermelho do pré-polímero, poliol, painel de partículas longas e orientadas de bagaço com $10 \%$ resina mamona a $90^{\circ} \mathrm{C}$ e $130^{\circ} \mathrm{C}$, e partículas longas e orientadas com $20 \%$ resina mamona a $90^{\circ} \mathrm{C}$

O poliol é um poliéster derivado do óleo de mamona, sendo observado seu espectro (figura 4.2), na cor preta. Já no poliol, a banda característica de grupos carbonila $\mathrm{CH}$ está localizada na região próxima de $1730 \mathrm{~cm}^{-1}$ e a de grupos hidroxila $\mathrm{OH}$, na região 
próxima de $3370 \mathrm{~cm}^{-1}$. A presença de duas bandas de absorção na região entre, aproximadamente, $3050 \mathrm{~cm}^{-1}$ e $2770 \mathrm{~cm}^{-1}$ está relacionada aos estiramentos simétricos e assimétricos da ligação C-H com a carbonila. No pré-polímero, cujo espectro é representado na cor vermelha, observou-se a banda característica do grupo isocianato, na região entre $2250 \mathrm{~cm}^{-1}$ e $2300 \mathrm{~cm}^{-1}$, e as bandas de uretana que foram pré-polimerizadas, nas regiões próximas de 1750, 1620, 1508 e $1420 \mathrm{~cm}^{-1}$, estando relacionadas aos estiramentos $\mathrm{C}=\mathrm{O}$ e $\mathrm{N}-\mathrm{H}$.

Os espectros nas cores, verde, azul e laranja representam o processo de polimerização e são mostrados na mesma figura, junto com o bagaço em forma de painel de partículas longas e orientadas de bagaço de cana-de-açúcar. Após 48 horas e início da polimerização, esses espectros apresentaram uma considerada redução na banda de isocianato, na região $2270 \mathrm{~cm}^{-1}$; essa banda vai se reduzindo até a quase total extinção, 48 horas após a mistura. Observou-se também uma mudança de intensidade nas bandas de absorção relacionadas ao estiramento $\mathrm{C}=\mathrm{O}$ e N-H (1750, 1620, 1508 e $\left.1420 \mathrm{~cm}^{-1}\right)$, concluindo a formação da ligação uretana. Nota-se que, apesar de o polímero ter adquirido rigidez após as primeiras horas de formação do painel de partículas longas e orientadas, suas propriedades só serão analisadas depois de 48 horas, para não comprometer os resultados.

Na obtenção do painel de partículas longas e orientadas de bagaço da cana-de-açúcar com resina poliuretana à base de óleo de mamona, concluiu-se não haver contaminação através de isocianato, pois a reação é completa no compósito formado após as 48 horas. 


\subsection{Microscopia Eletrônica de Varredura}

A microscopia eletrônica de varredura irá evidenciar o comportamento de adesão entre as partículas longas de bagaço da cana-de-açúcar e a resina, assim como o estado de orientação das partículas no painel formado. A análise foi feita utilizando equipamento de microscopia eletrônica de varredura TOPCOM modelo SM-300. As amostras foram preparadas, sendo inicialmente lixadas e, logo em seguida, submetidas a um banho com ouro a vácuo, na camada externa, para facilitar a conversão do sinal dos feixes em imagem. Essas análises têm por finalidade observar a topografia superficial das amostras, seus contornos de resíduo/resina, tamanho e disposição das fibras e verificar a compactação de impregnação da resina no resíduo de bagaço de cana-de-açúcar.

Essa técnica utiliza um feixe fino de elétrons que incide na superfície da amostra de bagaço de cana para verificar a anatomia e a disposição da fibra, no seu estado natural, e também nos corpos-de-prova, de partículas longas e orientadas do bagaço de cana com $10 \%$ e com $20 \%$ de resina à base de mamona e com $10 \%$ de resina Cascomel MO 08 ME. Esses feixes de elétrons interagem com o material e os elétrons secundários são coletados por um detector que converte o sinal em imagem, definindo as micrografias das amostras em análise.

Inicialmente foi analisado o bagaço de cana em seu estado primário, ou seja, antes da prensagem, verificando a anatomia do bagaço a ser adicionado, verificando sua região de fibra externa, também denominada "conrimd", onde se observou uma estrutura com fibras compactas, com menor empacotamento entre fibras, dando o aspecto de uma estrutura de alta densidade, que influencia na estrutura de sustentação do caule durante o crescimento dos colmos. De acordo com a micrografia, não foi possível verificar a geometria de empacotamento do tecido fibroso e parenquimatoso, 
mas pode-se, em tese, afirmar que esta estrutura geometricamente seja semelhante ao tecido interno, como mostrado na figura 4.3.

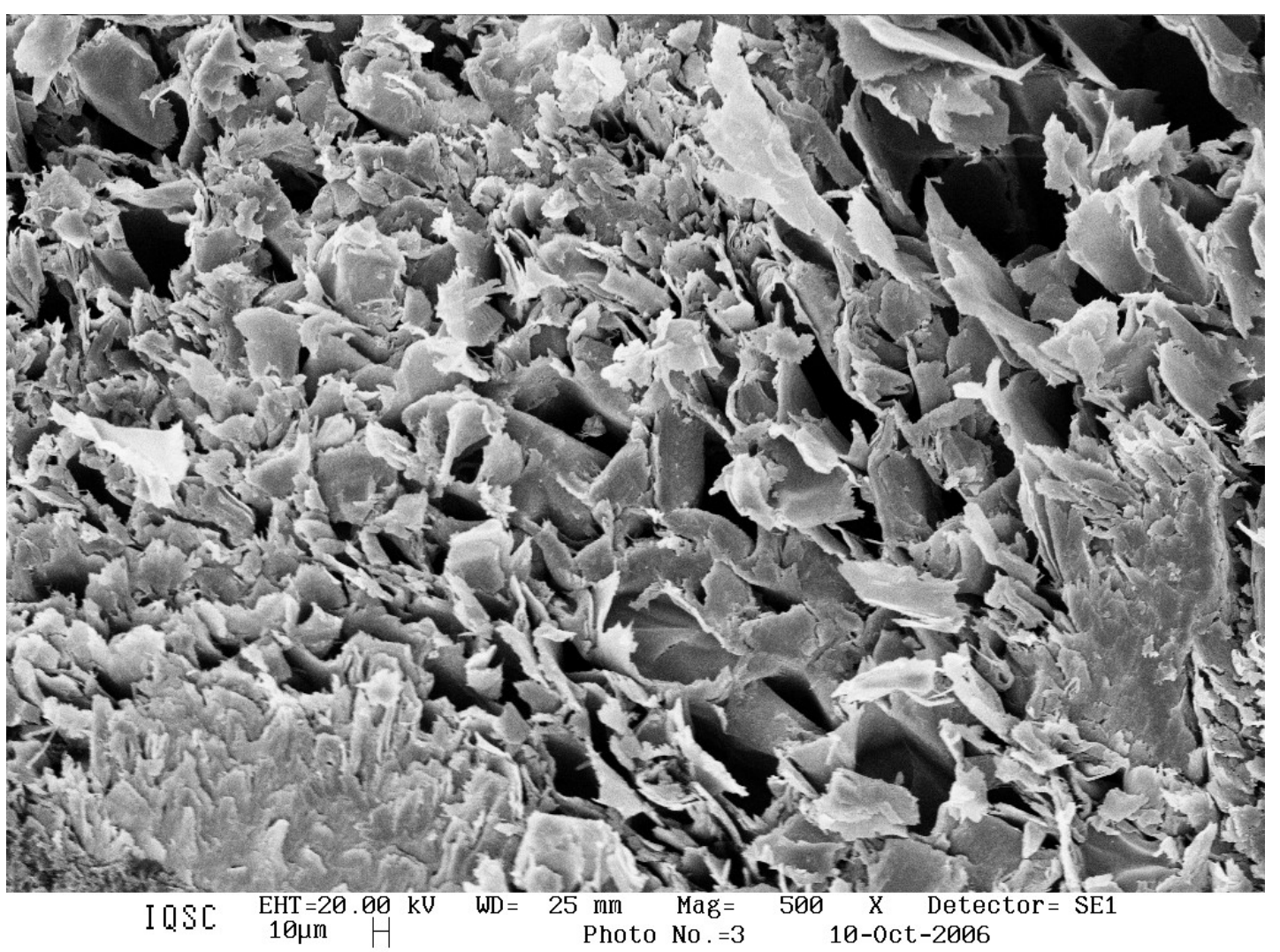

Figura 4.3. Micrografias da região externa do bagaço da cana-de-açúcar em escala $500 \mathrm{x}$

$\mathrm{Na}$ micrografia, observa-se uma estrutura geométrica fibrovascular com tamanho de vasos em torno de $40 \mu \mathrm{m}$. 


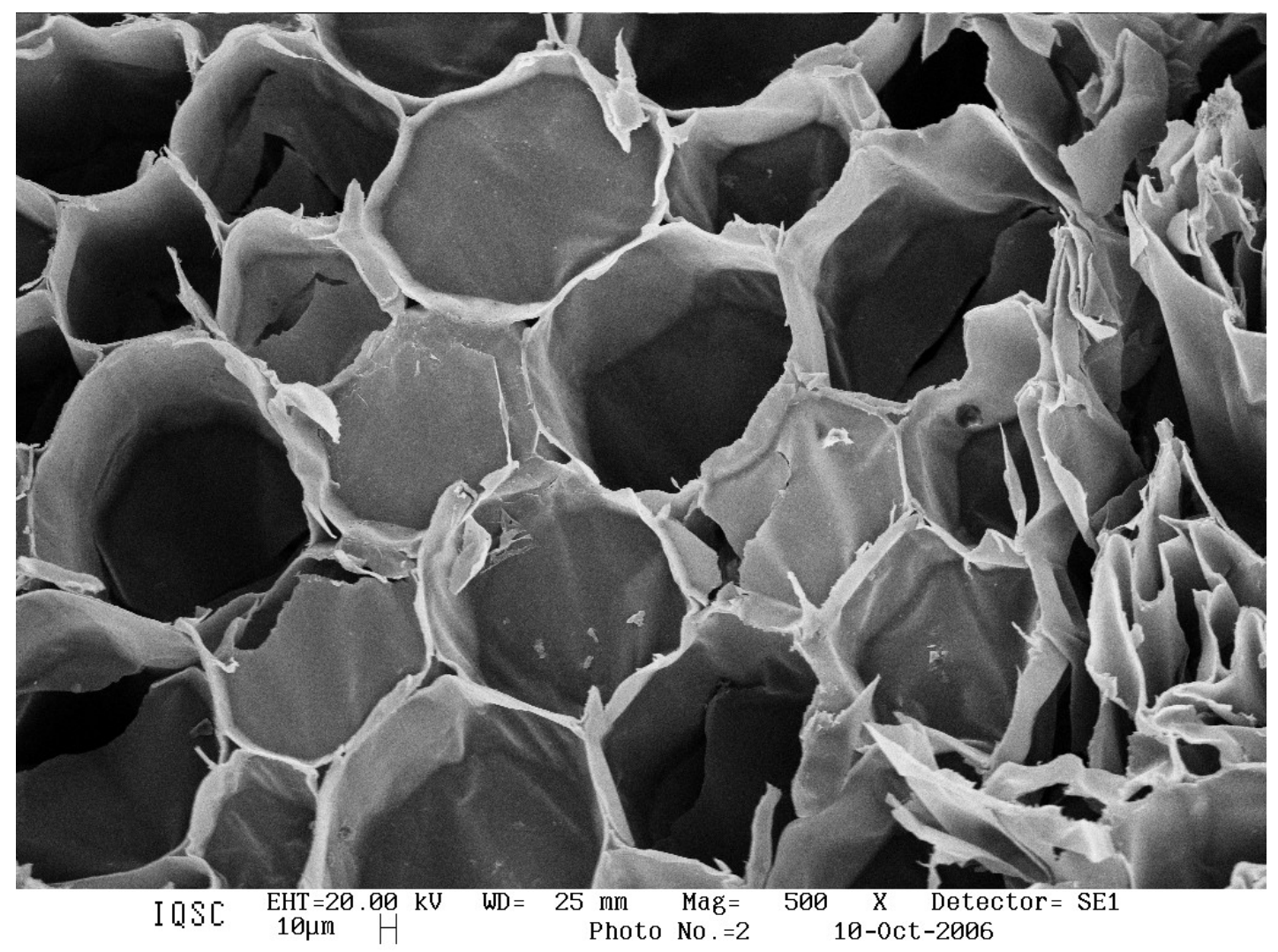

Figura 4.4. Micrografias da região interna do bagaço da cana-de-açúcar em escala $500 x$

$\mathrm{Na}$ parte interna (Figura 4.4), verifica-se a estrutura geométrica fibrovascular em forma de colméia, com tamanho de vaso em torno de $160 \mu \mathrm{m}$, quatro vezes maior que a fibra externa. 


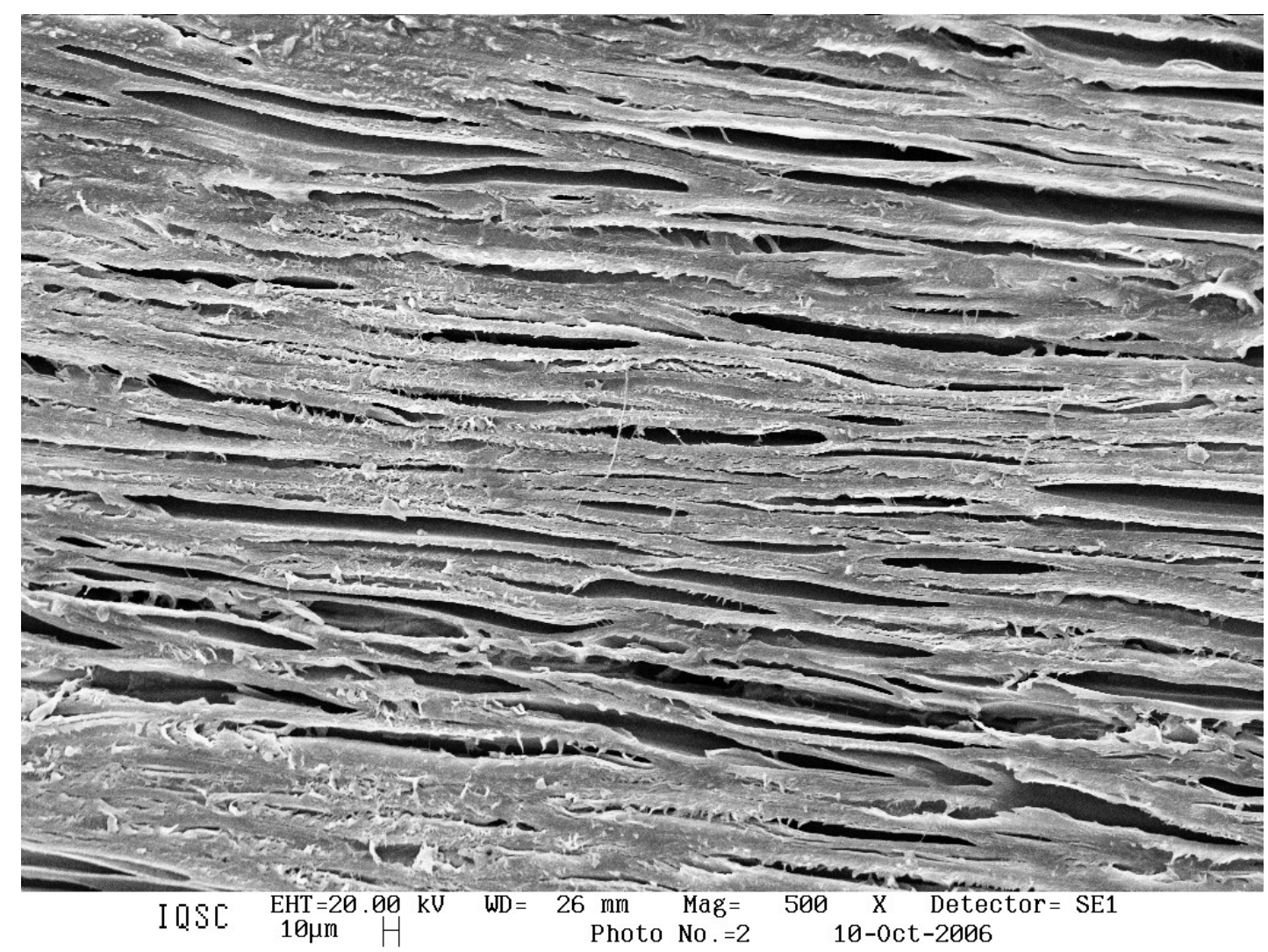

Figura 4.5. Micrografias da região longitudinal do painel de partículas longas de bagaço de cana-de-açúcar, com $10 \%$ de resina à base de mamona e prensado a quente em temperatura de $90^{\circ} \mathrm{C}$ em escala 500x.

Microestrutura da fibra longitudinal mostra microporos entre fibras (Figura 4.5), ocasionados, em tese, pela temperatura de reação e quantidade de resina. 


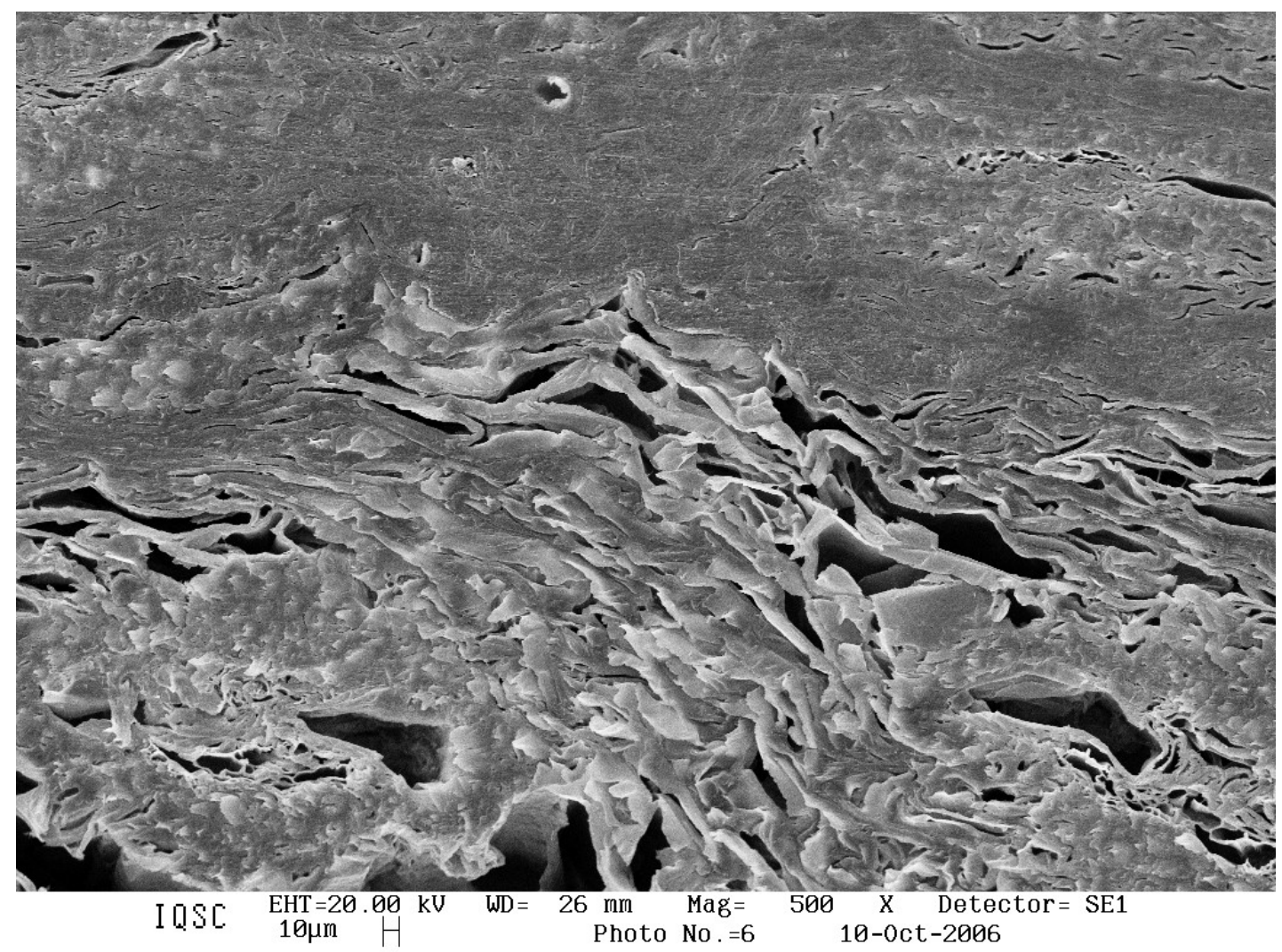

Figura 4.6. Micrografias da região de transição longitudinal/transversal do painel de partículas longas de bagaço de cana-de-açúcar, com $10 \%$ de resina à base de mamona e prensado a quente em temperatura de $90^{\circ} \mathrm{C}$ em escala $500 \mathrm{x}$

$\mathrm{Na}$ figura 4.6, observa-se uma fase de transição com uma microestrutura bem definida e poucos poros. 


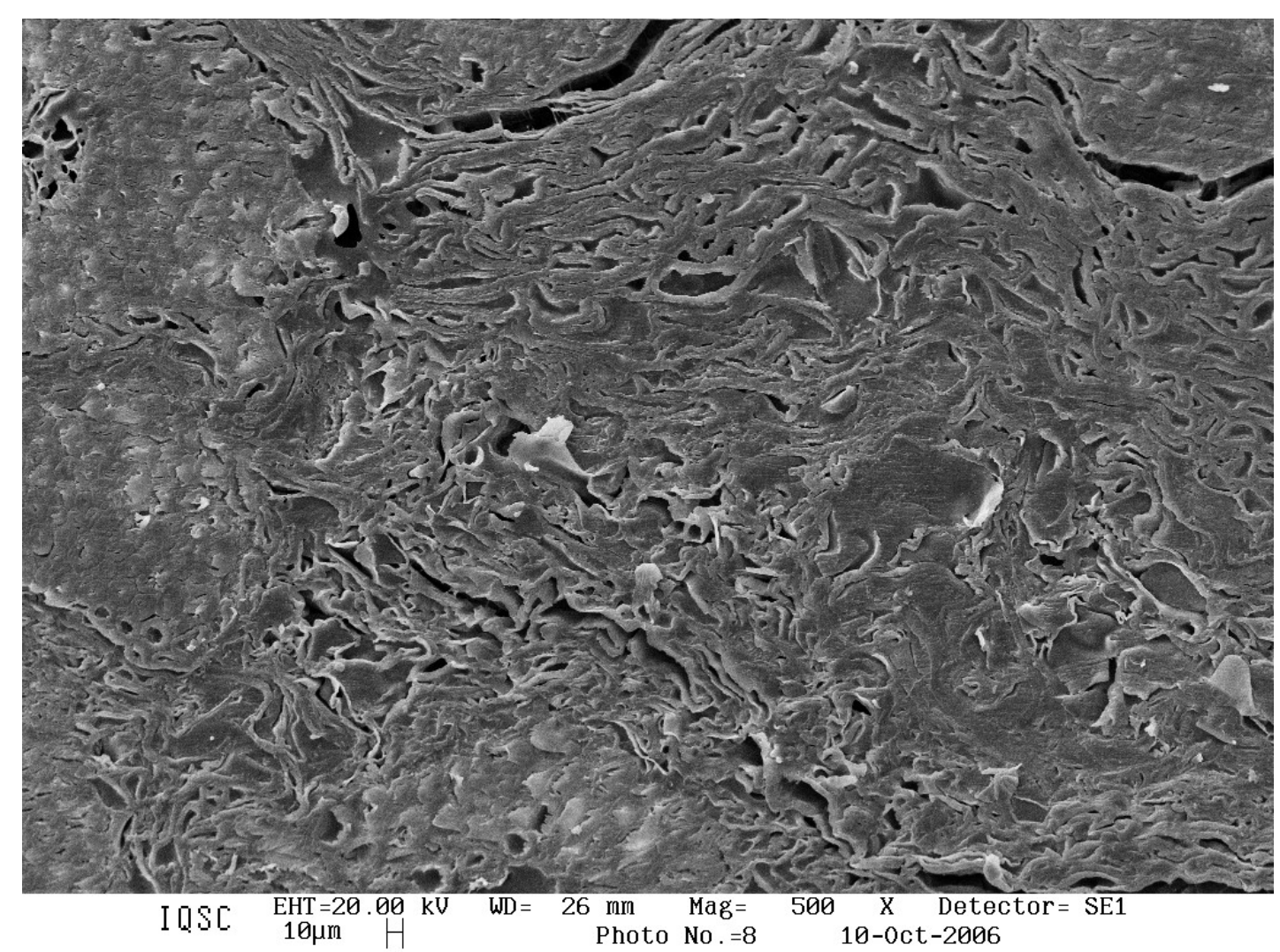

Figura 4.7. Micrografias da região transversal do painel de partículas longas de bagaço de cana-de-açúcar, com $10 \%$ de resina à base de mamona e prensado a quente em temperatura de $90^{\circ} \mathrm{C}$ em escala $500 \mathrm{x}$

A figura 4.7 apresenta uma microestrutura frontal com poucos poros do painel de partículas longas de bagaço de cana-de-açúcar, prensado a quente em $90^{\circ} \mathrm{C}$. 


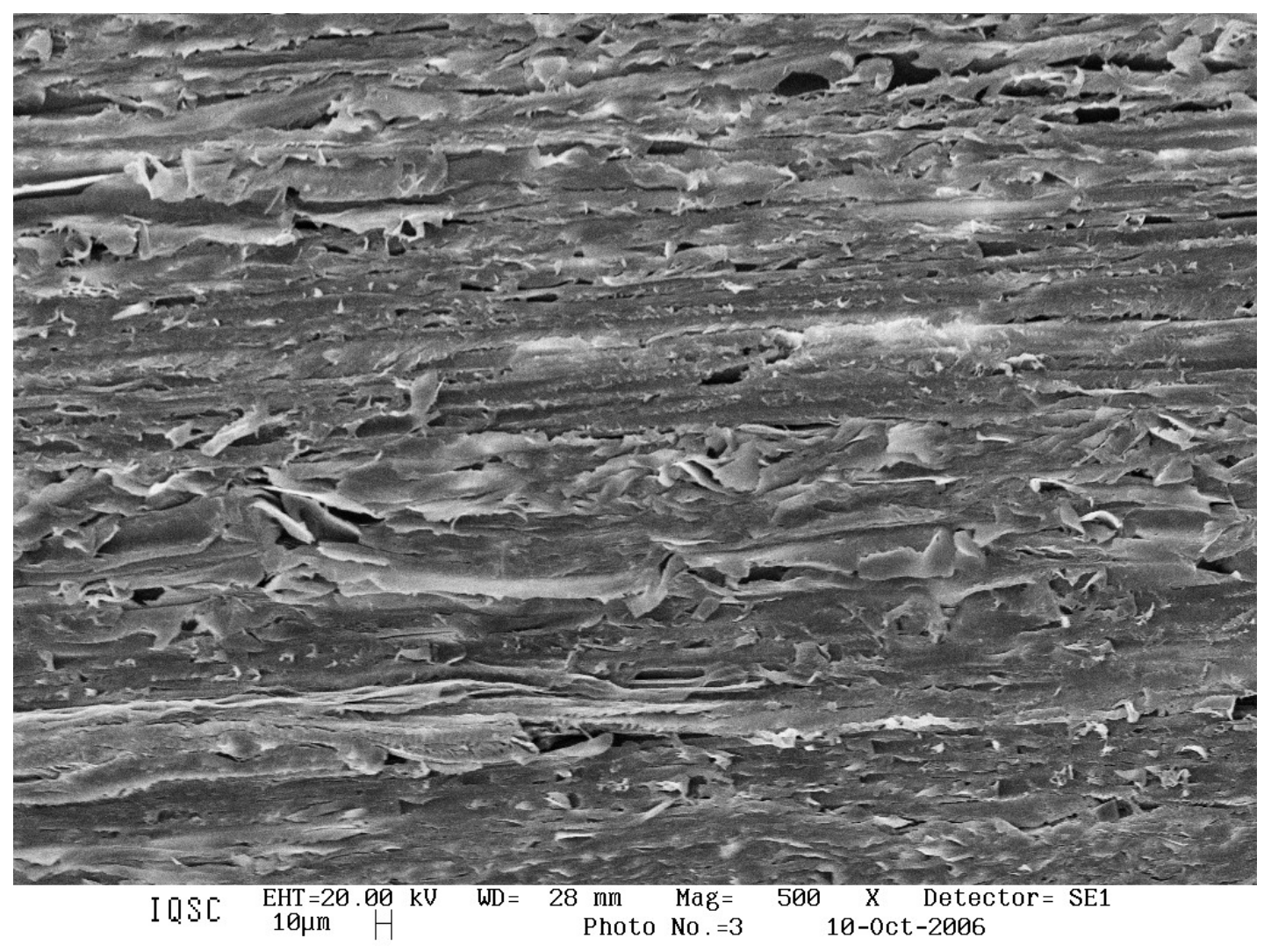

Figura 4.8. Micrografias da região longitudinal do painel de partículas longas de bagaço de cana-de-açúcar, com $10 \%$ de resina à base de mamona e prensado a quente em temperatura de $130^{\circ} \mathrm{C}$ em escala $500 \mathrm{x}$

Analisando a figura 4.8 observa-se uma melhor reação partícula/resina à temperatura de $130^{\circ} \mathrm{C}$ e alto teor de impregnação. 


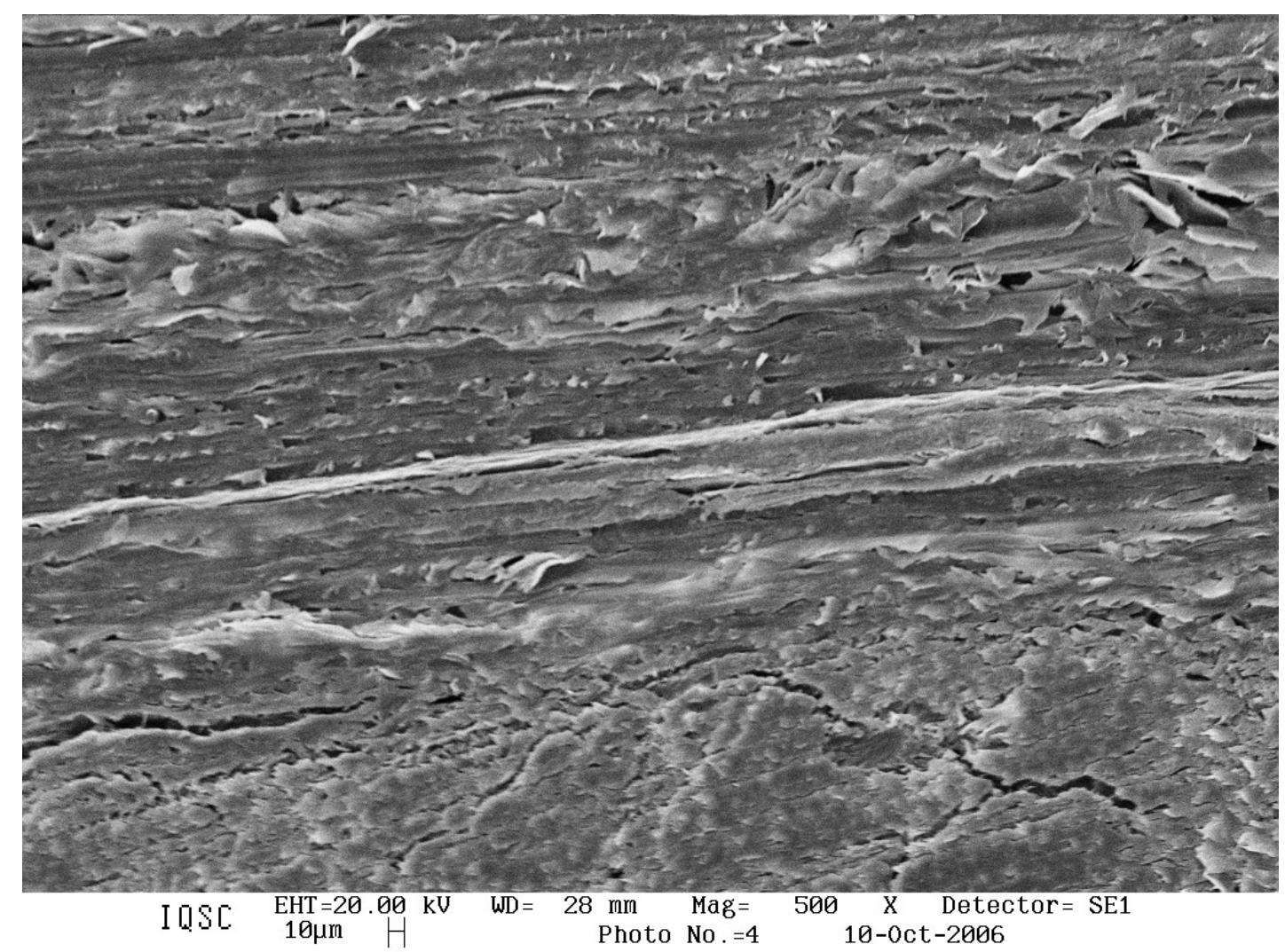

Figura 4.9. Micrografias da região de transição longitudinal/transversal do painel de partículas longas de bagaço de cana-de-açúcar, com $10 \%$ de resina à base de mamona e prensado a quente em temperatura de $130^{\circ} \mathrm{C}$ em escala $500 \mathrm{x}$

Na Figura 4.9 observou-se pequena trinca em conseqüência do tempo de prensagem de 10 minutos ser elevado para esta temperatura. Sugere-se, para futuros trabalhos, uma redução do tempo de prensagem, nesta temperatura. 


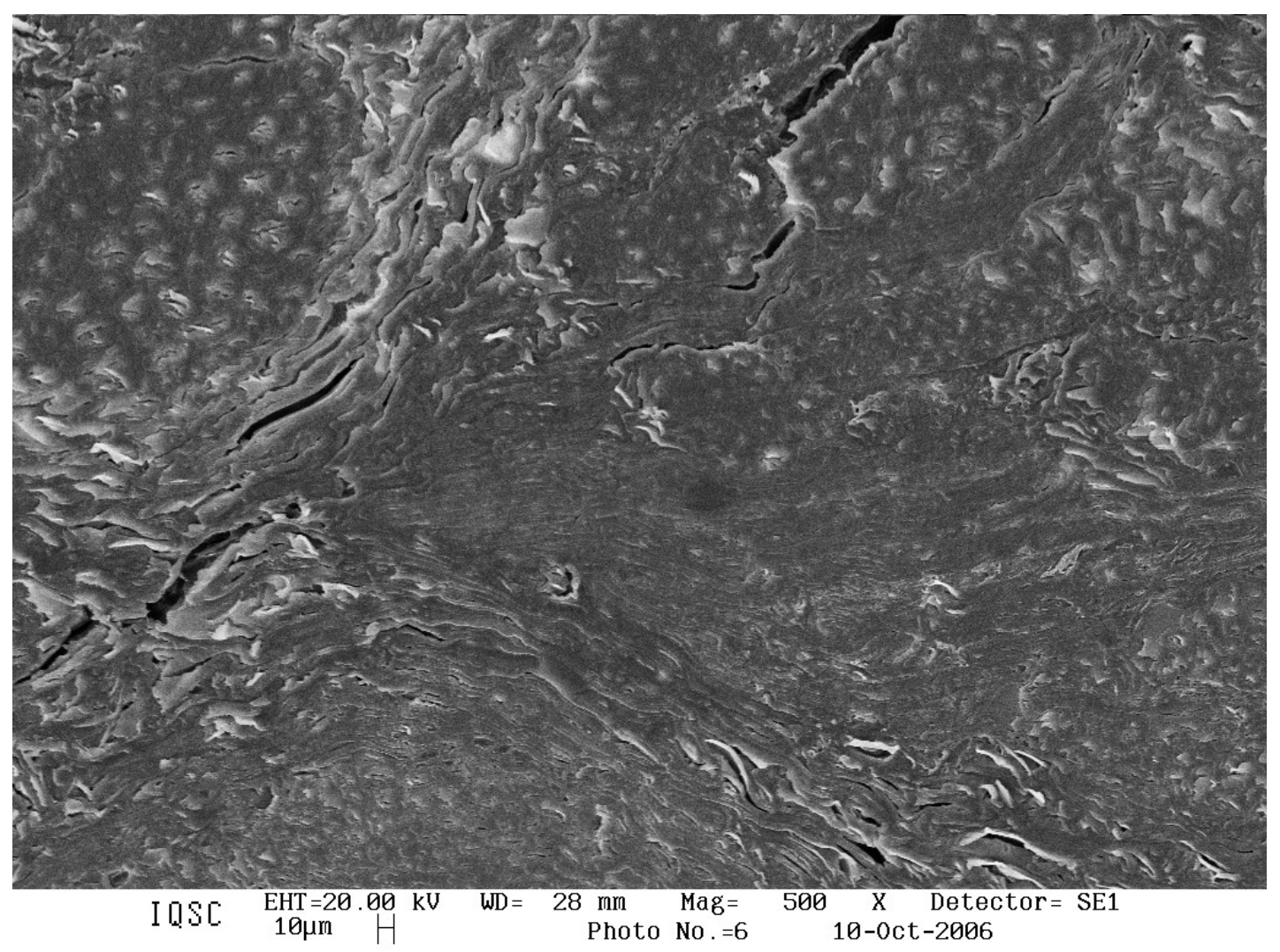

Figura 4.10. Micrografias da região transversal do painel de partículas longas de bagaço de cana-de-açúcar, com $10 \%$ de resina à base de mamona e prensado a quente em temperatura de $130^{\circ} \mathrm{C}$ em escala $500 \mathrm{x}$

A $130^{\circ} \mathrm{C}$, microscopicamente (Figura 4.10), observou-se uma adesão completa da resina polimérica, com aproximadamente $99 \%$ de compactação. 


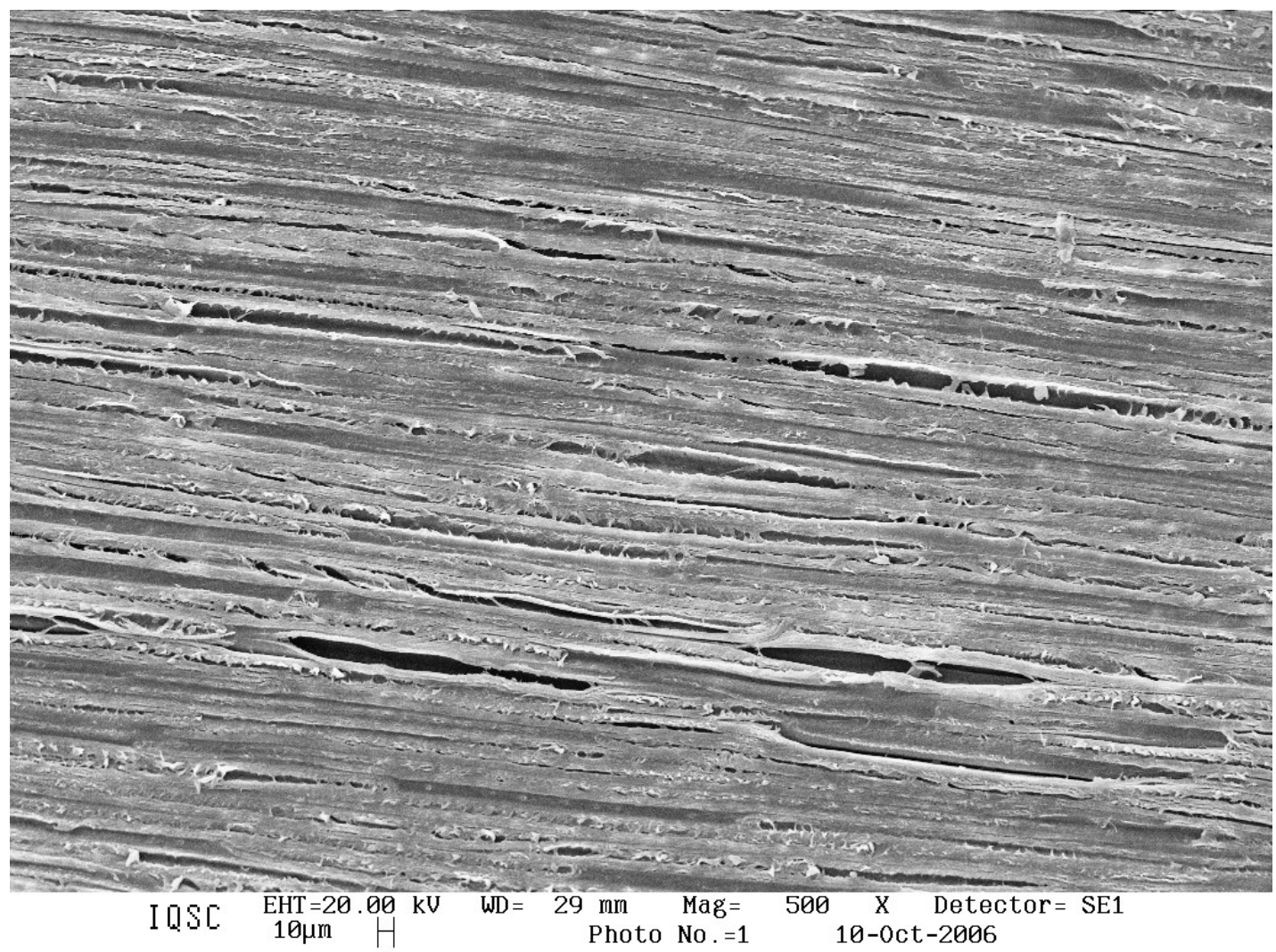

Figura 4.11. Micrografias da região longitudinal do painel de partículas longas de bagaço de cana-de-açúcar, com $10 \%$ de resina à base de Cascomel MO 08 e prensado a quente em temperatura de $130^{\circ} \mathrm{C}$ em escala $500 \mathrm{x}$

Microscopicamente (Figura 4.11) observou-se diferença entre os painéis produzidos com a resina cascomel e a resina à base de mamona. Ressaltando que esta diferença seja devido a presença de poros entre fibra e resina. 


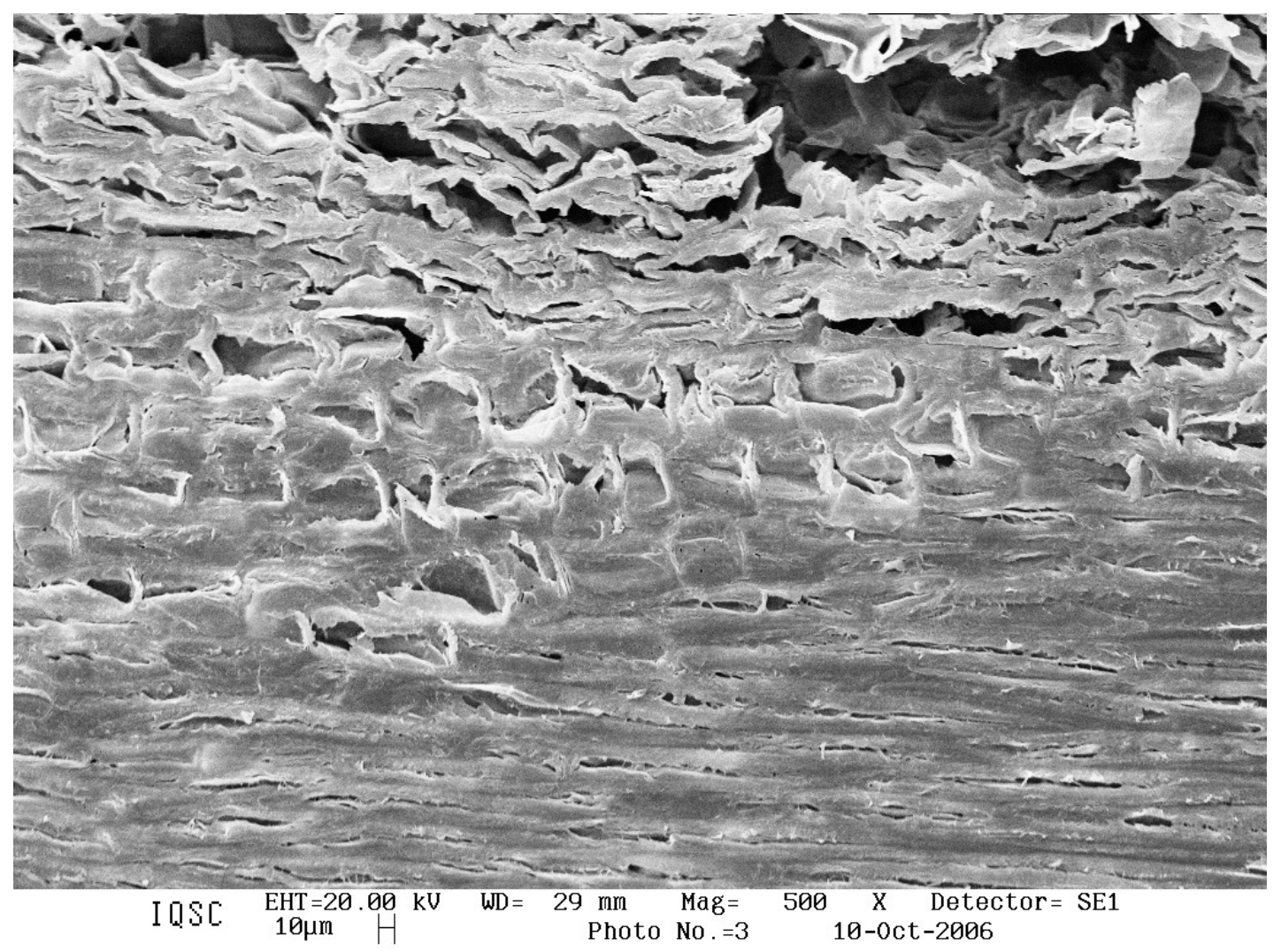

Figura 4.12. Micrografias da região de transição longitudinal/transversal do painel de partículas longas de bagaço de cana-de-açúcar, com $10 \%$ de resina à base de Cascomel MO $08 \mathrm{ME}$ e prensado a quente em temperatura de $130^{\circ} \mathrm{C}$ em escala $500 \mathrm{x}$

A região de transição entre camadas apresenta-se com microporos (Figura 4.12) de forma regular. 


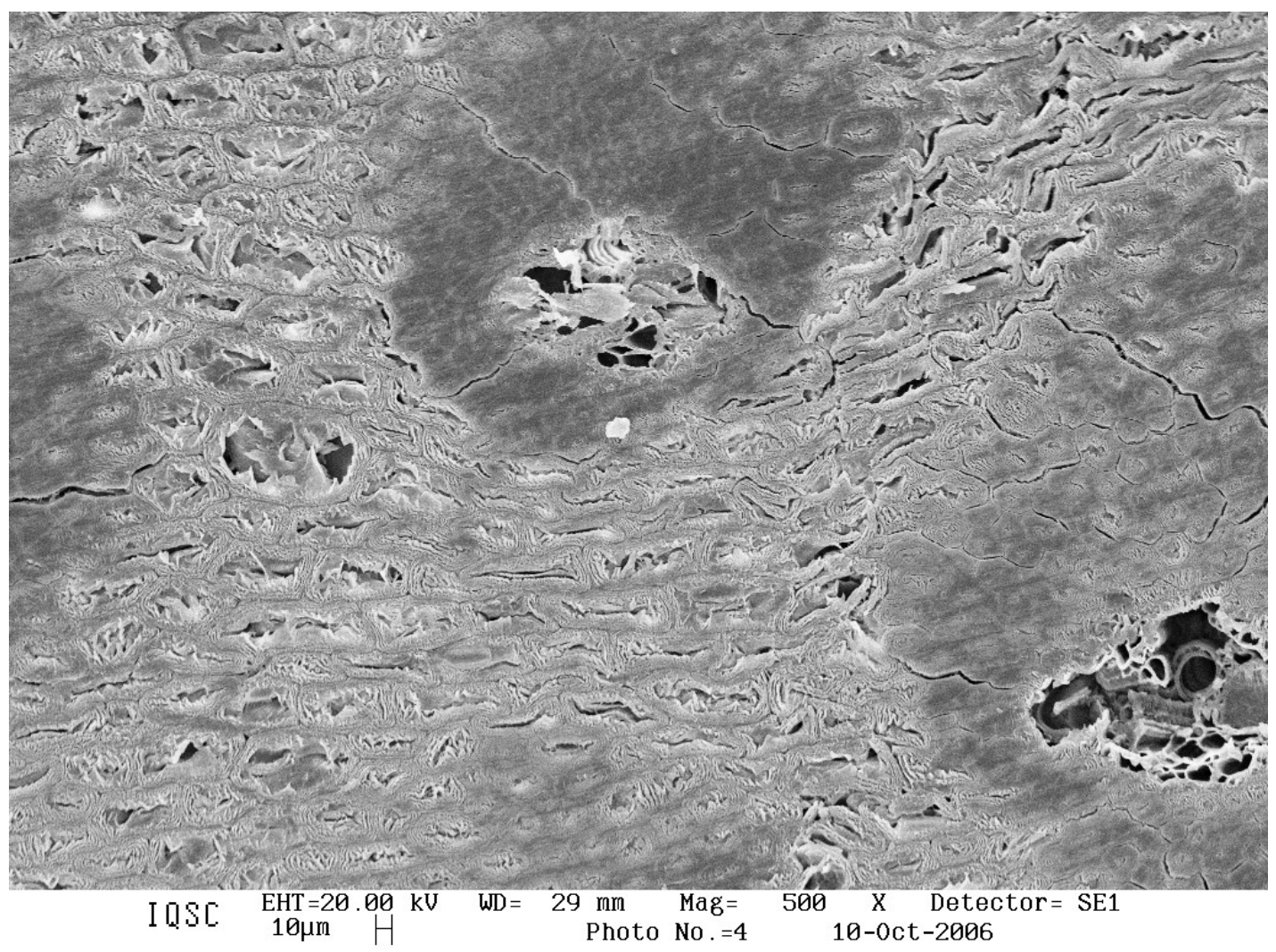

Figura 4.13. Micrografias da região transversal do painel de partículas longas de bagaço de cana-de-açúcar, com 10\% de resina à base de Cascomel MO $08 \mathrm{ME} \mathrm{e}$ prensado a quente em temperatura de $130^{\circ} \mathrm{C}$ em escala $500 \mathrm{x}$

Conforme verificado na Figura 4.13, notou-se um comportamento frontal com aspecto semelhante ao do painel produzido com resina à base de mamona, com presença de microporos localizados, pois o processo não é industrial. 


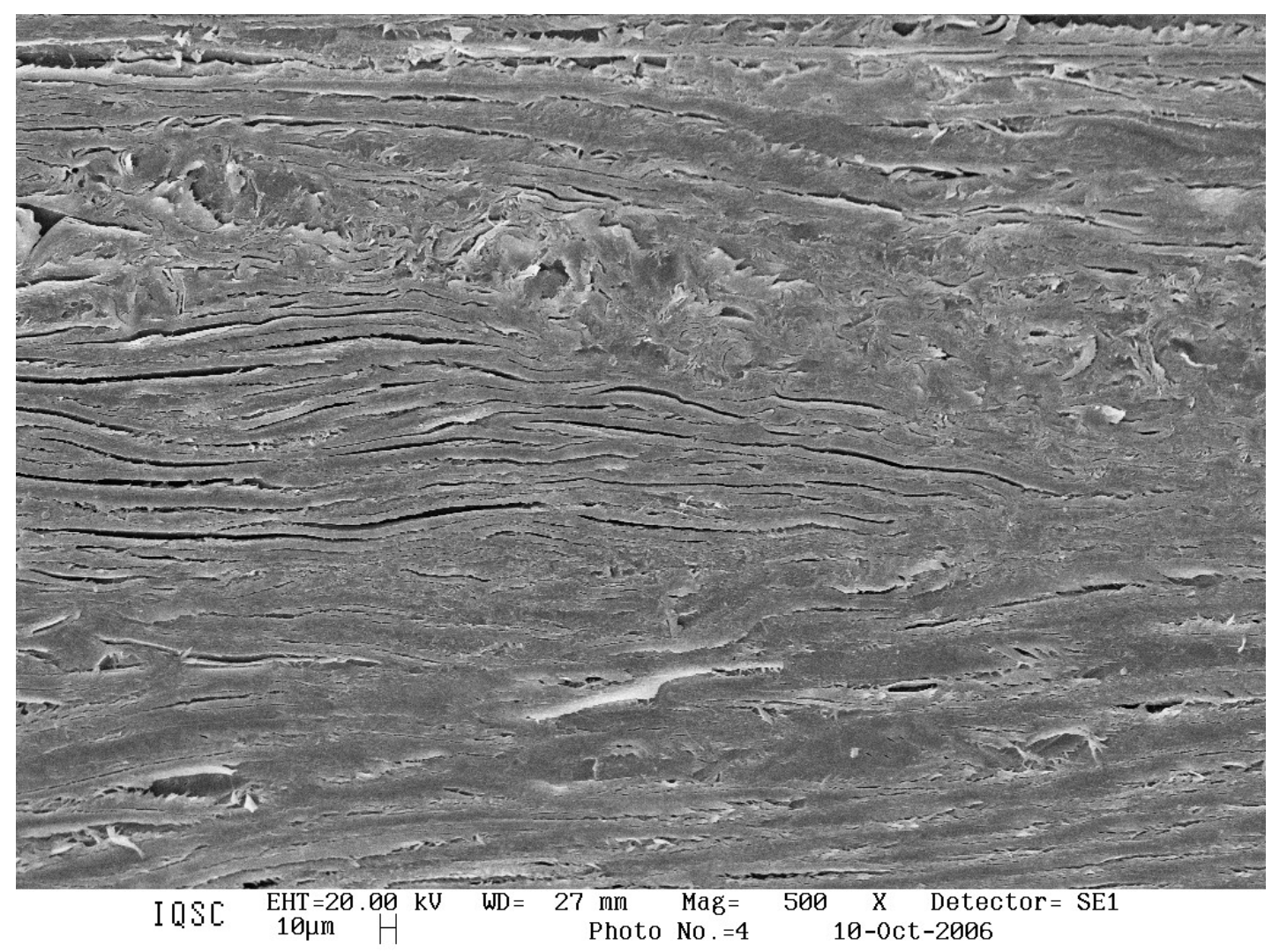

Figura 4.14. Micrografias da região de transição longitudinal do painel de partículas longas de bagaço de cana-de-açúcar, com $20 \%$ de resina à base de mamona e prensado a quente em temperatura de $90^{\circ} \mathrm{C}$ em escala $500 \mathrm{x}$

O painel de partículas longas e orientadas de bagaço da cana-de-açúcar, com $20 \%$ de resina à base de mamona, mostrou-se pouco influenciado pela resina, na adesão (Figura 4.14), com as partículas lignocelulósicas de bagaço de cana. Esperava-se uma microestrutura mais compacta. 


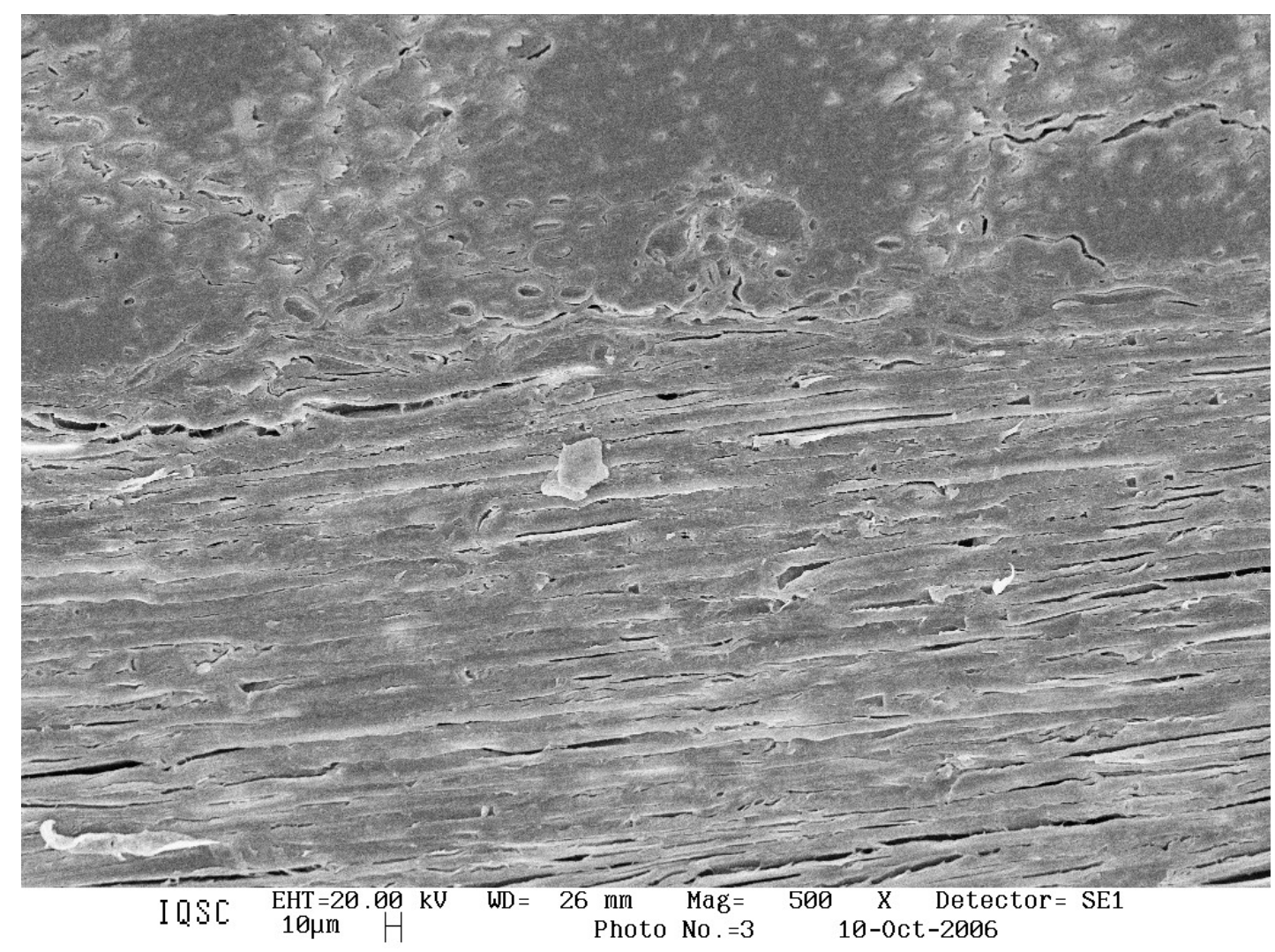

Figura 4.15. Micrografias da região de transição longitudinal/transversal do painel de partículas longas de bagaço de cana-de-açúcar, com $20 \%$ de resina à base de mamona e prensado a quente em temperatura de $90^{\circ} \mathrm{C}$ em escala $500 \mathrm{x}$

Na região de transição das camadas longitudinal e transversal, observou-se que, mesmo a $90^{\circ} \mathrm{C}$ de temperatura, houve uma melhora na compactação e impregnação da resina no resíduo de bagaço de cana (Figura 4.15), concluindo que, ao elevar esta temperatura, com esta quantidade de resina, obtem-se um resultado de uma chapa mais coesa. 


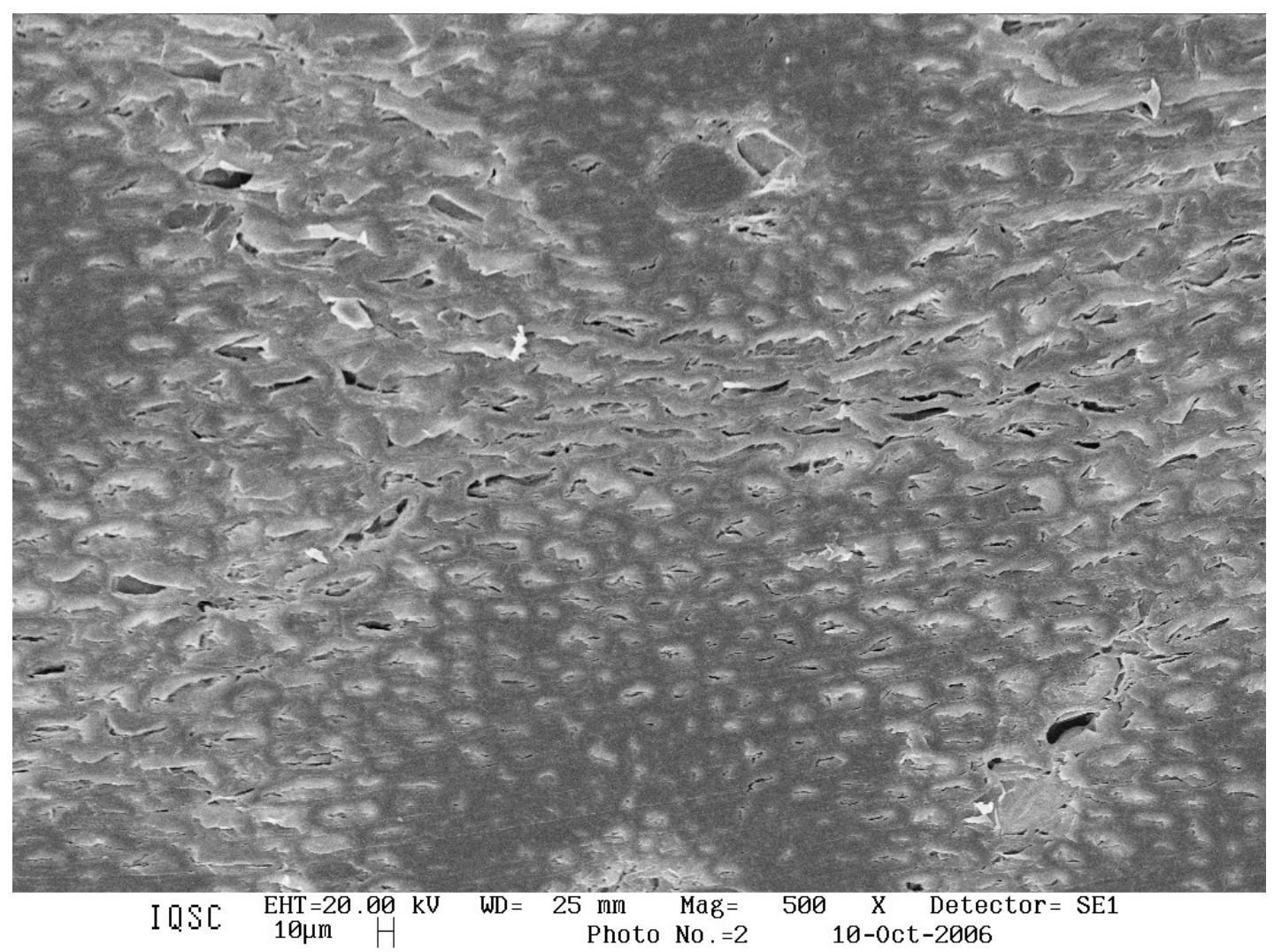

Figura 4.16. Micrografias da região de transversal do painel de partículas longas de bagaço de cana-de-açúcar, com $20 \%$ de resina à base de mamona e prensado a quente em temperatura de $90^{\circ} \mathrm{C}$ em escala $500 \mathrm{x}$

A microscopia de varredura frontal (Figura 4.16), mostrou o grau excelente de impregnação resina/resíduo, concluindo que, para uso de temperatura a $90^{\circ}$, este teor de resina pode satisfazer os resultados, com melhoria das propriedades ao elevar para $130^{\circ} \mathrm{C}$, com um menor tempo de prensagem do painel. 


\section{CONCLUSÕES}

Os resultados obtidos com o desenvolvimento do presente trabalho permitem que sejam registradas as seguintes conclusões:

- Ficou demonstrada a viabilidade de produção de painéis de partículas longas e orientadas de bagaço de cana, com desempenho similar ao do painel OSB derivado da madeira.

- O ensaio de degradação térmica demonstrou e excelente comportamento do bagaço de cana até temperatura próxima a $200^{\circ} \mathrm{C}$, superior às temperaturas usualmente empregadas no processo de produção de painéis particulados com resinas comerciais.

- A resina poliuretana à base de mamona e a resina Cascomel M 08 ME, são compatíveis com o bagaço de cana para a produção de painéis particulados, o que é confirmado pelos resultados obtidos para as propriedades físicas e mecânicas quando corpo-de-prova é prensado em temperatura de $130^{\circ} \mathrm{C}$. Tais propriedades atendem a requisitos da EN300/2002 para painéis OSB, nas diferentes faixas ali sugeridas para as aplicações do referido produto. 
- Fica evidente a influência da porcentagem de resina aos valores de adesão interna, o que sugere, para futuros trabalhos, a avaliação do comportamento de painéis produzidos com outras porcentagens de resina, de modo a se alcançar o menor custo do produto, com o menor consumo de resina.

- Conclui-se que as partículas longas e orientadas de bagaço de cana-deaçúcar são diretamente proporcionais ao processo da mistura e ao controle de peso nas camadas, com prioridade para as camadas internas.

- As variáveis, temperatura de prensagem, orientação das partículas longas, misturador e o teor de resina influenciam nas propriedades físicas e mecânicas dos painéis particulados produzidos. Como decorrência, é possível a determinação dos níveis mais convenientes das referidas variáveis para o atendimento dos requisitos de cada uma das faixas de aplicação preconizadas pelo documento normativo EN-300/2002, relativo ao OSB, e tomado como referencia neste trabalho, dada a inexistência de norma especifica para painéis particulados de bagaço de cana.

- Conclui-se também que o melhor desempenho é para o painel de bagaço de cana com $10 \%$ de resina à base de mamona a temperatura de $130^{\circ} \mathrm{C}$, em misturador. 


\section{RECOMENDAÇÕES PARA TRABALHOS FUTUROS}

Com base nas conclusões deste trabalho, podem ser apresentadas as seguintes recomendações para desenvolvimento de futuros trabalhos:

- É imprescindível o uso do orientador de partículas para a obtenção de painéis com propriedades elevadas.

- Determinar as proporções mais adequadas para as resinas, em relação ao peso do bagaço de cana, para o atendimento dos requisitos normativos para cada uso final dos painéis. Com isto, se alcançarão os patamares de custo mais competitivos para os painéis de partículas longas e orientadas de bagaço de cana.

- Determinar as temperaturas e as pressões de prensagem mais adequadas para a produção de painéis, com objetivos análogos aos mencionados no item anterior. 


\section{REFERENNCIAS}

ALBUQUERQUE, C. E. C.; MENDES, L.M. OSB: processo industrial e considerações. Revista da Madeira, Curitiba, n. 46, p. 56 - 66. 2000.

ATCHINSON, J.E.; LENGEL, D.E. Rapid growth in the use of bagasse as a raw material for re-constituted panel board. In: Particleboard Symposium, 29, Washington State University, Pullman, WA, 1985.. Proceedings.

ARAUJO, L. C. R. Caracterização química e mecânica de poliuretanas elastoméricas baseadas em materiais oleoquímicos. 1992. Dissertação (Mestrado em Química) - Instituto de Física e Química de São Carlos, Universidade de São Paulo, São Carlos, 1992.

BAYER, O . Polyurethanes. Modern Plastics, v.24, p. 149, 1947.

BORTOLETTO JÚNIOR, G.; GARCIA, J. N. . Propriedades de resistência e rigidez à flexão estática de painéis compensados e OSB. Revista Árvore, Viçosa - MG, v. 28, n. 4, p. 557-564, 2004.

CANADIDO, L.S.; SAITO, F.; SUZUKI, S. Influence of strand thickness and board density on the orthotropic properties of oriented stranboard. Journal of the Japan Wood, Tokyo, v. 36, n. 8, p. 632-636, 1990.

CARNEIRO, J. M. B.; MAGYAR, A. L.; GRANJA, S. I. B. Meio ambiente, empresário e governo: conflitos ou parceria? Revista de Administração de Empresas, São Paulo, v. 33, n. 2, p. 68-75, abril 1993.

CINTRA, F. N.; ANDRADE, P. Avaliação dos Impactos Ambientais do Setor Canavieiro Contemporâneo. Trabalho Apresentado no VII Encontro Nacional de Gestão Empresarial e Meio Ambiente - ENGEMA. São Paulo, 2003, cd-rom.

CLARO NETO, S. Caracterizações físico-químicas de um poliuretano derivado de óleo de mamona utilizado para implantes ósseos. São Carlos, 1997. 127p. Tese 
(Doutorado em Química) - Instituto de Química de São Carlos, Universidade de São Paulo.

CLOUTIER, A . Oriented strandboard (OSB): raw material, manufacturing process, properties and uses. In: INTERNATIONAL SEMINAR ON SOLID WOOD PRODUCTS OF HIGH TECHNOLOGY, 1., 1998, Belo Horizonte-MG. Proceedings ... Belo Horizonte, 1998.p. 173-185.

DIAS, F. M. Aplicação de resina poliuretana à base de mamona na fabricação de painéis de madeira compensada e aglomerada. São Carlos, 2005. 151p. Tese (Doutorado em Ciência e Engenharia de Materiais) - Escola de Engenharia de São Carlos/Instituto de Física de São Carlos/Instituto de Química de São Carlos - São Paulo.

EUROPEAN COMMITTEE FOR STANDARDIZATION. European Standard EN 300: Aglomerado de partículas de madeira longas e orientadas (OSB) Definições, classificação e especificações. Portugal, 2002.

EUROPEAN COMMITTEE FOR STANDARDIZATION. European Standard EN 717 - 1 e 2. Placas de derivados de madeira - Determinação de libertação de formaldeído - Parte 1: Determinação da emissão de formaldeído através do método de câmara e Parte 2: Determinação da emissão de formaldeído através do método de análise de gases. Portugal, 2002.

FRANKLIN ADHESIVES. Trinta principios da colagem de Madeira. Disponível em:<. http:www.franklinadhesives.com/> . Acesso em: 09 de Dezembro de 2005

GOMEZ, A.; GÁLVEZ, L.; DE LA OSA, O. Sugar cane bagasse. Utilization for production of composites. The state of the art in Cuba. INTERNATIONAL MACROMOLECULAR SYMPOSIUM ON LIGNOCELLULOSICS-PLASTICS COMPOSITES, São Paulo, 1996. Proceedings. São Carlos, USP/UNESP, 1997. p.281-324.

GEIMER, R. L. Dimensional stability of flakeboard as affected by board specific gravity and flake alignement. Forest Products Journal, Madison, v. 32, n. 8, p. 4452. 1982.

HAMID, S. H.; MAADHAH, A. G.; USMANI, A. M. Bagasse-based building materials. Polymer-Plastics Technology and Engineering, v.21, n.2, p.173, 1983.

HAN, G.; WU. Q. Comparative properties of comrind and wood strands for structural composite manufacturing. Forest Products Journal 54(12):283-294, 2004.

HOUWINK, R.; SALOMON, G. Adhesion and adhesives. 2 ed. New York: Elsevier Publishing Company, 1965.

IWAKIRI, S. Painéis de Madeira. Fundação de pesquisas Florestais - FUPEF Paraná, Universidade Federal do Paraná, nº1/98. 1. ed. 1998. 
JESUS, J. M. H. Estudo do adesivo poliuretano à base de mamona em madeira laminada colada(MLC). São Carlos, 2000, 106p. Tese (Doutorado em Ciência e Engenharia de Materiais) - Escola de Engenharia de São Carlos, Universidade de São Paulo.

JOAQUIM, A. P. Estudos das etapas de ativação no processo de benzilação da polpa de medula de bagaço de cana-de-açúcar. São Carlos, 1997. 78p. Dissertação (Mestrado em Química) - Instituto de Química de São Carlos, Universidade de São Paulo.

JORNALCANA. O aproveitamento total da cana. p. 19-21, fevereiro de 1999.

KELLY, M.W. A critical literature review of relationships between processing parameters and physical properties of particleboards. U.S. For. Prod. Lab. General Technical Report FPL-10, Madison, 1977, 66p.

KIRCHHOFF, V.W.J.H. As queimadas da cana. São José dos Campos.:Transtec Editorial, 1991.

MACHADO, G. O. Preparação e caracterização de CMC e CMC graftizado. São Carlos, 2000. 101p. Disssertação de Mestrado - Instituto de Química de São Carlos, Universidade de São Paulo.

MAGALHÃES, P. S. G. ; BRAUNBECK, O. A. . Colheita de cana-de-açúcar verde: energia renovável para uma agricultura sustentável. Agrobrasil, v. 1, p. 1-1, 1998.

MALLIK, A.V.; GIMINGHAM, C.H.; RAHMAN, A.A. Ecological effects of heather burning. I. Water infiltration, moisture retention and porosity of surface soil. Journal of Ecology, Oxford, v.72, n.3, p.767-776, 1984.

MALONEY, T.M. The development in the United States and Canada of Waferboard, oriented strand board, and medium density fibreboard. Holz Als Roh Und Werkstoff, Berlin, v. 42, n.10, p. 361-365. 1984.

MARRA, A.A. Technology of wood bonding: principles in practice. New York: Van Nostrand Reinhold. 1992. 453p.

MANTILLA CARRASCO, E. V. Ligações estruturais de madeira por adesivos. 1984. 2v. Dissertação ( Mestrado em Engenharia de Estruturas) - Escola de Engenharia de São Carlos, Universidade de São Paulo. São Carlos,1984.

MATTOS, K. M. C.; MATTOS, A. Valorização econômica do meio ambiente: uma abordagem teórica e pratica. São Paulo:Rima Editora, Fapesp, 2004.148p.

MENDES, L. M. Pinus spp. Na produção de painéis de partículas orientadas (OSB). Curitiba, 2001. 163p Tese (Doutorado em Ciências Florestais) Universidade Federal do Paraná. 
OTTMAN, J. A. Marketing verde: desafios e oportunidades para a nova era do marketing. São Paulo: Makron Books, 1994.

RIPOLI, T. C.; MIALHE, L. G.; BRITO, J. O. Queima de canavial: o desperdício não mais admissível. Revista Álcool e Açúcar, Piracicaba, v. 10, n. 54, p. 18-23, julho/agosto 1990.

RIPOLI, T.C.;VILANOVA, N. A. Colheita mecanizada da cana-de-açúcar:novos desafios. Revista STAB, Piracicaba, v. 11, n. 1, p. 28-31, set./out. 1992.

ROCHA, G. J. M.; GONÇALVES, A.R. Bagaço-de-cana: a principal matéria prima da pesquisa aplicada no grupo de conversão de biomassa vegetal da Faenquil. Revista Alcoolbrás., v.7, n.96, p. 98-99. 2005.

ROMEIRO, A. R. Desenvolvimento econômico e a questão ambiental: algumas considerações. Revista Análise Econômica, UFRGS, v. 9, n. 16, p. 141-152, set. 1991.

SANTANA, M.A.E.; TEIXEIRA, D.E. Uso do bagaço de cana-de-açúcar na confecção de chapas de aglomerados. In: CONGRESSO FLORESTAL BRASILEIRO, 7; CONGRESSO FLORESTAL PANAMERICANO, 1. Curitiba, 1993. Anais. São Paulo: SBS/SBEF, 1993. p. 667-672.

SHAPIRO, S. S.; FRANCIA, R. S. An Approximate Analysis of Variance Test for Normality. Journal of the American Statistical Association, v. 67, p.215, 1972.

SOBRAL FILHO, M. Influence of wood furnish type on properties of oriented strand panels. Forest Products Journal, Madison, v.31, n. 9, p. 43-52. 1981.

STRUCTURAL BOARD ASSOCIATION . Boletins Técnicos e catálogos. Canadá.: SBA,2000.

SUZUKI, S.; TAKEDA, K. Production and properties of Japanese oriented strand board I: effect of strand length and orientation on strength properties of sugi oriented strand board. . Japan Wood Science, Tokyo, v. 46, p. 289-295, 2000.

TOMASELLI,I.; LOPES,F.; \& TUOTO,M. Qual o futuro para chapas “OSB” no Brasil. STCP Informativo, Curitiba, n.2, 1998. 30p.

VICK, C. B. Adhesive bonding of wood materials. In: Wood handbook - Wood as an engineering material/ Department of Agriculture. Forest Service. Forest Products Laboratory. Washington: Usda, 1999. Cap. 9, p.463.

WATAI, L. T. Painéis estruturais -tendências e desenvolvimento no Brasil In: SEMADER,4, 1996, Curitiba. Anais. Curitiba, p. 71-74, 1996.

WURTZ, A.; LIEBIGS, J. Uber die Verbindungen der Cyansaure mit Aethylloxud, Methyloxud, Amyloxud und die daraus entstehendon Producte: Acetyl- und 
Metacetytharnstoff, Methylamim, Aethylamim, Valeramin. Annalen. Chemic., v. 71, p. 326, 1849.

ZHANG, M. et al. Manufacture and properties of high-performance oriented strand board composite using thin strands. Japan Wood Science, Tokyo,n.44, p.191-197. 1998.

ZHOW, D. A study of oriented structural board made from hybrid poplar: physical and mechanical properties of OSB. Holz Als Roh Und Werkstoff, Berlin, v. 48, n. 7-8, p. 293-296, 1990. 
8. ANEXO A - TABELAS DA EN 300/2002 
Tabela 8.1 - Painéis para usos gerais, incluindo mobiliário, interiores, utilizados em ambiente seco.

\begin{tabular}{|c|c|c|c|c|c|}
\hline Placa tipo OSB/ 1 & \multirow{2}{*}{ Norma e Unidade } & \multicolumn{4}{|c|}{ Requisitos } \\
\cline { 4 - 6 } \multicolumn{2}{|c|}{ Propriedade } & \multicolumn{2}{|c|}{ Espessura do painel (mm). } \\
\cline { 4 - 6 } & & $\mathbf{6 ~ a ~ 1 0}$ & $>\mathbf{1 0}$ e < 18 & $\mathbf{1 8}$ a 25 \\
\hline MOR Direção longitudinal & EN 310 & MPa & 20 & 18 & 16 \\
\hline MOR Direção transversal & EN 310 & MPa & 10 & 9 & 8 \\
\hline MOE Direção longitudinal & EN 310 & MPa & 2500 & 2500 & 2500 \\
\hline MOE Direção transversal & EN 310 & MPa & 1200 & 1200 & 1200 \\
\hline Adesão interna & EN 319 & MPa & 0,30 & 0,28 & 0,26 \\
\hline $\begin{array}{c}\text { Inchamento em espessura } \\
\text { (24h) }\end{array}$ & EN 317 & $\%$ & 25 & 25 & 25 \\
\hline
\end{tabular}

Fonte: EN 300/2002.

Tabela 8.2 - Painéis para fins estruturais utilizados em ambiente seco, requisitos para as propriedades mecânicas e de inchamento.

\begin{tabular}{|c|c|c|c|c|c|}
\hline Placa tipo OSB/ 2 & \multirow{2}{*}{ Propriedade } & \multicolumn{3}{|c|}{ Norma e Unidade } & \multicolumn{3}{|c|}{ Requisitos } \\
\cline { 5 - 7 } & & & 6spessura do painel (mm). \\
\hline MOR Direção longitudinal & EN 310 & $\mathrm{MPa}$ & 22 & 20 & 18 \\
\hline MOR Direção transversal & EN 310 & $\mathrm{MPa}$ & 11 & 10 & 9 \\
\hline MOE Direção longitudinal & EN 310 & $\mathrm{MPa}$ & 3500 & 3500 & 3500 \\
\hline MOE Direção transversal & EN 310 & $\mathrm{MPa}$ & 1400 & 1400 & 1400 \\
\hline Adesão interna & EN 319 & MPa & 0,34 & 0,32 & 0,30 \\
\hline $\begin{array}{c}\text { Inchamento em espessura } \\
\text { (24h) }\end{array}$ & EN 317 & $\%$ & 20 & 20 & 20 \\
\hline
\end{tabular}

Fonte: EN 300/2002. 
Tabela 8.3 - Painéis para fins estruturais utilizados em ambiente úmido - Requisitos para as propriedades mecânicas e de inchamento.

\begin{tabular}{|c|c|c|c|c|c|}
\hline \multirow{3}{*}{$\begin{array}{c}\text { Placa tipo OSB/ } 3 \\
\text { Propriedade }\end{array}$} & \multirow{3}{*}{\multicolumn{2}{|c|}{ Norma e Unidade }} & \multirow{2}{*}{\multicolumn{3}{|c|}{$\begin{array}{c}\text { Requisitos } \\
\text { Espessura do painel (mm). }\end{array}$}} \\
\hline & & & & & \\
\hline & & & 6 a 10 & $>10$ e $<18$ & 18 a 25 \\
\hline MOR Direção longitudinal & EN 310 & $\mathrm{MPa}$ & 22 & 20 & 18 \\
\hline MOR Direção transversal & EN 310 & MPa & 11 & 10 & 09 \\
\hline MOE Direção longitudinal & EN 310 & $\mathrm{MPa}$ & 3500 & 3500 & 3500 \\
\hline MOE Direção transversal & EN 310 & MPa & 1400 & 1400 & 1400 \\
\hline Adesão interna & EN 319 & MPa & 0,34 & 0,32 & 0,30 \\
\hline $\begin{array}{c}\text { Inchamento em espessura } \\
(24 \mathrm{~h})\end{array}$ & EN 317 & $\%$ & 15 & 15 & 15 \\
\hline
\end{tabular}

Fonte: EN 300/2002.

Tabela 8.4 - Painéis para fins estruturais especiais utilizados em ambiente úmido Requisito para as propriedades mecânicas e de inchamento.

\begin{tabular}{|c|c|c|c|c|c|}
\hline Placa tipo OSB/4 & \multirow{2}{*}{ Norma e Unidade } & \multicolumn{4}{|c|}{ Requisitos } \\
\cline { 4 - 6 } Propriedade & \multicolumn{2}{|c|}{} & \multicolumn{3}{|c|}{ Espessura do painel (mm). } \\
\cline { 4 - 6 } & & $\mathbf{6 ~ a ~ 1 0}$ & $>\mathbf{1 0}$ e $<\mathbf{1 8}$ & $\mathbf{1 8}$ a 25 \\
\hline MOR Direção longitudinal & EN 310 & MPa & 30 & 28 & 26 \\
\hline MOR Direção transversal & EN 310 & MPa & 16 & 15 & 14 \\
\hline MOE Direção longitudinal & EN 310 & MPa & 4800 & 4800 & 4800 \\
\hline MOE Direção transversal & EN 310 & MPa & 1900 & 1900 & 1900 \\
\hline Adesão interna & EN 319 & MPa & 0,50 & 0,45 & 0,40 \\
\hline $\begin{array}{c}\text { Inchamento em espessura } \\
\text { (24h) }\end{array}$ & EN 317 & $\%$ & 12 & 12 & 12 \\
\hline
\end{tabular}

Fonte: EN 300/2002.

Observação: Se o comprador notificar que os painéis são destinados a uma utilização específica em pavimento, parede ou telhado, a Norma de desempenho correspondente também tem de ser consultada. Este fato pode implicar a observância de requisitos adicionais. 
9 ANEXO B - TESTE DE NORMALIDADE 


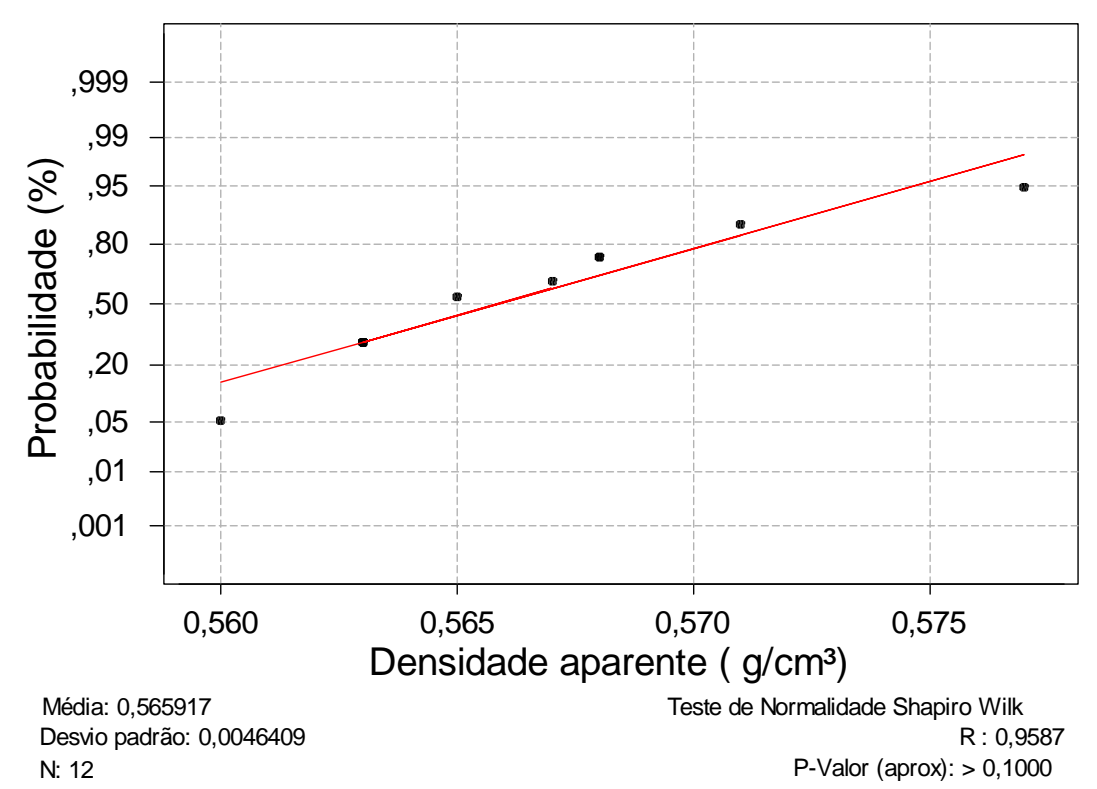

Figura 9.01. Teste de Normalidade para densidade aparente do compósito orientado de bagaço de cana-de-açúcar, com 10\% de resina poliuretana

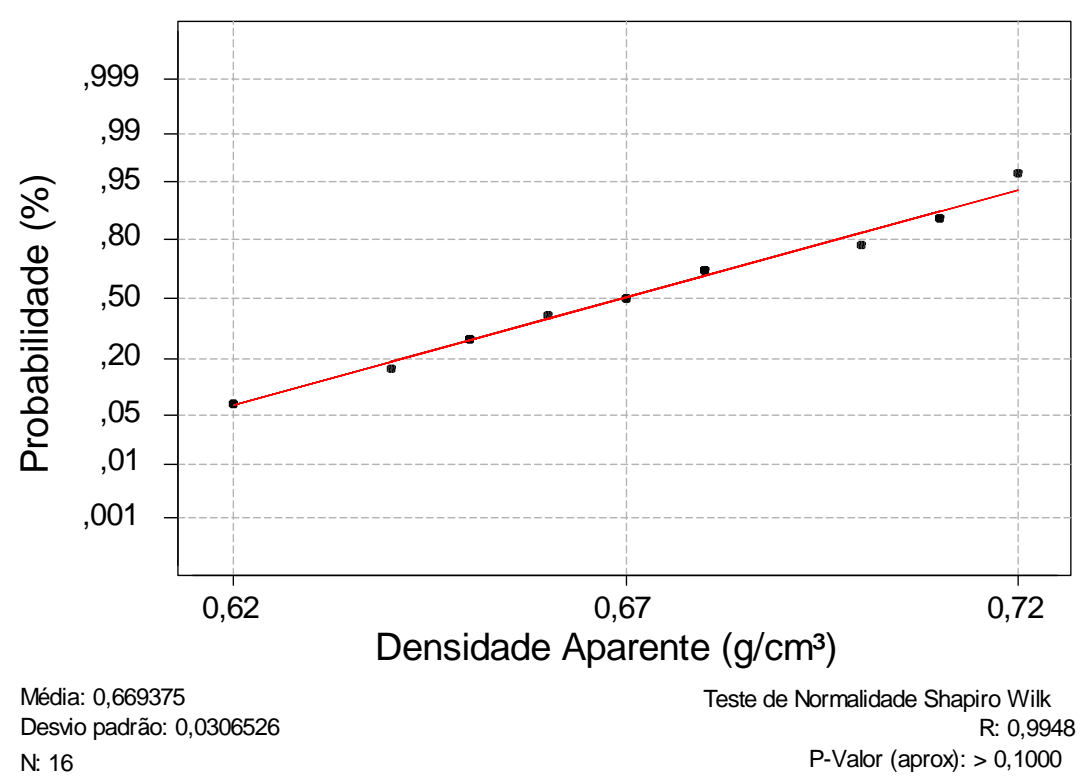

Figura 9.02. Teste de Normalidade para densidade aparente do compósito orientado de bagaço de cana-de-açúcar, com $10 \%$ de resina poliuretana, em misturador, a $90^{\circ} \mathrm{C}$ 


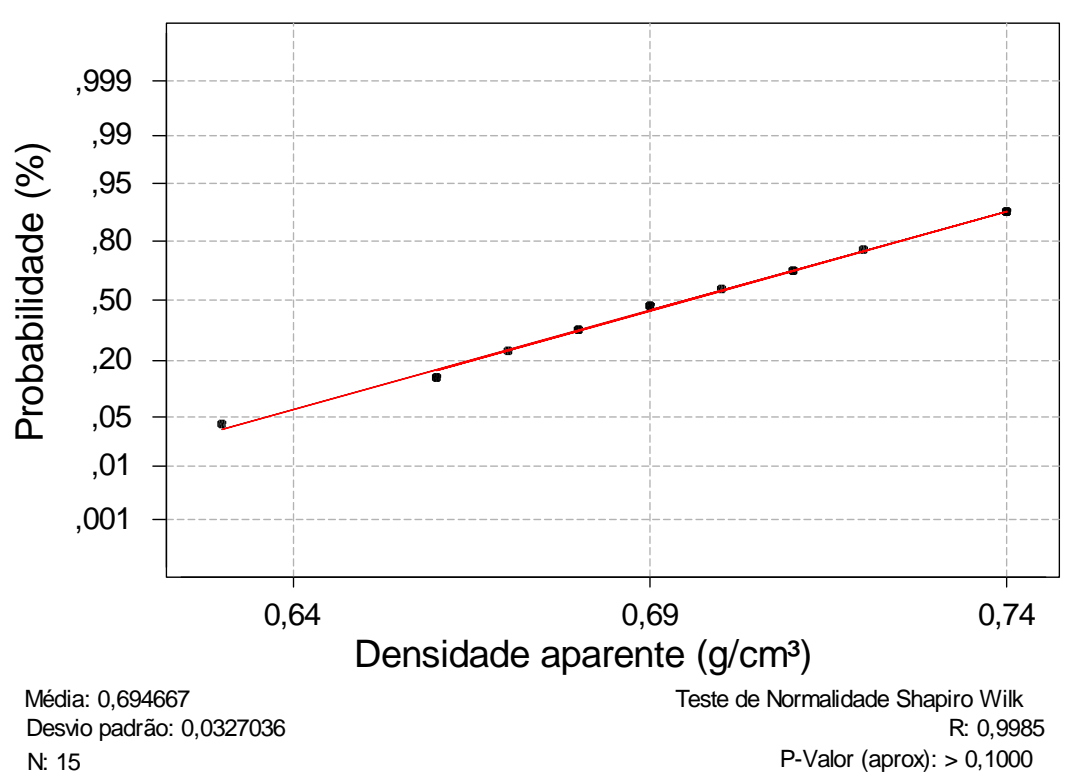

Figura 9.03. Teste de Normalidade para densidade aparente do compósito orientado de bagaço de cana-de-açúcar, com 10\% de resina poliuretana, em misturador, a $130^{\circ} \mathrm{C}$

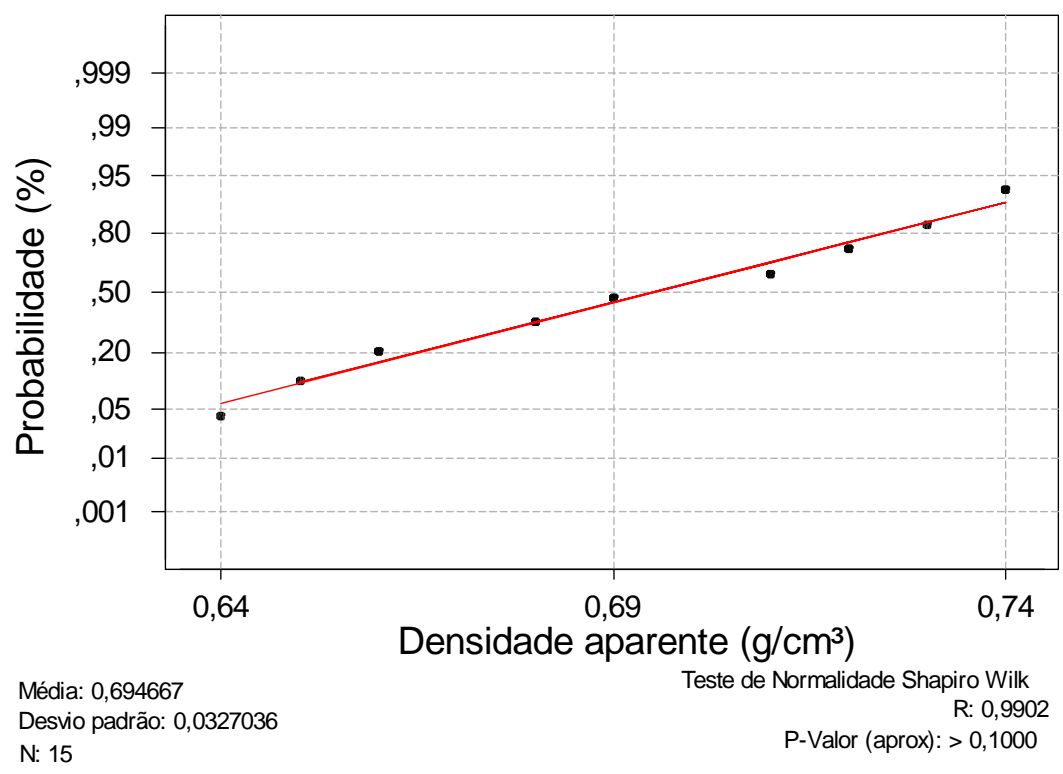

Figura 9.04. Teste de Normalidade para densidade aparente do compósito orientado de bagaço de cana-de-açúcar, com 10\% de resina Cascomel M 08 ME, em misturador, a $130^{\circ} \mathrm{C}$ 


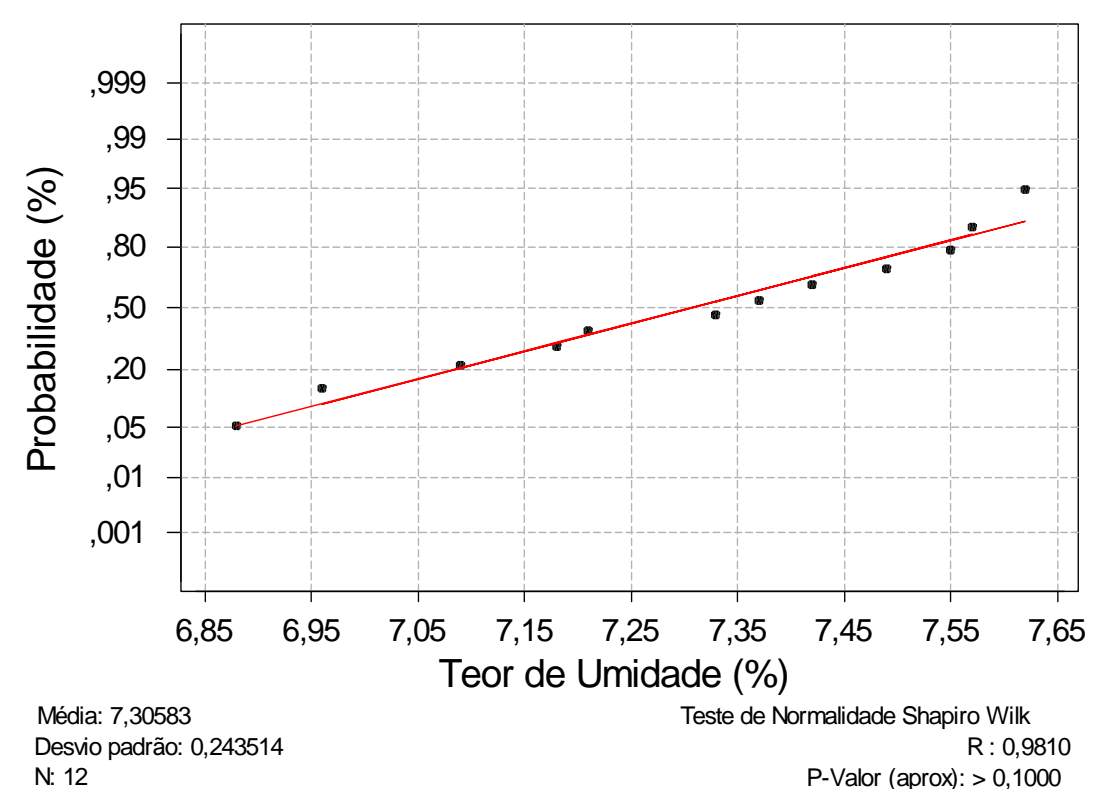

Figura 9.05. Teste de Normalidade para o teor de umidade do compósito orientado de bagaço de cana-de-açúcar, com $10 \%$ de resina poliuretana a $90^{\circ} \mathrm{C}$

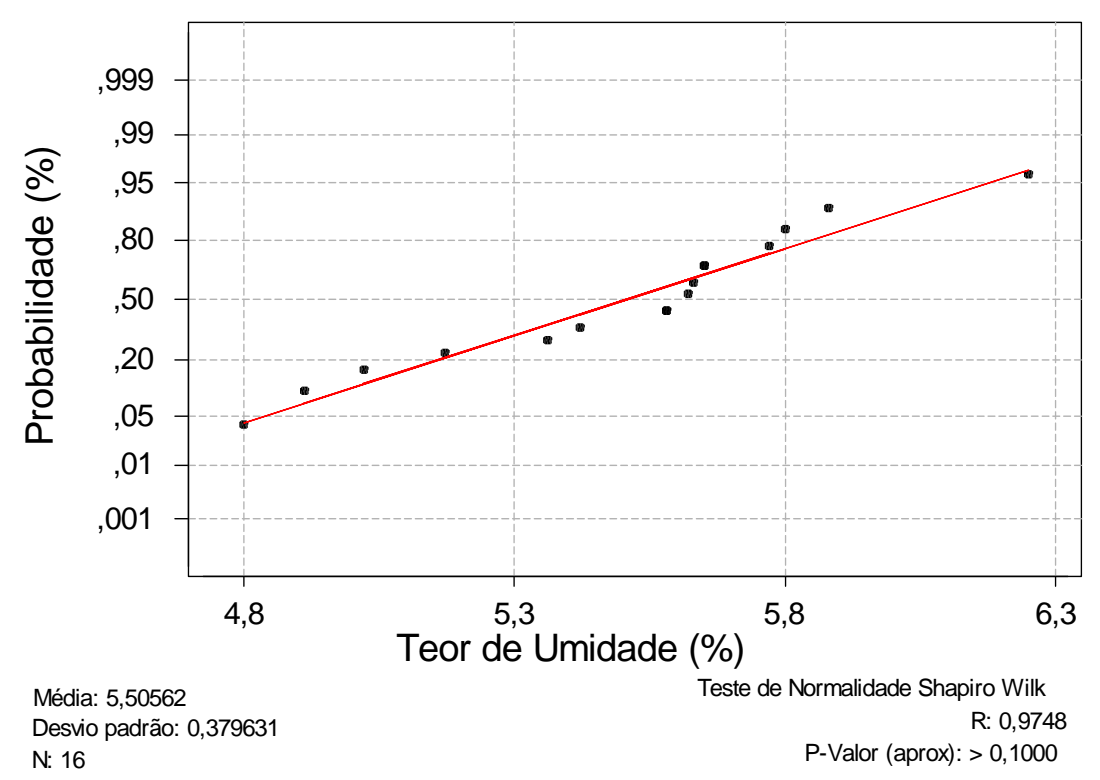

Figura 9.06. Teste de Normalidade para o teor de umidade do compósito orientado de bagaço de cana-de-açúcar, com $10 \%$ de resina poliuretana, em misturador a $90^{\circ} \mathrm{C}$ 


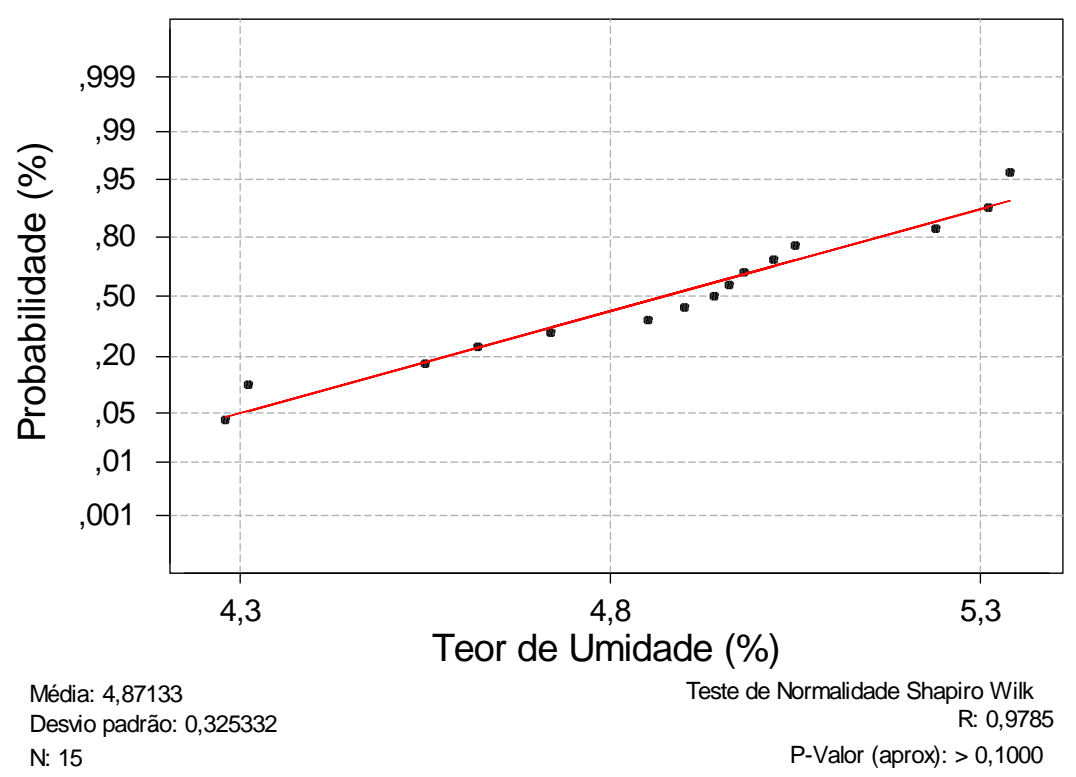

Figura 9.07. Teste de Normalidade para o teor de umidade do compósito orientado de bagaço de cana-de-açúcar, com $10 \%$ de resina poliuretana, em misturador a $130^{\circ} \mathrm{C}$

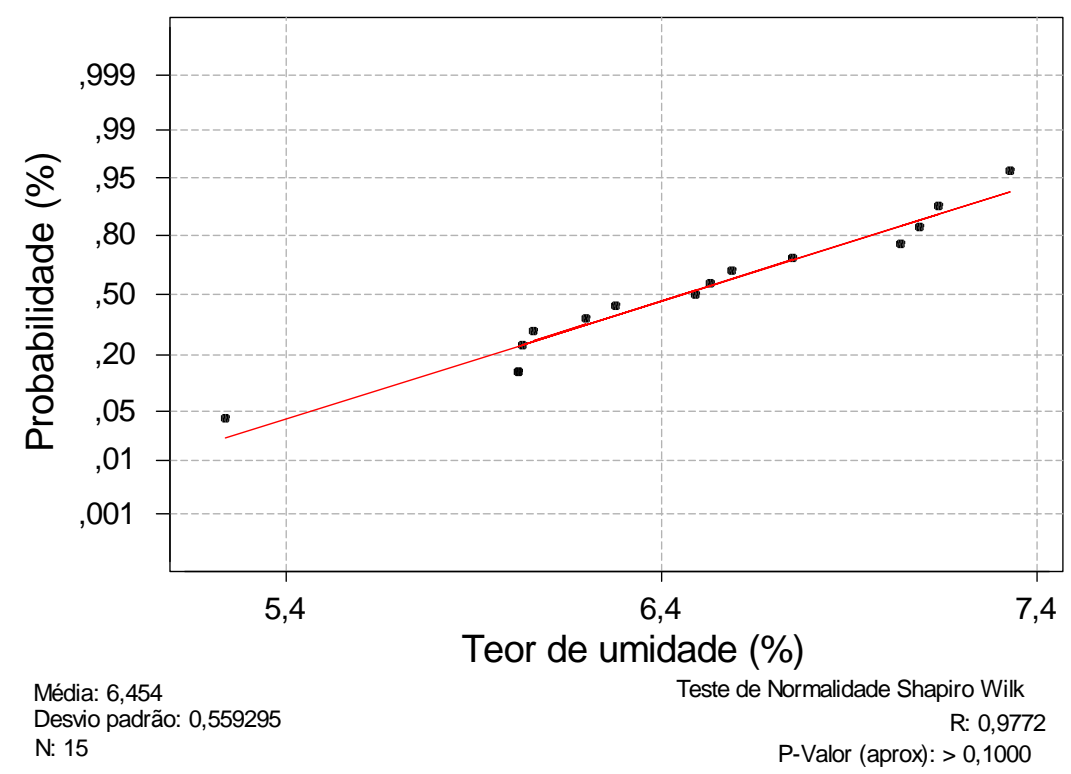

Figura 9.08. Teste de Normalidade para o teor de umidade do compósito orientado de bagaço de cana-de-açúcar, com 10\% de resina Cascomel M 08 ME, em misturador a $130^{\circ} \mathrm{C}$ 


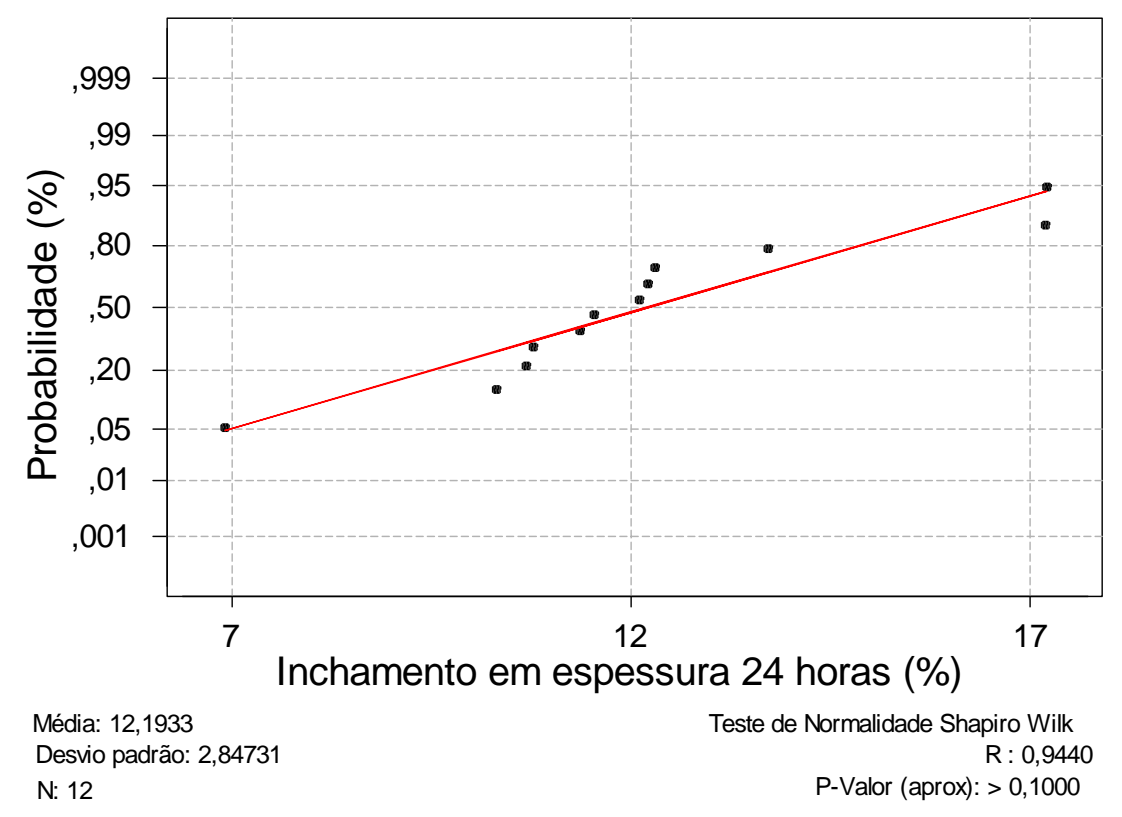

Figura 9.09. Teste de Normalidade para Inchamento em espessura 24 horas do compósito orientado de bagaço de cana-de-açúcar, com $10 \%$ de resina a $90^{\circ} \mathrm{C}$

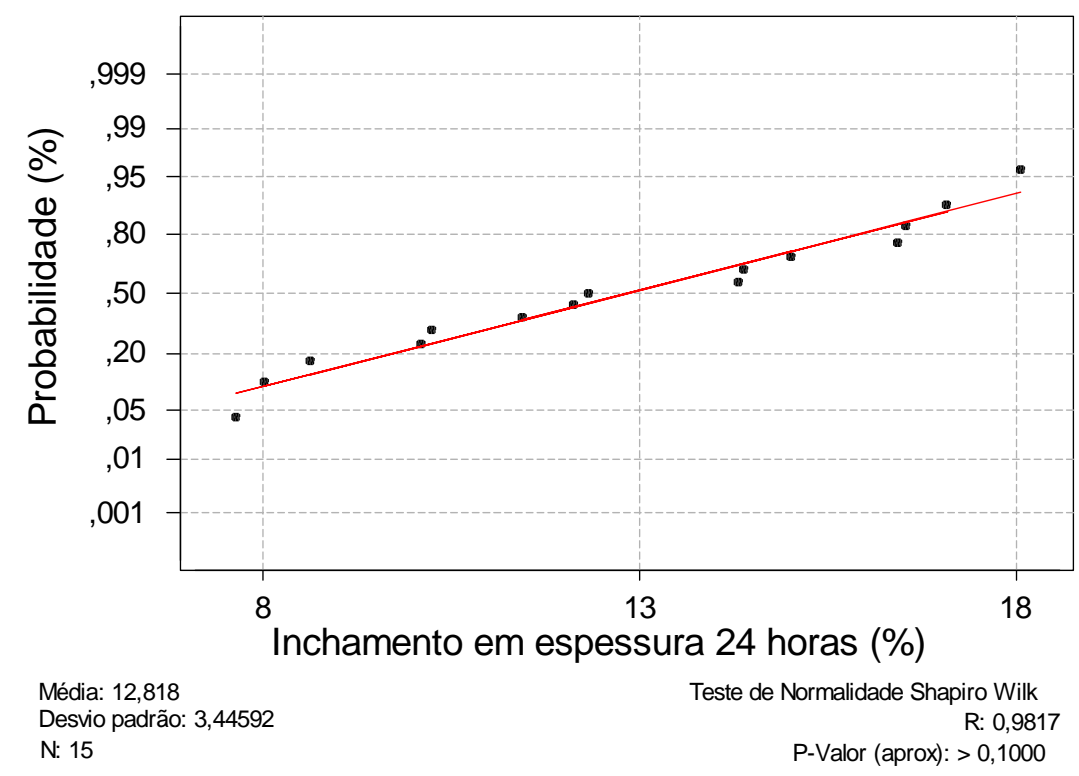

Figura 9.10. Teste de Normalidade para Inchamento em espessura 24 horas do compósito orientado de bagaço de cana-de-açúcar, com $10 \%$ de resina à base de mamona a $90^{\circ} \mathrm{C}$, em misturador 


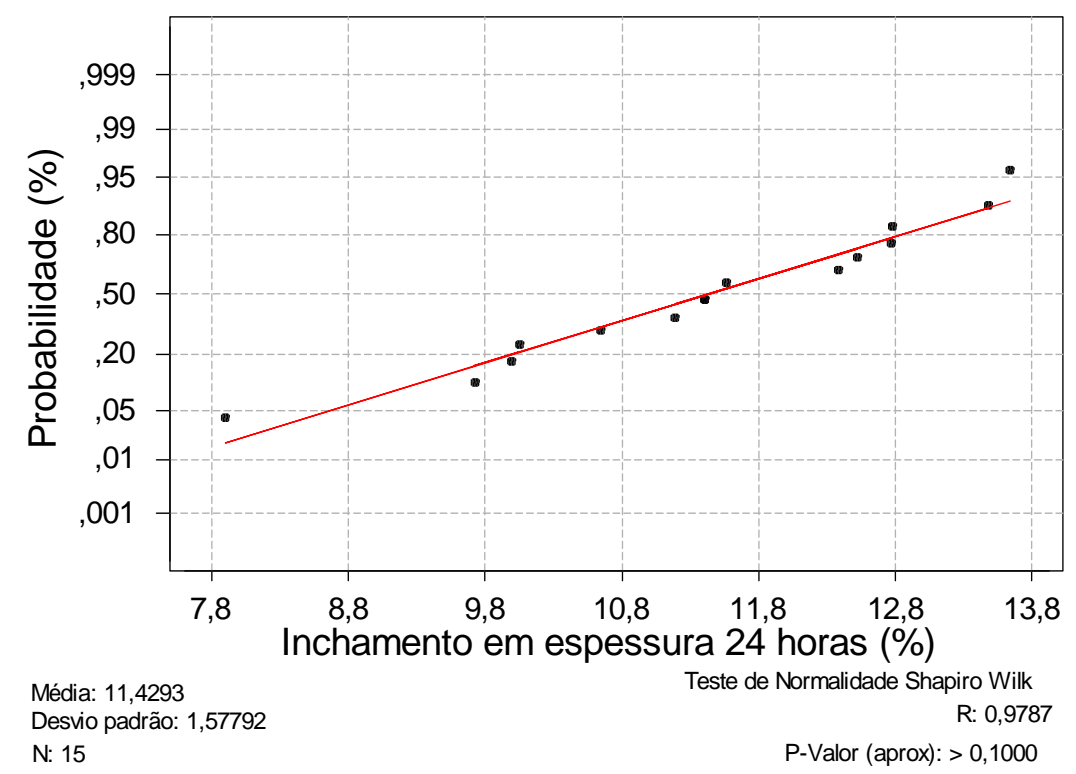

Figura 9.11. Teste de Normalidade para Inchamento em espessura 24 horas do compósito orientado de bagaço de cana-de-açúcar, com 10\% de resina à base de mamona a $130^{\circ} \mathrm{C}$, em misturador

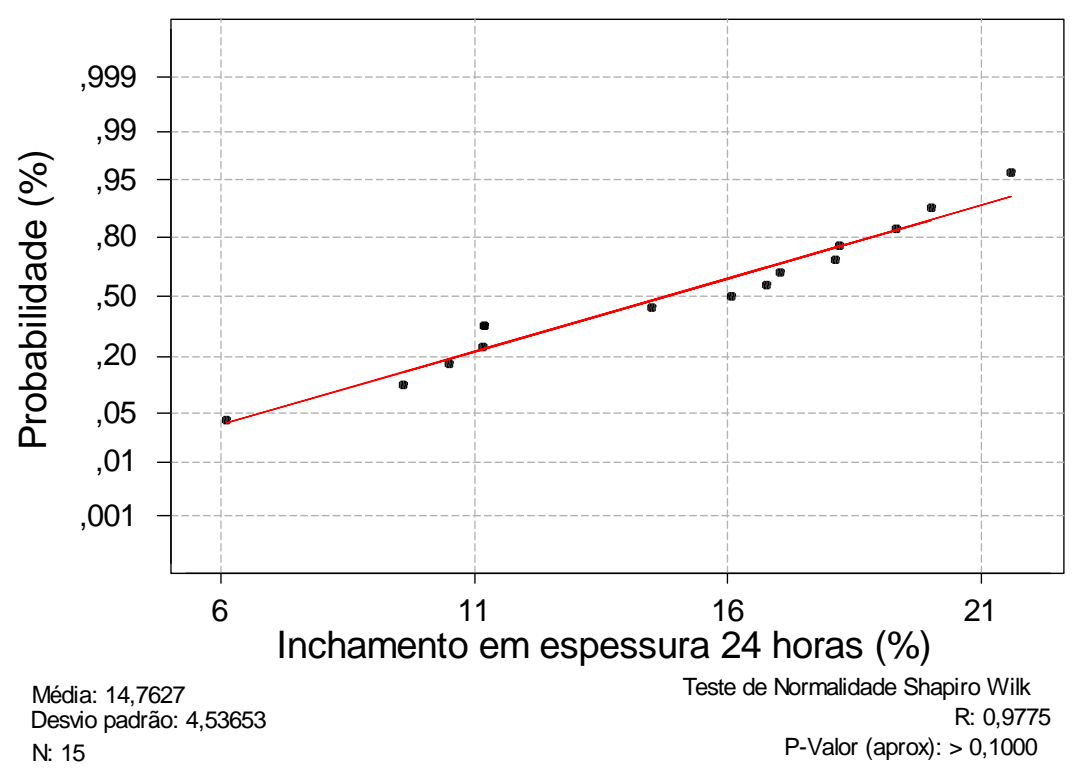

Figura 9.12. Teste de Normalidade para Inchamento em espessura 24 horas do compósito orientado de bagaço de cana-de-açúcar, com $10 \%$ de resina à base de Cascomel M $08 \mathrm{ME}$ a $130^{\circ} \mathrm{C}$, em misturador 


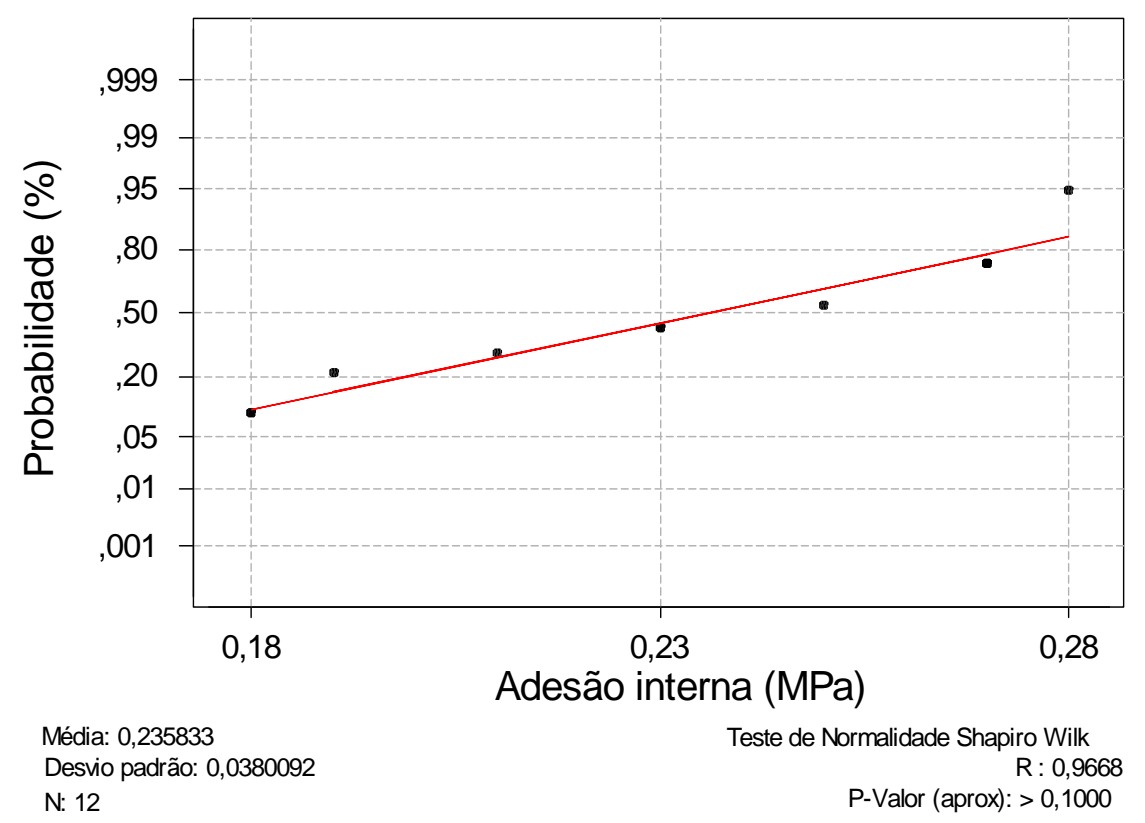

Figura 9.13. Teste de Normalidade para Adesão interna do compósito orientado de bagaço de cana-de-açúcar, com $10 \%$ de resina

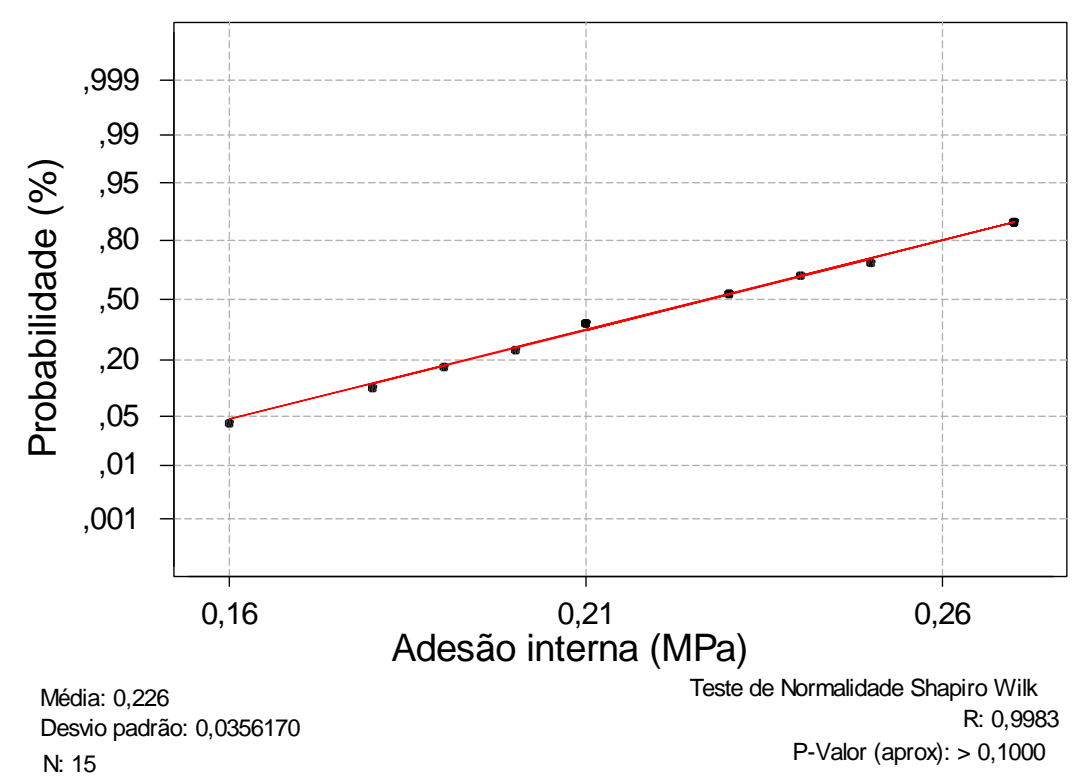

Figura 9.14. Teste de Normalidade para Adesão interna do compósito orientado de bagaço de cana-de-açúcar, com $10 \%$ de resina a $90^{\circ} \mathrm{C}$, em misturador 


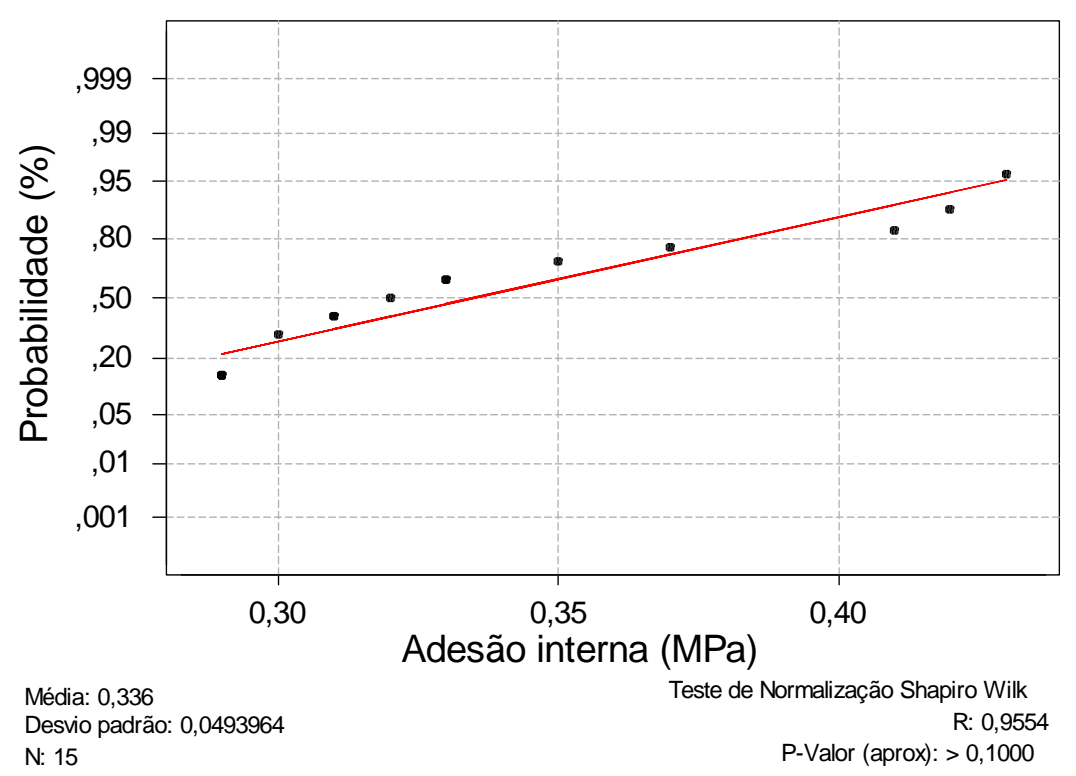

Figura 9.15. Teste de Normalidade para Adesão interna do compósito orientado de bagaço de cana-de-açúcar, com $10 \%$ de resina à base de mamona a $130^{\circ} \mathrm{C}$, em misturador

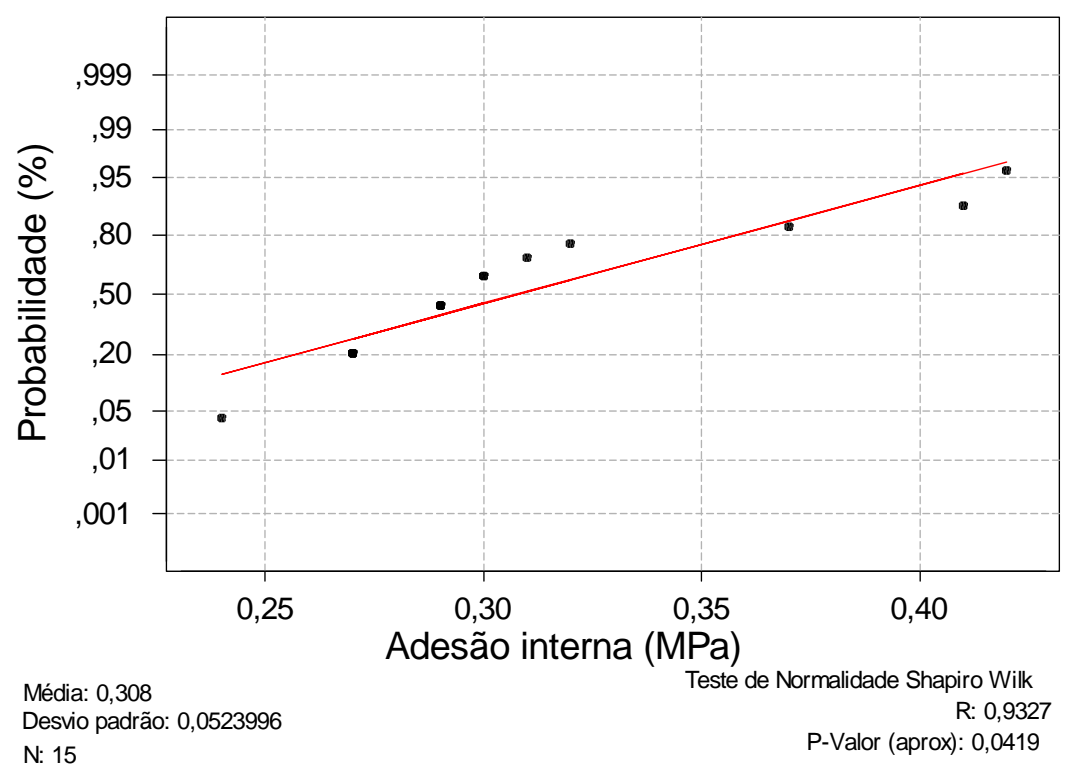

Figura 9.16. Teste de Normalidade para Adesão interna do compósito orientado de bagaço de cana-de-açúcar, com 10\% de resina à base de Cascomel M $08 \mathrm{ME}$ a $130^{\circ} \mathrm{C}$, em misturador 


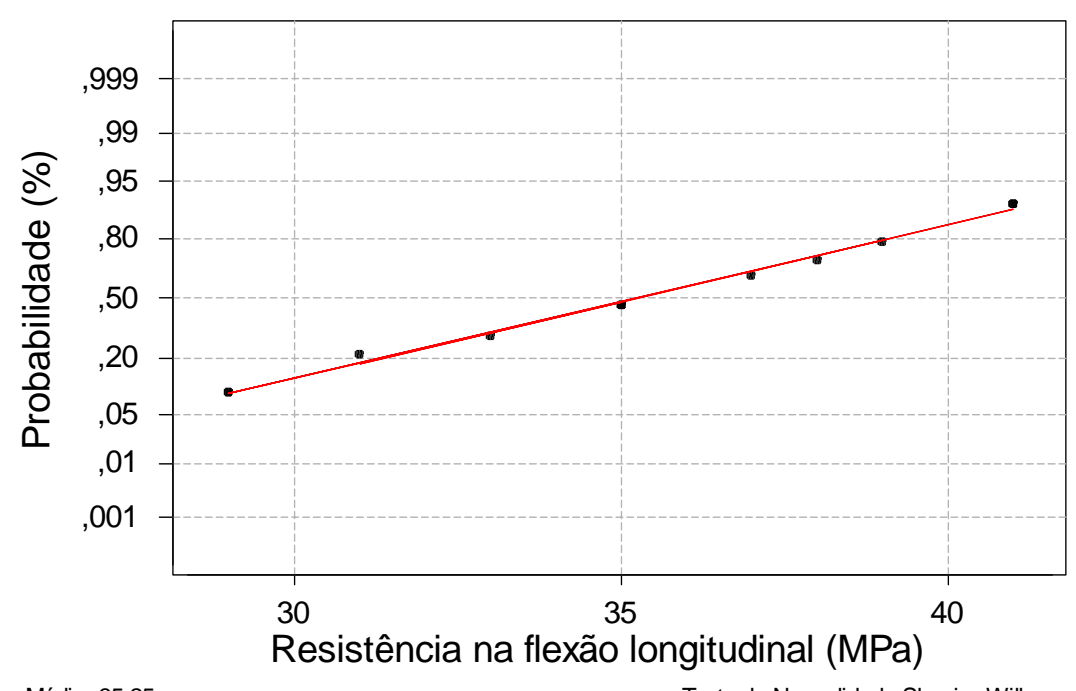

Média: 35,25

Desvio padrão: 4,18058

N: 12

Figura 9.17. Teste de Normalidade para a resistência na flexão longitudinal do compósito orientado de bagaço de cana-de-açúcar, com 10\% de resina poliuretana

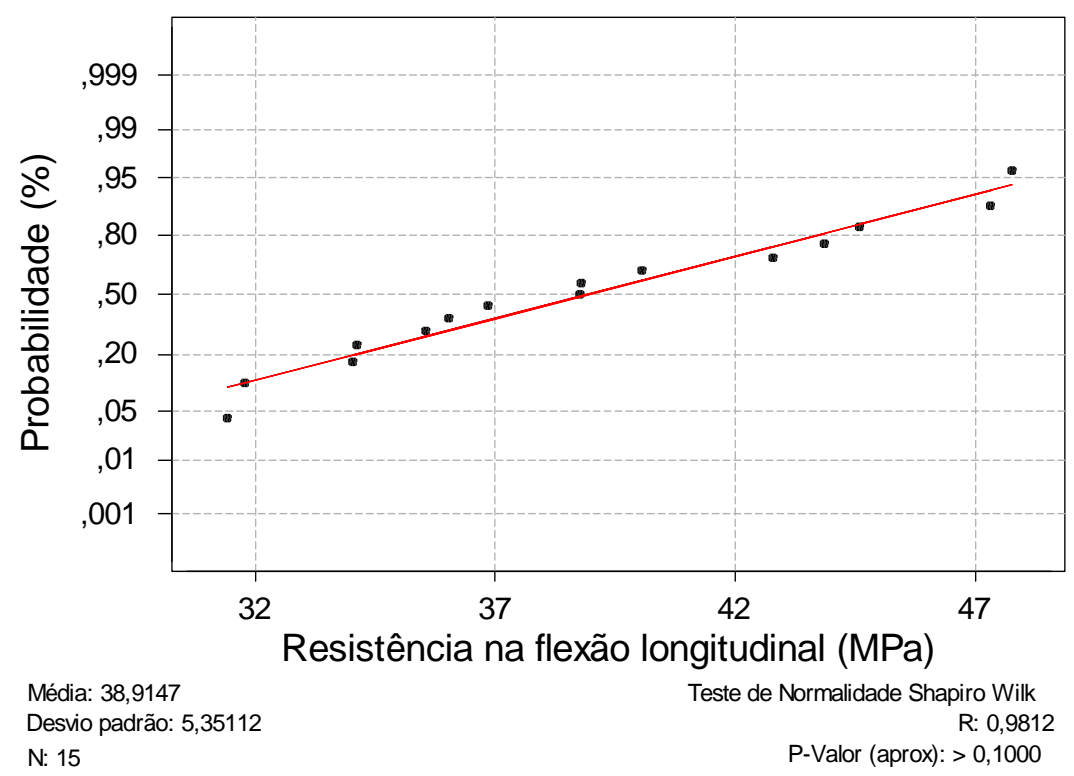

Figura 9.18. Teste de Normalidade para a resistência na flexão longitudinal do compósito orientado de bagaço de cana-de-açúcar, com $10 \%$ de resina poliuretana à base de mamona, em misturador a $90^{\circ} \mathrm{C}$ 


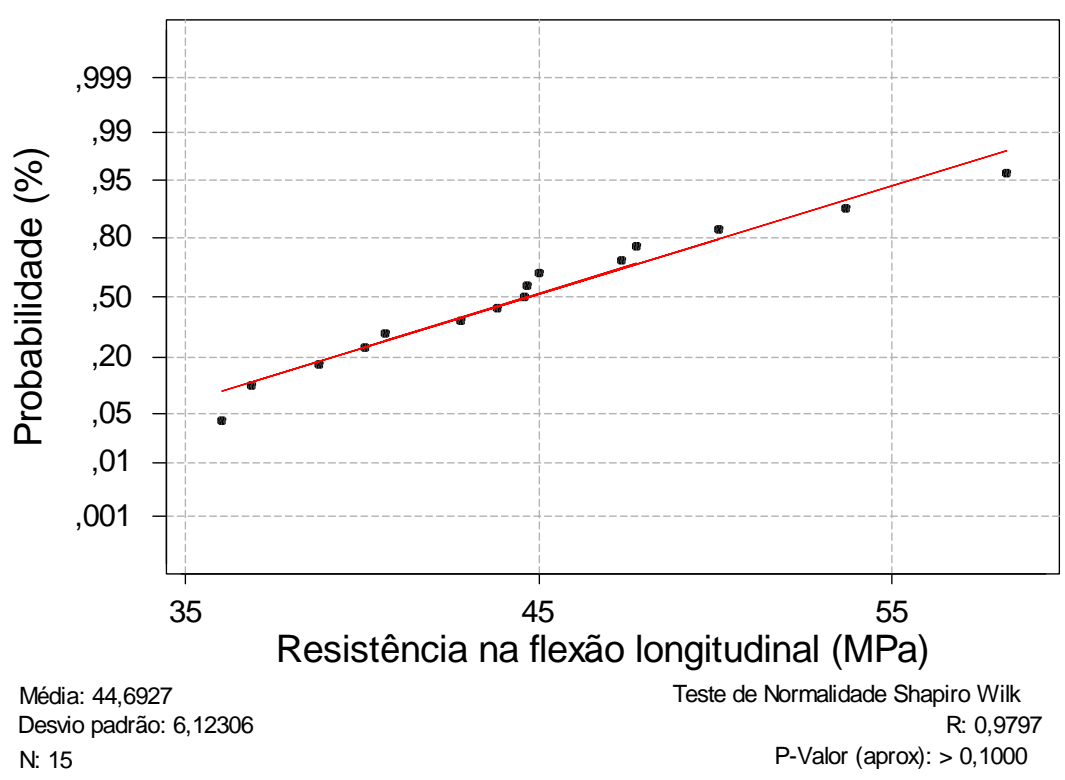

Figura 9.19. Teste de Normalidade para a resistência na flexão longitudinal do compósito orientado de bagaço de cana-de-açúcar, com 10\% de resina poliuretana à base de mamona, em misturador a $130^{\circ} \mathrm{C}$

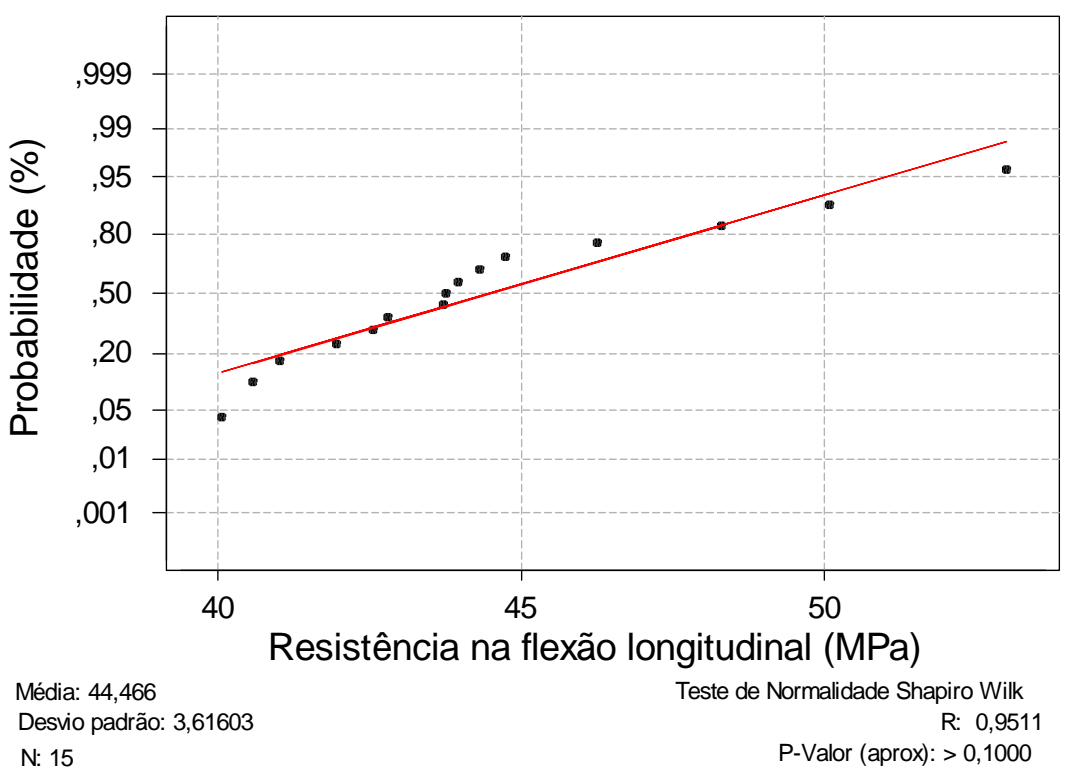

Figura 9.20. Teste de Normalidade para a resistência na flexão longitudinal do compósito orientado de bagaço de cana-de-açúcar, com 10\% de resina Cascomel M $08 \mathrm{ME}$, em misturador a $130^{\circ} \mathrm{C}$ 


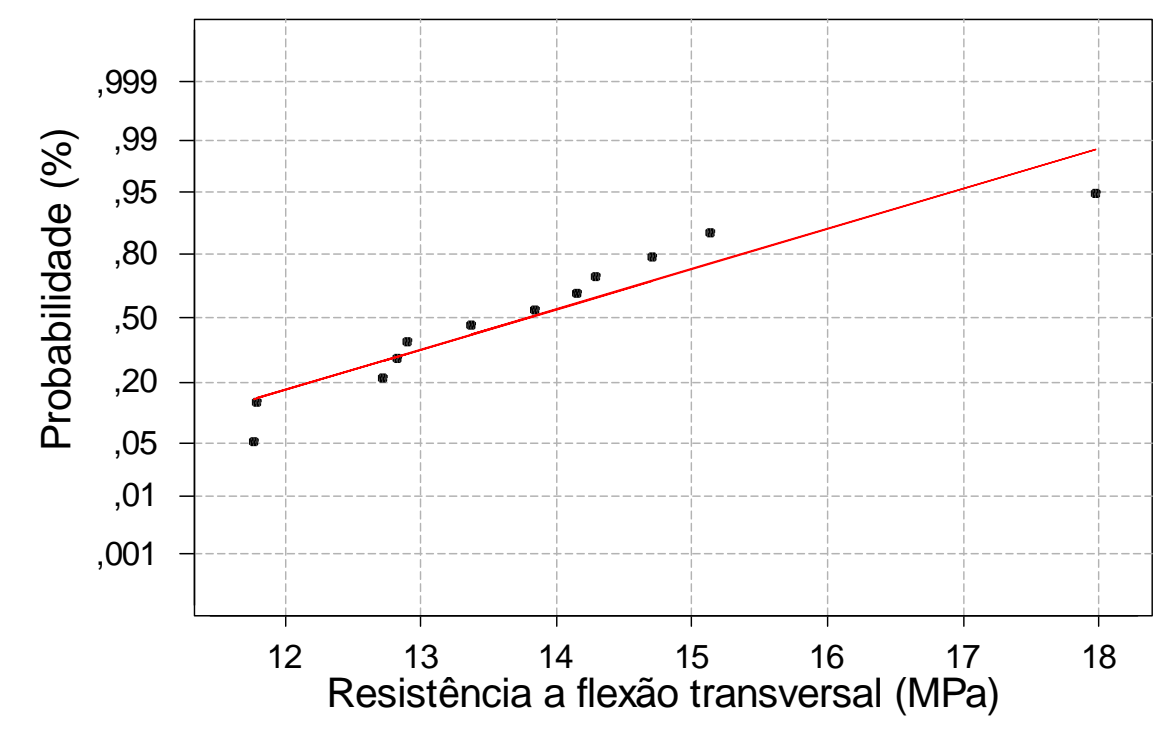

Média: 13,79

Desvio padrão: 1,69871

$\mathrm{N}: 12$

teste de Normalidade Shapiro Wilk

$\mathrm{R}: 0,9426$

P-Valor (aprox): > 0,1000

Figura 9.21. Teste de Normalidade para resistência na flexão transversal do compósito orientado de bagaço de cana-de-açúcar, com 10\% de resina poliuretana

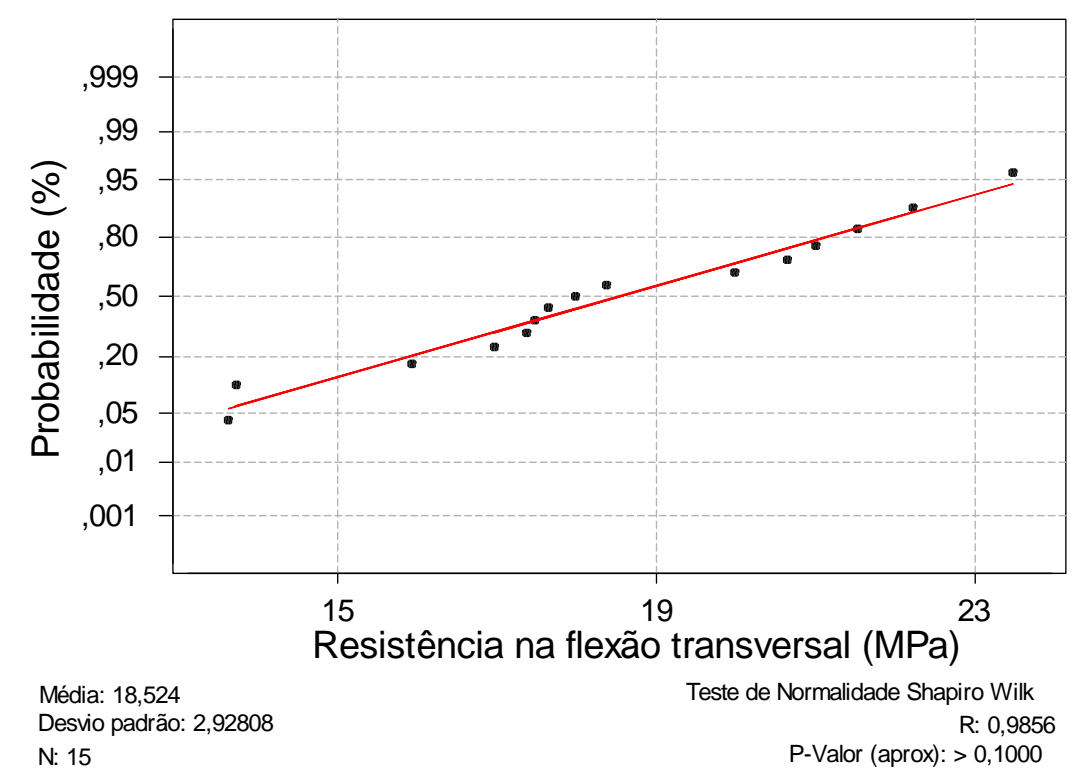

Figura 9.22. Teste de Normalidade para resistência na flexão transversal do compósito orientado de bagaço de cana-de-açúcar, com $10 \%$ de resina poliuretana à base de mamona, em misturador a $90^{\circ} \mathrm{C}$ 


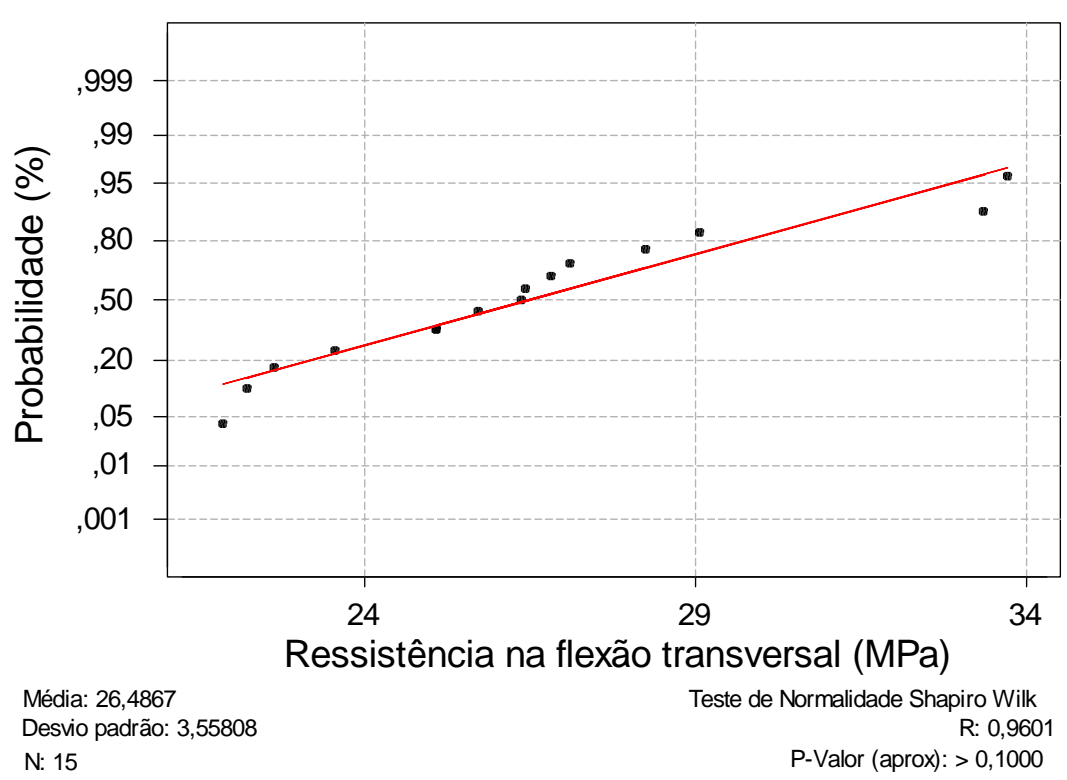

Figura 9.23. Teste de Normalidade para resistência na flexão transversal do compósito orientado de bagaço de cana-de-açúcar, com 10\% de resina poliuretana à base de mamona, em misturador a $130^{\circ} \mathrm{C}$

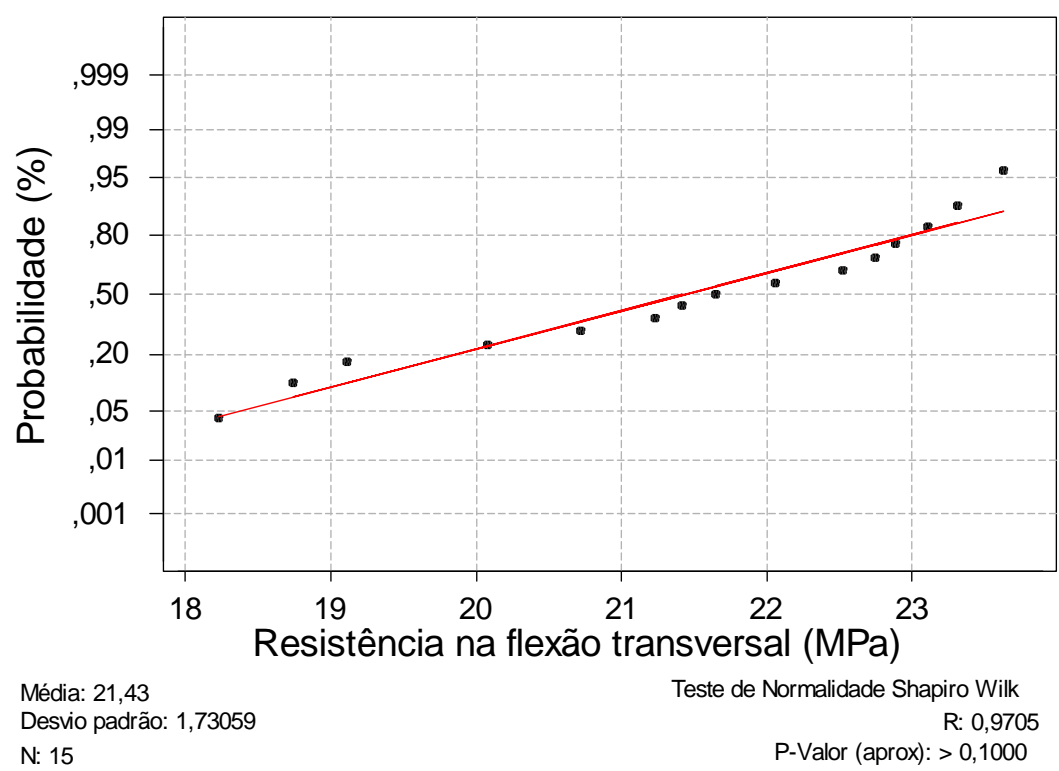

Figura 9.24. Teste de Normalidade para resistência na flexão transversal do compósito orientado de bagaço de cana-de-açúcar, com 10\% de resina Cascomel M $08 \mathrm{ME}$, em misturador a $130^{\circ} \mathrm{C}$ 


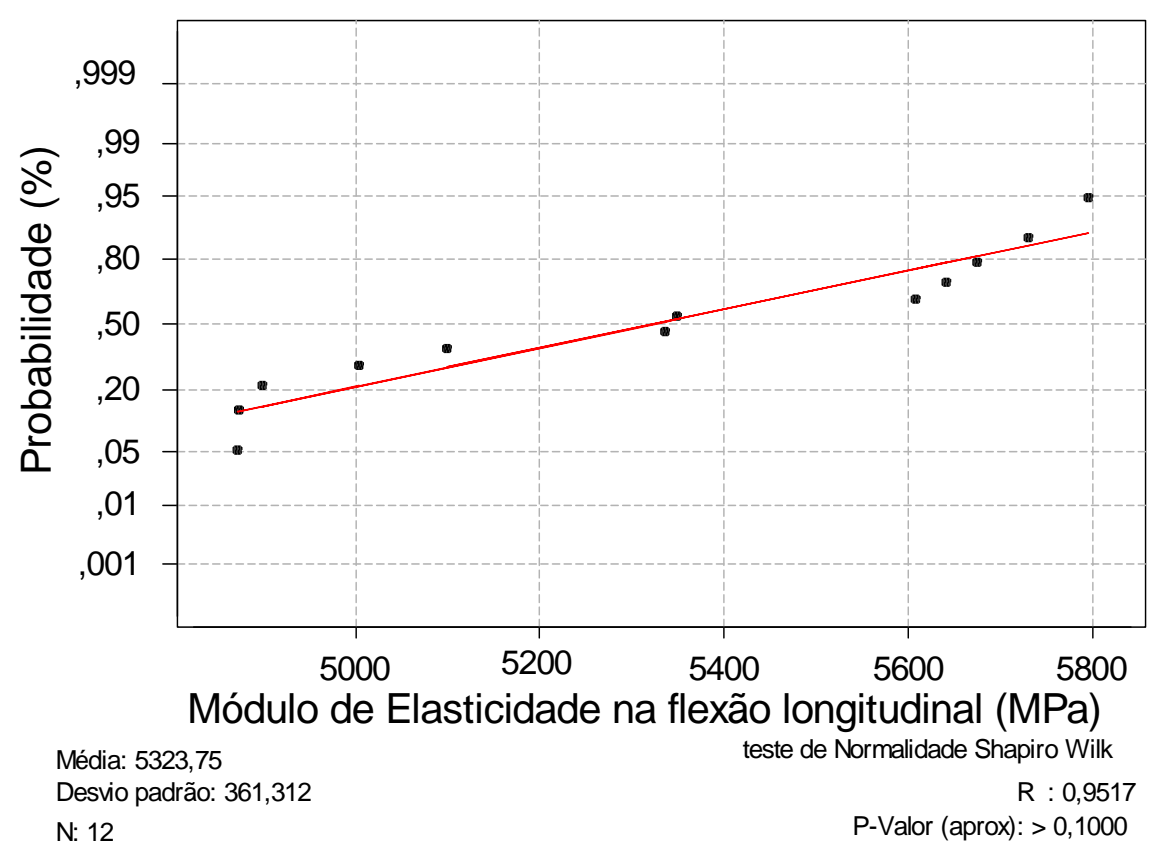

Figura 9.25. Teste de Normalidade no módulo de elasticidade na flexão longitudinal do compósito orientado de bagaço de cana-de-açúcar, com $10 \%$ de resina poliuretana

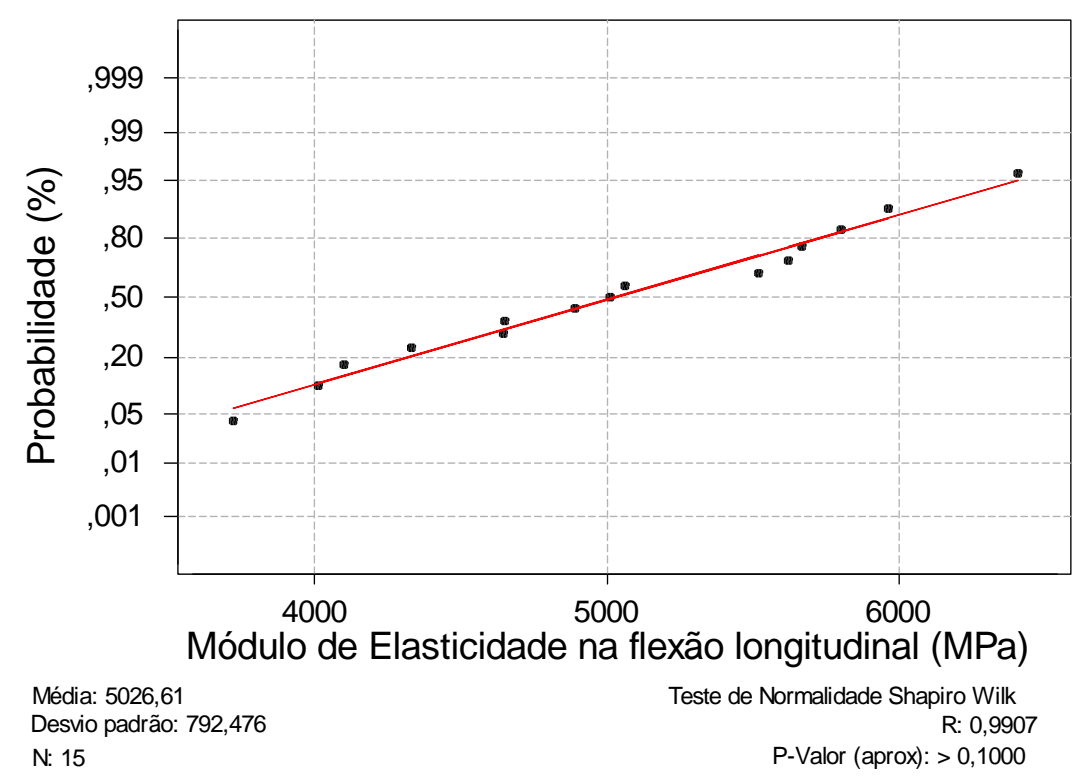

Figura 9.26. Teste de Normalidade no módulo de elasticidade na flexão longitudinal do compósito orientado de bagaço de cana-de-açúcar, com 10\% de resina poliuretana à base de mamona, em misturador a $90^{\circ} \mathrm{C}$ 


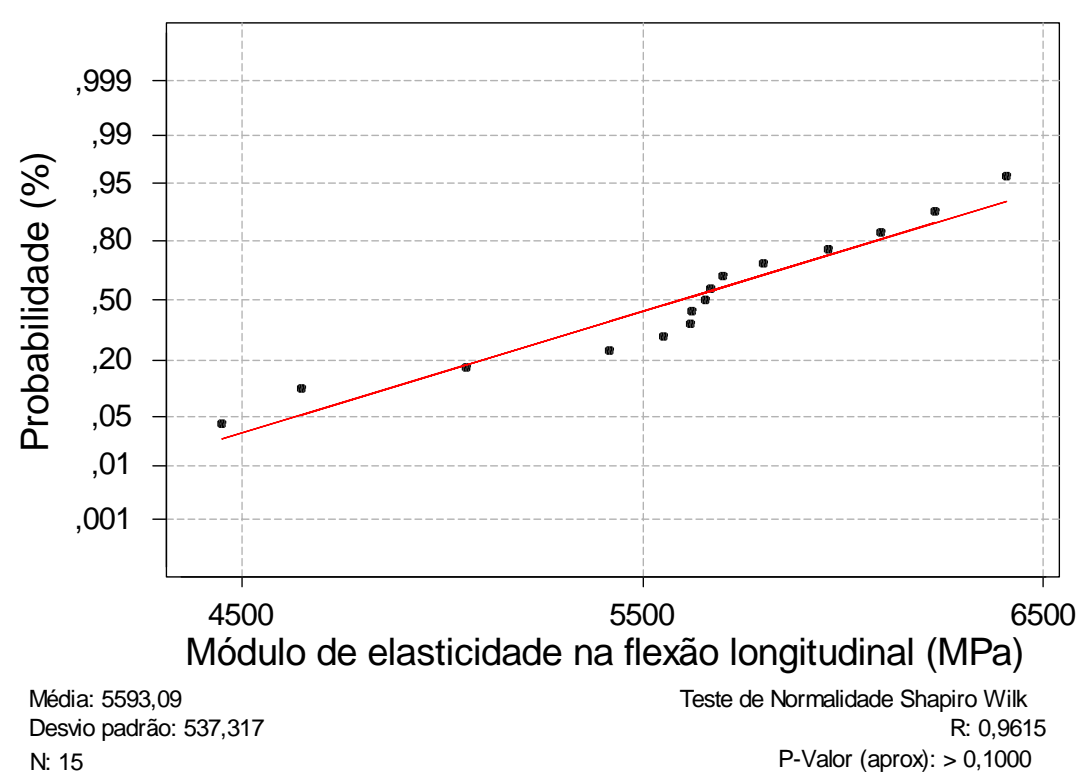

Figura 9.27. Teste de Normalidade no módulo de elasticidade na flexão longitudinal do compósito orientado de bagaço de cana-de-açúcar, com $10 \%$ de resina poliuretana à base de mamona, em misturador a $130^{\circ} \mathrm{C}$

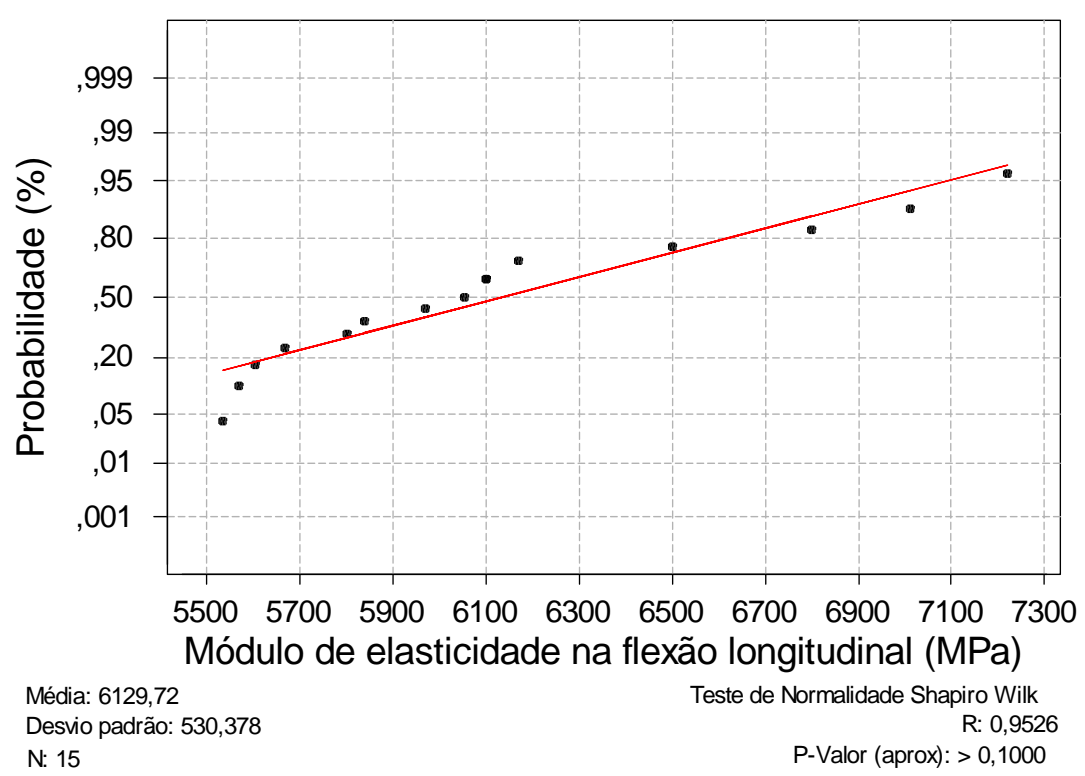

Figura 9.28. Teste de Normalidade no módulo de elasticidade na flexão longitudinal do compósito orientado de bagaço de cana-de-açúcar, com 10\% de resina Cascomel M $08 \mathrm{ME}$, em misturador a $130^{\circ} \mathrm{C}$ 


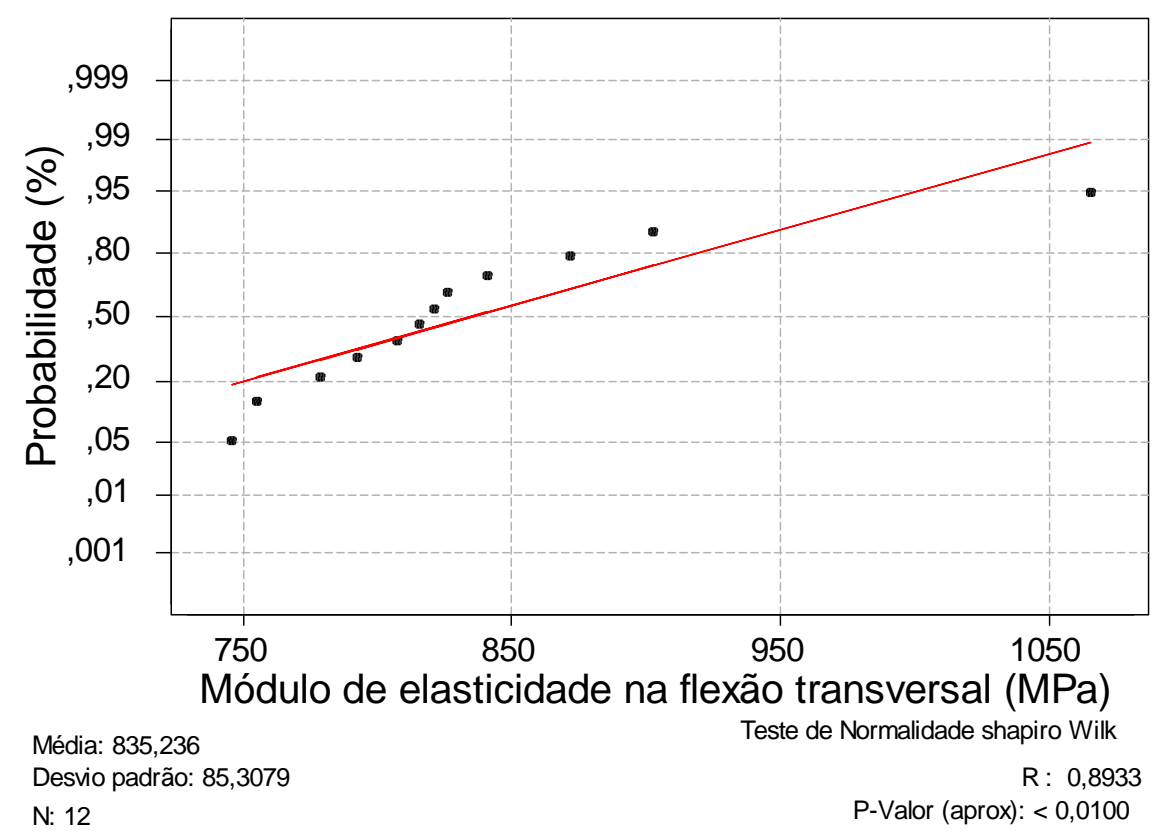

Figura 9.29. Teste de Normalidade no módulo de elasticidade na flexão transversal do compósito orientado de bagaço de cana-de-açúcar, com 10\% de resina poliuretana à base de mamona a $90^{\circ} \mathrm{C}$

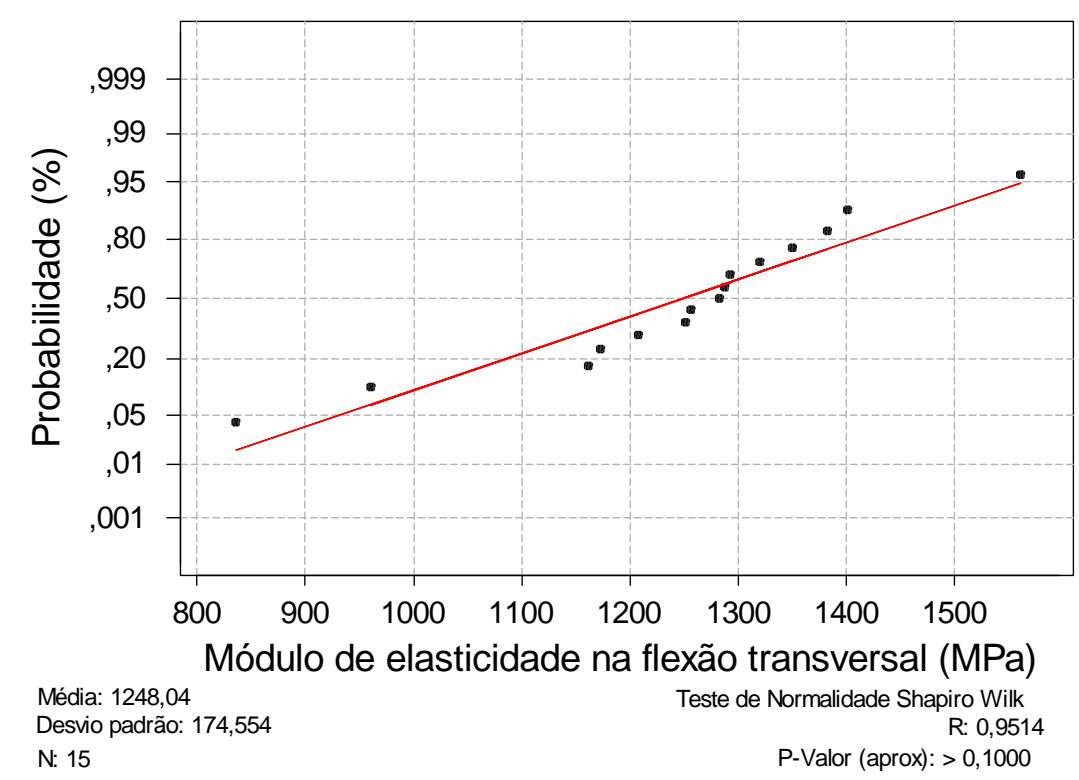

Figura 9.30. Teste de Normalidade no módulo de elasticidade na flexão transversal do compósito orientado de bagaço de cana-de-açúcar, com 10\% de resina poliuretana à base de mamona, em misturador a $90^{\circ} \mathrm{C}$ 


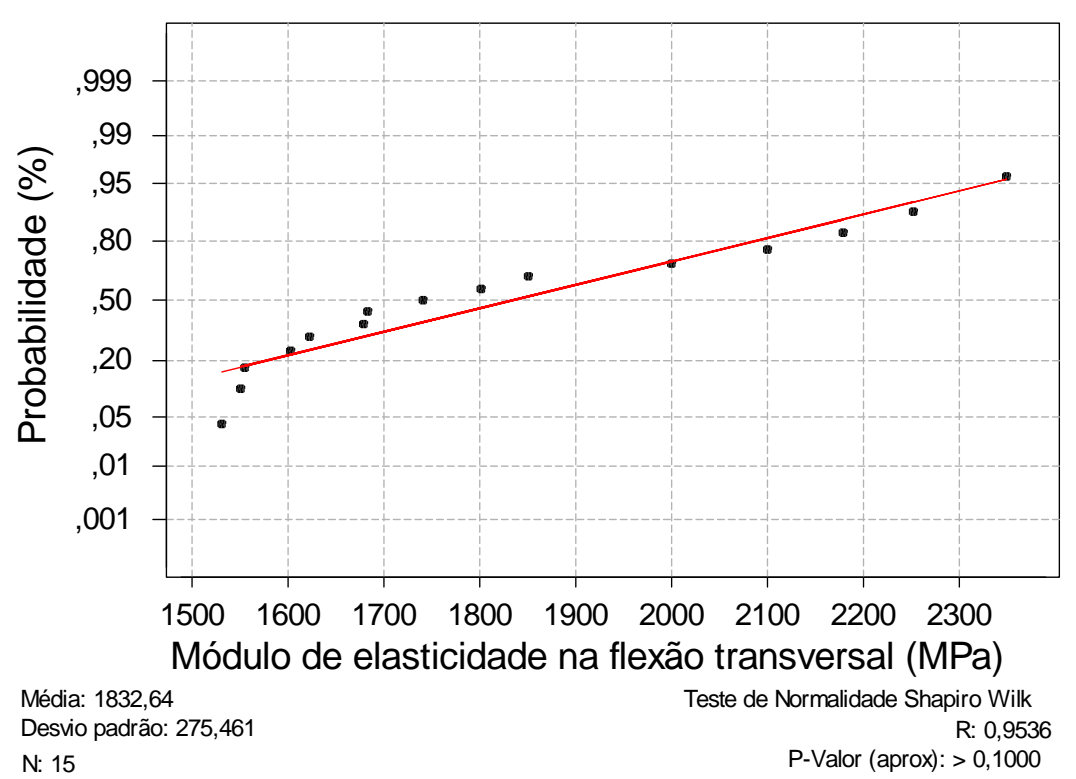

Figura 9.31. Teste de Normalidade no módulo de elasticidade na flexão transversal do compósito orientado de bagaço de cana-de-açúcar, com $10 \%$ de resina poliuretana à base de mamona, em misturador a $130^{\circ} \mathrm{C}$

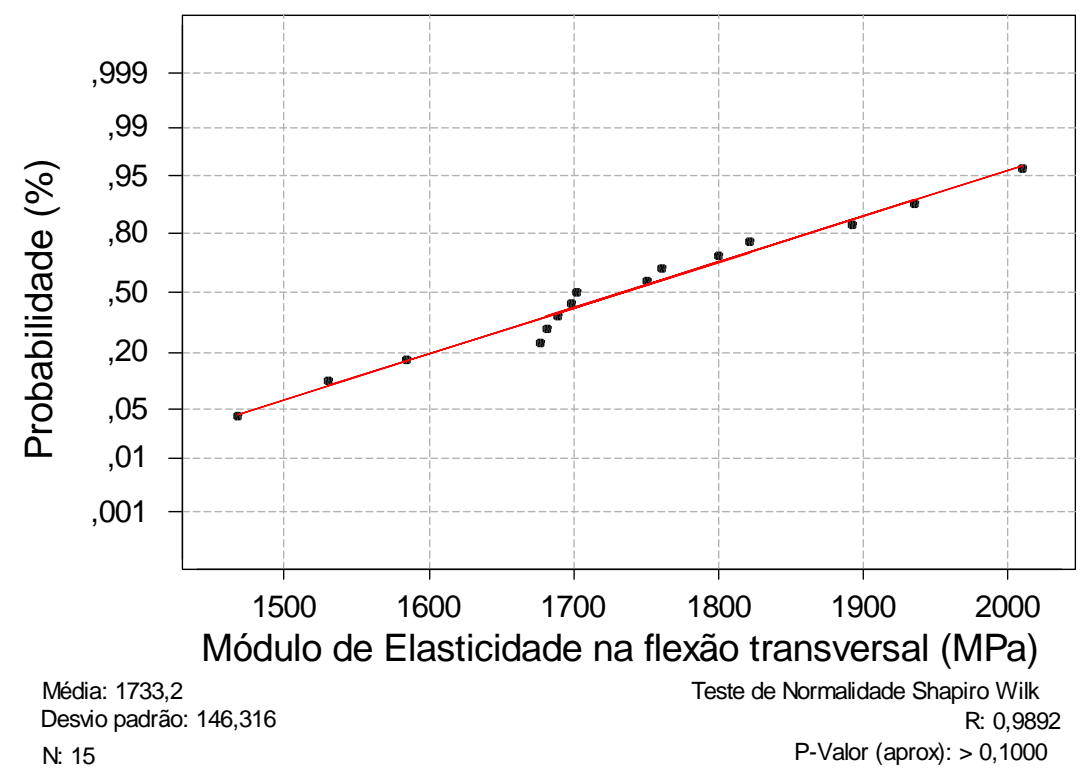

Figura 9.32. Teste de Normalidade no módulo de elasticidade na flexão transversal do compósito orientado de bagaço de cana-de-açúcar, com 10\% de resina Cascomel M $08 \mathrm{ME}$, em misturador a $130^{\circ} \mathrm{C}$ 


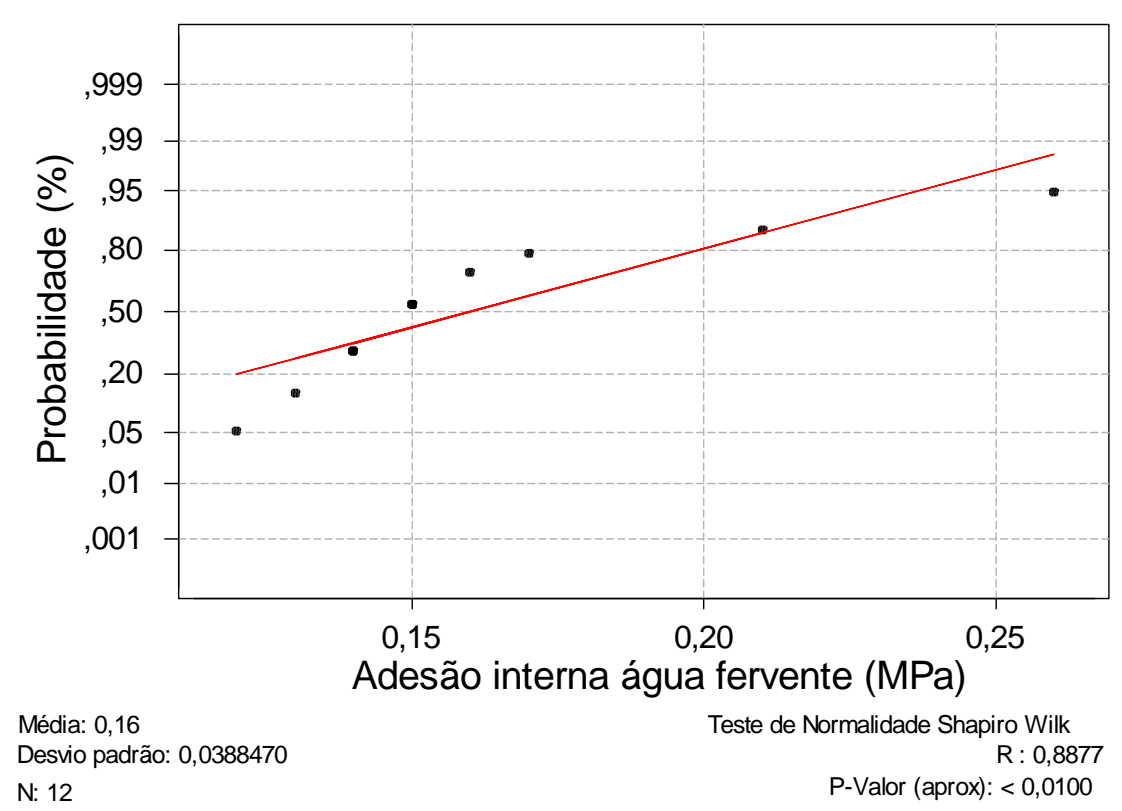

Figura 9.33. Teste de Normalidade na adesão interna em água fervente (ensaio cíclico) do compósito orientado de bagaço de cana-de-açúcar, com 10\% de resina poliuretana à base de mamona a $90^{\circ} \mathrm{C}$

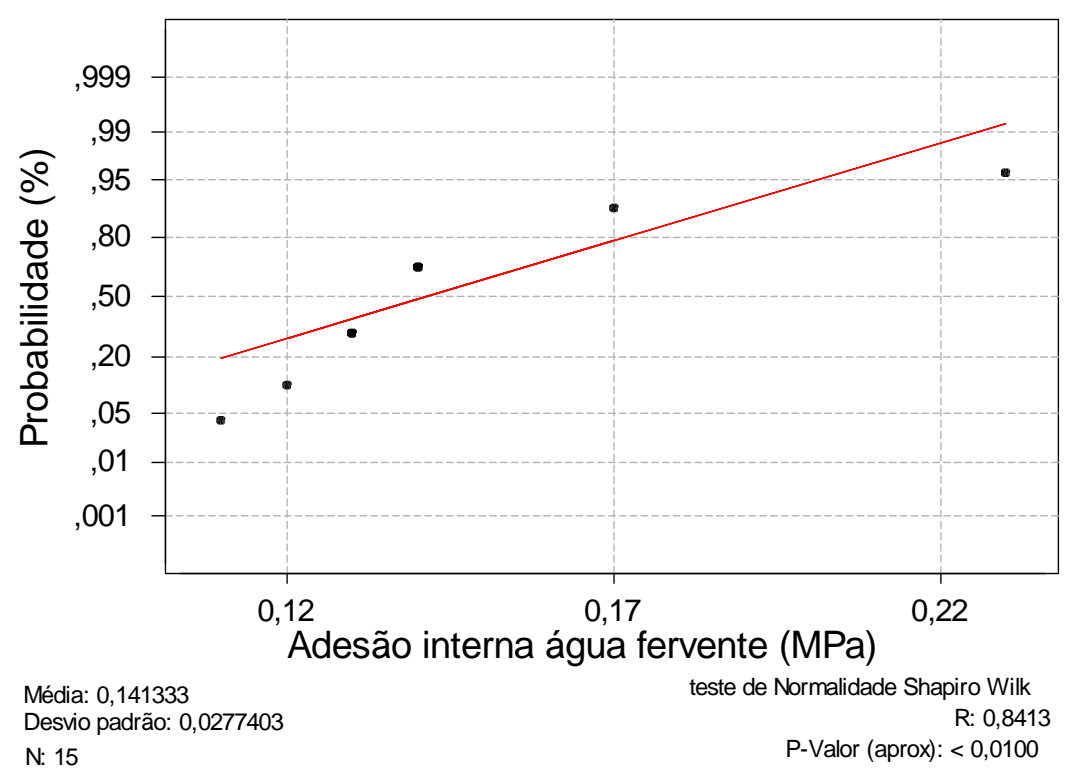

Figura 9.34. Teste de Normalidade na adesão interna em água fervente (ensaio cíclico) do compósito orientado de bagaço de cana-de-açúcar, com 10\% de resina poliuretana à base de mamona, em misturador a $90^{\circ} \mathrm{C}$ 


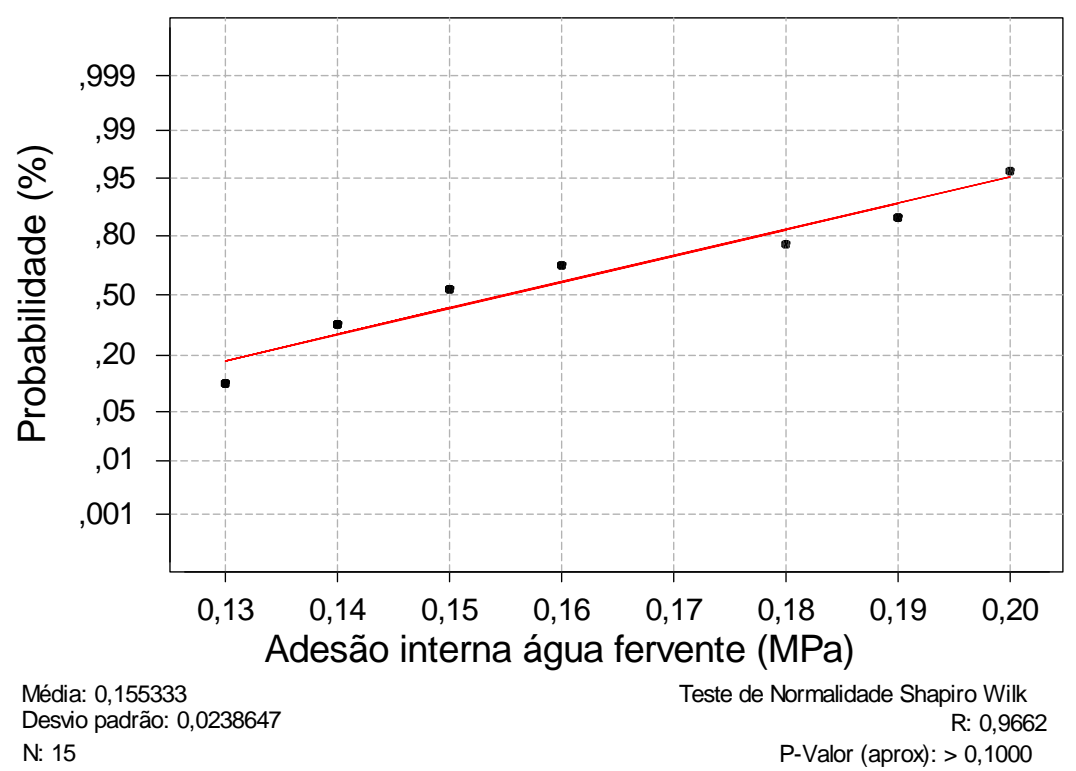

Figura 9.35. Teste de Normalidade na adesão interna em água fervente (ensaio cíclico) do compósito orientado de bagaço de cana-de-açúcar, com 10\% de resina poliuretana à base de mamona, em misturador a $130^{\circ} \mathrm{C}$

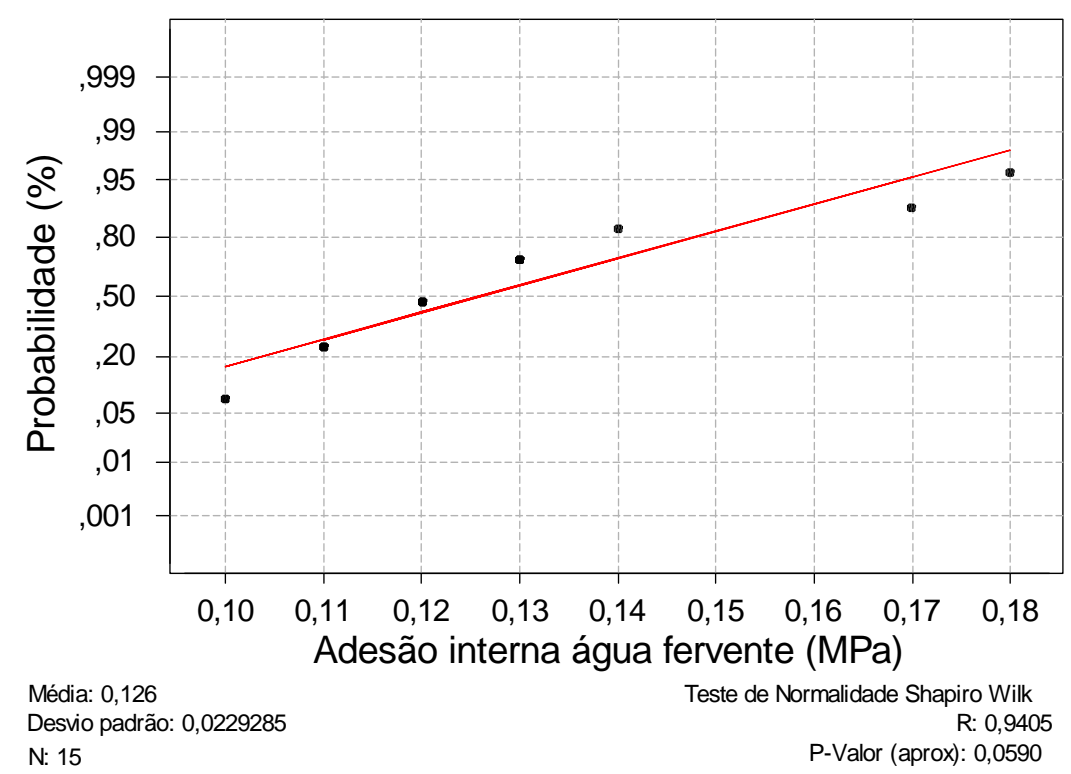

Figura 9.36. Teste de Normalidade na adesão interna em água fervente (ensaio cíclico) do compósito orientado de bagaço de cana-de-açúcar, com 10\% de resina Cascomel M $08 \mathrm{ME}$, em misturador a $130^{\circ} \mathrm{C}$ 


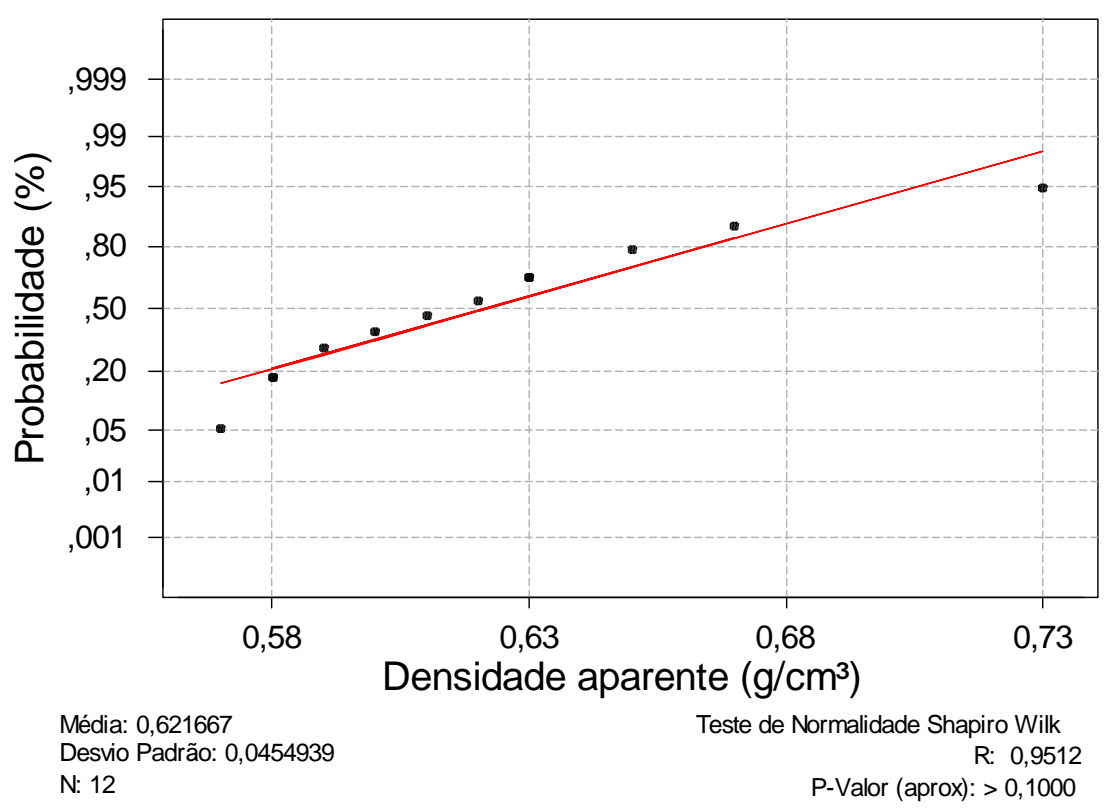

Figura 9.37. Teste de Normalidade para densidade aparente do compósito orientado de bagaço de cana-de-açúcar, com 20\% de resina poliuretana à base de mamona

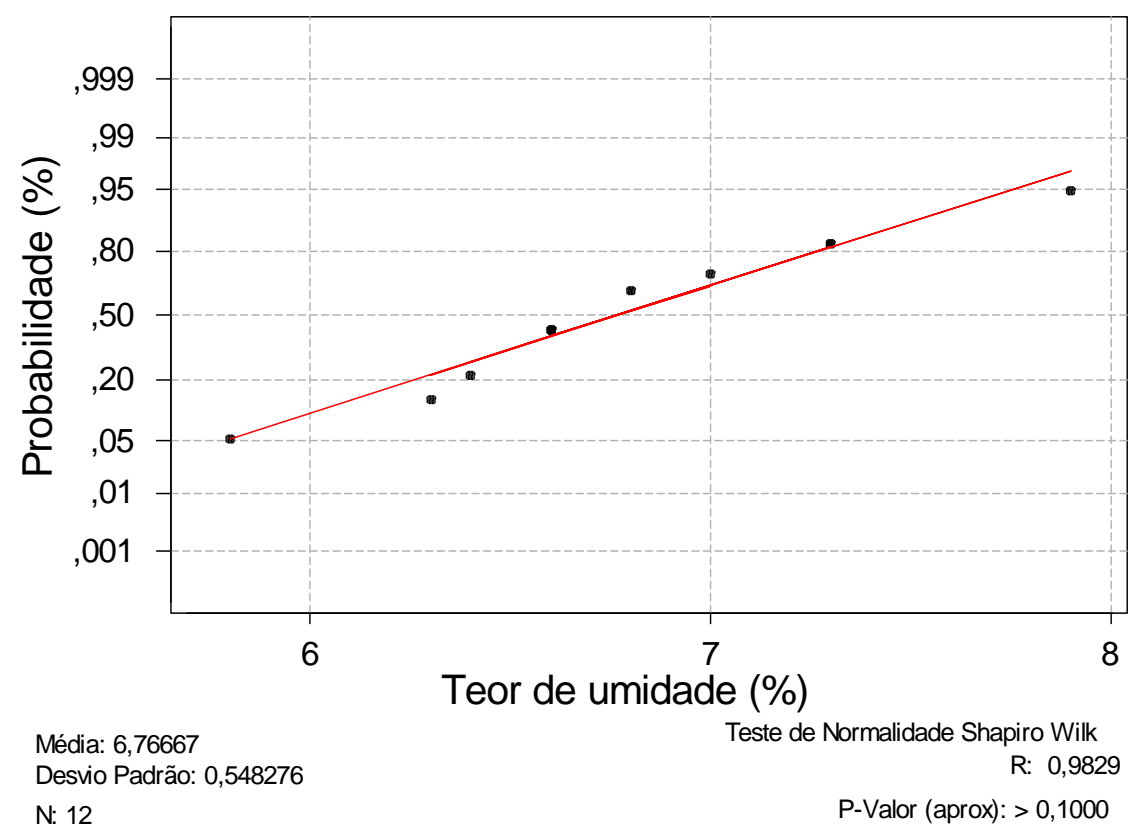

Figura 9.38. Teste de Normalidade para o teor de umidade do compósito orientado de bagaço de cana-de-açúcar, com 20\% de resina poliuretana à base de mamona 


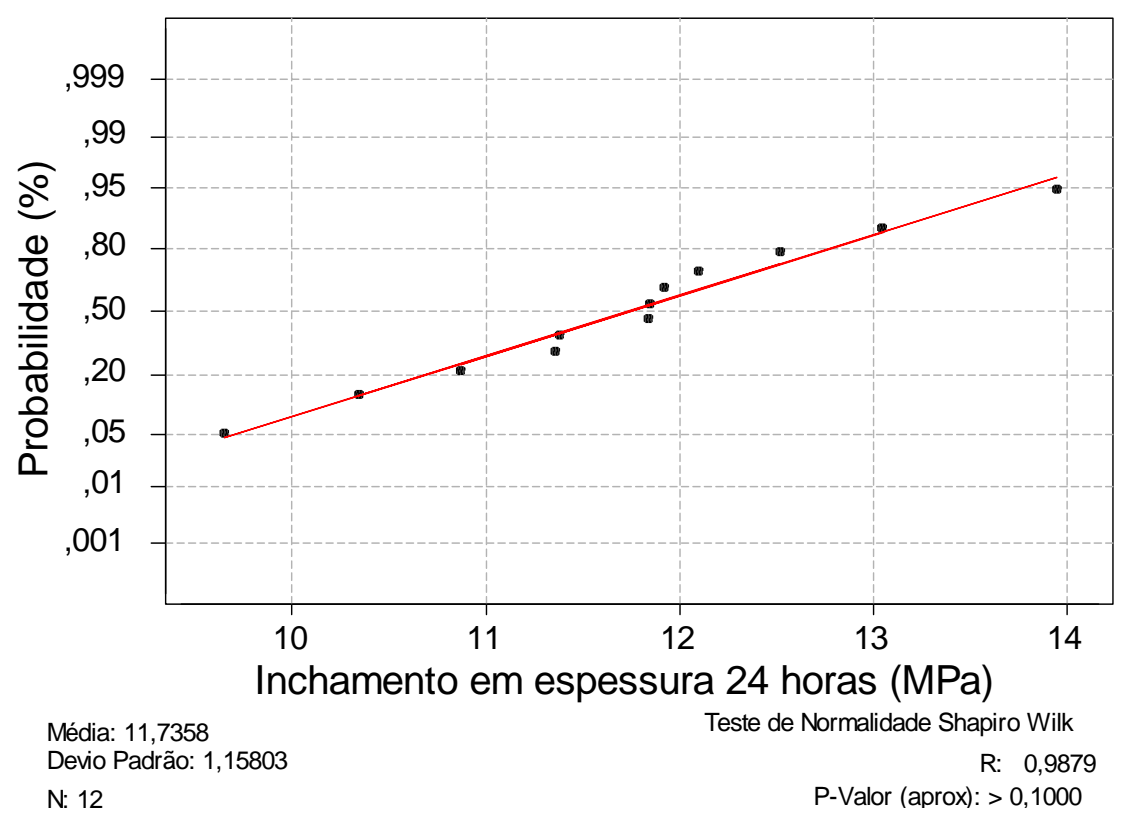

Figura 9.39. Teste de Normalidade para Inchamento em espessura 24 horas do compósito orientado de bagaço de cana-de-açúcar, com $20 \%$ de resina poliuretana à base de mamona

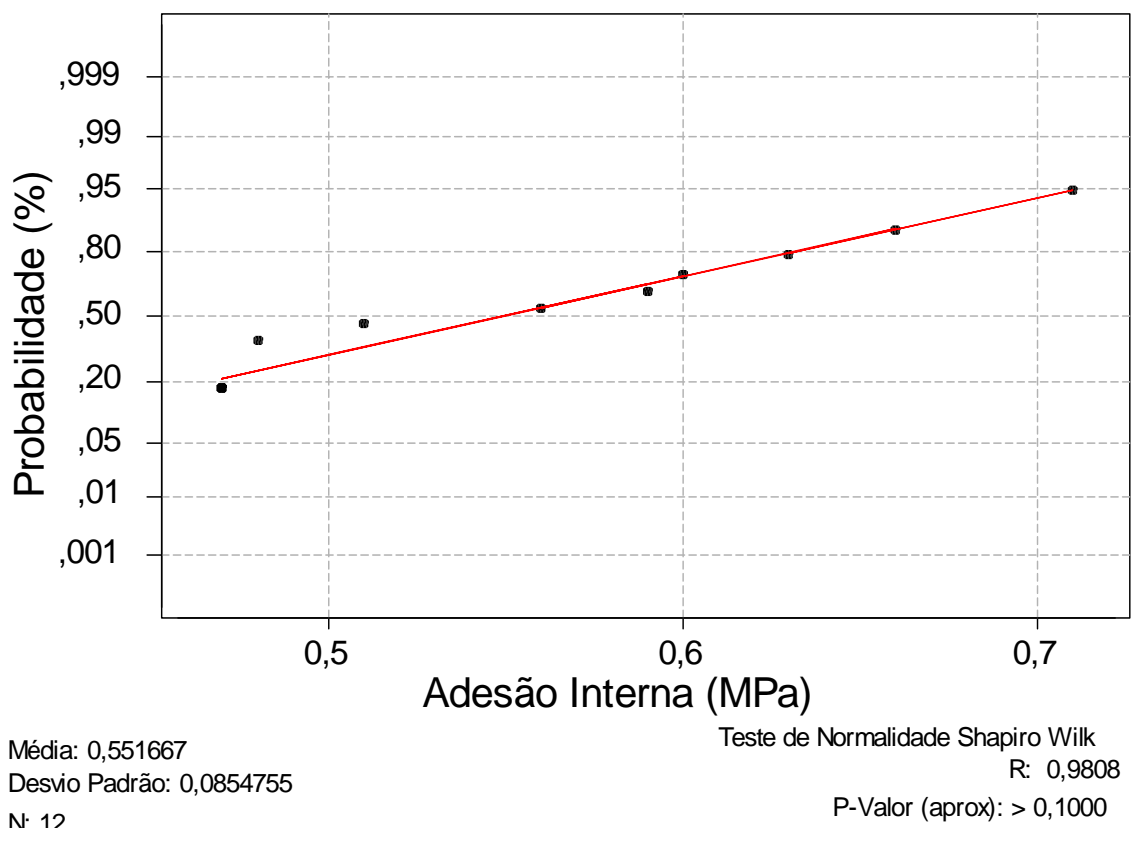

Figura 9.40. Teste de Normalidade para Adesão interna do compósito orientado de bagaço de cana-de-açúcar, com 20\% de resina poliuretana à base de mamona 


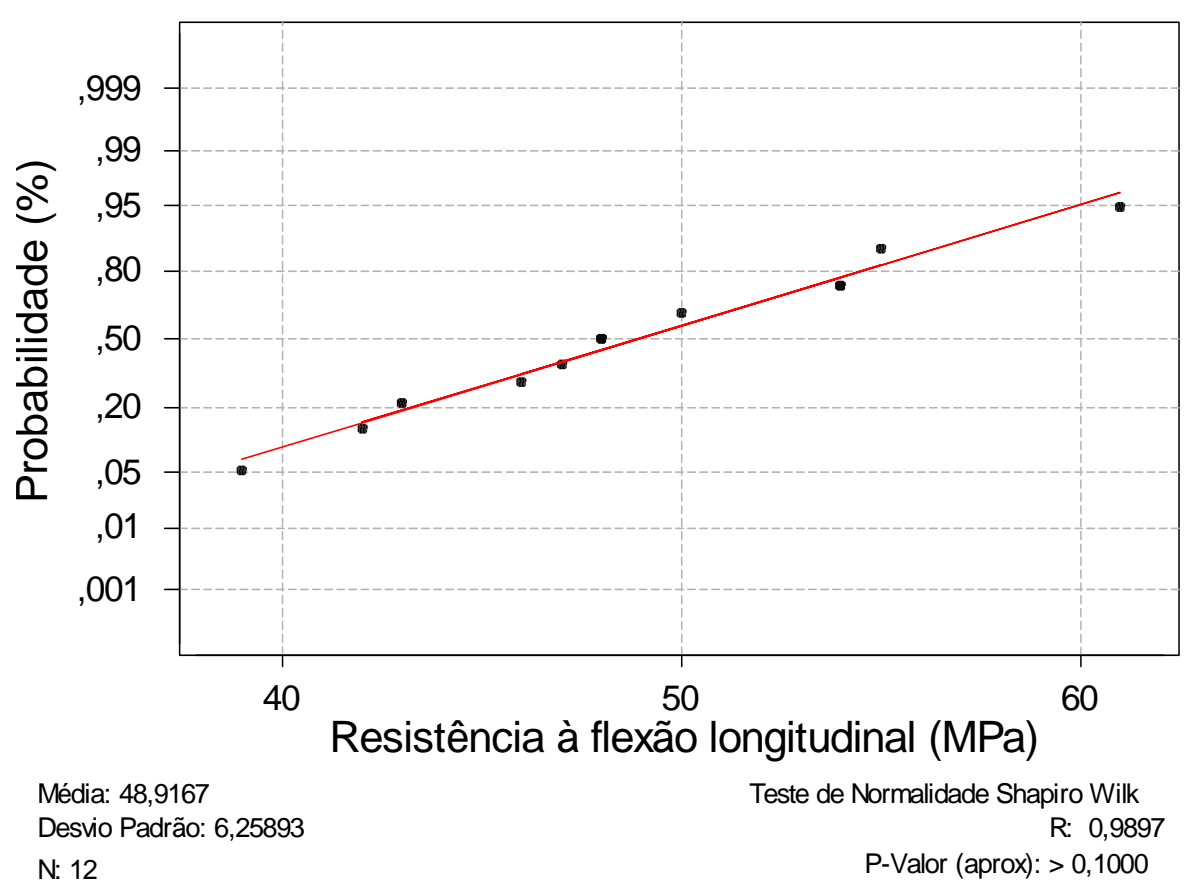

Figura 9.41. Teste de Normalidade para a resistência na flexão longitudinal do compósito orientado de bagaço de cana-de-açúcar, com $20 \%$ de resina poliuretana à base de mamona

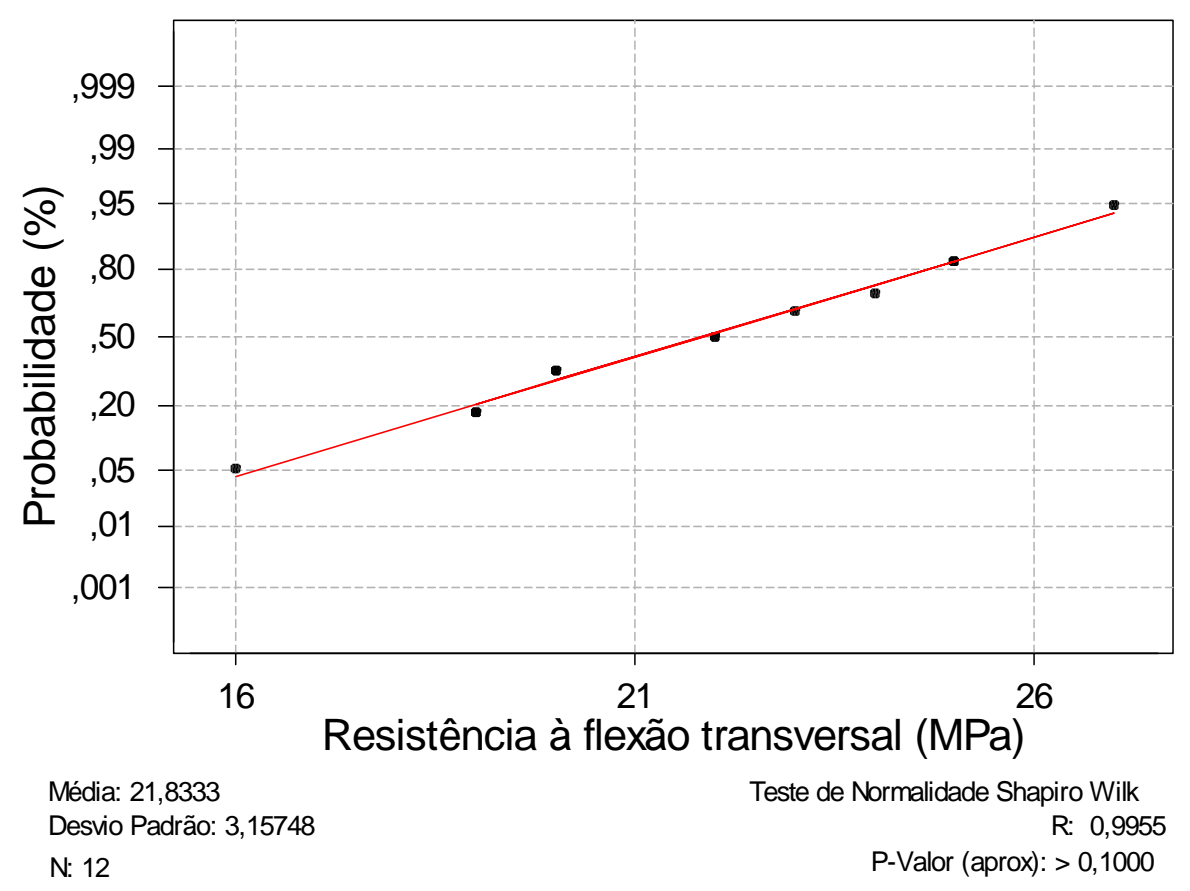

Figura 9.42. Teste de Normalidade para resistência na flexão transversal do compósito orientado de bagaço de cana-de-açúcar, com $20 \%$ de resina poliuretana à base de mamona 


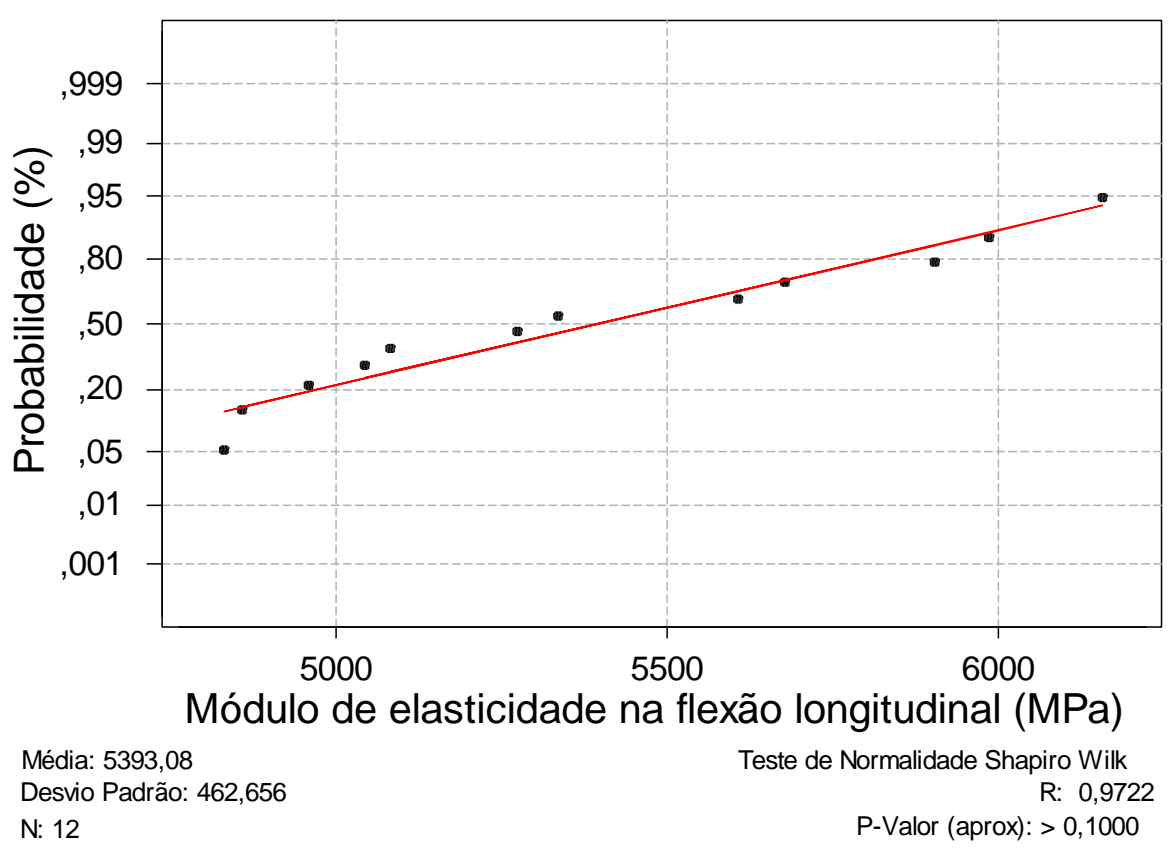

Figura 9.43. Teste de Normalidade para o Módulo de elasticidade na flexão longitudinal do compósito orientado de bagaço de cana-de-açúcar, com 20\% de resina poliuretana à base de mamona

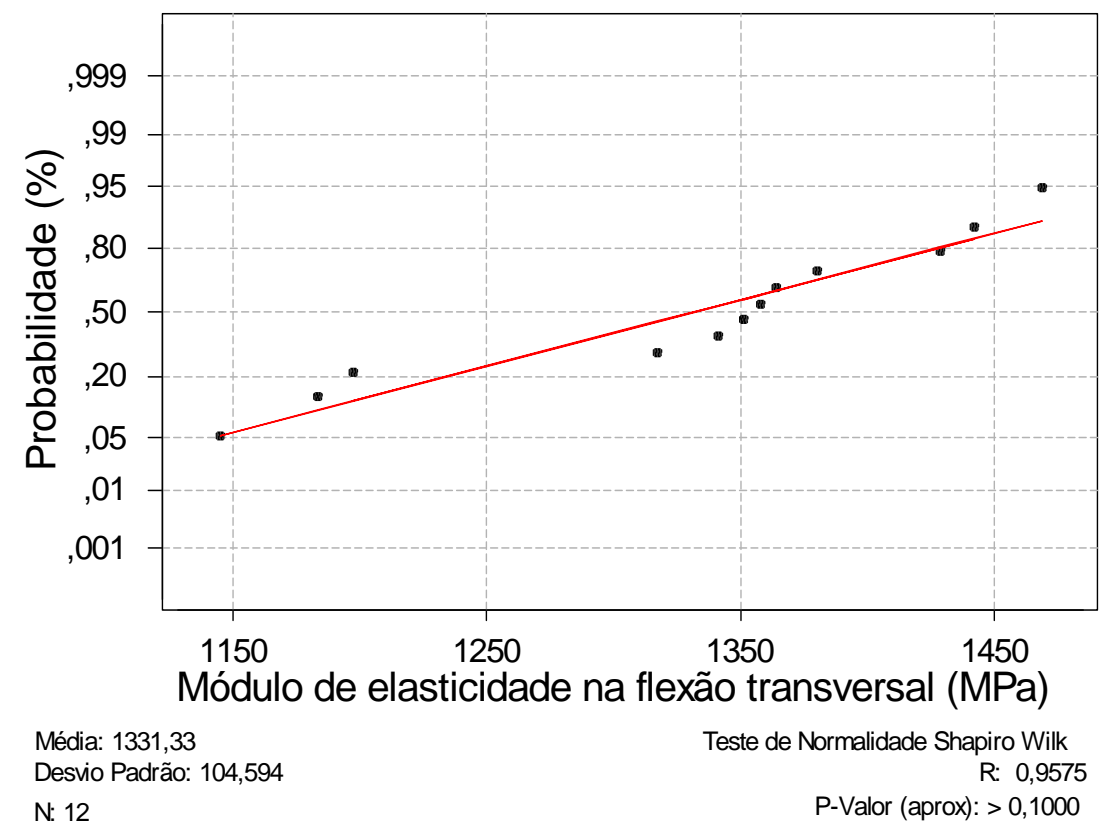

Figura 9.44. Teste de Normalidade para o Módulo de elasticidade na flexão transversal do compósito orientado de bagaço de cana-de-açúcar com 20\% de resina poliuretana à base de mamona 


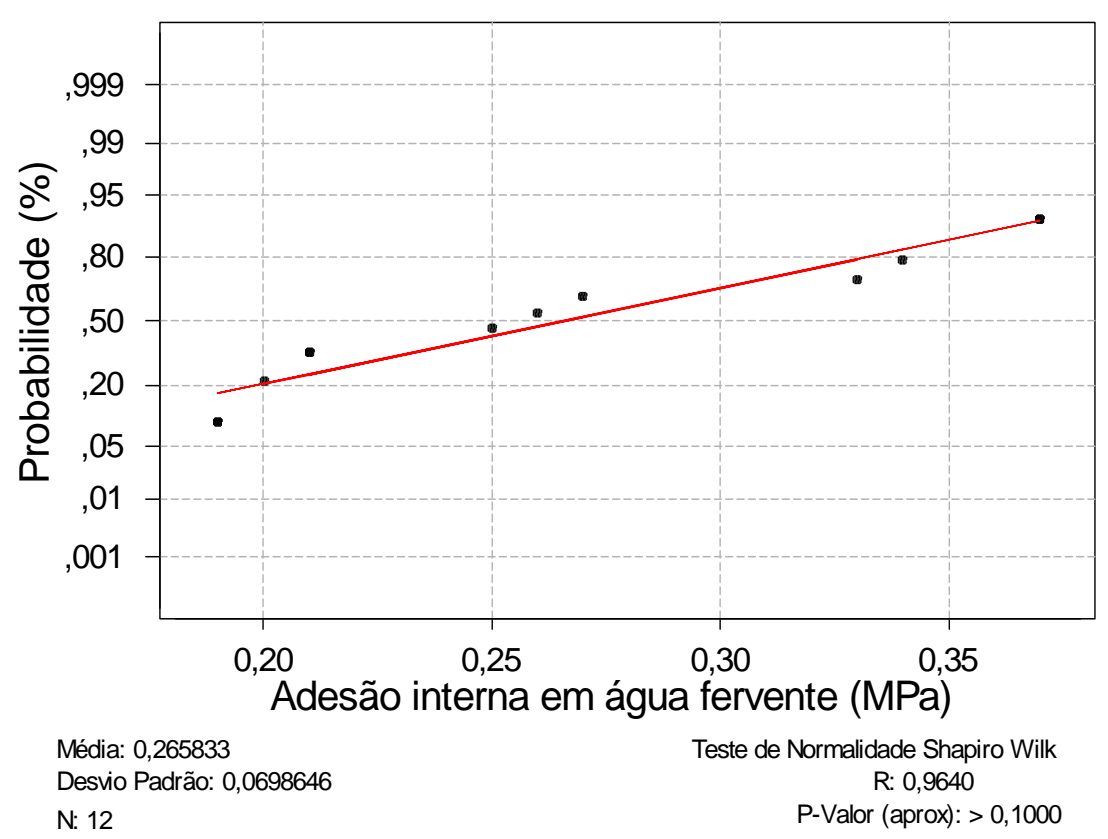

Figura 9.45. Teste de Normalidade na adesão interna em água fervente (ensaio cíclico) do compósito orientado de bagaço de cana-de-açúcar, com 20\% de resina poliuretana à base de mamona 


\section{SEQUÊNCIA ILUSTRADA DO PROCESSO}

Neste item segui-se seqüência ilustrada do processo de fabricação dos painéis de partículas longas e orientada de bagaço de cana.

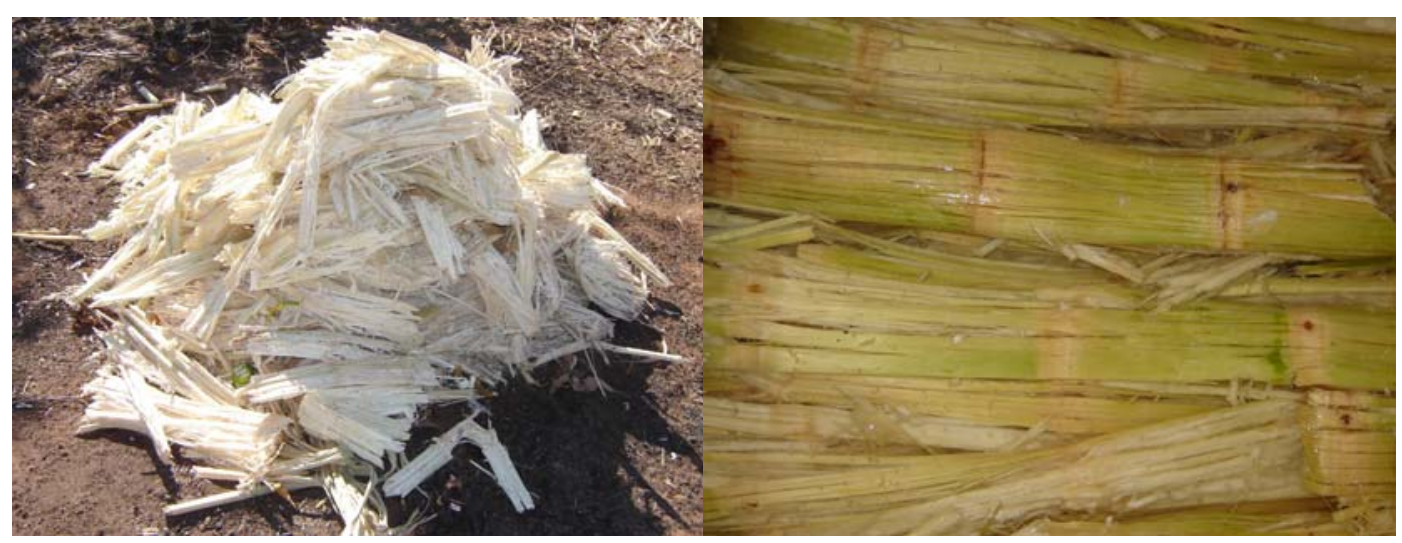

Figura 10.1. Bagaço de cana exposto próximo a moenda e em tanque para tratamento com água

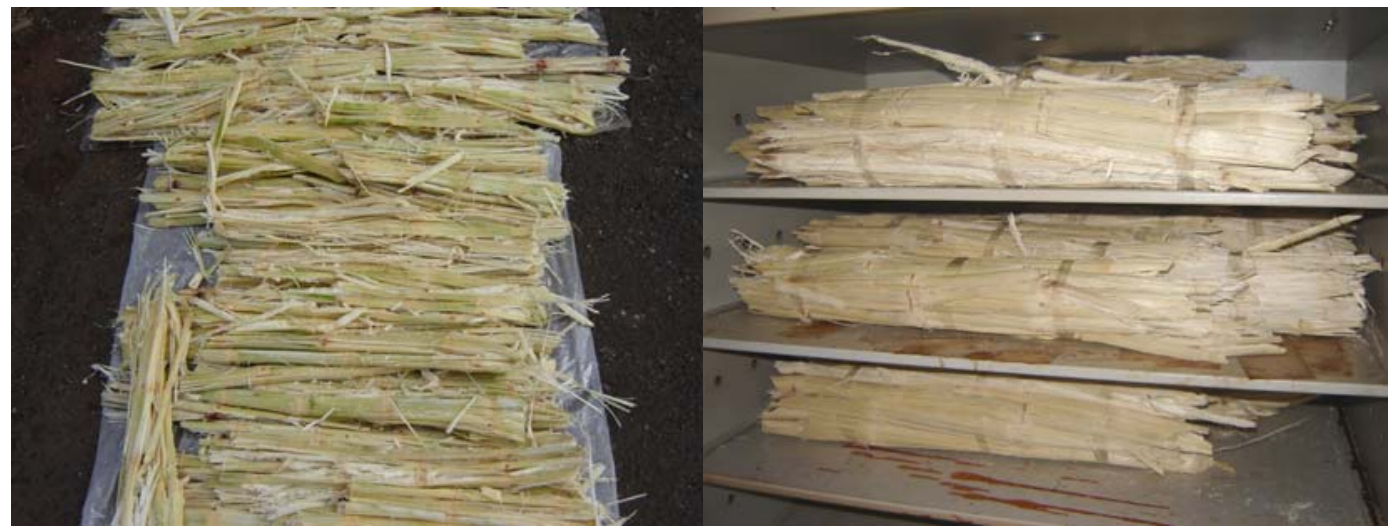

Figura 10.2. Bagaço de cana disposto em secagem natural e em estufa a $60^{\circ} \mathrm{C}$ 


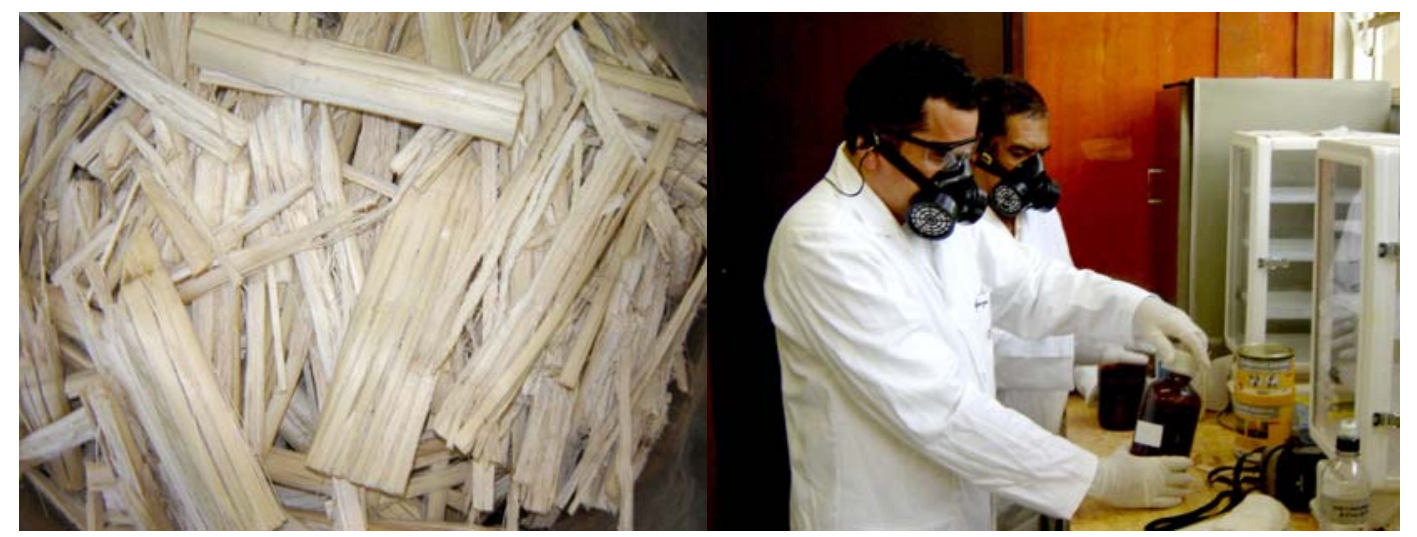

Figura 10.3. Partículas longas de bagaço de cana e preparo da resina a base de mamona para fabricação dos painéis

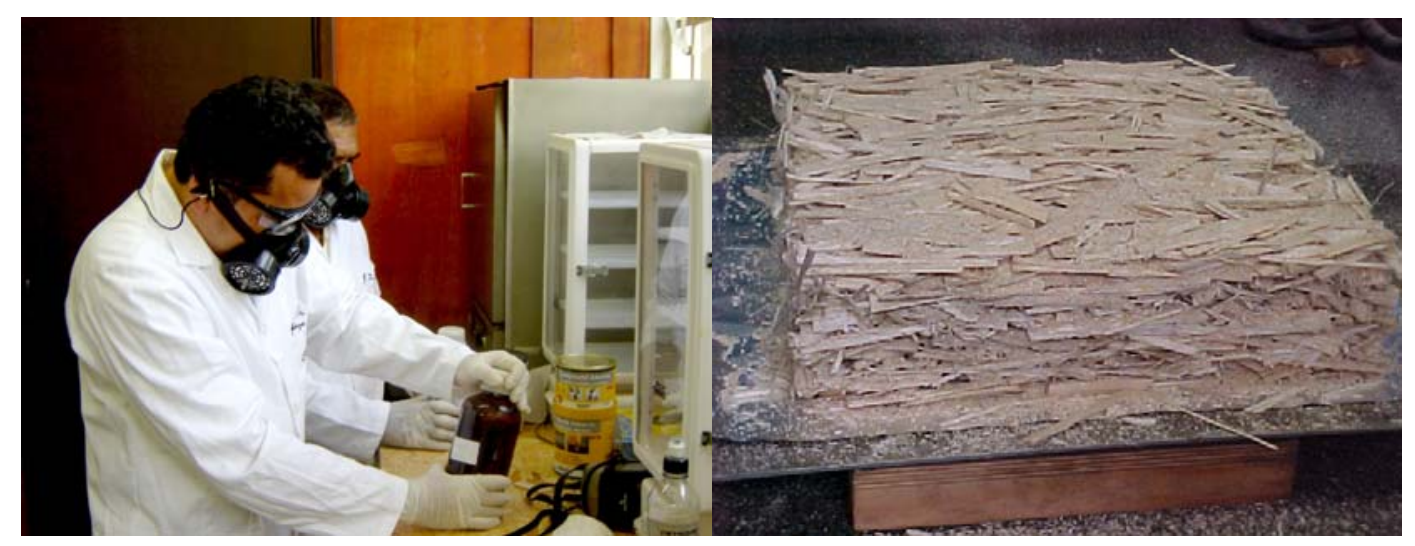

Figura 10.4. Preparo e confecção do colchão em camadas de partículas longas orientadas

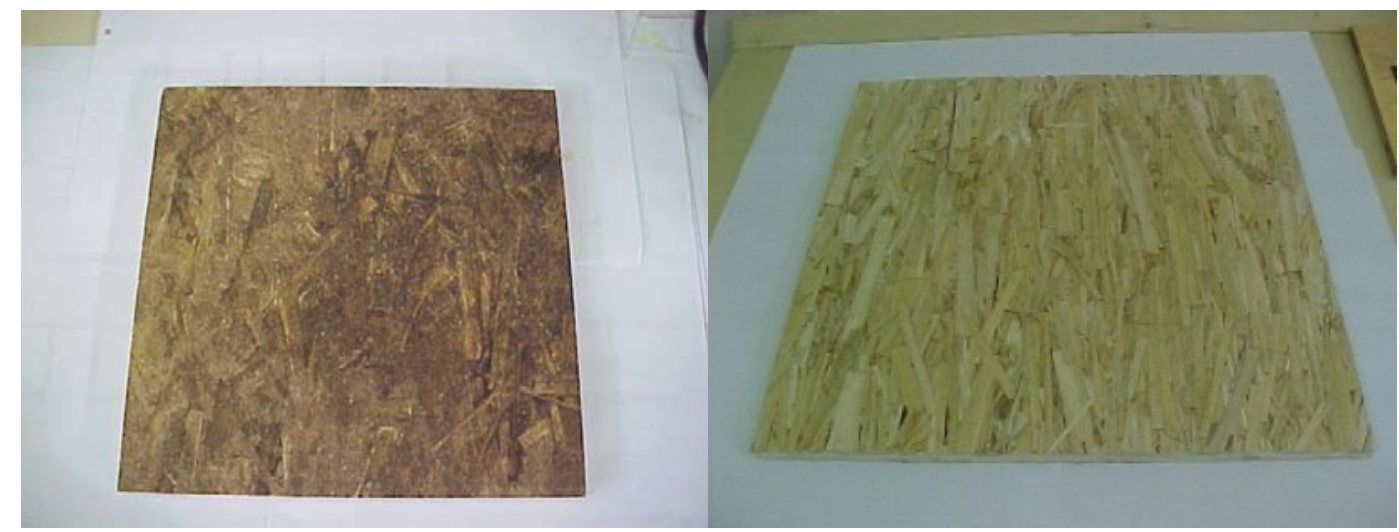

Figura 10.5. Painel confeccionado a $200^{\circ} \mathrm{C}$ com fragmentos de inicio de queima e a direita o painel a $90^{\circ} \mathrm{C}$, com características adequadas para confecção tipo OSB 


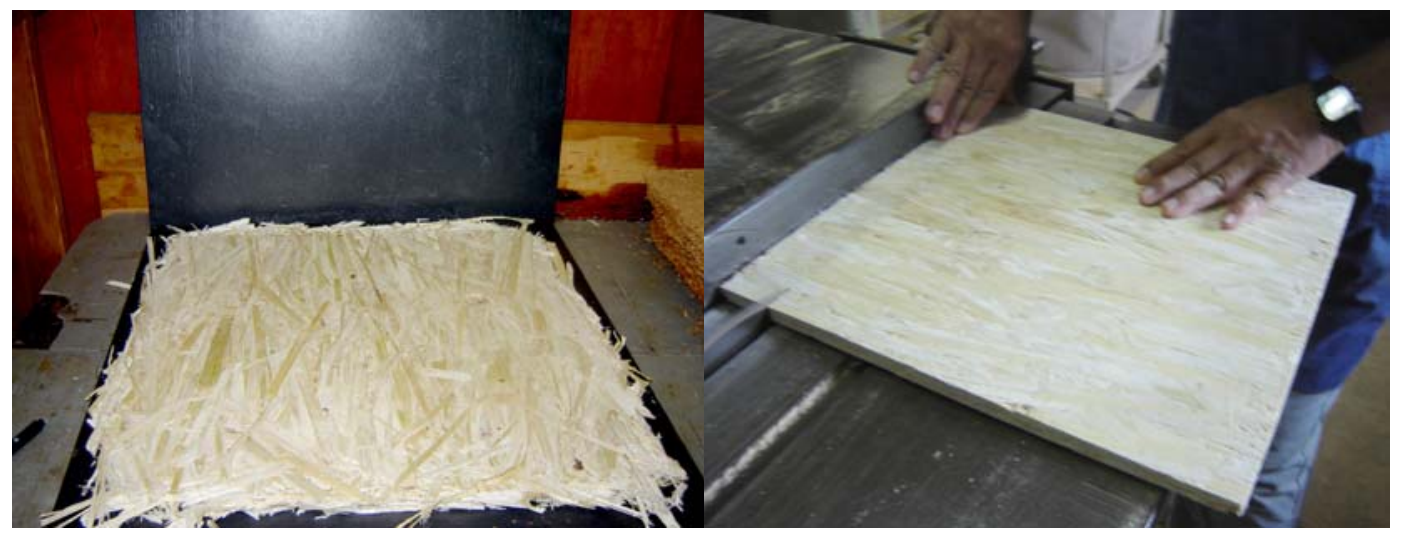

Figura 10.6. Painel após prensagem a quente com chapas teflonadas e serrado nas bordas, dando acabamento

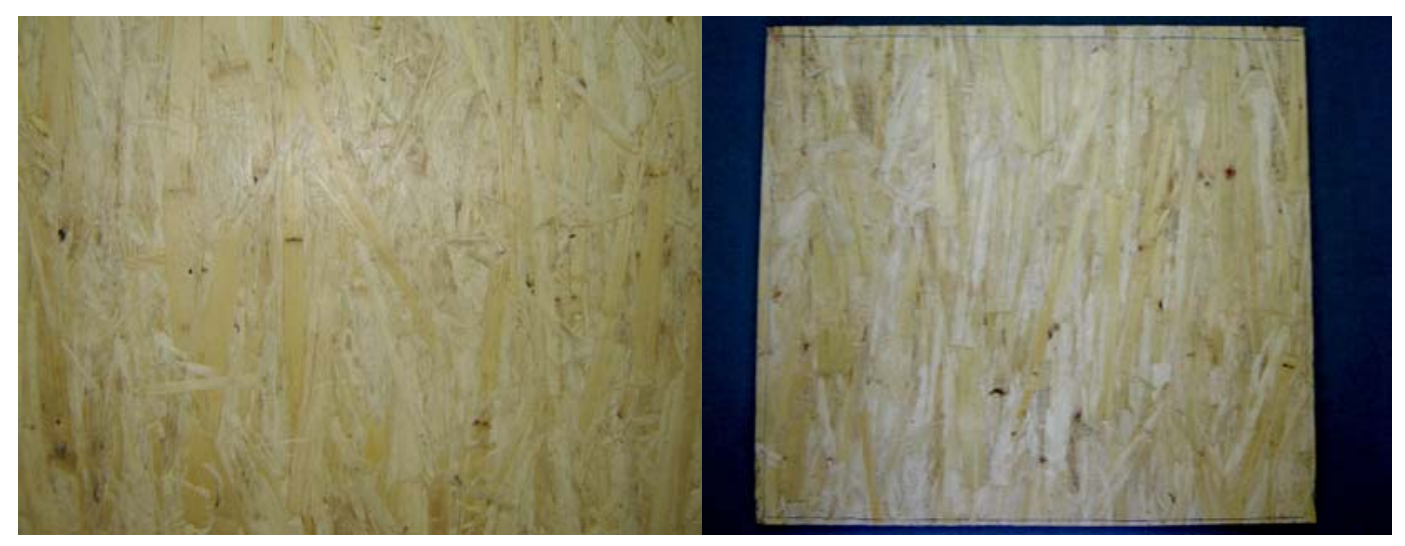

Figura 10.7. Painéis pronto para estocagem para cura

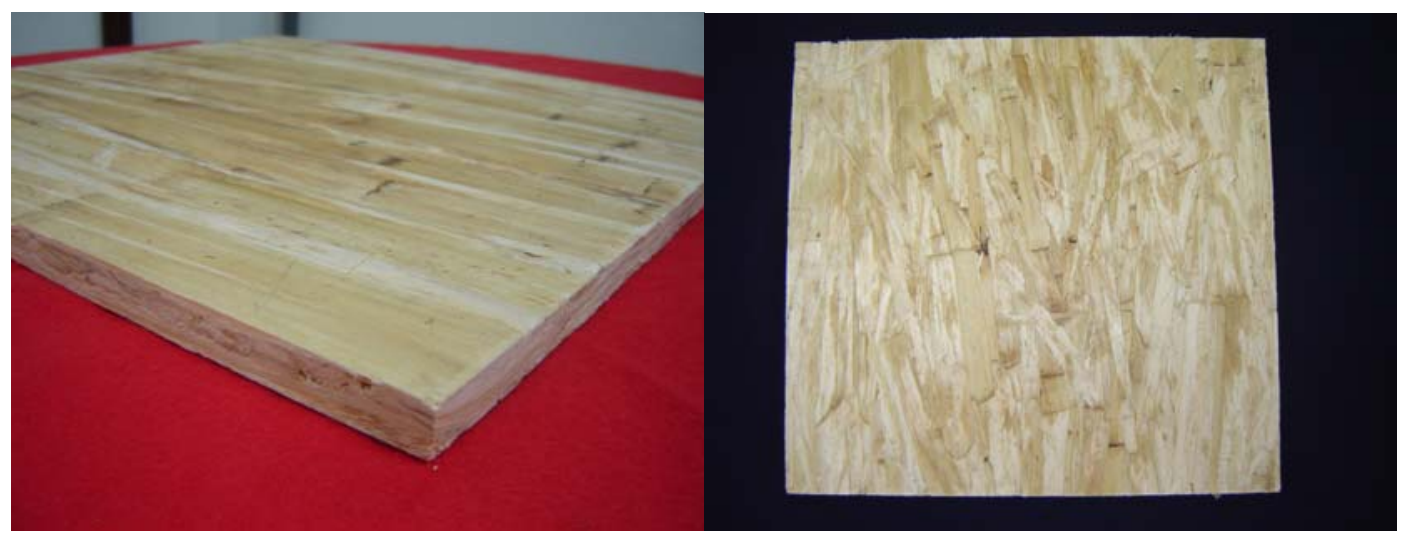

Figura 10.8. Vista em relevo do painel e vista de topo 


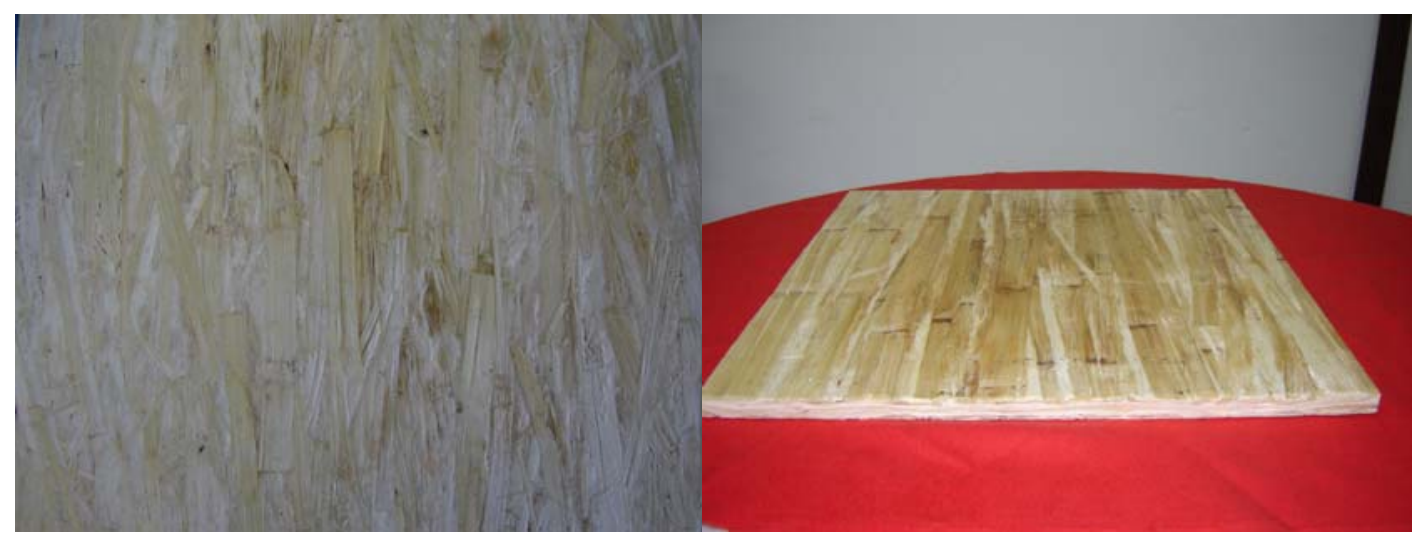

Figura 10.9. Painéis fabricados com vista arquitetônica

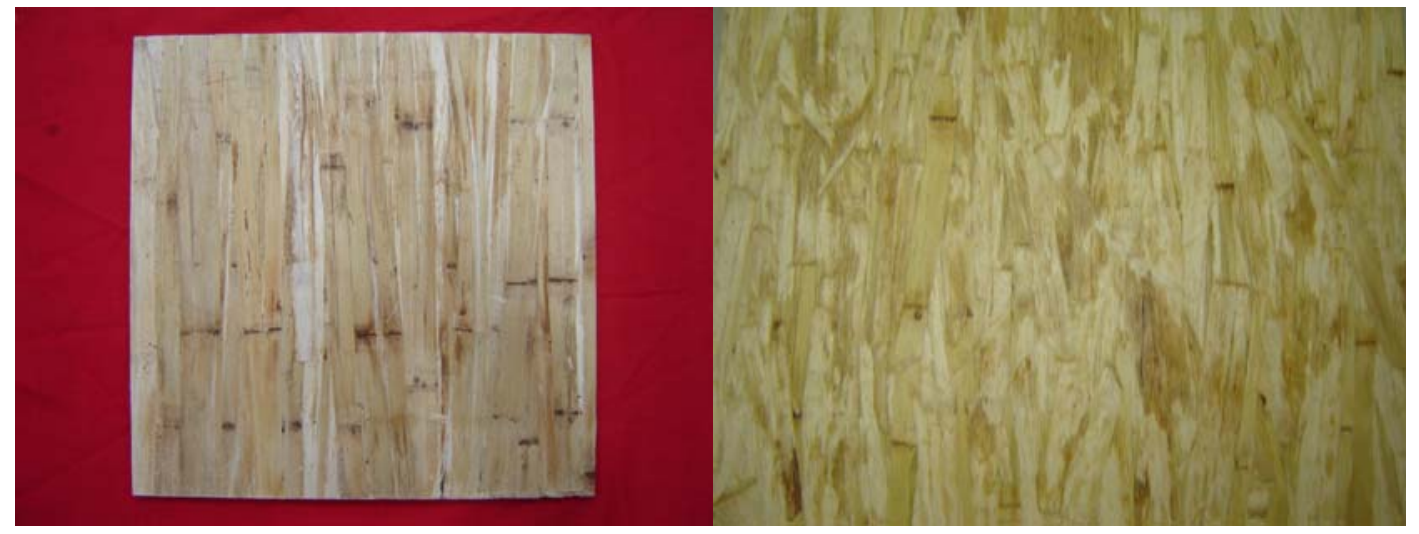

Figura 10.10 . Painéis prensados em uma temperatura de $90^{\circ} \mathrm{C}$ e a direita a $130^{\circ} \mathrm{C}$

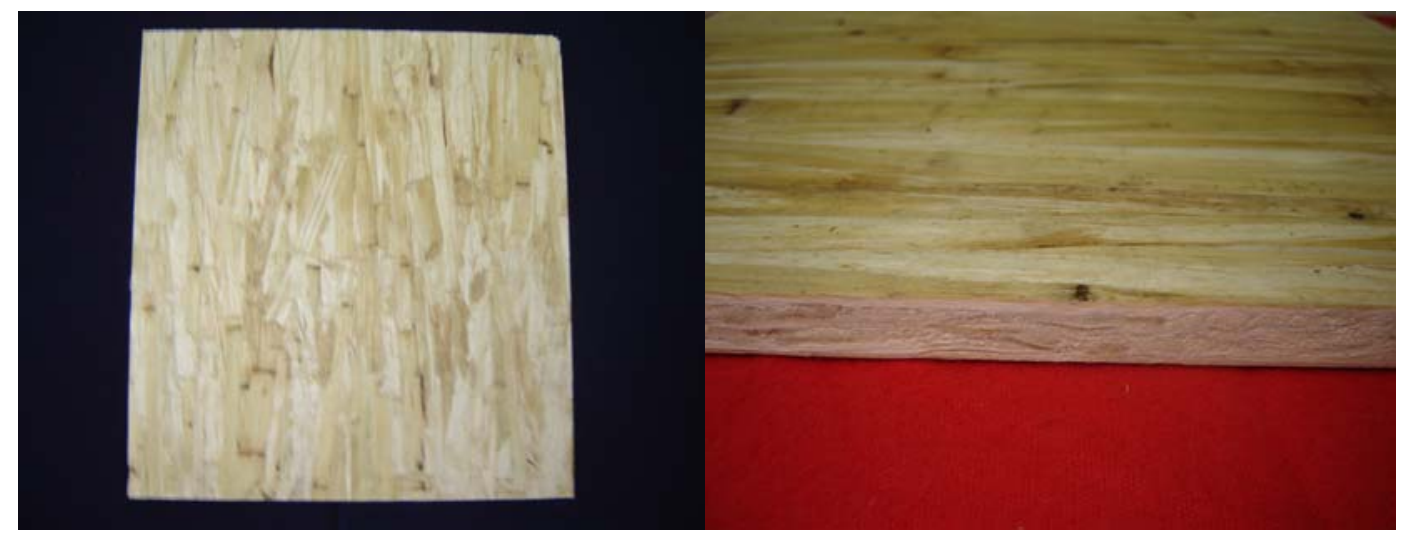

Figura 10.11. Vista de topo e lateral do painel de partículas longas de bagaço de cana 


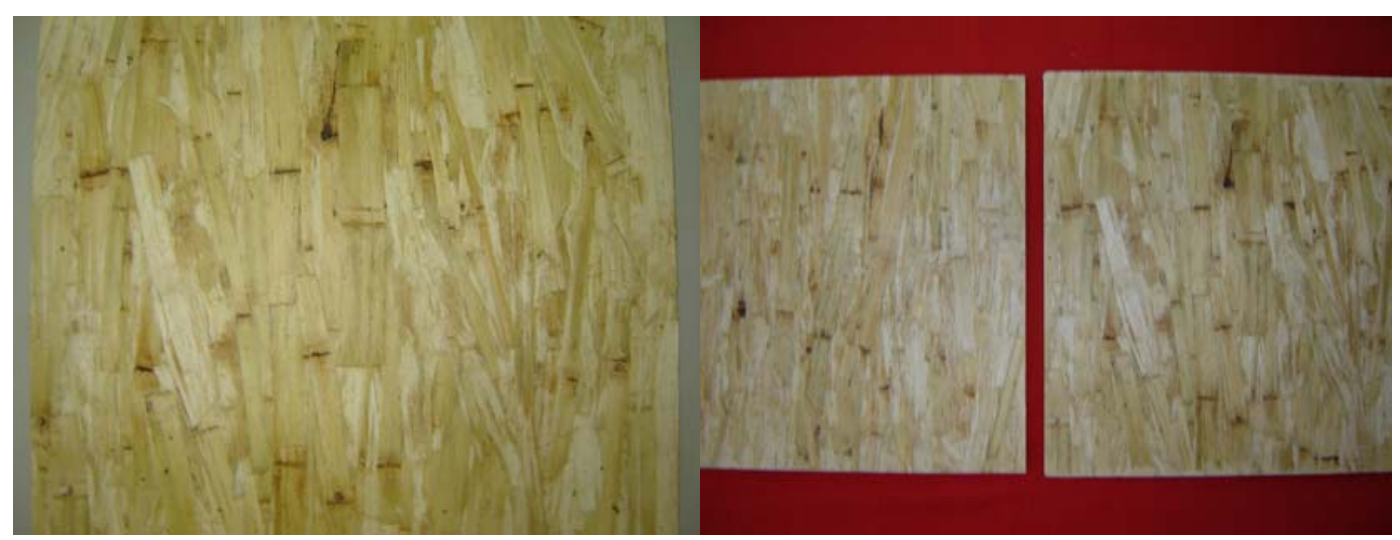

Figura 10.12. Painel a $130^{\circ}$ e confeccionados com resina a base de mamona e a direita, com resina a base de Cascomel M 08 ME

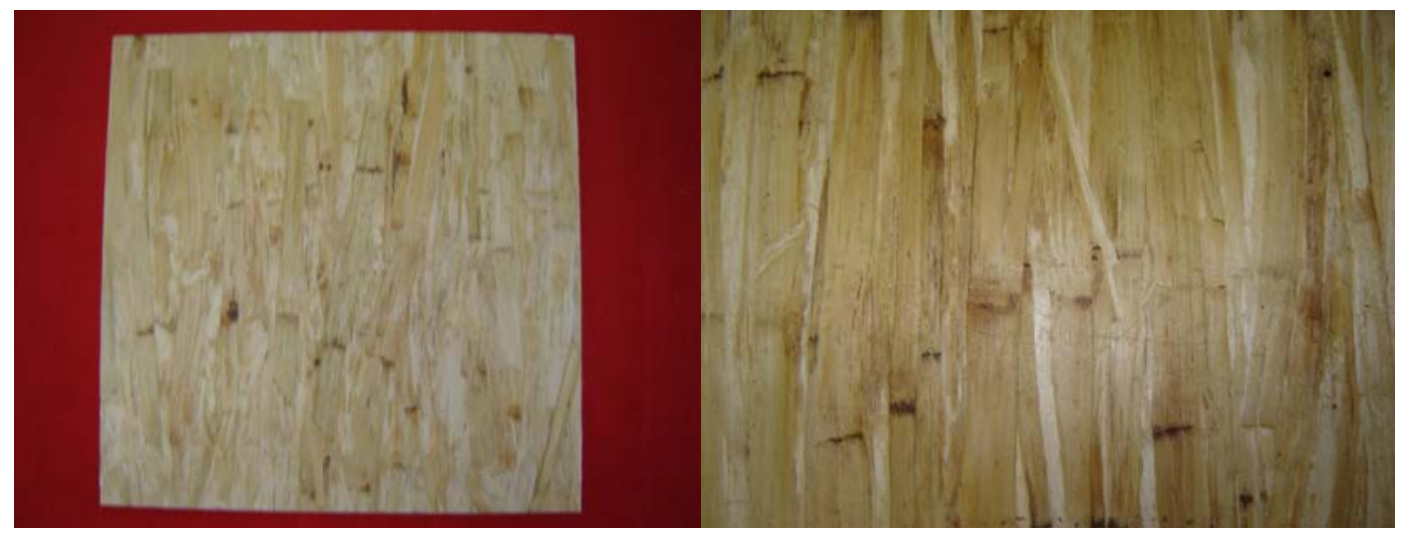

Figura 10.13 . Painéis a $130^{\circ} \mathrm{C}$

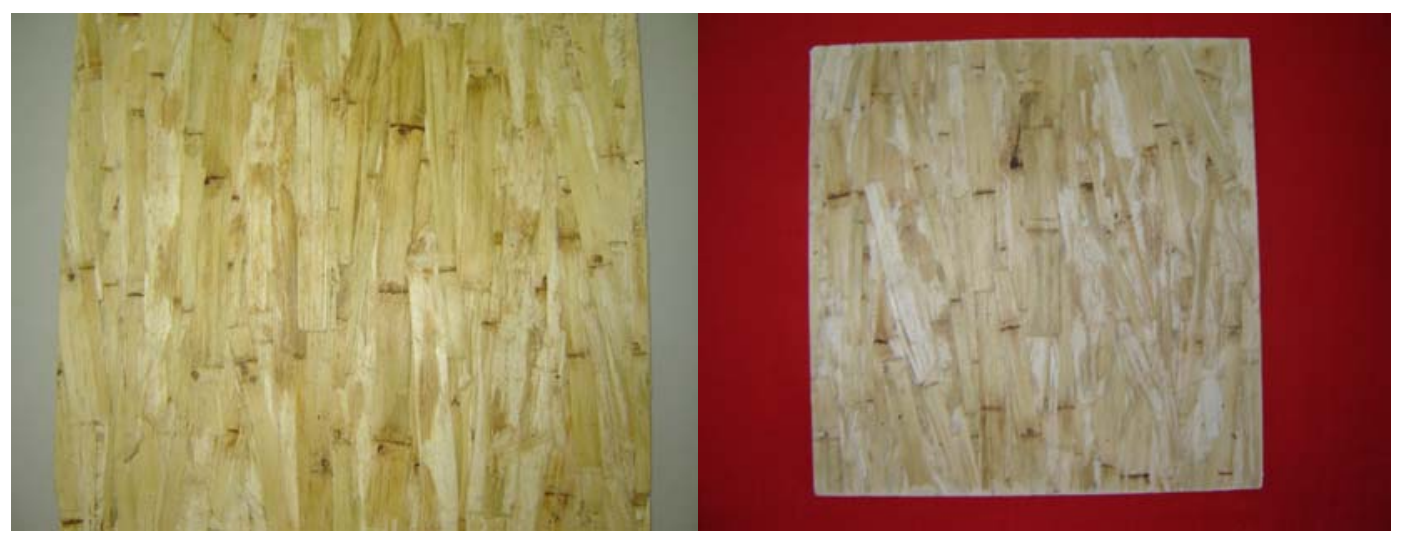

Figura 10.14 . Painéis prensados a $130^{\circ} \mathrm{C}$ e a $90^{\circ} \mathrm{C}$ 


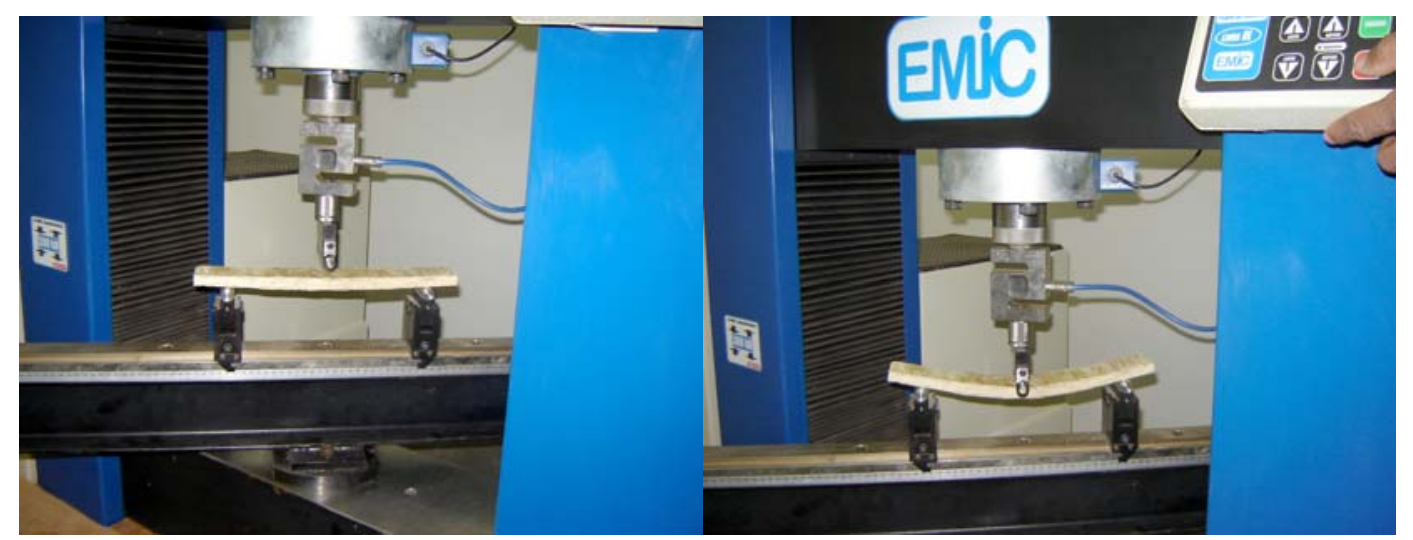

Figura 10.15. Inicio do ensaio de resistência à flexão na direção transversal as partículas longas

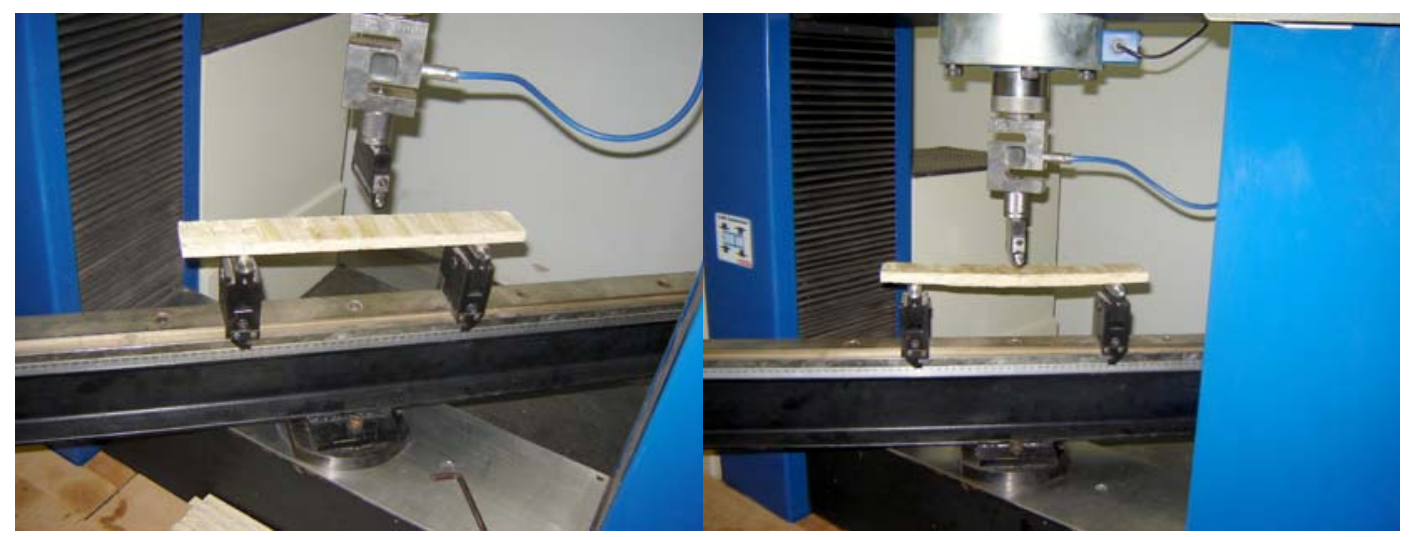

Figura 10.16. Término do ensaio de resistência à flexão na direção transversal as partículas longas

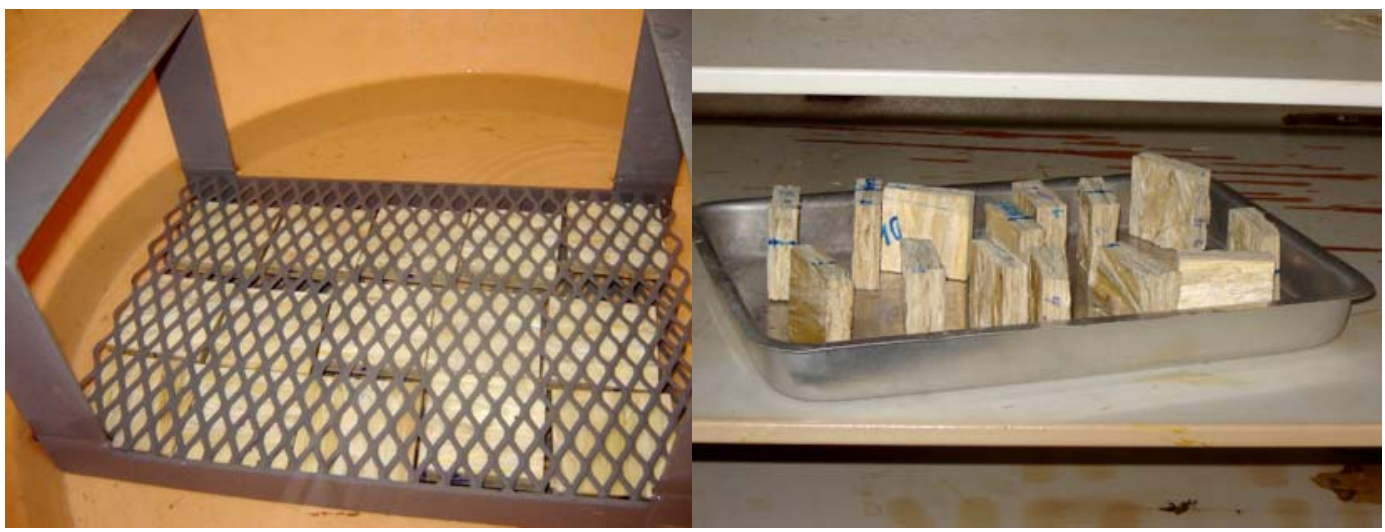

Figura 10.17. Corpos-de-prova submetidos ao ensaio de inchamento em espessura e secagem em estufa 


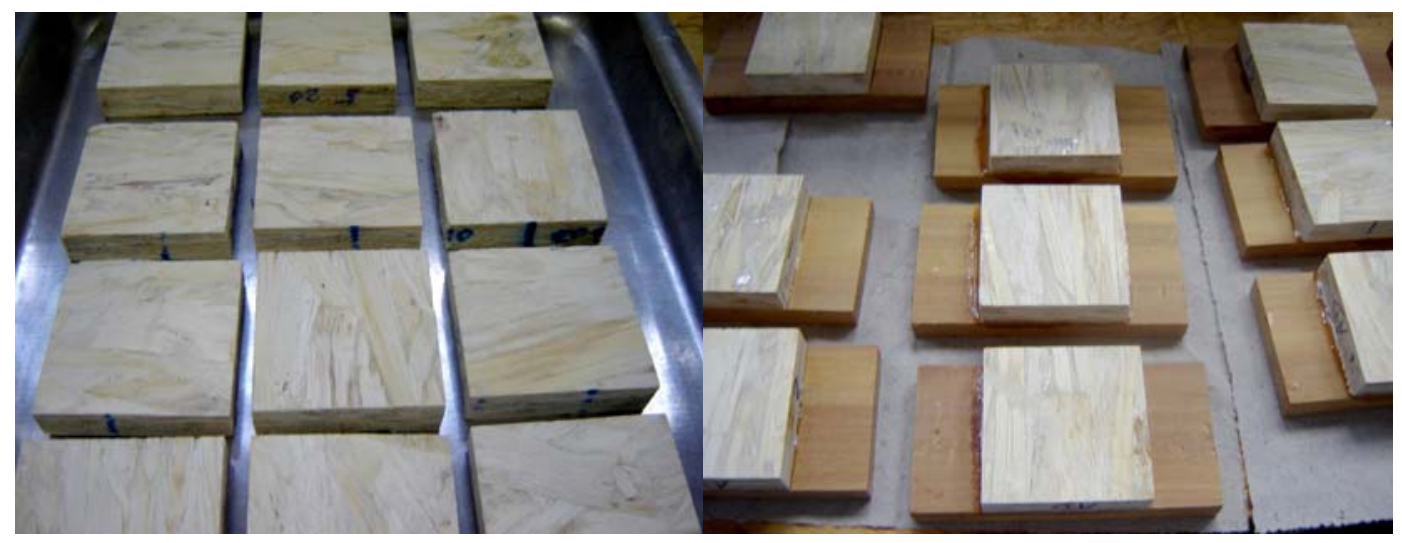

Figura 10.18. Corpos-de-prova lixados e sendo preparados para ensaios de acordo com norma EN 300/2002

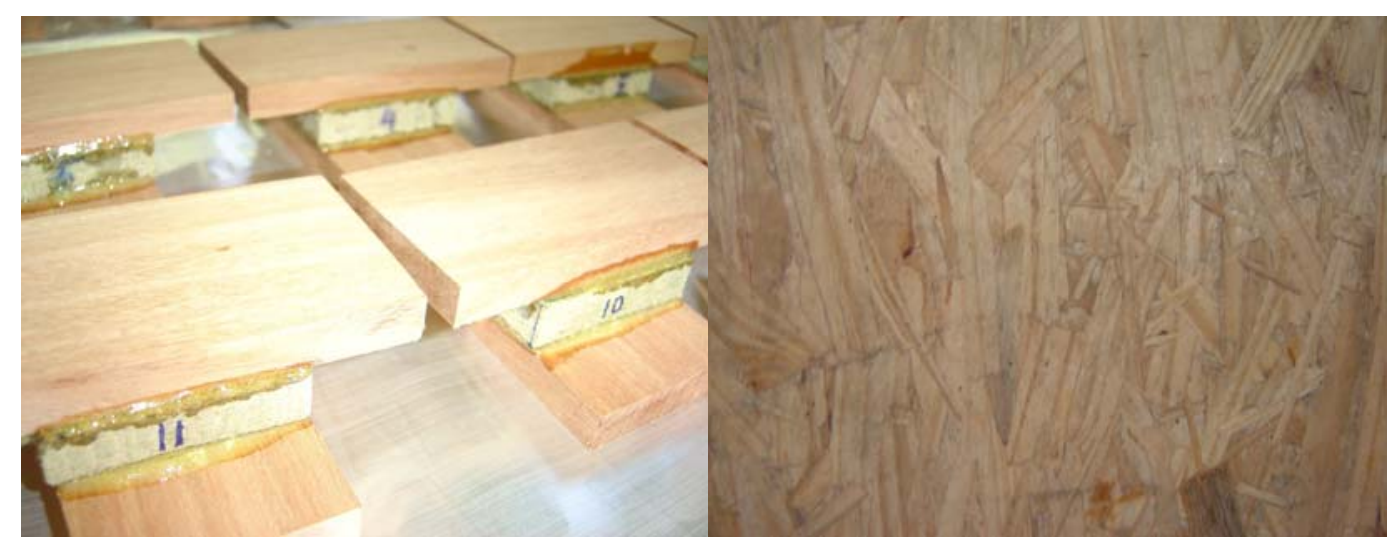

Figura 10.19. Corpos-de-prova prontos para ensaio de adesão interna e painel OSB de fabrica

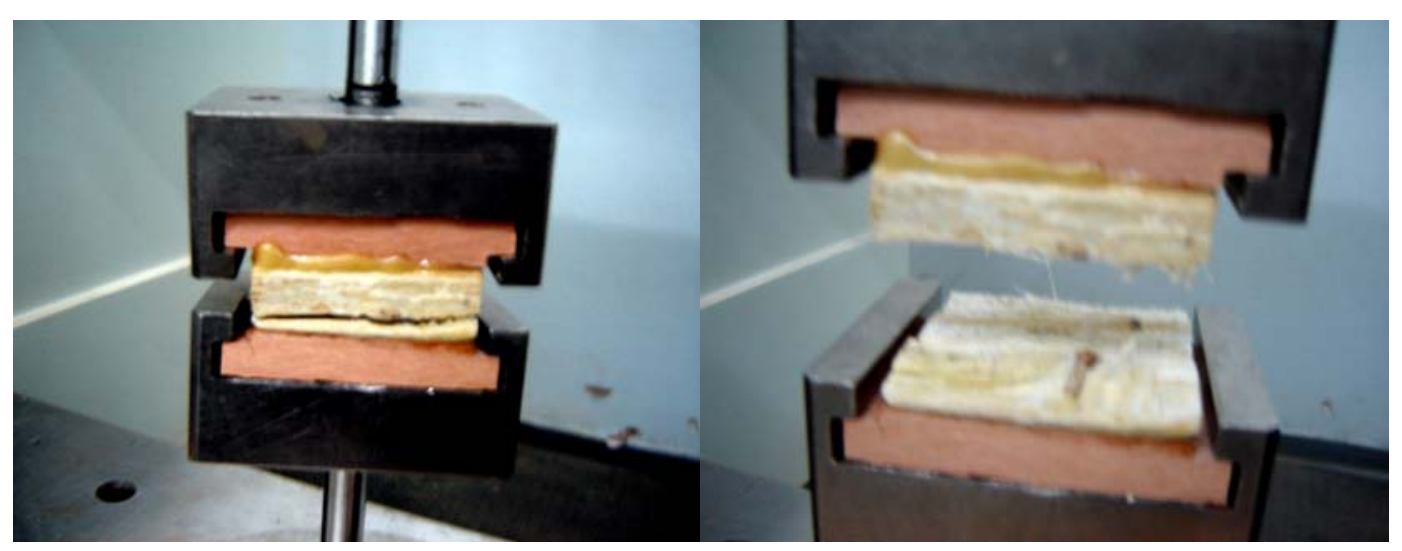

Figura 10.20. Ensaio de adesão interna com inicio de rompimento e a direita rompido 


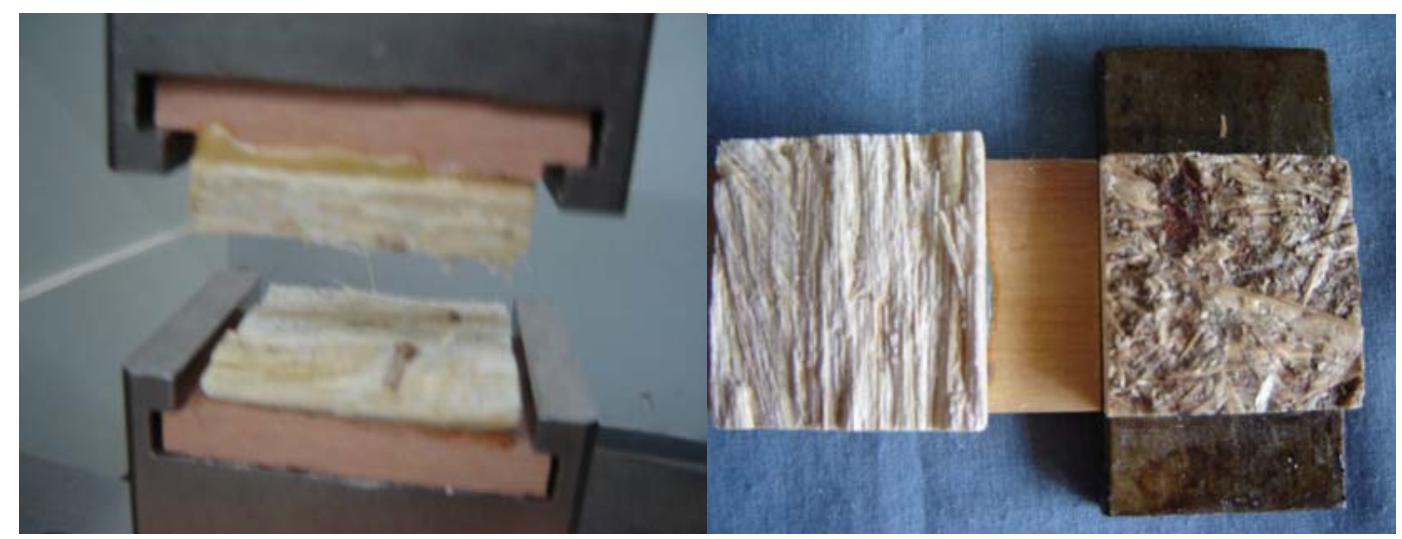

Figura 10.21. Visualizando face interna de corpos-de-prova de compósito de bagaço de cana de painéis rompidos por adesão interna, comparando com OSB de mercado

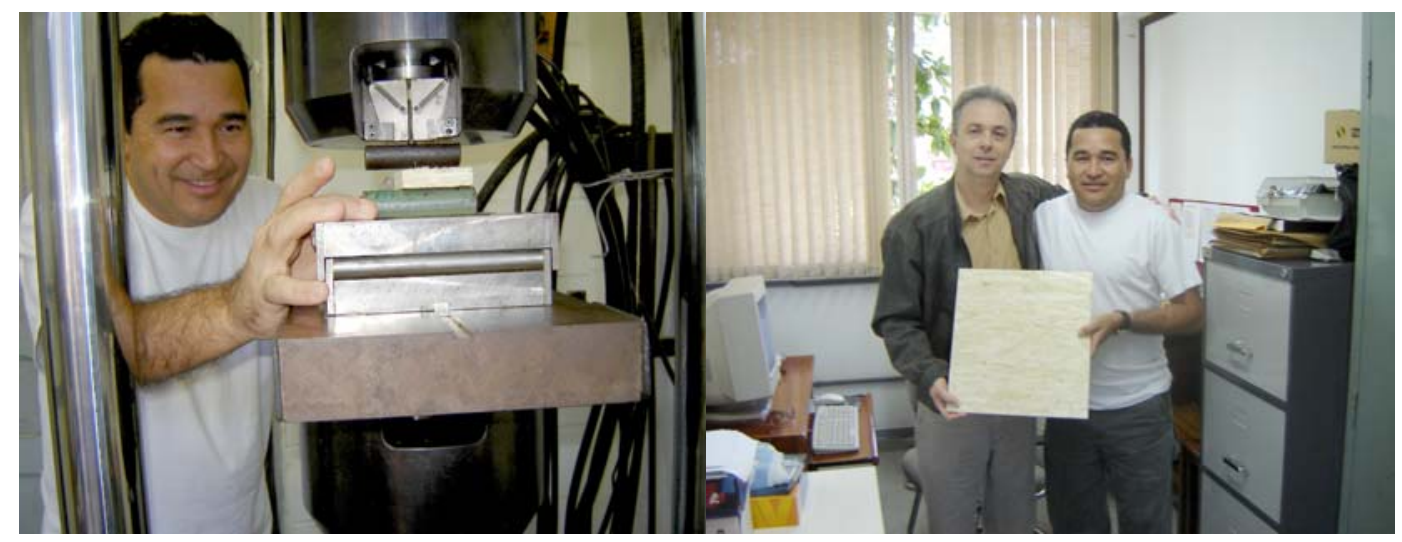

Figura 10.22. Preparando corpo-de-prova para ensaio e a direita painel de partículas longas de bagaço de cana-de-açúcar definitivo 


\section{APÊNDICE}




\title{
ALTERNATIVA DE EQUIPAMENTOS PARA FABRICAR PAINEL DE PARTICULAS LONGAS EM ESCALA DE LABORATÓRIO
}

\author{
Antonio Jorge Parga da Silva ${ }^{* *}$ e Francisco Antonio Rocco Lahr ${ }^{*}$ \\ ajparga@sc.usp.br e frocco@sc.usp.br \\ Instituições: * Universidade de São Paulo/EESC, São Carlos, SP; ${ }^{* *}$ Universidade de São Paulo/EESC, \\ São Carlos, SP \& CEFET-MA)
}

\section{INTRODUÇÃO}

A fabricação de OSB ( Oriented Strand Board ) em escala industrial requer equipamentos de alta produção e custo elevado. Em laboratórios, há necessidade de pesquisa em baixa escala de produção com mesmos padrões de escala industrial e relação custo/produção acessível. Os orientadores de partículas longas (ou lascas) e os misturadores são exemplos de equipamentos que podem ser adaptáveis, pois seu volume

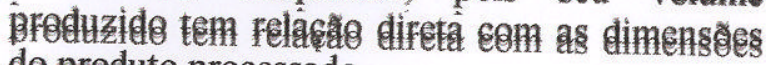
do produto processado.

ZHOW (1990) afirma que a orientação das partículas causa um aumento de 40 a $50 \%$ no MOR e MOE, respectivamente, no sentido paralelo à orientação em relação aos painéis de partículas distribuídas aleatoriamente.

SOBRAL FILHO (1979) ressalva que a largura das partículas também tem sido um parâmetro de estudo. Entretanto, parece que sua influência não é tão significativa como o comprimento e a espessura.

\section{OBJETIVOS}

Projetar ao nível de laboratório um controlador estático de pressão hidrostática para ensaios de inchamento em espessura, um misturador de partículas longas e um orientador de partículas.

\section{PROCEDIMENTO EXPERIMENTAL}

O misturador de partículas longas visa otimizar a produção de compósito orientado (OSB), aumentando o efeito de impregnação na relação partículas/resina.

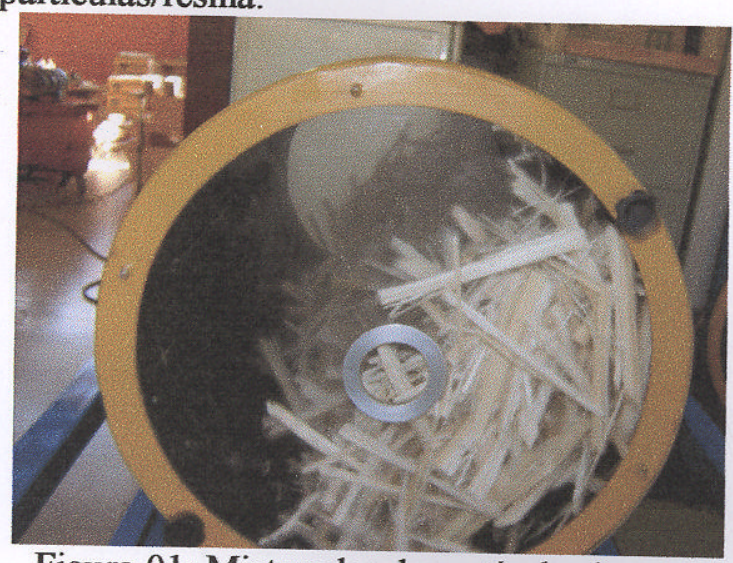

Figura 01: Misturador de partículas longas.
A aquisição e desenvolvimento de um orientador de partícula longa são devido a necessidade de redução de espaço e tempo de processo na fabricação de placas OSB em laboratório. 0 equipamento foi construído em aço e revertido com teflon, para evitar aderência da resina ao equipamento.

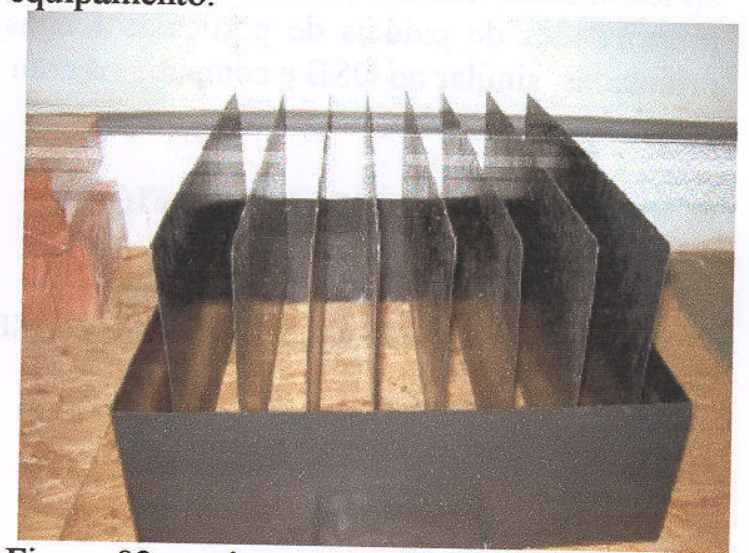

Figura 02: equipamento orientador de partículas para OSB em laboratório.

O controlador hidrostático projetado tem a função de evitar variações nos resultados estatísticos de todos os materiais submetidos a ensaio de absorção em água e inchamento em espessura, não deixando que corpos de provas tenham comportamentos de aleatoriedade e fixando todos a uma mesma coluna de pressão hidrostática, cujo objetivo é diminuir as variáveis de degradação na imersão.

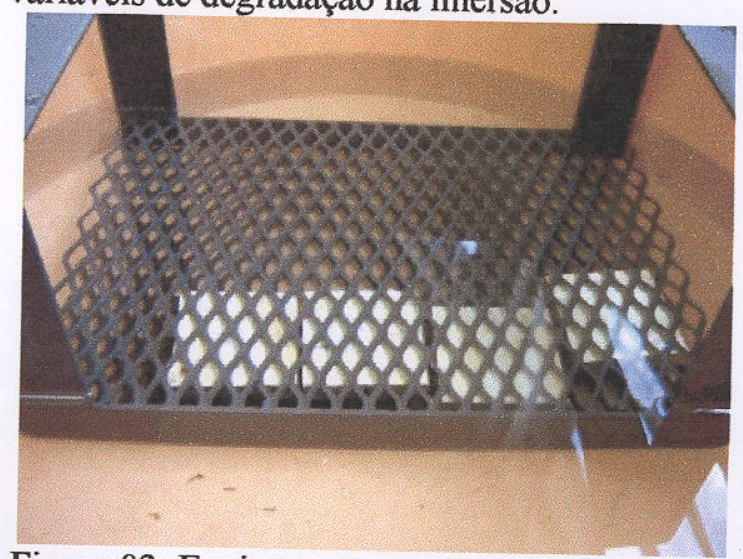

Figura 03: Equipamento controlador de pressão hidrostática. 


\section{RESULTADOS E DISCUSSÕES}

Para o misturador de partículas, os resultados com esta aplicação, mostrou-se favorável para adesão interna. Com relação ao orientador de partículas, facilitou-se o processo de confecção de chapas de partículas longas, com menor tempo de aplicação.

Para o controlador hidrostático, verificou-se uma melhor ajustagem dos ensaios de inchamento em espessura por 24 horas, eliminando eventuais problemas de coluna de liquido diferente para os corpos-de-prova.

\section{CONCLUSÕES}

Demonstrou-se aprovado e viável o uso destes equipamentos em laboratório, comparando sua aplicabilidade, custo e resultados em termos de propriedades de painéis de partículas longas e orientadas, similar ao OSB e compatíveis com as produzidas em escala industrial.

\section{REFERÊNCIAS BIBLIOGRÁFICAS}

Norma Europeia EN-300. Aglomerado de partículas de madeira longas e orientadas (OSB):
Definições, classificações e especificações, p. 127, Portugal (2002).

SOBRAL FILHO, M. Influence of wood furnish type on properties of oriented strand panels. Forest Products Journal, Madison, v.31, n. 9, p. 43-52. 1981.

ZHOW, D. A estudy of oriented structural board made from hybrid poplar. Phisical and mechanical properties of OSB. Holz Als Roh Und Werkstoff, volumen 48, número 7-8, 293296, Berlin (1990).

\section{AGRADECIMENTOS}

A minha instituição CEFET-MA; A USP/EESC/IFSC/IQSC; Aos FAPEMA, CNPq e CAPES. 